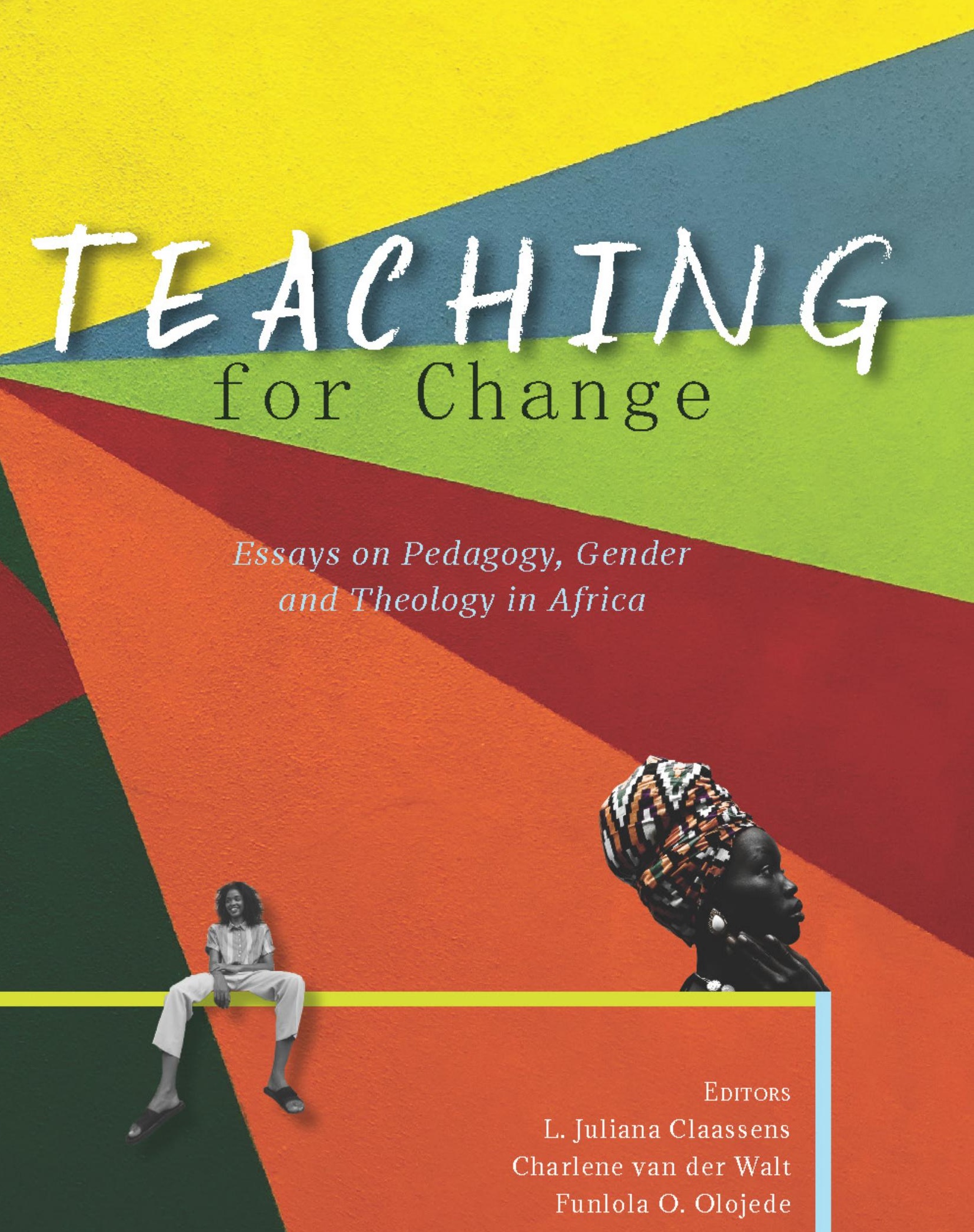




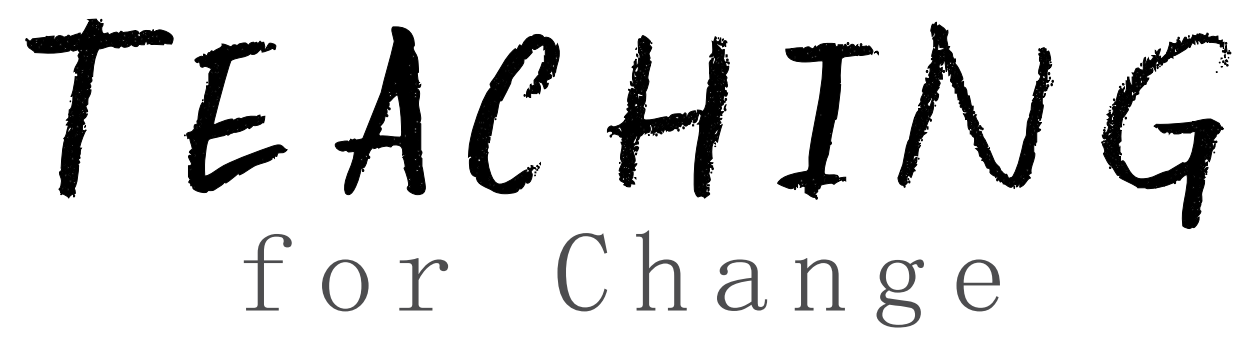

Essays on Pedagogy, Gender and Theology in Africa

EDITORS

L. Juliana Claassens

Charlene van der Walt

Funlola O. Olojede

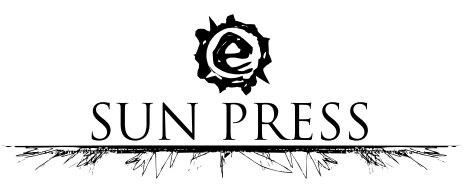




\section{Teaching for Change: Essays on Pedagogy, Gender and Theology in Africa}

Published by AFRICAN SUN MeDIA under the SUN PReSS imprint

All rights reserved

Copyright (C) 2019 AFRICAN SUN MeDIA and the editors

This publication was subjected to an independent double-blind peer evaluation by the publisher.

The editors and the publisher have made every effort to obtain permission for and acknowledge the use of copyrighted material. Refer all enquiries to the publisher.

No part of this book may be reproduced or transmitted in any form or by any electronic, photographic or mechanical means, including photocopying and recording on record, tape or laser disk, on microfilm, via the Internet, by e-mail, or by any other information storage and retrieval system, without prior written permission by the publisher.

Views reflected in this publication are not necessarily those of the publisher.

First edition 2019

ISBN 978-1-928480-12-9

ISBN 978-1-928480-13-6 (e-book)

https://doi.org/10.18820/9781928480136

Set in Warnock Pro Light 10/14.5

Cover design, typesetting and production by AFRICAN SUN MeDIA

SUN PReSS is a licensed imprint of AFRICAN SUN MeDIA. Scholarly, professional and reference works are published under this imprint in print and electronic format.

This publication can be ordered directly from:

www.sun-e-shop.co.za

www.store.it.si (e-books)

africansunmedia.snapplify.com (e-books)

www.africansunmedia.co.za 


\section{TABLE OF CONTENTS}

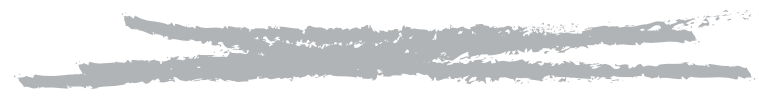

Introduction

L. Juliana Claassens, Charlene van der Walt \& Funlola O. Olojede

\section{Storytelling and Transformation}

Moral Imagination: Stories That Inspire a Quest for Change

Pumla Gobodo-Madikizela

The Case of the Trafficked Princesses (Jer 40-44): Trauma Hermeneutics as Pedagogical Tool for Teaching on Gender-Based Violence

L. Juliana Claassens

The Rape of The Levite's Concubine and Karoo Moose:

Pedagogical Tools in Transforming a Rape Culture

Renate van der Westhuizen (with L. Juliana Claassens)

Through an Immigrant's Eyes: Effects of Migration on Women and

Children in the Light of Migration Stories in Genesis 12-50

Funlola O. Olojede

\section{Sexual Diversity and Encounter}

Deploying Indecent Literary and Socio-Historical Detail for Change:

Genesis 2:18-24 as a Resource for Choice of Sexual Partner

Gerald $\mathrm{O}$. West

Having Difficult Conversations: Engaging Film as a Reflective Surface to Encourage Dynamic Intersectional Encounters

Charlene van der Walt

Co-Creating Transformative Spaces through Dialogue: Inclusive and Affirming Ministries' Partnership with the Faculty of Theology, Stellenbosch University

Michele Boonzaaier \& Charlene van der Walt

Reimagining Sin? Nurturing Youth Spiritualities for Social Justice 


\section{Towards Transformative Social Action}

Pushing Boundaries Toward Transformation Through the Political

Theology of Dorothee Soelle and Denise Ackermann

Tanya van $W y k$

HIV and Faith: Shaping the Response from Rhetoric into Transformative

Social Action

Beverley Haddad

The Colour of Change: Identity Matters, Christian Faith and Resistance

in the HIV and AIDS Pandemic

Cheryl B. Anderson

Conflict in Conflict: Mobilising Against Violence Against Women and Girls

in Local Faith Communities in Areas Affected by Armed Conflict

Elisabet le Roux

List of Contributors 


\section{INTRODUCTION}

\section{"Education is the most powerful weapon which you can use to change the world" \\ - Nelson Mandela}

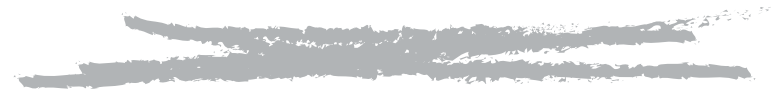

Teaching for Change. The title of this collection of essays, which highlights the various ways in which we individually and collectively address discourses, traditions and practices that explore the intersection of gender and theology in our respective contexts, reveals our belief in the power of education as a tool of transformation. Many of the contributors to this volume work in theological higher education institutions in different parts of South Africa with one colleague coming all the way from the United States. One colleague at Stellenbosch University heads up the Unit for Historical Trauma and Transformation. Others work in the NGO and FBO sectors, while one contributor is the Head of a school. All of us are concerned about the ongoing instances of sexism, racism and homophobia that continue to plague our country and often erupt in various forms of abuse, discrimination and violence. And all of us are passionate about raising awareness, and changing the way people think and feel and act regarding the intersections of race, class, sexual orientation, health, and the various other signifiers that are responsible for ongoing forms of injustice and violation. Within this commitment to effect change, we in this volume have come together to reflect on the best pedagogical practices of how to teach on often complex issues of gender, sexual orientation, race, class and how they impact health in our classrooms, in our churches, in the communities where we live and work.

This ongoing project of contemplating the best ways to teach on Gender, Health and Theology in our (South) African context is closely associated with the work we have done at Stellenbosch University in terms of the MTh Gender and Health programme that was developed with generous support from the Church of Sweden in collaboration with the Swedish Government Development Agency (SIDA). The aim of the MTh Gender and Health was to identify students from various communities across South Africa and beyond its borders who are positioned in such a way as to be able to serve as "thought leaders" and "change agents" ${ }^{1}$ when it comes to the harmful effects of racism and sexism, the exclusivist practices of Bible interpretation, HIV and AIDS, gender-based violence, sexual reproductive health and rights, toxic constructions of masculinity, heteronormativity and sexual diversity. 
Since 2013, the MTh Gender and Health has equipped these current and potential change agents with nuanced vocabulary and theoretical tools to enable them to function even more dynamically within their respective contexts after graduation. At Stellenbosch, the MTh Gender and Health drew a rich student population that included pastors, teachers, pastoral counsellors, church leaders, NGO practitioners, lawyers, youth group leaders and those committed to academic endeavours. Beyond engaging theoretically with these issues, however, the insistence within this MTh Gender and Health has constantly been to engage with embodied contextual realities; to sit with those most affected; to listen to those most vulnerable; and to begin all inquiry from this place.

Another exciting moment in this journey of exploring the intersection of Gender, Health and Theology was evident in the Cultivating Change Agents Conference held in March 2017 at which occasion many of the contributors to this volume presented their work. This conference coincided with the official launch of the Gender Unit under the directorship of Prof. Juliana Claassens of the Theology Faculty. The aim of the Gender Unit is to build on the initial work and insights gained within the praxis of the MTh Gender and Health and to extend the reach of the programme by creating more comprehensive interdisciplinary spaces for theoretical reflections, enhance engagement and collaboration with local contextual partners and develop research and scholarship that continue to transform the African landscape at the intersection of Gender, Health and Theology.

Within this collective, ongoing journey to find the best possible means of teaching on the intersection of Gender, Health and Theology in our respective contexts, the following three methodological points are worth mentioning that in some way or another inform the work of the various essays in this volume. First, many of the essays in Teaching for Change in some way are rooted in what has been described as intersectionality. In her article, "Intersectionality as Buzzword", Kathy Davis considers why this particular manifestation of feminist theory has been so successful in shaping discourses in recent years. She writes: "[Intersectionality] encourages complexity, stimulates creativity, and avoids premature closure, tantalizing feminist scholars to raise new questions and explore uncharted territory."

'Intersectionality' is a term coined by Kimberly Crenshaw in 1989 to capture the "interaction between gender, race, and other categories of difference in individual lives, social practices, institutional arrangements, and cultural ideologies". ${ }^{3}$ Davis notes that even though Crenshaw's notion of intersectionality addressed an age-old problem of moving beyond feminist concerns as only pertaining to white middle-class Western women, in order to take seriously women's experience of race, class and social location what is important is that intersectionality did so "with a new twist", bringing together critical feminist theory pertaining to race, class and gender, and the insights yielded by postmodern feminist theory. ${ }^{4}$ 
Probably one of the most promising aspects of the notion of intersectionality is its ability to "think [...] across categories". ${ }^{5}$ It is the realisation that various factors such as gender, race, class, but also sexual orientation, age, health, religion, geographical location and education, shape individuals' and communities' lives in unique ways. ${ }^{6}$ Actually the question of which categories to include and "when to stop" serves as the source of creative energy. Davis describes as follows the value of these "endless constellations of intersecting lines of difference to be explored":

With each new intersection, new connections emerge and previously hidden exclusions come to light. The feminist scholar merely needs to 'ask (an)other question,' and her research will take on a new and often surprising turn. She can begin to tease out the linkages between additional categories, explore the consequences for relations of power, and of course, decide when another 'question' is needed or when it is time to stop and why. ${ }^{8}$

To a certain extent, this current collection of essays signifies a collective attempt at reflecting on the value of intersectionality for the study of Gender, Health and Theology. It is a moment of reflection on the values that inform our scholarly activity and their impact on our pedagogical praxis; a moment of evaluation regarding the embodied and contextual implications for communities most vulnerable in the intersection of Gender, Health and Theology that is central to our research activity and a moment to ask ourselves serious questions about the implications of our theory of change aimed at developing and nurturing change agents within a range of communities and contexts. ${ }^{9}$

Second, many of the contributions are rooted in the understanding of the important role of stories in the form of narrative texts (both biblical and secular) and films in order to create the space for moral reflection. In this regard, Martha Nussbaum has led the way in making a case for the role of literature and art to effect change, to cultivate emotions, to help bridge distance between individuals and groups. In this regard, she writes extensively in her book, Upheavals of Thought, about the ability of "works of art [to] promote compassion in their audience by inviting both empathy and the judgment of similar possibilities" ${ }^{10}$

For instance, citing the example of the children's book, Black Beauty, and the classic American novel, Uncle Tom's Cabin, Nussbaum reflects on the role of literature in her own journey of growing in empathy for the way horses are treated, in addition to the shocking reality of slavery in the American South. She writes as follows about the ability of stories to, as she puts it, "embrace the lives of others": ${ }^{11}$

To promote empathy across specific social barriers, we need to turn to works of art that present these barriers and their meaning in a highly concrete way ... In that way, it exercises the muscles of the imagination, making people capable of inhabiting for a time, the world of a different person, and seeing the meaning of events in that world from the outsider's viewpoint. ${ }^{12}$

Nussbaum points in particular to the values of the genre of tragedies, or tragic narratives that could help individuals and groups transcend the narrow circle of concern that is typical 
to being human, using "resources of poetry, music, and dance to make the characters' plight vivid and moving". As she writes, "A person who has been ejected from the characters' circle of concern is restored to it by the power of art."13

Third, important to many of the contributions in this collection of essays is the role of dialogue and encounter in effecting change. It is by entering the life world of those who are different from us that we are able to forge an empathetic connection. In the previous point, this encounter is said to occur in the form of narrative and film. However, probably even more significant are the encounters that take place in real time - in contextual bible studies; in classrooms; in churches; in communities. In all of these settings, dialogue, and more specifically, hearing the other's voice are vital for effecting change. Nussbaum, for instance, reflects on the valuable role of book clubs in order to "promote a type of emotional experience and exchange that is cooler and more deliberative than the experience of watching a movie or visiting a memorial". ${ }^{14}$ As she explains, "Critical conversation and emotional participation join hands in a valuable way." 15

This focus on dialogue and conversation is central to the theology done in context as evident in the work of the Ujamaa Centre, represented in this volume by the exciting new Contextual Bible Study on sexual diversity that Gerald West is developing. Dialogue is also central to the mission of one of our NGO partners, Inclusive and Affirming Ministries (IAM), as outlined by Michelle Boonzaaier together with Charlene van der Walt, specifically as it pertains to their involvement with the MDiv Programme at the Faculty of Theology at Stellenbosch University. And dialogue underlies also the work of the two members of the Unit for Religion and Development Research at Stellenbosch University when Selina Palm and Elisabet le Roux enter various communities and document community members' experiences of difficult topics such as violence against women and girls, and teenagers' views regarding sexual diversity.

This collection of essays on pedagogy, gender and theology in Africa in Teaching for Change consists of three sections. In the first section, "Storytelling and Transformation", Prof. Pumla Gobodo-Madikizela from the Unit for Historical Trauma and Transformation at Stellenbosch University, by means of three poignant stories, shows that the notion of "empathic repair" could be applied to capture the transformation and potential necessary to build healing communities in deeply divided societies that have emerged from violent conflict. Employing the power of biblical narratives to teach on gender-based violence, Juliana Claassens rereads the story of the Trafficked Princesses in Jeremiah 40-44 through a lens of trauma hermeneutics, showing how this ancient story draws our attention to the plight of the many migrant women in our local and global context today. Renate van der Westhuizen (with Juliana Claassens) also reads the story of the rape of the Levite's concubine in Judges 19 in the light of the South African film, Karoo Moose, and argues 
that such a reading could serve as a pedagogical tool in transforming the culture of rape in South African schools. And, in the last essay in that section, Funlola Olojede rereads the stories of migration in Genesis 12-50 from the perspective of a female immigrant to show that the effects of migration on women and children in the biblical narratives have contemporary and pedagogical relevance.

In the second section of Teaching for Change, "Sexual Diversity and Encounter", Charlene van der Walt reflects on her experience of using the medium of film in the MTh Gender and Health at Stellenbosch University, thus contemplating the pedagogical practice of raising difficult conversations on sexual diversity by watching the quite challenging film, Skoonheid, together. Gerald West also initiates some difficult conversations of his own through a proposed Contextual Bible Study on Genesis 2, which he develops by means of the exegetical and hermeneutical tools afforded by Queer Biblical Interpretation. In their contribution, Michelle Boonzaaier and Charlene van der Walt reflect on the importance of encounter and dialogue in teaching seminary students how to initiate conversations on sexual diversity. And in her essay on "Reimagining Sin?" Selina Palm, based upon interviews with youth members of the Rondebosch United Church, Cape Town, proposes that "to creatively reimagin[e] sin may help local churches to cultivate change agents around contemporary intersectional oppressions including those around gender and sexuality".

In the final section of Teaching for Change, "Towards Transformative Social Action", Tanya van Wyk argues that the political theology of Dorothee Soelle and Denise Ackermann that respectively employs the genre of poetry and letters can be employed to push boundaries in order to foster transformative social action. Focusing on the topic of HIV/AIDS and the curriculum, Beverley Haddad seeks to document the strategies implemented within the School of Religion and Theology (now School of Religion, Philosophy and Classics) at the University of KwaZulu-Natal "to bring about a shift from moralistic rhetoric to transformative social action within the faith community". Cheryl Anderson, who investigates the Christian response to the HIV/AIDS pandemic in both South Africa and her own context of the United States, proposes that given the fact that those who are affected are disproportionately black, "change does indeed have a colour and any prevention strategies should take the realities of black people into account". And finally, Elisabet le Roux reports the findings of a study in which members of a local faith community in areas affected by armed conflict in the Democratic Republic of the Congo were trained to mobilise against gender-based violence in their communities.

This collection of essays in Teaching for Change reflects a significant moment in the life of the interpretative community gathered around a shared concern of how best to teach on the intersection of gender, health, and theology in our (South) African context. The last word on this topic is not spoken - it remains an ongoing, open-ended conversation. 
However, as contributors, it has been a privilege to be part of this dialogue, and as editors, we have been deeply enriched by the passion, commitment, and knowledge expressed in this volume. Aluta continua!

\author{
L. Juliana Claassens \\ Faculty of Theology \\ Stellenbosch University
}

\section{Charlene van der Walt}

School of Religion, Philosophy and Classics

University of KwaZulu-Natal

\section{Funlola O. Olojede}

Faculty of Theology

Stellenbosch University

\section{Bibliography}

Davis, Kathy. "Intersectionality as Buzzword: A Sociology of Science Perspective on what Makes a Feminist Theory Successful." Feminist Theory 9/1 (2008): 67-85. https://doi.org/10.1177/1464700108086364

McCall, Leslie. "The Complexity of Intersectionality," Signs 30/3 (2005): 1771-1800. https://doi.org/10.10 $86 / 426800$

Nussbaum, Martha. Political Emotions. Why Love Matters for Justice. Cambridge, MA: The Belknap Press of Harvard University Press, 2013.

Nussbaum, Martha. Upheavals of Thought: The Intelligence of Emotions. Cambridge: Cambridge University Press, 2001. https://doi.org/10.1017/CBO9780511840715

Shields, Stephanie A. "Gender: An Intersectionality Perspective," Sex Roles 59/5 (2008): 309. https://doi.org/ 10.1007/s1 1199-008-9501-8

\section{Endnotes}

1 The term 'change agents', or 'agents of change', has typically been used in the Theory of Change that informed the MTh Gender and Health programme sponsored by the Church of Sweden. The reasoning behind this pedagogical principle is that students, who already are leaders in their respective communities, are equipped by further study to bring about change in their respective communities pertaining to harmful thoughts, perceptions and actions when it comes to the intersection of gender, health and theology.

2 Kathy Davis, "Intersectionality as Buzzword: A Sociology of Science Perspective on what Makes a Feminist Theory Successful." Feminist Theory 9/1 (2008): 79.

3 Davis, "Intersectionality as Buzzword," 68.

4 Davis, "Intersectionality as Buzzword," 73. Cf. also Leslie McCall, "The Complexity of Intersectionality," Signs 30/3 (2005): 1773.

5 Davis, "Intersectionality as Buzzword," 75. Scholars differ on whether intersectionality is a theory, a concept or heuristic device, or a reading strategy for doing feminist analysis. Nevertheless, despite these differences in conceptualisation, most scholars agree that intersectionality is vital for feminist theory; cf. Davis, "Intersectionality as Buzzword," 68.

6 Cf. McCall, who writes that "social life is considered too irreducibly complex" with too many "multiple and fluid determinations of both subjects and structures," to offer simple and simplistic explanations, "The Complexity of Intersectionality," 1773.

7 McCall demonstrates something of the complexity of identifying these categories. She writes: "If the category of class is incorporated into the analysis, then gender must be cross-classified with class which is composed (for simplicity) of three categories (working, middle and upper), thus creating six groups. If race-ethnicity is incorporated into the analysis, and it consists of only two groups, then the number of groups expand to twelve," "The Complexity of Intersectionality," 1786.

8 Davis, "Intersectionality as Buzzword," 77.

9 Stephanie A Shields, "Gender: An Intersectionality Perspective," Sex Roles 59/5 (2008): 309.

10 Martha Nussbaum, Upheavals of Thought: The Intelligence of Emotions (Cambridge: Cambridge University Press, 2001), 351.

11 Nussbaum, Upheavals of Thought, 353.

12 Nussbaum, Upheavals of Thought, 431.

13 Martha Nussbaum, Political Emotions: Why Love Matters for Justice (Cambridge, MA: Harvard University Press, 2013), 265.

14 Nussbaum, Political Emotions, 309.

15 Ibid. 



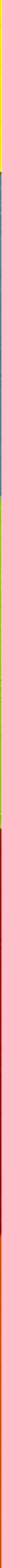




\section{MORAL IMAGINATION \\ Stories that Inspire a Quest for Change}

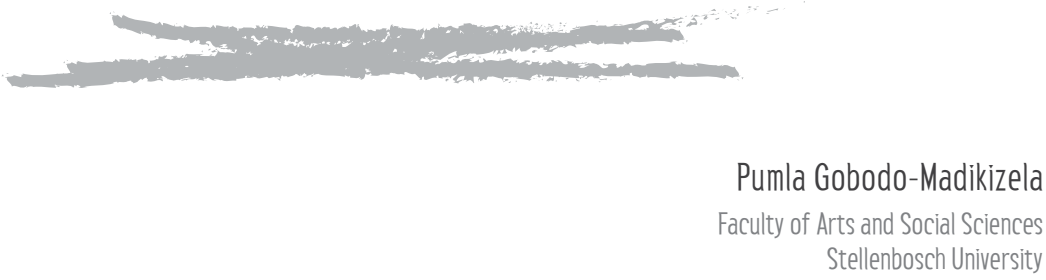

\section{Introduction}

In her memoir, Good Morning, Mr Mandela, Nelson Mandela's former private secretary Zelda La Grange ${ }^{1}$ recounts a scene that took place shortly after Nelson Mandela was inaugurated as South Africa's first democratically elected president. La Grange was working in parliament as a typist and was unexpectedly moved to the presidency to help prepare Nelson Mandela's schedules and related tasks. She approached her first encounter with Mandela with trepidation, not only because of being a nervous 23-year-old, but probably also because as a young Afrikaner she did not know how to relate to a man who in the collective consciousness of most Afrikaners - and perhaps most crucially in their collective unconscious - was still a "terrorist" who evoked fear and mistrust in them. Her fears and uncertainty were quickly replaced with tears when Mandela greeted her warmly and spoke to her in Afrikaans. Hearing him speak to her in her language, she broke down and cried. And as she wept - tears of shame, she tells readers in her memoir - Mandela comforted her. She left his office feeling calmer. La Grange writes about this encounter as a "turning point" moment that led her on a journey of self-reflection on her fervent racism, which eventually brought her onto a path of change and transformation. La Grange later served as Mandela's loyal and most trusted private secretary, from his years as president and throughout his retirement and illness for 19 years until his passing.

Nelson Mandela was a master of the art of creating opportunities for reflection and change in those he encountered, particularly his encounters with former enemies both during his years in prison and after he came out of prison to lead South Africans towards the vision of freedom and democracy. "No one is born hating another person because of the colour of his skin, or his background, or his religion." This is one of his many important lessons. "People must learn to hate," he said, "and if they can learn to hate, they can be taught to love, for love comes more naturally to the human heart than its opposite." 
For Mandela, these were not just words - philosophical statements thrown around during moments of public appearances. He embodied this ethical consciousness. It was a principled commitment to an ethic of care based on values with foundations within a framework of relational responsibility - responsibility for the other. Such a framework requires commitment to a stance of moral imagination, to a certain intentional openness to the possibility of reaching out beyond the self and towards the other.

Nelson Mandela's name has become a symbol of the possibility of this ethical vision of the self-transcendent position - a metaphor pointing to a more general horizon of an ethics of care and responsibility for the Other in the context of our "dealing with the past". He has blazed the trail for a new kind of citizenship that calls on us to act in ways that might create relational experiences that can help heal historical ruptures. One of the enduring lessons of Madiba's legacy is shining the light on the human capacity for moral imagination and understanding - the power of empathy, even empathy for one's former enemies.

The essence of empathy is the capacity to feel with and to participate in shared reflective engagement with the other's inner life. Most scholars recognise that some form of identification with the other at a deeper internal level is central to the capacity for empathy. Merleau-Ponty, for example, defines empathy as "the intertwining of our lives with those of others". ${ }^{3}$ For David Black, empathy involves a process of imagination. It is "a sophisticated act of the imagination, a 'trial identification' done by someone who is consciously relating to another's mental state".

An aspect of empathy that has received scant scholarly attention is care for the other that sometimes accompanies an empathic response. Caring goes beyond the "mirroring" described in neuroscientific understandings of empathy which present empathy as a feeling into the mental state of another person. The caring that I refer to here arises from the moment-by-moment negotiation of the intersubjective relationship between people, who are trying to forge links and to connect on a human level. It is an ongoing process of introspection and mutual reflection that allows one to show one's vulnerabilities. This opens up the possibility of an awareness and appreciation of the vulnerabilities of people in dialogue with one another. In this state of openness, the empathic response may be imbued with a quality of wishing to care for the other in a way that affirms her/his identity as a member of a shared human community.

Furthermore, this desire to care for the other constitutes the fundamental moment, a pivotal point in the intersubjective context in which connection with the other at a deeper level occurs. Caring for the other, I argue, evolves from being witnesses to each other's pain - the "witnessing dance" that brings former adversaries into step with each other - into the spiral movement of a new intersubjective context that edges them towards the centre of 
possibility and then upward towards the apex of transformation. The new intersubjective context that emerges allows acknowledgment and recognition of shared humanity with the other.

The "caring-for" element in empathy is the result of a deeper level of imagination and understanding of the Other's experience. This deeper level of imagination takes "feeling into" the mental state of the other to another level and asks the question, "What should I do about it?" Thus, rather than empathy considered simply as "resonance" or "mirroring", the notion of "empathic repair" 5 might usefully be applied to capture the transformation and potential that are necessary to build healing communities in deeply divided societies such as those that, like South Africa, are emerging from violent conflict.

\section{Illustration through Three Stories}

As has become evident, my discussion in this essay is inspired by Nelson Mandela's vision of a South African society that is based on the values of human connection, a society that turns away from categories that tend to dehumanise others to those that inspire the recognition of the humanity of others. Mandela's quest is one that continues to challenge not just South African citizens to be change agents. The relevance of Mandela's lessons extends far beyond South Africa and his stance on engaging with others has been applied in service of a global public good. This essay then is an attempt to address the question: how can we create moral spaces that would allow the imagining of relationships that bestow a sense of worth on others in ways that were not possible when social relationships were defined by hate and destructive forms of engagement? How can we use stories that illustrate a vision of moral imagination to inspire a new generation of leaders to become change agents?

I address these questions by exploring examples from my own work and from unique historical moments that have been illuminating examples of the kind of moral imagination that fosters dialogue outcomes that transcend violent and hateful pasts. These examples are less from the great philosophers and religious or political theorists than from ordinary people who themselves have suffered irreparably. The lessons from the examples I discuss below show that far from what the experts have said about what is (im)possible in human relationships in the aftermath of violent histories, the potentialities of the human spirit always present opportunities for the provocation of the sense of what I call reparative humanism. ${ }^{6}$

My exploration begins with a story from Nelson Mandela's era of leadership in South Africa. There are many examples I could share of the transformative possibilities engendered by Nelson Mandela's leadership - moments in his private interpersonal encounters, as well as extraordinary moments in his public and political life that continue to compel our attention. 
For South Africans, and indeed for citizens in the broader global context, Madiba's cause was for all humanity - humanity without borders. In South Africa, he engaged in his quest to dismantle unjust laws with a deep commitment to fairness that was inspired by the moral and political necessity for sustainable peace for people of all racial, religious and ethnic backgrounds to live together. With pragmatic compassion, he was guided by the clarity of his moral vision and a consciousness about the complexity of the human condition. The legacy of his wisdom continues to appeal to the better angels of our nature as we wrestle with the question of how to face the traumatic pasts of our histories without being caught up in cycles of repetition that will make us hostage to the violence and hatred inspired by this past. The following example stands out as one of the most poignant teachable moments in Nelson Mandela's leadership about how to reverse the tide of violence that almost gripped South Africa with its destructive chaos.

\section{The Murder of Chris Hani: Mandela's Interruption of Violence}

In April 1993, Chris Hani was gunned down in the driveway of his home in Boksburg. One of Hani's neighbours, a white woman, took the registration number of the assassin's car as he fled from the scene of the crime. Her call to the police led to the swift arrest of Hani's killer soon after the incident. But the arrest did little to quell the anger that was unleashed by Hani's murder. For many black South Africans, Chris Hani epitomised the ultimate fighter for the struggle for freedom against the oppressive rule of the white apartheid government. If Nelson Mandela in prison was the embodiment of the vision for freedom, Chris Hani, as the commander of the military wing of the African National Congress (ANC) Umkhonto we Sizwe ${ }^{7}$ kept that vision alive with its concrete expression.

When Hani was killed, the political negotiations for a multiparty democracy were in progress and the killing was seen as a ploy by white South Africans with right-wing political leanings to derail the negotiations process. Amidst fears that the country would erupt into waves of violence, Nelson Mandela appeared on prime time national television on the same day as Hani's assassination and made the following call for calm:

Tonight I am reaching out to every single South African, black and white, from the very depths of my being. A white man, full of prejudice and hate, came to our country and committed a deed so foul that our whole nation now teeters on the brink of disaster. A white woman, of Afrikaner origin, risked her life so that we may know, and bring to justice, this assassin [...] This is a watershed moment for all of us. Our decisions and actions will determine whether we use our pain, our grief, and our outrage to move forward to what is the only lasting solution for our country. ${ }^{8}$

In the end, Hani's assassination became a historical turning point, because the negotiations, which had stalled, moved forward with greater resolve, leading to a decision to hold South Africa's first all-race elections in April of the following year. 
Nelson Mandela was not yet president when he addressed South Africans to calm emotions that were threatening to explode. Yet, he was already setting the tone for the kind of leadership that the country needed at that moment and in the future. For Mandela, the critical moment of Hani's death was at once a moment of grief and a siren call reminding the nation of the vision for peaceful freedom and of the opportunity for dialogue that the negotiations had opened up. South Africans heeded the call, although sometimes with difficulty, and moved forward to embrace the horizon of hope that was Mandela's quest for the birth of a new country. The foundation for this quest was his vision that connection between former enemies was better than rekindling old hatreds. Throughout his journey to restore peace in South Africa, Mandela used moments of rupture as opportunities to break open the possibility for collective reflection, connection and restoration. He introduced a new language that transformed the narrative of violence in South Africa. It is no exaggeration to argue that in the years of Mandela's entry into politics and the public sphere, a strong sense of social solidarity and national pride that united South Africans across racial lines began to emerge.

Thus, the hope that Nelson Mandela inspired was grounded in the quest for South Africans to establish a richer sense of their identity as human beings, connected to others in the human community. He expanded the horizons of what is possible in human relationships by spearheading as part of the political negotiations a process of dialogue, fostering the capacity for connecting with others - including one's adversaries - in order to confront and heal a past characterised by moral corruption and widespread violations of human rights.

The need to build a world in which the Other matters is at the heart of Mandela's ethics of care. The hatred and mistrust induced by the divisions of the past need not lead to transgenerational racial animosity whereby the younger and subsequent generations become carriers of hate and perpetrators of new forms of violence that play out in endless cycles of repetition. The pattern can be broken, the violence transformed and the intergroup hatred transcended. Nelson Mandela's vision of care for the Other points us towards the "empathic repair" I referred to earlier in this essay, which is the language of mutuality that invites not only recognition of the other, but also the responsibility that calls each of us to participate in the rebuilding of our post-conflict societies and to share in the vision of human solidarity.

The significance of this need for connection in human relationships is captured by the notion of the "relational turn" in psychological research and psychoanalytic practice. Perhaps well-known among these scholars of the relational turn is Judith Jordan and her colleagues at the Wellesley Stone Centre who concluded from their studies that the need and proclivity for "connection" is central to human development. ${ }^{9}$ They are correct in arguing for the primacy of interconnectedness, a concept of development of self in 
interaction with others. In debunking the individualistic model of human development in which boundaries are created to establish a "separate self" in human development, Jordan has argued that from a relational perspective a "boundary" could be conceived of as a place of meeting and exchange with the surrounding milieu rather than as a place of protection from it. She and her colleagues provide a crucial counter-position for a problematical bias that has dominated psychology for too long. I would suggest that the re-conception of "boundary" as "a place of meeting and exchange", as they have argued, recognises certain ethical potentialities and perhaps draws attention to Martin Buber's notion of the "vital reciprocity" of human relationships. ${ }^{10}$ Nelson Mandela, too, in developing the vision of dialogue for South Africa's transition process, recognised the crucial significance of such reciprocity - that black South Africans in all their diversity of blackness (Coloured, Indian, African) and white South Africans had to face the past together in order to forge a shared future ahead. To invoke Mandela once again:

It was during those long and lonely years that my hunger for the freedom of my own people became a hunger for the freedom of all people, White and Black. The oppressed and the oppressor alike are robbed of their humanity. I knew as well as I knew anything that the oppressor must be liberated just as surely as the oppressed. ${ }^{11}$

\section{Simon Wiesenthal's Encounter with a Dying Nazi SS Soldier}

My second example is Simon Wiesenthal's story chronicled in his book The Sunflower: On the Possibilities and Limits of Forgiveness. The story was about his encounter with a dying Nazi soldier and of his visit to the soldier's mother after his (Wiesenthal's) liberation from a Nazi concentration camp. ${ }^{12}$ Wiesenthal was a survivor of the Nazi death camps who dedicated his life to hunting down Nazi perpetrators and documenting the crimes they committed. His book The Sunflower recounts the story of his encounter when he was a camp inmate with a dying SS soldier who asked for his forgiveness. In the book, Wiesenthal also describes his search for the home of the SS soldier and meeting his mother. Wiesenthal's book has paved the way for us to explore the question of what it means to be human in the aftermath of Nazi-era crimes in a way that has not been possible before. He has passed on to our generation, the post-Holocaust generation, the responsibility not simply to ponder the question of whether he was right or wrong not to forgive Karl the SS man, but rather to reflect on the question of what it means to be human in the wake of absolute evil. His book is unique in that his account reveals the potential for human connection in even the most unspeakably tragic circumstances. These extraordinarily human moments are captured in Wiesenthal's narration of a conversation he had with Karl's mother. At one point in his account of meeting the mother of the Nazi soldier, Wiesenthal tells readers that he could not shatter "this broken woman's image of her son as a 'good boy." "I took my leave," Wiesenthal writes, "without diminishing in any way the poor woman's last surviving consolation - faith in the goodness of her son." ${ }^{13}$ 
In the aftermath of the words-defying destruction and catastrophe in which Wiesenthal's loved ones were murdered, he demonstrated a sense of caring for the feelings of the "Other" despite the deep chasm that separated their worlds. This, to me, seems to convey the empathy that the mother's grief evoked in Wiesenthal. These moments in Wiesenthal's encounter with Karl the mass killer allow us to explore new avenues of inquiry that bear relevance to the moral question that Wiesenthal articulates for us in The Sunflower. The profound example of Wiesenthal's response to Karl's mother compels us to consider the question of what dynamics might drive victims towards empathy and lead them to enter into a constructive encounter with an Other who is responsible for their pain and loss even when their internal moral compass points towards its inappropriateness and the Other seems morally undeserving.

Wiesenthal walked away from Karl's deathbed without responding to the dying man's plea. Yet, he continued to wrestle with his decision to keep his silence and to walk away long after the SS soldier's death. The fact that his response - or lack thereof - led to a relentless reflection on the question of whether he did the right thing decades after his encounter with the young SS man suggests that the dying Karl's words affected him. Wiesenthal informs readers that the dying Nazi soldier "challenged my heart and my mind". ${ }^{14}$ This is what struck me the most about Wiesenthal's story when I first read it. He did not respond with the kind of revulsion that might be expected after meeting a person who has committed "radical evil" in Hannah Arendt's turn of phrase and dismiss the encounter with Karl as one that is unworthy of any further reflection. Rather, Wiesenthal continued to engage with it and to challenge us to put ourselves in his shoes and for each of us to ask the profound moral question: What would I have done?

A question often raised by scholars and religious leaders, who have been invited to participate in the seminars organised around Wiesenthal's dilemma, concerns whether Karl the SS man cared for Wiesenthal as an individual who had lost loved ones. The discussion of this issue has led some to conclude that Karl's quest was a selfish one, because he seemed to see Wiesenthal as "anonymous other" - the Jew that he had asked the nurse to find.

At the same time, however, one could argue that Karl recognised that Jewish people suffered the Nazi machinery of destruction collectively and that the crime he committed was a crime directed at Jews as a people. Therefore, it may be significant that Karl asked the nurse to call "a Jew". It seems to me that if he wanted only forgiveness he could have asked God to forgive him. Seeking connection with a living human victim, however, seems to suggest a desire for something else that went beyond forgiveness. I suggest that this something else was a hopeless hope to "repair" the irreparable legacy of brokenness he was about to leave behind. Like remorse, his was an act of accountability, facing his guilt and recognising that his actions caused a rupture in the human community beyond repair. This does not mean 
an absence of "self-serving" intentions - I see remorse as both self- and other-serving goals. It is positioning the perpetrator's reflection on his role in the past in relation to the victim's pain, seeking not to deny or erase that role, but rather to confront it to see the evidence of his deeds in the victim's human face and to be affected by it.

Yet, more than remorse, Karl the SS officer wanted confirmation of his human "being-ness". In other words, he needed a witness to guide him towards a state of being present among human beings. His last wish, I argue, was granted. More than seven decades after Karl asked Wiesenthal to forgive him, he continued to live in Wiesenthal's memory not as one of the evil SS officers who died in German army hospitals, but as Karl who challenged a Jew's heart and mind with his words of repentance for many decades to come. His story, chronicled by Wiesenthal as its only witness, is a poignant one - the message equally poignant - as it continues to pose the difficult questions about the limits of our imagination when it comes to forging relations with former enemies in the aftermath of violent histories, and how we might reclaim our sense of being human in the aftermath of unspeakable crimes against humanity.

How could we deepen our understanding of the message of The Sunflower? While victim and perpetrator are separated by their historical pasts, their past at the same time also connects them, opening up a potential space for the emergence of unexpected human moments. The next example illustrates this point.

\section{Forgiving Her Mother's Killer}

The final example is from an encounter between a young woman and her mother's killer during which she reaches out to him with forgiveness. Marcia Khoza was only five when her mother Portia Shabangu was killed in 1989 in Swaziland by Eugene de Kock and his men when De Kock was head of the apartheid government's notorious "covert operations" security police unit. De Kock, who came to be known as the apartheid government's "Chief Assassin,"15 appeared before the Truth and Reconciliation Commission (TRC) to testify about his crimes. He was granted amnesty for some of the crimes, but was serving two life terms in prison for crimes for which he did not receive amnesty, when Khoza visited him. At the end of the visit, Khoza left De Kock a book on forgiveness in which she had written the words: "I have been hurt and had a rough childhood without my mother, since 12 February 1989 ... I freely and fully forgive you, and I am ready to help others to heal."

What does it mean to face the man who killed her mother and to ask him questions about the killing? What did forgiving De Kock do for her - and for De Kock? What does it mean to forgive a man who in the collective consciousness of South Africans is the embodiment of the evil of the apartheid system? Khoza shared her responses to these questions at a public conversation event I had co-organised at the University of the Free State. ${ }^{16}$ 
"I had this deep void of emptiness," Khoza said. "I carried so much anger to protect myself from falling into the abyss." Empowered by knowing the story of her mother's killing and finally finding "the missing puzzle in the jigsaw of my life", as she described the experience, Khoza was able to mourn and to begin a new journey with her trauma. In recounting the story of her meeting with De Kock, she spoke about how the experience of hearing about her mother's last moments and other details about her killing brought her close to her mother as if she were present at the site of the crime. Yet, at the same time, meeting De Kock made it possible for her to transcend - and not necessarily to forget - the pain that she always felt whenever she thought about her mother. She could empathise with him and his longing for his sons whom he told her he had not seen for more than twenty years.

I asked her what was most memorable about the meeting with De Kock. She described a moment towards the end of the visit when she became conscious of her knees touching De Kock's under the narrow table across which they sat from each other in the prison. She was drawing closer and closer to him with each response he gave to her many questions, listening to the words, yet also listening to his "inner voice". At one point, she said, "I realised that our noses were almost touching, and that we were breathing the same air."

"Breathing the same air" is an ordinary statement, yet the extraordinary meaning it conveys, transcends Marcia Khoza's story and enters the realm of human affairs. The statement brings into focus the emergent possibilities that are at the heart of these dialogic processes of restorative justice. In societies emerging from violent conflict like South Africa where victims, perpetrators, bystanders and beneficiaries of oppressive regimes live in the same country and sometimes as neighbours, creating the space for such dialogue is an imperative.

As a metaphor, the notion of "breathing the same air" challenges the very concept of forgiveness. In considering encounters between survivors and perpetrators of gross human rights violations, what is perhaps necessary is shifting the lens from a focus on forgiveness and reconciliation (concepts that imply a goal) to "experience" (complicated, enigmatic, muddy, elusive and unpredictable) because I think that much of what happens in these encounters remains implicit and the word "forgiveness" falls short of adequately capturing this complexity at the heart of human connection.

\section{Conclusion: Empathic Repair and the Spirit of Ubuntu}

In this essay, I have tried to show how the three stories outlined above reveal to us a vision of moral imagination that may indeed inspire a new generation of leaders to become change agents by cultivating compassion for the other, even for one's enemy.

In this regard, I would like to argue that at the centre of this empathic human connection illustrated by these examples is "love" of humanity and that the concept and spirit of Ubuntu 
encapsulates this expression of love. This is a deep sense of caring for the other that is understood to be deeply embedded in most traditional African societies. It is worth noting that the post-amble of the South African Interim Constitution of 1993 which outlined the guidelines for the establishment of the TRC included a reference to "the need for Ubuntu". This clearly conveyed a particular orientation for the work of the TRC, one that was specific to the South African social and cultural context. The concept of Ubuntu is an ethic based on the understanding that one's subjectivity is inextricably intertwined with that of others in one's community. From the perspective of Ubuntu, all people are valued as part of the human community and worthy of being so recognised. This entails not blind acceptance of others no matter what they do, but rather an orientation of openness to others and a reciprocal caring that fosters a sense of solidarity. Ubuntu is often associated with the concept of self, "I am because we are", which stands in contrast to the Cartesian "I think, therefore I am." While recognising the role of the individual, Ubuntu values a sense of solidarity with others - the individual always in relation - rather than individual autonomy.

It seems to me, however, that the meaning of Ubuntu is best captured in the isiXhosa expression Umntu ngumntu ngabanye abantu. Literally translated, this means, "A person is a person through being witnessed by, and engaging in reciprocal witnessing of other persons," or "A person becomes a human being through the multiplicity of relationships with others." The meaning conveyed by the expression is twofold. First, subjectivity depends on being witnessed; the richness of subjectivity flows from interconnectedness with the wider community and from the reciprocal caring and complementarity of human relationships. Second, the phrase conveys the kind of reciprocity that calls on people to be ethical subjects. Mutual recognition is fundamental to being a fellow human being, a relational subject in the context of community. A person with $U$ buntu "is open and available to others, is affirming to others ... My humanity caught up, is inextricably bound up, in yours." ${ }^{17}$

Only a few years after the passing of Nelson Mandela in December 2013, the need to return to his vision in South Africa remains clear. The killings of striking mineworkers by the South African police, the ongoing violence against girls and women, violent demonstrations against poor service delivery in black people's residential areas across South Africa, the ever-widening gap between rich and poor and the massive corruption at the highest level of government are all examples of the kind of "watershed moment" that Nelson Mandela referred to when he addressed South Africans after Chris Hani's murder. South Africa is a troubled country. But South Africa is not alone in experiencing a troubled state of the nation. Recently, the United States has been confronted with statements made by its president which threaten to shatter America's foundation of democracy and the very notion of global human rights. As some of us respond with outrage to the terrible things that happen in our countries, we may wish to remember Mandela's call "to use our pain, our grief, and our outrage" to reconnect with our common humanity and instead of becoming 
stuck in despair, "to move forward" and find meaning and inspiration in the richness of the lessons he left behind. His is a call to citizens of the world to march in step on the path that leads to hope - hope that our shared vision of compassion and empathy for the suffering of the other will lead us on the path of moral imagination - to care enough to do something about the structures that continue to fuel hate and violence in the various spaces we inhabit.

\section{Bibliography}

Agassi, Judith. Martin Buber on Psychology and Psychotherapy: Essays, Letters, and Dialogue. Syracuse, NY: Syracuse University Press, 1999.

Arendt, Hannah. The Human Condition. 2nd edition. Chicago and London: University of Chicago Press, 1998. https://doi.org/10.7208/chicago/9780226924571.001.0001

Black, David M. "Sympathy Reconfigured: Some Reflections on Sympathy, Empathy and the Discovery of Values." The International Journal of Psychoanalysis 85/3(2004): 579-596. https://doi.org/10.1516/ 2A57-EY8X-XEUU-AFPN

Gobodo-Madikizela, Pumla. "Empathic Repair after Mass Trauma: When Vengeance Is Arrested." European Journal of Social Theory 11 (2008): 331-350. https://doi.org/10.1177/1368431008092566

Gobodo-Madikizela, Pumla. "Reconciliation: A Call to Reparative Humanism." Pages 133-139 in In the Balance: South Africans Debate Reconciliation. Edited by Fanie du Toit and E. Doxtade. Cape Town: Jacana, 2010.

Gobodo-Madikizela, Pumla. A Human Being Died that Night: A South African Story of Forgiveness. Boston, MA: Houghton Mifflin, 2003.

Jordan, Judith. "A Relational-cultural Model: Healing through Mutual Empathy." Bulletin of the Menninger Clinic 65 (2001): 92-103. https://doi.org/10.1521/bumc.65.1.92.18707

La Grange, Zelda. Good Morning, Mr Mandela. New York: Plume, 2015.

Mandela, Nelson. A Long Walk to Freedom: The Autobiography of Nelson Mandela. Boston, MA: Little, Brown \& Company, 1994.

Merleau-Ponty, Maurice. The Visible and the Invisible, transl. Alphonso Lingis. Evanston, IL: Northwestern University Press, 1968.

Tutu, Desmond. No Future without Forgiveness. London: Image Books/Random House, 1999.

Wiesenthal, Simone. The Sunflower: On the Possibilities and Limits of Forgiveness. New York: Schocken, 2008.

\section{Endnotes}

1 Zelda La Grange, Good Morning, Mr. Mandela (New York: Plume, 2015).

2 Nelson Mandela, A Long Walk to Freedom: The Autobiography of Nelson Mandela (Boston, MA: Little, Brown \& Company, 1994), 542.

3 Maurice Merleau-Ponty, The Visible and the Invisible (transl. Alphonso Lingis; Evanston, IL: Northwestern University Press, 1968), 49.

4 David Black, "Sympathy Reconfigured: Some Reflections on Sympathy, Empathy and the Discovery of Values," The International Journal of Psychoanalysis 8/3 (2004): 579-596.

5 Pumla Gobodo-Madikizela, "Empathic Repair after Mass Trauma: When Vengeance is Arrested," European Journal of Social Theory 11 (2008): 331-350.

6 Pumla Gobodo-Madikizela, "Reconciliation: A Call to Reparative Humanism," in In the Balance: South Africans Debate Reconciliation, ed. Fanie du Toit \& E. Doxtade (Cape Town: Jacana, 2010), 133-139.

7 Umkhonto we Sizwe, which means "The Spear of the Nation", was the armed wing of the African National Congress (ANC). It was established by Nelson Mandela and his comrades in the aftermath of the March 1960 Sharpeville Massacre in which protesters against the apartheid government's "pass laws" were killed by the police.

8 Nelson Mandela addressing South Africans on national television after the assassination of Chris Hani, 10 April 1993. 
9 Judith Jordan, "A Relational-cultural Model: Healing through Mutual Empathy," Bulletin of the Menninger Clinic 65 (2001): 92-103.

10 Judith Agassi, Martin Buber on Psychology and Psychotherapy: Essays, Letters, and Dialogue (Syracuse, NY: Syracuse University Press, 1999), 85.

11 Nelson Mandela, Long Walk to Freedom: The Autobiography of Nelson Mandela (Boston, MA: Little, Brown \& Company, 1994), 624.

12 Simon Wiesenthal, The Sunflower: On the Possibilities and Limits of Forgiveness (New York: Schocken, 2008).

$13 \mathrm{lbid}, 94$.

$14 \mathrm{lbid}, 95$.

15 See Pumla Gobodo-Madikizela, A Human Being Died that Night: A South African Story of Forgiveness (Boston, MA: Houghton Mifflin, 2003).

16 Marcia Khoza spoke about her prison encounter with Eugene de Kock at a public dialogue event I had organised at the University of the Free State, titled "Who is Eugene de Kock Today?" Public Dialogue with Marcia Khoza and Piet Croucamp in the lecture series, titled "Dialogue between Science and Society", in collaboration with the Institute for Reconciliation and Social Justice, University of the Free State, 2 December 2013.

17 Desmond Tutu, No Future without Forgiveness (London: Image Books/Random House, 1999), 31. 


\section{THE CASE OF THE TRAFFICKED PRINCESSES (JER 40-44) \\ Trauma Hermeneutics as Pedagogical Tool for Teaching on Gender-Based Violence}

L. Juliana Claassens

Faculty of Theology Stellenbosch University

\section{Introduction}

The 2016 \#EndRapeCulture campaign in Stellenbosch was marked by two striking occasions. One evening in April 2016, the fire alarms went off at 2.00 a.m. across campus in order to signal the message that the student community would no longer be silent about their fellow students being raped, as in the case of the student who was raped outside the Harmony residence that triggered this protest. ${ }^{1}$

And, at the Woordfees in March 2016, a group of young women drew even further attention to this matter by, in the spirit of the Ukraine group Femen, appearing topless at one of the events, clearly communicating that their bodies, even though naked, are not for trespassing. ${ }^{2}$

These two examples of public protest did well to spark public debate of the ongoing reality of sexual violence. However, as an educator who regularly teaches on topics pertaining to gender-based violence, also in biblical studies courses such as the Hebrew Bible Prophets, I am of the opinion that such public protest should be supplemented with sustained conversations in classrooms, churches and other places where people are gathered to learn about the rampant reality of sexual violence that truly is a global phenomenon. Over the years, I have found that stories that narrate the reality of sexual violence are a powerful pedagogical tool for raising awareness regarding the problem of rape that is indeed systemic in nature. Moreover, as evident in the public protest regarding \#EndRapeCulture, some students are well aware of the reality of sexual violence that has sparked these protests; however, the classroom conversations generated by these rape narratives provide them 
with the opportunity to collectively grapple with the extent of the problem, as well as consider creative avenues for resistance and transformative change to occur. For the purpose of this essay, I want to do two things. In the first instance, I will give some attention to the question of why stories, both ancient and modern, are so helpful when teaching on sexual violence. In this regard, recent developments on trauma hermeneutics offer an important heuristic device in reading the biblical text in a way that does justice to contemporary concerns of pain and suffering. In the second instance, this essay will consider the potential of a biblical story that is not a typical "rape text", the story of what Wilda Gafney creatively has called the "trafficked princesses" 3 as narrated in Jeremiah 40-44 for teaching the subject of sexual violence.

Read through the lens of feminist critical and postcolonial biblical interpretation, this quite minor story of the daughters of King Zedekiah who had been taken hostage by the renegade leader Ishmael and then passed along like pawns from one group of leaders to the next draws our attention to the myriad of ways in which women in particular are vulnerable, especially in the context of war and forced migration. This essay proposes that stories like the one of the "trafficked princesses" in Jeremiah 40-44 hold great promise in helping raise awareness about the reality of sexual violence in many communities around the world, and especially in the context of migration and the recent refugee crisis. I propose that stories - both ancient and modern - that reflect the trauma of sexual violence are vital in the broader task of teaching students about the reality of sexual violence and particularly the systemic nature thereof, as well as the creative possibilities of female agency within dignity-denying circumstances.

\section{Art/Trauma/Representation}

Trauma hermeneutics has helped us understand the integral link between trauma and art as means of survival for individuals and communities who find themselves in situations of extreme duress. With regard to the biblical prophets, Louis Stulman writes that a book such as Jeremiah can be considered "meaning-making art" that serves the purpose of helping traumatised individuals and groups to make sense of their suffering. ${ }^{4}$ He describes how prophetic literature turned trauma survivors into artists of sorts, active meaning-makers who were in the process of mapping out meaning in contexts of radical suffering. ${ }^{5}$

By means of poetry, throbbing with raw emotion and pain, as well as the few rather convoluted narratives reflecting multiple layers of trauma and suffering, the authors of the prophetic books sought to capture something of the violence the community had lived through. ${ }^{6}$ As Stulman writes, "This ancient artistic expression refuses to deny the atrocities of war; it protests and dissents." This is "art for the sake of communal survival; art that defies, not denies, the wreckage of its times". 
But beyond its important function to help trauma victims face what had happened to them, these examples of "textual art" represent and honour the victims of the terrifying violence that the community had lived through in a unique fashion. ${ }^{9}$ Indeed, as Stulman has well said, "Art steps forward on behalf of victims of unspeakable violence. Art steps forward to imagine a world in and through and beyond the traumatic violence." 10

This act of representing trauma in the form of art furthermore serves as a means by which we as readers can bridge the vast divide in space and time that exists between our own context and that of the biblical writers so many centuries ago. Daniel Smith-Christopher poignantly writes about this imaginary link between then and now that is fostered by means of a shared understanding of the reality and effects of trauma thus: "Or we can pause - and deal with our human temptation to reach across the centuries to the writer of a work like this and put our hand on their shoulder and simply ask, "Are you OK?"11 Smith-Christopher notes that the reason for this empathetic gesture is the suspicion "that many of the writers of the Bible are not 'ok', and part of our task is to think together about what this means." ${ }^{12}$ Indeed, by means of our encounter with textual art that seeks to represent the traumatic events of the past, we become, as Smith-Christopher has argued, 'secondary witnesses' to the suffering of others in both the ancient and modern world" ${ }^{13}$

A good example of this blurring of time and space, which is described by Else Holt as an act of "making past time present", is to be found in the story that tells of the reflections of a descendant of a Holocaust survivor as he visited Auschwitz with which she starts her article on "Trauma, Cultural Memory and Gender". This young man reminisces as follow:

Today we go to Auschwitz. By the time we enter, I have changed from being a 'surviving grandson' to being equal, arriving at the gates from the past in the past. Only now can I finally die with Josef, Dora, and my father Hans. Later as I walk back through the camp entrance at Birkenau, I am reborn, in my present life. As witness, not as survivor. ${ }^{15}$

Actually, this ability of art to forge a connection with viewers from other times and places in terms of the representation of trauma that evokes a measure of emphatic understanding is illuminated in a fascinating article on Art/Trauma/Representation by Pollock who considers "the performative process in artwork, that takes, and indexes, its own time and creates a new space of encounter". ${ }^{16}$ This "virtual encounter" facilitated by the artistic expression of an individual or group from a long time ago and in a different corner of the world serves, according to Pollock, as a "transsubjective borderlinking with its own known and unknown others, its own and others' histories, its own sensitivities to the world". ${ }^{17}$ By means of the "aesthetic encounter", the reader/viewer is transported "into other spaces and times in an equally affecting way which can only resonate in [the reader] because of the specificities" he/she brings to the artwork. Moreover, Pollock notes that a particular artistic expression may resonate on some unconscious level with the reader/viewer that might not have been evident before. ${ }^{18}$ 
This "transsubjective borderlinking" is well illustrated in the story with which Holt ends her article. She writes how another Jewish youth, when he was looking at a display of shoes from some of the Holocaust victims in Majdanek, looked down at his own shoes and, upon seeing that the shoes on display did not look that much different from his own, concludes, "It seems as though every shoe here is my shoe." ${ }^{19}$

With regard to this ability of stories as expressions of textual art to both represent trauma and forge a connection across time and space in an aesthetic encounter that creates new levels of awareness and insight, in the following section, we will look at one particular story that narrativises the plight of a group of migrant women who are passed along from one renegade leader to another and the potential it holds to speak about the ongoing reality of sexual violation.

\section{Trafficked Princesses}

The story of the Trafficked Princesses - as Wilda Gafney so intriguingly calls these royal princesses in Jeremiah 40-44 - is embedded in a much larger story of violence and murder. In the first 39 chapters of the Book of Jeremiah, the reality and the effects of the Babylonian invasion and exile are captured in some of the most graphic and brutally honest poetic images as the traumatised prophet representing the traumatised people seeks to come to terms with the devastating calamity. In Jeremiah 40-43, an episodic narrative is told that outlines some greatly traumatic events that transpire in the aftermath of the Babylonian attacks. One reads in Jeremiah 40 of the shocking events of the assassination of the newly appointed Governor Gedaliah, who in Mizpah had sheltered some members of the royal household, including a number of Judean princesses. The assassination of the governor and his officials by the renegade leader Ishmael is followed by the so-called "Mizpah massacre" that saw the ruthless murder of eighty survivors from the towns of Shechem, Shiloh and Samaria who had arrived wounded and humiliated in Mizpah after the Babylonian invasion.

These eighty men who were so brutally slain had travelled to Mizpah in order to bring grain offerings and incense to the temple of the Lord; hence, turning to God amidst their great anguish. Outside of the city, a seemingly concerned Ishmael came forth to greet them (cf. the reference to Ishmael weeping in Jer 41:6). After inviting the weary travellers into the city to "meet" Gedaliah (whom the reader knows has been murdered!), Ishmael proceeds to slaughter them, throwing their bodies into a deep cistern.

It is at this point of the narrative, in a context of terrifying violence and mass killing, that we encounter the story of the Judean princesses. After the massacre at Mizpah, Ishmael continues his rule of terror by taking captive the survivors, including the king's daughters, and sending them into exile to Ammon (Jer 41:10). 
The plight of these royal princesses does not end here though. They are passed along to yet another military leader Johanan who, upon hearing about the terrible things Ishmael had done (Jer 41:11), together with his men goes to fight against Ishmael. This military offensive proves successful when Johanan manages to free all the people that Ishmael had taken into captivity.

On the one hand, one could view Johanan as the great liberator who has led all the people the soldiers, women, children and eunuchs who had been taken hostage by Ishmael - out of captivity. However, when viewed from the perspective of the trafficked princesses, we see that once again these women have no voice and no choice as they are being passed along from one male leader to the next. They inadvertently end up in Egypt - the place where the "liberator" Johanan leads all the men, women and children, including the Royal Princesses who survived the massacre at Mizpah (Jer 43:4-7). This reference to Egypt is rather ironic given that in the book of Exodus, Egypt was precisely the place of captivity from where the liberator Moses had led the people. ${ }^{20}$ In contrast to Jeremiah 40:4-6, when Jeremiah still had some measure of agency and was offered the choice as to where he would like to go, in Jeremiah 43:6, the prophet, together with Baruch, is taken along to Egypt clearly against his will (cf. Jeremiah's fierce critique against the group going to Egypt in Jer 42:10-22). How much more is this lack of agency true in the case of the trafficked princesses who also find themselves as migrants in a foreign land?

Now this very minor story of a group of women who, like the objects that their society deemed them to be, are passed along from one leader to the next could quite easily be missed. However, the hidden story of the plight of the trafficked princesses actually offers a great example of a text that, if read through a distinctive lens focusing on the trauma represented by the text, demonstrates the ability of stories to forge a common connection rooted in a shared sense of suffering. This story narrates not only the trauma of the ongoing reality of the damaging effects of empire and the power struggles that followed in its wake, but also the conceivable reality of sexual violation. In this regard, Gafney reads this story through the lens of the \#BlackLivesMatter and \#SayHerName campaigns connecting the pain many black women in the United States continue to experience by being overlooked or only regarded in terms of their sexual value with the plight of these unnamed/unnoticed princesses who have been passed along from one leader to another. She seeks to give back to each of these women some sense of dignity by "saying her name".

Also Christl Maier reads this story in the context of migration specifically in terms of the so-called refugee crisis in Germany. She argues that in light of the watershed events of 3-4 September 2015 when Germany and Austria opened their borders, the great number of despondent refugees who entered Germany - the country of their hopes and dreams - in search of a place of safety and security for themselves and their families has much in 
common with the group of refugees who after the Mizpah massacre sought a safe haven in Egypt. She writes: "Both stories narrate situations after or during war where some people flee to a foreign land out of fear for their life and because they see no future for themselves in their country of origin." ${ }^{22}$

Both Maier's focus on the plight of the refugees and Gafney's emphasis on the "trafficked princesses" serve to show how narratives that come from a very different time and place are able to speak to individuals and communities - in Pollock's words, an act of "transsubjective borderlinking". I propose that such an interpretative act may help contemporary readers to ponder the reality and the effects of sexual violence. In the following section, four themes will be highlighted that might be conducive to a conversation on sexual violence today.

\section{Transsubjective Borderlinking}

In the first instance, we see how the hidden story of the trafficked princesses as told in Jeremiah 40-44 encourages us to "wit(h)ness" the trauma of those women to continue to experience violation and objectification. This story thus draws our attention to the vulnerable bodies of women who are objectified, sexualised and commoditised then, but sadly still, to this day, in all corners of the world. The fact that one has to look harder and deeper to notice this particular story of sexual violation hidden away in Jeremiah 40-44 is a good exercise to also be intentional in looking for those stories of women's violation that as a rule are overlooked and disregarded. To notice the hidden stories of women's violation that often get lost in the wars of men in the biblical texts encourages us to be more conscious in finding stories of the violation experienced by female migrants that are not always brought to light.

A good example in this regard are the stories that document the sexual violation of female migrants who similarly disappear among the deluge of stories outlining the plight of the so-called refugee crisis in Europe that in particular has hit Syrian refugees hard. In terms of what has been called the "feminisation of migration", Laura Tennenhouse shows the myriad of ways in which women are especially vulnerable as migrants. ${ }^{23}$ In this regard, Tennenhouse cites the work of Katrin Bennhold who highlights the constant threat of abuse from male family members, sexual assault and rape experienced by female refugees. One refugee named Samar talks of the way in which women's voices are drowned out, how "everyone knows that there are two ways of paying smugglers ... with money or with your body". ${ }^{24}$ Samar herself, after their family's funds ran out, was sold by her husband and repeatedly raped in order to pay for her family's safe passage to Europe. ${ }^{25}$ This reality of female migrants' bodies serving as commodities often negotiated by male family members in order to ensure the survival of the family is eerily reminiscent of the plight of the trafficked princesses and the objectification they experienced during their journey to Egypt. 
Second, the story of the trafficked princesses as told in Jeremiah 40-44 draws our attention to the systemic nature of sexual violence. The story that narrates the denial of the women's agency and voice and conceivably also of sexual violation by their captors is embedded in a larger multi-levelled story of systemic violence. This group that gathers at Mizpah has survived a most brutal display of imperial violence during the Babylonian invasion. At Mizpah, these victims/survivors are not safe, but are rather subjected to a further display of violence - this time at the hand of their own people. In some ways, the events narrated in Jeremiah 40-44, including the assassination of Gedaliah, the brutal murder of the survivors from the Babylonian invasion and the forced removal of the people of Mizpah to the Ammonites is a double blow, because the violation does not come from external imperial forces. It comes from fellow Judeans who are vying for power in the aftermath of the disaster.

This situation is all the more troubling, because it seemed as if things were just starting to get better again, especially with the survivors taking the first steps to reconnect with life and to return home by engaging in such ordinary acts, as looking for food and eating together, that serve as an important part of the arduous process of recovering from trauma (Jer 40:10-12). Just when people thought the worst to be over, just when they had resumed religious activities such as going to the temple to worship God and conceivably give thanks to God for surviving the war (Jer 41:5), violence erupts once more with brutal force.

Things today are no different. Women continue to have to fend off threats not only from outside, but also from within. Tennenhouse shows, for instance, how for many migrant women, it is their own fathers and husbands who themselves had been the victims of violence who are responsible for the violation. ${ }^{26}$ And one does not have to look too far to see how this multi-levelled systemic nature of sexual violence extends throughout our own society from the home to the workplace, in townships and in affluent neighbourhoods irrespective of colour or creed.

Third, the plight of the "trafficked princesses" and, in particular, their lack of agency and lack of voice, mirrors the utter inability of trauma victims in general to speak about what they have experienced. Kathleen O'Connor writes that "victims can rarely speak adequately about traumatic violence because memories of violence keep overwhelming them. Language fractures and breaks down so people are unable to express their experiences, leaving them bereft and isolated". ${ }^{27}$ In this regard, a story like the one of the trafficked princesses in Jeremiah 40-44 may conceivably help victims of trauma both then and now to speak about the reality and the effects of violence. It is exactly through the medium of art that such representations may gently help to ease victims into speaking about their violation. O'Connor says this beautifully:

This early process of symbol-making is a delicate one because literal retellings of traumatic events can call forth recurring memories of the original violence and re-traumatize victims, who then remain 
stuck in the recurring memories of the violence. To protect victims from being overwhelmed again by memories and to expose them gently, slowly, and partially to the violence they have endured, language has to be flexible, allusive, and evocative. ${ }^{28}$

Ironically, it is thus exactly the absence of the trafficked princesses' voices coupled with a profound lack of agency quite similar to the plight of the prophet Jeremiah and his scribe Baruch that serves a symbolic function that represents the suffering of the people as a whole. As Elizabeth Boase notes with regard to the portrayal of Daughter Jerusalem in the book of Lamentations, it is "the body of the woman" that is "represent[ing] the body of those who suffer". ${ }^{29}$ In the book of Lamentations, but also in this story of the trafficked princesses as told in the book of Jeremiah, one could thus say that embodied language is used in order to foster a sense of communal identity. Boase proposes that,

Naming suffering through the use of culturally familiar, embodied metaphors helps to bridge isolation ... We experience the world in our bodies. Evoking bodies connects us to other bodies. The language and metaphors help re-member the body, to bring back together the communal body by the naming of shared experience. ${ }^{30}$

In this way, one finds that stories that narrate the sexual violation of a group of women serve as a means for the community as a whole to deal with their pain. ${ }^{31}$ This said, one should immediately point out the difficulties with this rhetorical strategy as it once again offers evidence of how women's broken, violated bodies are used for a purpose beyond their own selves. ${ }^{32}$ And yet, from across the divide of time and space, the trauma of another implores us in an ethical moment to do something to prevent others from suffering a similar fate as well.

Finally, even amidst this story that narrates the objectification of a group of women who are utterly silenced and almost erased, we do find some signs of resistance that speak of agency in spite of oppression. Both Gafney and Maier read the reference in Jeremiah 44:18-19 of the women worshiping the Queen of Heaven as a sign of religious independence. Gafney points out that this group of women, presumably the trafficked princesses of Jeremiah 41-43 included, could be understood as an important sign of women reclaiming their agency by worshipping a deity that is more reflective of their experience. ${ }^{33}$

Actually, the fact that these migrants worshipped at all is a sign of recovery. O'Connor writes that victims of trauma quite often "lose faith and trust in institutions, traditions, and in God. After disaster, beliefs that once supported life break down in a vacuum devoid of meaning" ${ }^{34}$ Hence, when the women in particular are singled out for re-engaging in religious activities, it is a sure sign that they are well enough to once more participate in sense-making activities in their new home. In this regard, Maier writes that,

In their speech, the women positively link themselves, to the customs of their ancestors and the time before the fall of Jerusalem. They explain their current misfortune with the neglect of a female deity, the veneration of which involved the whole family as stated in Jer 7:18 ... Children gather 
wood, fathers kindle fire, women knead dough to make cakes for the Queen of Heaven. Thus they resort to a religious practice that they think is beneficial for their life. ${ }^{35}$

This account of worshipping the Queen of Heaven in Jeremiah 44 is a compelling example of the difference between the official and popular religion that quite often also has been linked to a gender differentiation in the biblical text (Jer 7:18). But without drawing moral judgements on the merits of their religious expressions, it is important to recognise the clear signs of female agency that serve as a unique expression of women's experience that often tends to be demonised. For instance, in this text as also earlier in Jeremiah, all the blame is placed on women who are scapegoated for all that went wrong (Jer 2-3). However, viewed from another perspective that is intentional about honouring the women's religious activities as a sign of their agency and equality, the prophet and the book of Jeremiah's overall goal to try and make sense of the senseless so as to bring order once more into a tumultuous world, the worship of the Queen of Heaven can be said to be an attempt by individuals to control their world, deeply believing that their failure to worship the Queen of Heaven is the cause for all of the suffering they had lived through (Jer 44:17-19).

\section{Conclusion}

The case of the trafficked princesses that is hidden away in the book of Jeremiah tells us something that many of us know all too well in our bodies and psyches. Women's ways in a man's world are never simple and straightforward, but rather quite complex and sometimes even painful, to say the least. Even despite the gains we have made - and there are many - we are left at times without voice and with a limited or diminished sense of agency. However, the fact that we can connect with stories that represent in art the painful struggles of women, both real and imagined, both recent and from a long time ago, is testimony to the fact that we are able to put our experiences into words so as to share our stories with trusted confidants who offer a safe space. From this place, this "homeplace" in bell hooks ${ }^{36}$ words, we become whole again and strong again in order to, with courage and conviction, continue to work for a world where violence is no more.

It is precisely this point of "transsubjective borderlinking" that offers a point of connection between our situation and the world reflected in the text that makes stories, both ancient and modern, such a helpful pedagogical tool when teaching on sexual violence. The biblical story of the suffering and violation the "trafficked princesses" in Jeremiah 40-44 experienced, in an indirect way may help students see the truth of their own situation, helping them to grow in insight regarding the reality of sexual violence in contexts near and far that quite often can be said to be systemic in nature. Moreover, as evident in the \#EndRapeCulture protests, more and more individuals and groups turn to public protest, saying a loud and clear "No" to all instances of gender-based violence. 


\section{Bibliography}

Alexander, Kayla. "Woordfees: 'Betoging Oor Verkragting - Nie Teen Sjef'." Die Burger. Cited 5 March 2016. Online: http://www.netwerk24.com/Nuus/Algemeen/woordfees-betoging-oor-verkragting-nie-teen-sjef20160305

Bennhold, Katrin. "On Perilous Migrant Trail, Women Often Become Prey to Sexual Abuse." The New York Times. Cited 26 March 2017. Online: https://www.nytimes.com/2016/01/03/world/europe/on-perilousmigrant-trail-women-often-become-prey-to-sexual-abuse.html? $r=0$

Boase, Elizabeth. "The Traumatized Body: Communal Trauma and Somatization in Lamentations." Pages 193-209 in Trauma and Traumatization in Individual and Collective Dimensions: Insights from Biblical Studies and Beyond. Edited by Eve-Marie Becker, Jan Dochhorn and Else Holt. Göttingen: Vandenhoeck \& Ruprecht, 2014. https://doi.org/10.13109/9783666536168.193

Claassens, L. Juliana. "Jeremiah" in The Paulist Bible Commentary. Edited by Aguilar Chiu, José E.; Clifford, Richard J.; Dempsey, Carol J.; Schuller, Eileen M.; Stegman, Thomas D. and Witherup, Ronald D. New York: Paulist, 2018.

Gafney, Wilda C. "Princess Propaganda: Forced Migration and Royal Women Hostages." Paper presented at the Annual Society of Biblical Literature Meeting, San Antonio, Texas, 20 November 2016.

Guest, Deryn. "Hiding Behind the Naked Women in Lamentations: A Recriminative Response." Biblical Interpretation 7/4 (1999): 413-448. https://doi.org/10.1163/156851599X00308

Holt, Else K. "Daughter Zion: Trauma, Cultural Memory and Gender in OT Poetics." Pages 162-176 in Trauma and Traumatization in Individual and Collective Dimensions: Insights from Biblical Studies and Beyond. Edited by Eve-Marie Becker, Jan Dochhorn, and Else Holt. Göttingen: Vandenhoeck \& Ruprecht, 2014. https://doi.org/10.13109/9783666536168.162

hooks, bell. Yearning: Race, Gender, and Cultural Politics. Boston, MA: South End Press, 1990.

Maier, Christl M. "Listening to the Trauma of Refugees in Jeremiah 44." Paper presented at the Annual Society of Biblical Literature Meeting, San Antonio, Texas, 20 November 2016.

O'Connor, Kathleen M. "How Trauma Studies Can Contribute to Old Testament Studies." Pages 210-222 in Trauma and Traumatization in Individual and Collective Dimensions: Insights from Biblical Studies and Beyond. Edited by Eve-Marie Becker, Jan Dochhorn, and Else Holt. Göttingen: Vandenhoeck \& Ruprecht, 2014. https://doi.org/10.13109/9783666536168.210

Pollock, Griselda. "Art/Trauma/Representation." Parallax 15/1 (2009): 40-54. https://doi.org/10.1080/13534 640802604372

Smith-Christopher, Daniel L. "Trauma and the Old Testament: Some Problems and Prospects." Pages 223-243 in Trauma and Traumatization in Individual and Collective Dimensions: Insights from Biblical Studies and Beyond. Edited by Eve-Marie Becker, Jan Dochhorn and Else Holt. Göttingen: Vandenhoeck \& Ruprecht, 2014. https://doi.org/10.13109/9783666536168.223

Steenkamp, Tanya. "Students and Academics Unite against Rape Culture." Die Matie 75/2. Cited 6 April 2016. Online: https://issuu.com/diematie/docs/die_matie 6_apr_2016

Stulman, Louis. "Reading the Bible through the Lens of Trauma and Art." Pages 177-192 in Trauma and Traumatization in Individual and Collective Dimensions: Insights from Biblical Studies and beyond. Edited by Eve-Marie Becker, Jan Dochhorn and Else Holt. Göttingen: Vandenhoeck \& Ruprecht, 2014. https://doi.org/10.13109/9783666536168.177

Tennenhouse, Laura. "Low Places Where Grace Abides: A Theology of Maternal Lament in the Context of the Syrian Refugee Crisis." Paper presented at the American Academy of Religion Annual Meeting, San Antonio, TX, November 2016.

\section{Endnotes}

1 Tanya Steenkamp, "Students and Academics Unite against Rape Culture," Die Matie 75/2. Cited 6 April 2016. Online: https://issuu.com/diematie/docs/die_matie___6_apr_2016

2 Kayla Alexander, "Woordfees: 'Betoging Oor Verkragting - Nie Teen Sjef'," Die Burger. Cited 5 March 2016. Online: http://www.netwerk24.com/Nuus/Algemeen/woordfees-betoging-oorverkragting-nie-teen-sjef-20160305

3 Wilda C. Gafney, "Princess Propaganda: Forced Migration and Royal Women Hostages." Paper presented at the Annual Society of Biblical Literature Meeting, San Antonio, Texas, 20 November 2016. 
4 Lovis Stulman, "Reading the Bible through the Lens of Trauma and Art," in Trauma and Traumatization in Individual and Collective Dimensions: Insights from Biblical Studies and Beyond, ed. Eve-Marie Becker, Jan Dochhorn and Else Holt (Göttingen: Vandenhoeck \& Ruprecht, 2014), 183. Daniel L. Smith-Christopher, "Trauma and the Old Testament: Some Problems and Prospects," in Trauma and Traumatization in Individual and Collective Dimensions: Insights from Biblical Studies and Beyond, ed. Eve Marie Becker, Jan Dochhorn and Else Holt (Göttingen: Vandenhoeck \& Ruprecht, 2014), 238.

5 Stulman, "Reading the Bible through the Lens of Trauma and Art," 183.

6 Stulman cites the example of 'gaman' - a Japanese term denoting art that emerges out of extreme suffering - which as Stulman notes bears the "seemingly unbearable with patience and dignity". Ibid, 182.

7 lbid, 177.

8 Ibid, 182.

9 Ibid.

$10 \mathrm{lbid}, 183$.

11 Smith-Christopher, "Trauma and the Old Testament," 229.

12 lbid, 229.

13 lbid, 241-242.

14 Else K. Holt writes that "the texts we encounter are themselves struggling to overcome" this distance "between their defining past and their contemporary present in exilic/post-exilic times". See Else K. Holt, "Daughter Zion: Trauma, Cultural Memory and Gender in OT Poetics," in Trauma and Traumatization in Individual and Collective Dimensions: Insights from Biblical Studies and Beyond, ed. Eve-Marie Becker, Jan Dochhorn and Else Holt (Göttingen: Vandenhoeck \& Ruprecht, 2014), 163.

15 Kugelmass, "Missions, 202, Quoted in Holt, "Daughter Zion," 162.

16 Griselda Pollock, "Art/Trauma/Representation," Parallax 15:1 (2009): 42. Cited 10 March 2017. Online: http://dx.doi.org/10.1080/13534640802604372

17 Pollock, "Art/Trauma/Representation," 48.

18 lbid

19 Holt, "Daughter Zion," 175.

20 The book of Jeremiah offers a variety of competing visions of how to survive imperial domination. One such very strong proposition is found in the pro-Golah position reflected in Jeremiah's stark judgement in Jer 42:16-22 against those who go to Egypt, saying that all kinds of tragedies, famine, sword, pestilence will befall them there. Even though this line of thinking presents as Christl M. Maier has argued a "master narrative that shapes the collective identity of post-exilic Judeans", it is rather ironic that Jeremiah himself ends up in Egypt among those refugees he condemns. See "Listening to the Trauma of Refugees in Jeremiah 44." Paper presented at the Annual Society of Biblical Literature Meeting in San Antonio, Texas, 20 November 2016, 7. This contradiction and tension reflected in this book serve the purpose of communicating the point that clearly in the aftermath of the Babylonian invasion, no good options exist, which make discerning exactly what is right exceedingly difficult. Cf. more on this L. Juliana Claassens, "Jeremiah," in The Paulist Bible Commentary, ed. José E. Aguilar Chiu et al. (New York: Paulist Press, 2018).

21 Gafney, "Princess Propaganda."

22 Maier, "Listening to the Trauma of Refugees in Jeremiah 44."

23 Laura Tennenhouse, "Low Places Where Grace Abides: A Theology of Maternal Lament in the Context of the Syrian Refugee Crisis." Paper presented at the American Academy of Religion Annual Meeting, San Antonio, New Mexico, November 2016.

24 Katrin Bennhold, "On Perilous Migrant Trail, Women Often Become Prey to Sexual Abuse," The New York Times, n.p. Cited 26 March 2017. Online: https://www.nytimes.com/2016/01/03/world/europe/onperilous-migrant-trail-women-often-become-prey-to-sexual-abuse.html? $r=0$

25 Tennenhouse, "Low Places Where Grace Abides."

26 lbid.

27 Kathleen M. O'Connor, "How Trauma Studies Can Contribute to Old Testament Studies," in Trauma and Traumatization in Individual and Collective Dimensions: Insights from Biblical Studies and Beyond, ed. Eve-Marie Becker, Jan Dochhorn and Else Holt (Göttingen: Vandenhoeck \& Ruprecht, 2014), 213.

28 O'Connor, "How Trauma Studies Can Contribute to Old Testament Studies," 214

29 Elizabeth Boase, "The Traumatized Body: Communal Trauma and Somatization in Lamentations," in Trauma and Traumatization in Individual and Collective Dimensions: Insights from Biblical Studies and Beyond, ed. Eve-Marie Becker, Jan Dochhorn and Else Holt (Göttingen: Vandenhoeck \& Ruprecht, 2014), 207. 
30 Boase, "The Traumatized Body," 206. Boase, however, points out complicating faction in that "a woman's body is not a man's body, and so the invitation to enter the pain of this body is present, but not assumed". lbid, 207.

31 Ibid, 207. Cf. also Christl Maier's argument that "this representation helps the initial audience ... to embed their individual suffering into the fate of the community. Their personal story becomes part of the larger story and thus gets national significance". Maier, "Lost Space," 194, cited in Boase, "The Traumatized Body," 207.

32 Cf. the important work of Deryn Guest, "Hiding behind the Naked Women in Lamentations: A Recriminative Response," Biblical Interpretation 7/4 (1999): 413-448.

33 Gafney, "Princess Propaganda."

34 O'Connor, "How Trauma Studies Can Contribute to Old Testament Studies," 213.

35 Maier, "Listening to the Trauma of Refugees in Jeremiah 44," 6. Maier furthermore reminds us of the vibrant community in Egypt, the military colony of Elephantine, which points to the survival of the refugee community in Egypt. Maier, "Listening to the Trauma of Refugees in Jeremiah 44," 7.

36 bell hooks, Yearning: Race, Gender, and Cultural Politics (Boston: South End Press, 1990), 41-50. 


\section{THE RAPE OF THE LEVITE'S CONCUBINE AND KAROO MOOSE Pedagogical Tools in Transforming a Rape Culture}

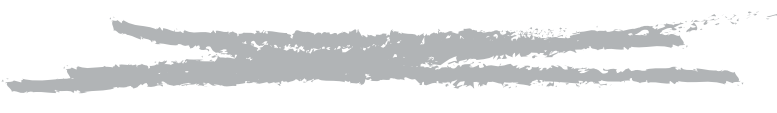

Renate van der Westhuizen

(with L. Juliana Claassens)

Faculty of Theology

Stellenbosch University ${ }^{\top}$

\section{Introduction}

Africa's girl children are suffering under the continual and relentless scourge of rape and sexual assault. Not only are young women being raped in alarmingly great numbers, but fear from being "raped" a second time by the criminal justice system is responsible for the fact that only an estimated one in 20 rape cases is reported with very few reported cases ending in conviction. ${ }^{2}$ One of the reasons for this pandemic that not only violates our young girls, but also keeps other women in a state of fear, is the prevalence of a long tradition of rape myths that have permeated the legal system as well as society.

In this essay, I propose that education, particularly in a school setting, is vital to help stop the tide of gender-based violence. In conversation with insights from scholars like Catherine MacKinnon and in our South African context Louise du Toit, I argue that it is very important for high school children to come to understand rape as having the same devastating effects on a person as torture. A redefinition of rape as torture will make it possible to challenge misguided attitudes amongst our students that tend to view crimes committed against women as insignificant, petty and irrelevant. I show in this essay how biblical stories that narrate rape such as the one told of the gang rape and murder of the Levite's concubine in Judges 19, as well as contemporary dramas like Karoo Moose that tells the story of the rape of a 15-year-old heroine, Thozama, may serve as important pedagogical tools, which on the one hand could help students realise the effect of rape on individual victims but also on communities as a whole, and on the other hand strengthen students' ability to recognise and confront sexual violence. 


\section{The Problem of Rape in Schools}

It is not easy to obtain exact statistics on incidents of gender-based violence, particularly in a school setting. The apathy and antagonism of the police and legal authorities particularly regarding black women during the apartheid era, still prevents some women from reporting these crimes. In addition, many women and girls fear reprisals, social stigma and ostracism from their families and communities if they dare to report an act of gender violence.

In the title of her 2015 book on rape in the South African context, Pumla Dineo Gqola describes rape as "A South African Nightmare".3 Indeed South Africa has been labelled as the rape capital of the world with one of the highest numbers of rape incidents per capita. ${ }^{4}$ Rape permeates every part of a women's life and, although we condemn it, it is still evident. There is something entrenched in the fabric of our society that has not been addressed properly.

Next to the family, the most important institution in a young child's life is the school. On average a child spends seven hours a day at school. The school is meant to be a safe space for all, but the reality is that many South African girls encounter sexual violence and harassment at schools on a daily basis. A study conducted by Community Information, Education and Transparency Africa found that one in every three Johannesburg schoolgirls had experienced sexual violence at school. Of these, only $36 \%$ of the girls said they had reported the episode to someone. ${ }^{5}$

Despite the claim that gender-based violence is rife in South African schools, there are no national studies that have calculated the precise extent of the problem. Statistics on sexual violence against children are vague, yet there are indications that shed light on the problem. One such example is Childline ${ }^{6}$ that notes a $400 \%$ increase in the number of reported cases of child sexual abuse over the past ten years. ${ }^{7}$ Adding to this grim figure, the Crime Information Analysis Centre of the South African Police Service stated that the three most common crimes committed against children were rape, attempted rape and assault with the intent to do grievous harm.

Human Rights Watch reports that girls are being attacked in school toilets, in empty classrooms and hallways, in hostel rooms and on the playground. These findings suggest that the girls interviewed by the Human Rights Watch feel at risk to be attacked practically in any place on the school grounds and at any time. Some of these girls interviewed by the Human Rights Watch described being persistently harassed by boys in their schools. The harassment ranges from being touched inappropriately to actual rape and many of these cases are reported to take place in plain sight of the teacher. ${ }^{8}$

From personal observations, I can confirm the claims made by these girls. Being the deputy principal at a local school, I am responsible for most of the discipline procedures in our 
school. To mention only one of the many cases that I had to deal with: On one occasion, a teacher was assisting a 12-year-old boy with extra Mathematics. He suggested to the teacher that he would do all his work if she would show her breasts to him. The teacher explained why this is not appropriate and left the class to make a few copies at which time the boy started masturbating in class in front of a classmate. When this matter was discussed with the boy's father, he casually noted that he had done the same to one of his cousins.

Already in Primary School the alarm is being raised. Children as young as nine are playing a game called "Rape, rape," in which schoolboys imitate rape with girls whom they chase and catch. During the game the girls are given a chance to run away from the boys, but when the girl is caught, the boy pins her down on the ground and simulates rape for up to twenty seconds. Games like these make rape seem normal and desensitise young children to the horror of rape. ${ }^{9}$

In an article titled "Grade 2 boys gang rape girl (8)" in the The Daily Sun on Thursday 20 August 2015, we see just how widespread the problem of sexual violence is in schools with even very young children being targeted. It was reported that Grade 2 students watched how a girl was "gang raped" by boys aged seven to ten at a primary school in Vosloorus. After the teacher left the classroom, a ten-year-old boy ordered the girl to lie down and then six of them raped her. The boys forced her to open her legs by stabbing her with pens and pencils.

Schools ought to be an environment for safe learning, offering an education and an opportunity to instil respect for human rights. However, as Burton rightly points out, "there is increasing concern within South Africa that primary and secondary schools are the sites of widespread violence." According to research done by the Human Rights Watch, one of the most fundamental challenges to learning for many learners is the risk of violence at school. These studies illustrate that teenage girls are predominantly susceptible to genderbased violence in the school environment. ${ }^{10}$

The tolerance of gender-based violence in South African schools is a grave form of discrimination that compromises the educational opportunities, especially for girls. It is girls, in particular, who suffer from sexual violence and harassment in schools. School girls in South Africa on a regular basis are assaulted, sexually harassed, abused and even raped by their classmates and, in certain instances, also by their educators.

Gender violence associated with school often results in absence from school as learners become too fearful to attend or students try to avoid going to school in an attempt to avoid the possibility of violence. This is predominantly important in a country where the completion rate for learners from Grade R through to Grade 12 is less than $50 \%$. Related to this - and often precipitating school dropout - is that school violence often results in a decrease in educational performance as victims battle to focus on content and on their 
school work in general. ${ }^{11}$ In addition to the emotional and physical consequences, sexual violence can also disrupt the education of students, because sexual violence often leads to absenteeism, underperformance and early dropout. Indeed, sexual violence in schools has definite social and economic consequences in South Africa as the victims of sexual violence have less opportunity to become economically independent.

The problem is that rape is not taken seriously enough in the context in which I teach, in the area where I live, in the circles which I move in, and in the society where we live. Recent theories of rape increasingly view rape in terms of torture and even though this topic has been discussed in academic circles, I am proposing that this way of speaking about rape has not yet trickled down to the rest of society and ought to become the norm when speaking about rape - also and especially in the school context in which I find myself. We must see rape as having the same effects on a person as torture. Rape as torture ought to become part of the vocabulary in our everyday discussion of rape.

\section{Redefining Rape as Torture}

Louise $\mathrm{Du}$ Toit ${ }^{12}$ argues that when one reads rape as torture, one will understand some of the elements of rape better. She, therefore, discusses four ways in which rape can be compared to torture.

\section{Fear}

The first comparison between rape and torture can be seen in the way in which the instilling of fear or terror in a defined section of the population translates into power-political gain for another section of the population. The fact that women and children are scared of getting raped by men helps to create and maintain a gender hierarchy in South Africa. Women cannot be fully present in South Africa, because they walk around with the fear of possibly being a victim. They make choices on the basis of safety. A woman, for example, will not go jogging after dark, because she is too scared of becoming a victim of rape. There is little distinction regarding the category of women chosen for rape. No-one is safe. From a very young age, women are taught not to trust anyone. This influences the type of relationships a woman can form with other people. Women are usually hesitant, trusting of other people and also the goveranment. There are far too many horror stories of women being assaulted and raped by officers of the law. Ironically, it is the same law that is meant to protect you or come to your aid when you find yourself in an unsafe situation that is responsible for these women's violation. As she argues, "the fact then that women are raped on a large and seemingly uncontrollable scale without the authorities taking a strong stand on all policy levels, translates for ordinary South African women into pervasive fear, systematic (contagious) humiliation, and incapacitation."13 


\section{Trauma}

The second comparison between rape and torture is the fact that both rape and torture can be seen as a traumatic event. Du Toit argues that people are currently underplaying the trauma involved in a rape case, because people still see rape as something bad that happens to women. By doing this, people make rape a women's issue. Rape victims - as with torture victims - testify that rape and torture tear apart the lived wholeness of their existence. Their sense of time and space is disrupted. They are aware of both a time and a space that existed before the rape, but view both that time and space as damaged and no longer believable. As argued by Du Toit: "Their self, their life story, and their bodily autonomy all become undone or unravelled by the rape and there is a destruction of the core attitudes necessary for psychological survival such as 'basic trust' and 'primitive omnipotence." ${ }^{14}$ Victims of rape and torture have to rebuild their lives. The trauma of these life-changing events captures the victim in an all-consuming fear and terror dictated by memories of the event. Victims of rape and torture typically show symptoms of post-traumatic stress disorder. The self of the victim is destroyed to such a point where she becomes dehumanised. The effects of rape and torture are not contained within the act. They distort what comes after the event as well. The victim of rape may believe that she was never really in control of her life to begin with.

\section{False Motive}

The third comparison between rape and torture according to Du Toit is the fact that both acts hide behind a false motive. Findings paint the torturer as the vulnerable party with a need that only the victim can fulfil. In the same way, the rapist likes to see himself as vulnerable, because in him exists a need that was created by the woman and that only the woman can fulfil. "But ironically, the pretended vulnerability of both torturer and rapist serves also to cover up the real vulnerability or need - the actual motive for the torture and rape." ${ }^{15}$ Whichever way one looks at it, the real motive for both torture and rape is power. The false motive for rape is ample - the legacy of apartheid, male aggression and militarisation of our male youth, the appearance and behaviour of women, or the violent culture in which we live. All of these motives have some truth hidden in them, but above all, men rape to feed their desire for power.

\section{Performance}

Rape also shares with torture its sense of being a performance - with a stage, a theatre and a production room. Therefore, we see how the phenomenon of gang rape also relates to the theory of rape as torture and an act of performance. The rapist often finds it important to have a crowd and this idea fits in with the idea of rape as torture in which the rapist has to prove his manhood by inflicting pain on or humiliating his victim. If we compare rape to 
theatre, the penis will play the role of the protagonist. Everything works together to create a spectacle of power. The woman's body provides the stage and the props. Du Toit has rightly stated:

If extreme bodily pain reduces the prisoner to raw bodily existence, and if his world is destroyed to the exact measure that his body enlarges to fill his universe, then in rape, something similar happens. In rape, the woman's body comes to fill her universe and destroy her world, her body itself turning into her enemy and into the rapist's weapon. Through societal prejudice about women's complicity in rape, through being faced with death and complying with the rapist's demands out of fear of death, and through extreme sexual humiliation, the woman or child is brought to a point of profound self-alienation and intense self-hatred. A rift is torn open between her will or desires, her deepest intentions and fears on the one hand, and her actions on the other. As in torture, the person being raped often loses control of her bodily functions. During and after rape and torture, victims experience an acute loss of control over their lives, their bodies, their voices. This loss is essentially a loss of world and of a prior, integrated sense of self. ${ }^{16}$

The above description by Louise du Toit is illustrated well by Alison Botha's ${ }^{17}$ description of her horrific rape in her book I Have Life:

When he finished he slithered up towards my breast and then he latched on to it like a leech. I stared down at him. It was an oddly disconnected moment. Here was this strange man at my breast. It was such a violation of my body, my personal space. I could see him doing it and it revolted me. He looked up, smiling at the purple 'love-bite' he had left behind. Then he moved up and kissed me. There was an over-whelming stench of nicotine. His breath was sour and he probed my mouth with his tongue. 'You have the nicest fanny,' he whispered. I was disgusted by the intimacy of his remark. Then he raped me. As it happened I realised that I was moist and I was horrified. I felt that my body had betrayed me completely. ${ }^{18}$

Allison's story made the headlines, because it was a brutal attack and she survived. One of the big issues about South Africa is that, because gender-based violence is so omnipresent, it usually does not make the news, unless it is exceptionally dramatic. The fact that we have normalised rape has caused the population to become desensitised to incidences of rape.

$\mathrm{Du}$ Toit states that the fact that rape is so normal in South Africa testifies to one of the paradoxes at the heart of the political transition. She argues that "in a previous dispensation rape was justified to an extent by the legitimacy of the struggle, but now that a legitimate government is in place, the very same acts of rape must no longer be viewed as political actions", because that would undermine the new dispensation's claim to legitimacy and so they come to be treated as 'purely personal', criminal actions undertaken by symbolically marginalised individuals. ${ }^{19}$ During the apartheid struggle, a woman's rape was justified in terms of the struggle. It was seen as a weapon of terror, an instrument of torture or a way in which one could reward a soldier, and it was done by both sides of the struggle.

Rape is a form of torture. The rapist does not need the same tools as the torturer; he does not need a torture chamber and it does not even have to happen in a time of war. 
Examinations ${ }^{20}$ of rape victims have shown that the trauma a victim of rape experiences is comparable to that of torture victims. Rape and torture have the same two targets: a people and its civilisation. Whenever a person is raped, wherever it happens and whatever form it takes, rape - like torture - is a crime against humanity.

\section{Torture becomes Terror}

The word "terrorism" invokes images of religious extremists strapping a bomb to their chests and walking into a public place, killing numerous innocent civilians. It also invokes images of countries terrorising other countries, but there exists another type of terrorism, a terrorism that pervades our culture and that we have learned to live with as if it is the way it should be. Rape has come to be seen as something to be condemned, but never to be addressed in such a way that sees an end in sight.

Scholars like Catherine MacKinnon ${ }^{21}$ and Louise du Toit have helped us to understand that rape ought to be understood as a form of torture. In one respect, making the link between rape and torture is a conscious strategy that helps to raise the profile of a previously trivialised crime primarily affecting women and then to open access to remedies that were otherwise not available. By understanding and defining rape as torture, it is possible to counteract the gendered division that exists in society today. According to Claudia Card, "violence, or the threat of violence, against innocent civilians is the most obviously problematic feature generally associated with terrorism." 22 Rape, like terrorism, targets women and girls of all ages. The most prominent feature of these targets is their gender. When rape is a weapon, it is not merely a gigantic hate crime against women, but rather an act of terrorism. As we have seen earlier in this essay, rape controls women's behaviour through fear. Torture, terrorism and rape tame their victims by relying on the debilitating effects of fear. Torture becomes terrorism when some are tortured to get an entire group to submit. The pervasiveness of rape and violence against women creates an environment of terror and the awareness that strangers, friends, even family members could be possible attackers.

\section{Teaching Rape in Schools?}

How then does one address this growing problem of gender-based violence in our schools? In the course of this study, I have become convinced of the utmost necessity for schools to reach young students with specifically designed programmes that address sexual violence at an earlier stage before expectations and attitudes about gender relationships are well developed.

Nonetheless, in spite of this conviction that South African schools ought to transform society's gendered standards and ideas, more often than not schools seem to mirror the very same gendered unequal ways of thinking and acting. 
In addressing and attempting to eradicate gender violence in South African schools, a whole-school approach involving school management, teachers, pupils and the curriculum is necessary to guarantee that the messages are constant and reinforced by teachers and students as well. Teachers have the tools to be the key instruments of change. However, teachers are also gendered beings, and for teachers to be effective in teaching about sexuality, they need to understand and confront their own attitudes and experiences relating to gender violence. Considering that some teachers are perpetrators of abuse and other teachers may be victims of abuse, it is imperative that strategies to address gender violence in schools recognise and address experiences of teachers and pupils alike so that positive and joint relationships can be encouraged.

As a religious studies educator currently working in a school context, I believe that literature, including biblical stories that portray the terrifying reality of rape, can serve as an important pedagogical tool that strengthens our ability to confront sexual violence.

In the following section, I will show how educators can potentially use literature as a pedagogical tool to teach students about gender-based violence. Teachers understand all too well the power of fiction in order to effect change. By means of illustration, I will briefly introduce two examples from literature - one contemporary and one from the biblical witness - that may serve to create awareness among both female and male students of the terrorising reality of rape. Thus, we shall consider the play Karoo Moose that portrays the unspeakable rape of a young baby, as well as the equally horrific story told in Judges 19-21 of the brutal rape of the Levite's concubine that continue into the violent abduction and rape of a multitude of young women. Both stories could serve as a conversation starter to help students see the reality of rape, to gain theoretical perspectives on rape and to empower students to resist rape and thereby transform a rape culture through education on genderbased violence. Studying stories of violence against women can allow students to discuss probable causes and effects of violence against women.

\section{Karoo Moose by Lara Foot Newton ${ }^{23}$}

Prescribed works such as Karoo Moose can be employed by educators not only as a means to cover curriculum topics, but also as a way to create a platform in which the dialogue of gender violence can be openly discussed. The play Karoo Moose, which has been workshopped (a theatre-making process involving research, improvisation, discussion and collaborative text writing) and created by director Lara Foot Newton, tells the story of two families with the focus on the life of a young girl, Thozama. Thozama lives with her grandmother, Grace, and her two younger siblings in a remote town in the Karoo. Thozama's father, Jonas Vilakazi, is an absentee father which introduces one of the underlying themes of the play, namely the absence of the father figure in Africa's households. 
The other family in the play is the Van Wyk household. Mrs Van Wyk lives with her son Brian. Mr Van Wyk is in an institution and we later learn that Brian's sister committed suicide, because she could not overcome the fact that her father repeatedly raped her. Grace, the grandmother in the first family, works as a domestic worker in the Van Wyk household and so Foot Newton links the two households, making us aware of the prevalence of social problems in both families regardless of race or social class.

The father in the story, Jonas, is shown as drinking and smoking dagga with his friends. When he loses a bet on a soccer game, he does not have money and gives up his daughter Thozama as a settling prize. One of Jonas' friends, Khola, then proceeds to rape Thozama. The response of the grandmother, Grace, is to wash her grandchild and tell her that she is a woman now.

The story continues with Thozama falling pregnant with Khola's baby and with Khola later also raping Thozama's sister Quinnie. When Thozama subverts the traditional norm and humiliates Khola in front of the locals, Khola reacts in the most shocking way by raping Thozama's baby - his own child.

This disturbing play is one of the prescribed texts for the South African school system in Dramatic Arts. This play serves as the ideal platform to cultivate animated conversation on the reality of rape, gender roles, masculinity and the patriarchal system in establishing a rape culture in which violence against women is considered normal. When teaching this play, I have found that learners typically respond with outrage to this play, becoming furious with the character Jonas and the fact that Grace merely pretends that the acts of sexual violence in her house are not happening.

Students ask questions about the reason for rape, which thus create the ideal opportunity to re-teach students on the reality of rape in South Africa, utilising some of the theoretical perspectives included in this study. In particular, it is helpful to draw students' attention to the way gender roles function in this play. For instance, Khola rapes Thozama's baby only after she humiliates him in front of the villagers, thus reclaiming his power as the dominant party. The fact that the Van Wyk family never speak about what had happened in their household further demonstrates the issue of shame surrounding rape within the family context, which explains why so many victims are suffering without justice.

Thozama asks her grandmother whether Mrs Van Wyk ever speaks about her daughter. Grace responds by saying, “No, we pretend it didn't happen." Thozama then utters the extremely important response, "But it did." 24

The power of Karoo Moose lies in the structure of the text. Learners will spontaneously start to question the values portrayed in the story, thus creating their own platform and ideal circumstances to educate the youth about these social issues within the context of the South African classroom. 


\section{Rape as Torture in Judges 19-21}

Another story that also has great potential to help students understand the extent of violation women can suffer at the hands of men is the biblical story of the rape of the Levite's concubine as told in Judges 19-21. A reading of Judges 19-21 through the theoretical lens of Rape as Torture recognises that patriarchy permeates the past and present. It draws the reader's attention to the persecuted woman and it sees the concubine's namelessness as related to all women who suffer sexual violence.

When I recently taught Judges 19-21 in my Grade 10 class, I started the lesson by asking the students how they would define rape. The first boy responded by saying that "his girlfriend was gang raped by a troupe of mime artists. They performed unspeakable acts on her", at which point the entire class burst out in laughter. I realised that they did not laugh because it is an uncomfortable topic; they laughed because they do not see rape as something horrible. I tolerated the laughter, and proceeded to discuss the rape stories in the Bible. The class was astonished to hear about the rape stories and they all agreed that they had never before heard any of them, which created an opportunity to discuss the reasons why they had never heard about them. This created the perfect platform to discuss patriarchy and the effects thereof. The discussion moved beyond simple gender discrimination to a lively discussion on the unfortunate reality of men earning more money than women for doing the same job. The discussion moved to a place where the students realised that patriarchy was created to keep women in a place of submission.

After two weeks of discussing patriarchy and the role of women in biblical times, we started reading Judges $19 .{ }^{25}$ At this stage, the students were sensitive to the fact that not much attention was paid to women and, therefore, they immediately noticed that the narrator spends very little time on the rape narrative, and they also noticed the silence of the concubine. We spent another week comparing the rape of the concubine to newspaper stories of this year. Needless to say, we found rape narratives every single day. The students were shocked at the pervasiveness of rape, but they were even more shocked that they had never noticed just how common rape is.

In an article "Towards a Logic of Dignity: Educating Against Gender-Based Violence" in the International Handbook on Learning, Teaching and Leadership in Faith-Based Schools, Juliana Claassens suggests that educators enlighten students about gender violence by using a biblical text that narrates rape such as Judges 19-21, which includes strategies such as helping students - both boys and girls - to recognise the reality of sexual violence in their communities, that is, to see rape as rape. Claassens further shows that biblical narratives can be used to teach boys to embrace other forms of masculinity, as well as teach the young ones important skills such as critical thinking, empathy and compassion. ${ }^{26}$ 
From the interpretation of Judges 19, it has become clear that men have control over a woman's body and the woman actually belongs to a man. She is his property. In Judges 19-21, the reader can observe that even their sexuality was under the control of a virgin girl's father and a wife's husband. It is for this reason that the old man did not think twice to offer the two females - his daughter and his female guest - to the men of Gibeah.

Claassens identifies several themes that emerge from Judges 19-21 that can be utilised as a pedagogical tool in schools. For instance, Claassens notes that the reading of the narrative has a definite shock value and the narrative has the ability to draw one in. The learners will be shocked by the woman's plight and disgusted by the Levite's treatment of his wife. Furthermore, the narrative has the ability to offer teachers and learners the opportunity to speak about many similar stories in South Africa and also their own. Lastly, she proposes that using Judges 19-21 in the classroom might be a helpful pedagogical tool for teaching learners empathy, thus drawing them into the narrative to identify with the numerous victims of violence. ${ }^{27}$

\section{Conclusion}

Pumla Gqola maintains that "the grip of violence is tightening around our collective necks" and if we do not break the grip, we will suffocate and suffer to death. ${ }^{28}$ I contend that the only way to loosen the grip rape has around our necks is to fully acknowledge the problem and expose the seriousness of rape by not tolerating sexist jokes or choosing to ignore the stories around us. But, even more importantly, we are called to take action. Rape is driven by power but, because of the silence of society, it has become an act of indulgence. The fact that rape happens often and that we are used to the news cannot and should no longer influence our ability to see rape for what it is - torture.

As educators we have the opportunity to raise awareness regarding the widespread nature of gender-based violence. In this regard, the story of the rape of Levite's concubine in Judges 19 as well as contemporary dramas like Karoo Moose may help students to understand the gravity of this South African nightmare. By means of these rape texts, high school children may come to understand the devastating effects of rape, not only for the victim but for the community as a whole, that have been described by feminist theorists as torture. However, beyond growing in understanding regarding the seriousness of this problem, students are also challenged and equipped by these lesson plans to find ways to turn their anger into action, so becoming agents of change themselves. 


\section{Bibliography}

Burgess, Ann and Holmstrom, Lynda. "Rape Trauma Syndrome." The American Journal of Psychiatry 131/9 (1974): 981-986. https://doi.org/10.1176/ajp.131.9.981

Burton, Patrick. "Dealing with School Violence in South Africa." Centre for Justice and Crime, CJCP Issue Paper No. 4, 2008.

Card, Claudia. Confronting Evils: Terrorism, Torture, and Genocide. Cambridge, MA: Cambridge University Press, 2010. https://doi.org/10.1017/CBO9780511782114

Claassens, L. Juliana. "Towards a Logic of Dignity." Pages 6-7 in The International Handbook on Learning, Teaching and Leadership in Faith-Based Schools. Edited by Judith D. Chapman, Sue McNamara, Michael J. Reiss and Yusef Waghid. New York: Springer, 2014.

Du Toit, Louise. "A Phenomenology of Rape: Forging a New Vocabulary for Action." Pages 260-266 in (UN)Thinking Citizenship, Feminist Debates in Contemporary South Africa. Edited by Amanda Gouws. Burlington, VT: Ashgate Publishing, 2005.

Du Toit, Louise. A Philosophical Investigation of Rape: The Making and Unmaking of the Feminine Self. New York: Routledge, 2009.

Foot Newton, Lara. Karoo Moose. London: Oberon Books, 2009.

Gqola, Pumla. Rape: A South African Nightmare. Auckland Park: MFBooks Joburg, 2015.

Haffejee, Sadiyya. "Waiting Opportunities: Adolescent Girls' Experiences of Gender-based Violence at Schools." Research report written for the Centre for the Study of Violence and Reconciliation Genderbased Violence Programme, 2006.

Human Rights Watch. "Scared at School: Sexual Violence against Girls in Schools." United States of America, 1 March 2001. Cited 12 November 2018. Online: https://www.hrw.org/report/2001/03/01/scaredschool/sexual-violence-against-girls-south-african-schools\#

Jewkes, Rachel. "Intimate Partner Violence: Cause and Prevention." The Lancet 359 (2001): 1423-1429. https://doi.org/10.1016/S0140-6736(02)08357-5

Jewkes, Rachel and Abrahams, Naeema. "The Epidemiology of Rape and Sexual Coercion in South Africa: an Overview." Social Science \& Medicine 55 (2002): 1231-1244. https://doi.org/10.1016/S0277. 9536(01)00242-8

MacKinnon, Catharine. Only Words. Cambridge, MA: Harvard University Press, 1993.

News24. "Western Cape pupils play 'rape, rape' game," 18 August 2014. Cited 12 November 2018. Online: https://www.news24.com/SouthAfrica/News/Western-Cape-pupils-play-rape-rape-game-20140818

Thamm, Marianne. I Have Life: Alison's Journey. London: Penguin Books, 1998.

Van Niekerk, Joan. "Gang Rape of Children: The Context and Dynamics of Gang Rape from a Child Victim Perspective and Management Issues for Child Protection Professionals." Children First 6/44 (2002): 20-23.

Vetten, Lisa. "Rewriting the Script around South Africa's Rape Statistics," The Conversation, June 19 (2015). Cited 11 December 2018. Online: http://theconversation.com/rewriting-the-script-around-south-africasrape-statistics-40541

Wood, Katharine and Jewkes, Rachel. "Love is a Dangerous Thing: Micro-dynamics of Violence in Sexual Relationships of Young People in Umtata." CERSA (Women's Health) Technical Report. Pretoria: Medical Research Council, 1998.

\section{Endnotes}

1 Renate van der Westhuizen is a graduate of the MTh Gender, Health and Theology programme of the Faculty of Theology, Stellenbosch University. This essay is based on her MTh thesis, "Rape as Torture: Re-reading the Rape of the Levite's Concubine in Judges 19" (Stellenbosch University, 2015).

2 Numerous studies verify the finding that only half of all respondents who experienced rape reported the incident to the police. Police statistics also show that $47,6 \%$ of the rape cases reported to the police were referred to court after investigation. But of the cases referred to court, 45, $6 \%$ were withdrawn in court and a further $4,5 \%$ settled out of court. Of the 22,121 reported cases that went to court in 2016, only a fifth $(19,8 \%)$ resulted in the conviction of the accused (Statistics South Africa, Victims of Crime Survey, 2016), 11.

3 Pumla Dineo Gqola, Rape: A South African Nightmare (Auckland Park: MFBooks Joburg, 2015). 
4 Lisa Vetten, "Rewriting the Script around South Africa's Rape Statistics," The Conversation, June 19 (2015). Cited 11 December 2018. Online: http://theconversation.com/rewriting-the-script-around-south-africasrape-statistics-4054 1. Cf. also R. Jewkes and N. Abrahams, "The Epidemiology of Rape and Sexual Coercion in South Africa: An Overview, Social Science \& Medicine 55 (2002): 1231-1244.

5 Cf. also the increase of sexual harassment reports made by female students that indicate that gender equality is not practised in schools. For example, it has been reported recently that more than $30 \%$ of girls are raped at school (SACE, 2011, p. 7) CIET Africa. "Building the Community Voice into Planning. Beyond Victims and Villains: The Culture of Sexual Violence in South Johannesburg." (Southern Metropolitan Council, 2000).

6 Childline is a non-profit organisation that runs a helpline for children and provides therapeutic services and advice to child victims of abuse and their families.

7 Joan van Niekerk, "Gang Rape of Children: The Context and Dynamics of Gang Rape from a Child Victim Perspective and Management Issues for Child Protection Professionals," Children First (August 2002).

8 Human Rights Watch, "Scared at School: Sexual Violence against Girls in Schools." United States of America, 1 March 2001. Cited 12 November 2018. Online: https://www.hrw.org/report/2001/03/01/ scared-school/sexual-violence-against-girls-south-african-schools\#

9 News24, "Western Cape pupils play 'rape, rape' game," 18 August 2014. Cited 12 November 2018. Online: https://www.news24.com/SouthAfrica/News/Western-Cape-pupils-play-rape-rape-game-20140818

10 Katharine Wood and Rachel Jewkes, "Love Is a Dangerous Thing: Micro-dynamics of Violence in Sexual Relationships of Young People in Umtata," (CERSA [Women's Health] Technical Report, Pretoria: Medical Research Council, 1998).

11 Patrick Burton. Dealing with School Violence in South Africa. Centre for Justice and Crime, CJCP Issue Paper No. 4, 2008.

12 Dr Louise du Toit is an Associate Professor in the Department of Philosophy at the University of Stellenbosch. A Philosophical Investigation of Rape: The Making and Unmaking of the Feminine Self (Routledge) was published in 2009. In that same year, Du Toit served as Guest Editor for the November 2009 special edition of Philosophical Papers that examined 'The Meaning/s of Rape'. She has published widely on the theme of rape and sexual violence, relating this to phenomenological analysis, feminist legal theory, transitional justice, philosophy and literature and African thought.

13 Louise du Toit, "A Phenomenology of Rape: Forging a New Vocabulary for Action," in (Un) Thinking Citizenship: Feminist Debates in Contemporary South Africa, ed. Amanda Gouws (Aldershot: Ashgate and UCT Press, 2005), 260.

14 lbid, 80.

15 lbid, 264.

16 Ibid, 266.

17 In 1994, Alison Botha was raped by two men who then stabbed her more than thirty times with a knife and tried to slit her throat more than 16 times. She was left for dead in a veld. She had to gather her intestines and tuck them into her shirt, while she held her head on her body with another hand.

18 Marianne Thamm, I Have Life: Alison's Journey (London: Penguin Books, 1998).

19 Du Toit, "A Philosophical Investigation of Rape," 16.

20 A.W. Burgess and L.L. Holmstrom, "Rape Trauma Syndrome," The American Journal of Psychiatry 131/9 (1974): 981-986.

21 Catharine MacKinnon argued that rape should be classified as torture in 1993 at the same time that the international community was facing up to the realities of mass rape in the former Yugoslavia. Feminists were acting against what was perceived to be the lack of interest in bringing perpetrators to justice and the failure to recognise the devastating, harmful nature of rape. MacKinnon argued that all rapes should be reconceived as 'torture', with the consequent positive impact this would have on legal recognition of the harms and international commitment to the prosecution and eradication of rape. See more on this in Catharine MacKinnon, Only Words (Cambridge, MA: Harvard University Press, 1993).

22 Claudia Card, Confronting Evils: Terrorism, Torture, and Genocide (Cambridge University Press, 2010$), 127$.

23 Lara Foot Newton is a South African Theatre Director, producer and playwright. Her critically acclaimed film Karoo Moose has won 14 awards. She is the first female Chief Executive of the Baxter theatre in Cape Town. She has been recognised nationally and internationally for her unique vision and the courage with which she approaches her work. Karoo Moose is written under the name Lara Foot Newton and will hence be cited as such.

24 Lara Foot Newton, Karoo Moose (London: Oberon Books, 2009). 
25 One should note that Judges 19-21 cannot be taught as a single unit. Before an educator can even start to look at the narrative of rape, one will have to discuss issues such as patriarchy, masculinities and rape myths. It is also important to show the learners that all of these aspects are related and connected. Once learners grasp these concepts, the educator can start with the discussion of Judges 19-21.

26 L. Juliana Claassens, "Towards a Logic of Dignity," in The International Handbook on Learning, Teaching and Leadership in Faith-Based Schools, ed. Judith D. Chapman et al. (New York: Springer, 2014), 6-7.

27 Claassens, "Towards a Logic of Dignity," 6-7.

28 Gqola, Rape, 66. 


\section{THROUGH AN IMMIGRANT'S EYES Effects of Migration on Women and Children in the Light of Migration Stories in Genesis 12-50}

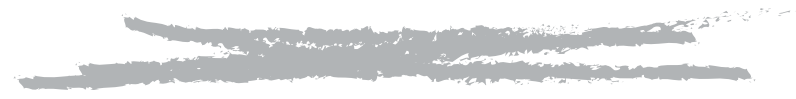

Funlola 0. Olojede Gender Unit, Faculty of Theology Stellenbosch University

\section{Introduction}

The Patriarchal Narratives in Genesis 12-50 (including the Joseph story in this case) are said to deal with the elementary foundations of human society, especially family relationships and the importance of family in society. ${ }^{1}$ Compared to the book of Exodus, which is essentially a story of migration, the focus of the Patriarchal Narratives is on the patriarchs and their family relationships, but we can say that the backdrop for these stories is what Westermann calls "the patriarchs' migratory way of life.". Unlike the book of Exodus, which relates the mass migration of a people out of Egypt on their way to the land of Canaan, the migrations in Genesis have to do with families or individuals and they seem to be informed primarily by the pastoral nomadic lifestyle of the patriarchs. In fact, Nahum Sarna refers to the migration of the patriarchs as a "pastoral migration." The patriarchs Abraham, Isaac and Jacob were all pastoralists (Gen 13:2-7; 26:14; 30; 47:3). Therefore, several itineraries are reported in the narratives, which confirm the migratory nature of their lifestyle.

Engaging with the stories of migration as narrated in Genesis 12-50, I reflect in this essay on the effects of migration on women and children in the light of contemporary migrations in different parts of the globe, particularly from Africa to Europe and the Americas. When migrating from one place to another, men in the ancient world sometimes used women and children as a shield, thereby putting their lives in jeopardy. However, in another sense, these two groups, which were generally viewed as vulnerable, were also shielded by men from the hazards that accompanied migration in their time. It is argued that on a sociopsychological level, the plight of women and children in families that undergo either forced or voluntary migration from Africa should be reconsidered by society. Due to my social location as a West African female resident in South Africa myself, I readily identify with issues of migration in the biblical text. And I wish to demonstrate that a gender-sensitive 
reading of biblical narratives in a pedagogical setting helps to tease out latent issues in the text that tend to be overlooked by traditional readings. Retelling biblical narratives in a classroom setting as I have attempted in this essay is not only hermeneutically helpful, it also has contemporary relevance.

In what follows, I will present a brief outline of the contemporary view of migration, tease out the instances of migration in the Patriarchal Narratives, relate the plight of women and children involved in those migrations, and probe the implications of the findings in a modern context. It is important to note at this point that the migrations in the text will be approached in respect of both the movement from one place to another, as well as the settlement of the migrants in a particular location.

\section{Migration - a Brief Note}

The term 'migration' is used to refer to the movement of an individual or a group from one territory, locality, country or society to another and should be distinguished from travel for the purpose of visit, because it involves settlement, whether temporarily or permanently. Migration is an age-old and universal phenomenon that is not unique to our time. All through history, people have engaged in mass or individual migrations even across vast distances, ${ }^{4}$ and over long periods of time. What is unique about modern migration is the ease of transportation and access to other geographical spaces besides one's own. In contemporary migration studies, a distinction is made between voluntary and forced migrations, ${ }^{5}$ between urban and rural migrations, and between local and international migrations, among others. ${ }^{6}$ Central to all forms of migration, however, is movement.

It has been observed that various factors account for the migration of individuals and groups, some of which remain the same throughout the history of human migration. For example, economic, political, cultural, religious and ecological factors are often central to decisions to migrate. These factors are distinguished as push and pull factors. Whereas the push factors such as unemployment, political upheavals, religious persecution and natural disasters, including drought and tsunamis or earthquakes, cause people to leave their territory, the pull factors such as the prospect of better living conditions or safety draw them to a new destination. ${ }^{7}$

Contemporary migration patterns have also been linked to the idea of globalisation. Not only is migration a global trend today, scholars also talk about the globalisation of migration. ${ }^{8}$ In other words, to a large extent, "forces of globalisation" in conjunction with other socio-political factors influence migration today at the macro level. ${ }^{9}$ Thorsten sees current migration as an integral part of the globalisation process. ${ }^{10}$ Castles and Miller explain that "... migration and settlement are closely related to other economic, political and cultural linkages being formed between different countries in an accelerating process 
of globalization."11 Thus, on a global level, movement of people occurs every day from one country to another, from one society to another, from one region to another, and from one city to another.

However, what is central to our discussion is the place and plight of women in these migrations. According to Hashim and Thorsen, “... until recently women and children were typically imagined as merely tagging along behind the 'primary' male migrant... consequently, migrant women's and children's perspectives were rarely heard ..." "Recent studies have shown that women are migrants in their own right..." It is reported that over half of migrants globally are women and girls, ${ }^{13}$ and some studies have challenged the stereotype that female migrants are mere dependants on male migrants who can be classified under what some countries refer to as family unification category. The studies show that women are found in all categories of migrants, including refugees, some asylum seekers, and economic migrants, and not just as men's dependants or "tag-alongs". ${ }^{14}$ Moreover, it has been recognised that women play a significant role in labour migration today. It is argued also that the fact that many women migrate as part of a family unit should not be used to downplay their role and agency in migration. ${ }^{15}$

Furthermore, studies on female migration show that problems faced by migrant women are compounded by the fact that they are migrants and they are women. ${ }^{16}$ For example, literature on labour migration reports that previous studies have overlooked the impact of long-distance family migration on women. It shows that "the employment characteristics and quality of life of female partners often suffer as a result of long-distance family migration", which often involves some compromise and negotiations among family members, especially on issues in which there is a conflict of interests. ${ }^{17}$ In the case of children (and I do not mean to universalise the definition of childhood as a category), it has been established that parental migration sometimes has negative consequences on the health and education of the children who are compelled to move with their parent/s to a different territory. ${ }^{18}$ Notable also is that in some cultures, some underage children venture out on their own without one or both parents, and migrate to other places. It can only be expected that such children would be prone to danger.

Having shown that women and children migrate as part of family units, or independently of family; that female migrants face a double jeopardy because of their status as migrant and as female; and that women and children experience certain hazards due to migration, I will turn to the Patriarchal Narratives to consider its depiction of women and children, not only in the course of the various reported itineraries that can be classified as migration, but also as settlers in specific territories outside their original domain. Of course, this is not an attempt to imply that migrating or migrant men do not encounter problems; some do, but such problems do not constitute an immediate concern of this essay. A textual overview of Genesis 12-50 will be carried out, using not the patriarchs but the matriarchs as the point 
of departure, to evaluate the role of women in the migrations, as well as the impact of the movements and the settlement on the women and children. In view of recent trends of mass exodus of refugees and asylum seekers, and the upsurge in the number of migrant labourers to western Europe and North America, this essay seeks to make sense out of the many hazards that the women and children in such migration companies face in the light of the experiences of women and children in the migration episodes in Genesis 12-50.

\section{Genesis 12-50 - Overview of the Migrations}

\section{Sarah and Abraham - Gen 11:27-25:11}

The records of movement in Genesis 12-50 are preluded by the incident of migration in the genealogy of Terah, the father of Abram, Nahor and Haran in Genesis 11:27-32. Terah and his family were from Ur of the Chaldees, but in the course of time he lost his son Haran. No mention is made of Terah's wife or the mother of his sons. Perhaps, like Haran, she had also died. We are not told why Terah decided to emigrate, but one possibility could be that it was because of his bereavement. Terah set out for the land of Canaan with some members of his family, including his daughter-in-law Sarai and her husband Abram, but he did not make it. The group settled instead in Haran where Terah eventually died.

The story of Sarah and Abraham's movement seems to stem from that of Terah and is a continuation of Terah's dream, which was unfulfilled. In Genesis 12:1-9, in response to God's instruction and promise, and in what seems to be a chance to fulfil his father's dream, Abraham set out with the rest of the crew for the land of Canaan and settled for a while in Bethel, but continued to roam the rest of the territory. Westermann notes that the narratives in Genesis 12-25 are framed by itineraries. ${ }^{19}$ However, we note that the family was soon to be pushed out of what was supposed to be a promised land, and a land of blessings. The cause was famine, and Abram decided to relocate his household to Egypt (Gen 12:10). At that point, he and his wife had no children. In a move that would be regarded today as a retro-migration, the family later returned to the Negev, and specifically to the region of Bethel where they previously pitched their tent (Gen 13:1-4). Disputes between the herdsmen of Lot and the herdsmen of Abram caused the group to split and Lot settled in the plains of Sodom and Gomorrah, while Abram remained in the Negev and eventually moved to settle in the region of Hebron by the oaks of Mamre (Gen 13:5-18).

In the course of time, Abraham and Sarah moved their family around a bit, but the length of time they stayed in a particular place was unspecified in the narrative. For instance, they lived in the land of the Philistines, as temporary residents in Gerar and in Beersheba, eventually moving back to Hebron where Sarah later died (Gen 20:1, 21:32-34; 22:19; 23:1). However, it appears that by the oaks of Mamre was where they settled for a long time, and 
where they called home (cf. Gen 13:18; 14:13; 18:1, 33). Even then, they only had the status of the ger (resident alien) in all those places, as Abraham himself acknowledged (Gen 23:4). Only after the death of Sarah was he able to secure for the first time the title deed to a piece of land in a territory that he had dwelt in for several decades (Gen 23:3-20). On that piece of land where Abraham laid Sarah to rest, he was himself buried at his death (Gen 25:9-10). The sojourn, which had begun in the Ur of the Chaldees and which took a detour to several places, including the land of Egypt, ultimately came to a head in the cave of Machpelah near Mamre in the land that Terah, his father, only dreamt of living in.

So what was the lot of Sarah and the other women in the Abraham narratives through all these movements? At no time in the narratives of Genesis 12-25 do we see Sarah voice any opinion about the decision to move from one place to another. It seems that the dominant voice in respect of the movements was Yahweh's. It was at his prompting that Abraham moved the family from Haran to the land of Canaan (Gen 12:1-3), but the final decision to move was Abraham's and at times, he did not wait for the voice of Yahweh before they moved - for example, to Egypt (Gen 12:10). However, it is also possible that Abraham consulted with Sarah, or at least sought her consent, before making the decisions. Based on other incidents such as the decision to send Ishmael and Hagar away (Genesis 16), there are indications that Sarah was not exactly what one would call a passive wife. She had some sway in the family's decision-making processes. However, it appears that Abraham called the shots when it came to decisions to relocate (Gen 12:5). When they approached the border of Egypt, he asked Sarah to lie that she was his sister, and she did so. It is from this type of scene (cf. Genesis 20; 26) that the reader begins to notice the kind of threat and danger that awaited women, in particular beautiful women, on a migration journey. This family was trying to escape the threat of starvation due to the famine in Canaan, but unknown to its other members, other hazards besides the threat of death waited ahead. Only Abraham anticipated part of the danger that lay ahead, ${ }^{20}$ which is that the men of Egypt could try to kill him on account of his beautiful wife Sarah.

At the border of Egypt, Sarah had to lie to "the immigration officers" that she was Abraham's sister in a way that is reminiscent of what often takes place at the borders of receiving nations where intending migrants tell various lies about their intention to pay a short visit to the country. Some migrants also use fake passports and identities that portray them to be what they are not. ${ }^{21}$ It was not Sarah's idea to lie and she probably had to defy her conscience to obey her husband. She also seemed unaware that the lie would jeopardise her independence and honour, as she would soon be abducted by the king. Westermann writes in defence of Abraham's action noting that:

An insignificant man at the mercy of the powerful has only his wits for a weapon; this is true throughout the ancient world. The ruse Abraham intends to employ is based on experience with the mighty: by virtue of their power or wealth, they can get any beautiful woman they desire. ${ }^{22}$ 
However, Abraham was only interested in saving his own skin, ${ }^{23}$ and had no qualms about throwing Sarah to the dogs. Again, this act reminds one of the hundreds of thousands of women and children from the developing world who end up being sexually exploited in their attempts to seek greener pastures abroad.

It took Yahweh's intervention for Sarah to escape from the palace of pharaoh and one would have thought that after the episode in Egypt, Father Abraham would learn his lesson and show some remorse. But the scene repeats itself in Genesis 20. This time, he did not ask Sarah to lie to the people of Gerar. He did it himself telling the people that she was his sister. Again, the king of Gerar Abimelech took interest in the beautiful Sarah and sent for her and took her like David did Bathsheba (2 Sam 11:4). Luckily, the divine hand restrained Abimelech from touching Sarah. But Abraham profited greatly from that incident, both materially and financially (Gen 20:14-16).

The two incidents show that Sarah was obviously at risk each time the family relocated to a new place. They had moved from Haran to a new country where they settled in different cities at different times and moved out once to Egypt and back. But they were exposed to threats again and again. It can be assumed that if Sarah who was the most important female member of the household was exposed to that level of danger and could not be protected by Abraham, the fate of the other females in the family such as maidservants and slaves was probably worse. Remarkably, Sarah herself who had experienced first-hand the kind of hazards that women faced even in the company of men readily threw Hagar and her son Ishmael out to the wolves. Whereas other people relocated to cities and lands with better opportunities, Hagar and Ishmael emigrated to the desert. It was the best a woman without status and means could do, and in that wilderness of Paran, Ishmael would live out the best part of his youth (Gen 21:20-21).

\section{Rebekah and Isaac - Gen 24}

When his father's servant got a wife for him, Isaac was living in Beer Lahai Roi in the Negev and he was still there when his father died (Gen 24:62; 25:11). In Isaac's household, Rebekah was the immigrant, for she had relocated from her natal family in Paddan Aram to marry Isaac (Gen 25:19). She was accompanied by her nurse Deborah, and from that young age it seems she no longer saw her brother, her father and the rest of the family. As in the days of Abraham, there was also a famine in the land and Isaac wanted to follow his father's footsteps to emigrate to Egypt, but the Lord warned him not to go down to Egypt; therefore, he decided to settle in Gerar (Gen 26:6) where his parents also once resided (Gen 20:2). Clearly, one of the main reasons why people migrated in the ancient world was famine, as well as the effects of climatic changes. ${ }^{24}$ Wenham notes that, "Famine compelled all the patriarchs to leave Canaan at different times (Gen 26:1; 47:4; cf. Ruth 1:10)." ${ }^{25}$ 
To escape the famine, Isaac and his family resided in Gerar for a long time (Gen 26:8). It appears that compared to his father Abraham or later his son Jacob, Isaac's movements were more local in character besides the relocation to this neighbouring Philistine territory. But in Gerar, Rebekah also faced the kind of threat that Sarah was subjected to in Genesis 12 and 20. She was beautiful and the men of Gerar would take an interest in her. Therefore, in this type scene, Isaac, who had learnt one or two lessons from his father about the art of lying which some call diplomacy or discretion, told the men of the city that Rebekah was his sister (Gen 26:7). Unlike the case of Sarah (Genesis 12;20), Rebekah was not actually abducted, but Isaac had anticipated the possibility that it would happen. Eventually, Abimelech one day caught him fondling his wife and accused Isaac of lying and putting the men of the city at risk, because they could easily have lain with Rebekah (Gen 26:8-10). It was now Abimelech and not the Deity who intervened and called for protection for Rebekah and Isaac. In this scene also, the voice of Rebekah is not heard; Isaac made all the decisions. From the cases of Rebekah and of Sarah, it is evident that migrating or migrant women faced threats of what we today would recognise as sexual harassment, as well as sexual assault. Their vulnerability was compounded by the fact that they were women and strangers at the same time.

Subsequently, when Isaac became too powerful in Gerar, the people demanded out of envy that he move his family elsewhere. He, therefore, removed his household to the valley of Gerar (Gen 26:14-17). But there were perennial clashes with the local herdsmen over the wells of water and the family had to be on the move constantly, in search of a place to settle. At that time, Jacob and Esau were already born and were probably young men already, so the strain of moving constantly would not have affected them as severely as it would children. The family moved from Gerar to the valley of Gerar, and to Beersheba (Gen 26:17-23, 32-33). Later, in his twilight years, Isaac must have moved back at some point to his father's home in Mamre where he eventually died and was buried (Gen 32:2). ${ }^{26}$

\section{Rachel and Leah and Jacob - Gen 28-35}

After the incident in which Jacob usurped the blessing of his brother Esau, he was forced to leave his parents' home in Beersheba and relocate eastward to his uncle Laban's place in Paddan Aram (Gen 28:2, 5-7) due to the hatred and threat by his brother Esau. There he sojourned for twenty years, married Laban's two daughters, had children, and acquired much goods and livestock (Genesis 29-31). He was a lone bachelor when he migrated eastward and was aware of the dangers that lurked ahead of him when he asked God to protect him on the way (Gen 28:20-22). But on his retro-migration twenty years later, he had had two wives and more than a dozen children. Jacob declared: "with my staff I crossed this Jordan, and now I have become two companies" (Gen 32:10). It is notable that in both of Jacob's migrations to and from Paddan Aram, the main cause was family dispute. 
He escaped from Esau for security reasons and escaped from Paddan Aram, because he also sought independence from Laban, his uncle and father-in-law. At this point, he was not pushed by famine like his father and grandfather were.

The first threat that the family encountered was the pursuit by Laban who actually had in mind to harm them. Jacob was able to reconcile with Laban and the family continued its journey. With Laban's issue behind them, they were confronted by the prospect of meeting Esau who had waited twenty years to settle scores with his brother Jacob. Jacob prayed earnestly for the Lord to deliver him from the hand of Esau (Gen 32:9-12), then sent gifts to appease his brother. He realised the real danger that loomed ahead of his family, and devised a plan to send the herd first and his family next, arranging the mothers and their children according to his preference with Rachel and her children at the back. There was no doubt that his wives and children were in grave danger of being harmed or destroyed by Esau's troop.

However, another hazard that women and children faced when migrating in the ancient world had to do with the strain of the journey itself as shown in Jacob's statement to Esau when the latter invited him to come along to Mt Seir:

But Jacob said to him, 'My lord knows that the children are young, and that I have to look after the sheep and cattle that are nursing their young. If they are driven too hard for even a single day, all the animals will die.'

(Gen 33:13)

We can infer that the movements were often in difficult terrains and in harsh climatic conditions that took a toll, particularly on children and their mothers who were at the risk of dying in the desert. Therefore, Jacob told Esau, "Let my lord go on ahead of his servant. I will travel more slowly, at the pace of the herds and the children, until I come to my lord at Seir" (Gen 33:14). Of course, he had no intention of going to Seir; it was one of those classic Jacob lies.

From the ford of Jabokk where he had that encounter with Esau, Jacob moved his family to Succoth where they settled temporarily before finally heading for Shechem (Gen 33:17-20). In Shechem, the family actually settled down as Jacob acquired land. But a grievous incident occurred in Shechem that points to the kind of peril that young girls face, especially in foreign territory. Dinah, the daughter of Leah and Jacob, was raped by the son of the ruler of Shechem. It was a horrendous incident that threatened to split the family after Simeon and Levi took revenge on the men of Shechem (Genesis 34). Not only does the narrative show Dinah in a vulnerable position in a foreign environment that was completely different from the secure environment where she grew up at her grandfather's place in Paddan Aram. There is also an interesting twist to the story as the foreigners - Jacob and his family - who were prone to xenophobic attacks and treatment had turned into the aggressor. Xenophobic attacks on immigrants and foreign settlers were not uncommon and, although 
travellers in the ancient world generally encountered dangers and hostility from some communities when in transit as the stories of Lot's guests (Genesis 19) and the man of Ephraim and his concubine in Judges 19 illustrate, the point is that women were especially more susceptible to such dangers. That the patriarchs' wives experienced the threat of or abduction by powerful men underscores not only their powerlessness, but the shaky nature of the security that their own husbands offered.

The Shechem incident, however, demonstrates that migrants are in certain instances the aggressor, and when this happens, it is the women and the children who still receive the short end of the stick. When the sons of Jacob decided to attack the men of Shechem for the dishonour brought on their sister and the family, "They captured as plunder all their wealth, all their little ones, and their wives, including everything in the houses" (Gen 34:29). The children and the women of Shechem were at the receiving end. Indeed, men are also in danger, but when two elephants fight, we know that it is grass that suffers. The fact that Jacob's sons were the aggressors remind us that migrants themselves sometimes engage in criminal and shameful acts in foreign land. For example, in a later episode in Genesis 38, we read that Judah married a Canaanite, which he probably would not have done if he was in their country of origin. Then he went in to a woman who he presumed was a harlot and handed her the emblems of his power and masculinity. Among his brethren, Judah would have found it difficult to patronise a harlot, but when in a foreign land, often anything goes. An African (Yorùbá) adage says, "Orúkọ tó bá wu ni là njẹ lẹhin odi" (literally, you can choose whatever name you wish to be called when in a foreign land). In other words, because they are far from their homeland, foreigners can put on a mask and engage in things that they would not naturally do in their homeland because of family honour and reputation. Such behaviours, as can be expected, could have negative outcomes for their families, as the incident in Shechem and the Judah example show.

Subsequent to the massacre of the men of Shechem, Jacob and his family again took to flight. Jacob complained that his sons had made the whole family vulnerable to attack by the people of the land (Gen 34:30-31). The reason for the migration was politically motivated and bothered on safety. In Gen 35:1-2, the Lord therefore instructed Jacob to move his family to Bethel. Only Jacob heard from the Lord. He simply relayed the instruction to his wives and children. But we see that the journey was fraught with danger, as the one who could have been the oldest member of Jacob's caravan - Deborah Rebekah's nurse - died on the way (Gen 34:8). Shortly after, another vulnerable member of the group, the heavily pregnant Rachel went into labour, and also died on the way. Although Jacob followed the divine command to move his family from Shechem, putting his family - especially the aged Deborah and his pregnant wife - at risk was inexcusable. The same Jacob had earlier expressed concern for the women and children in his encounter with his brother Esau. 
But this time, he was not mindful of their health and other personal needs. The movement was accomplished at great cost to the whole family.

Jacob and his family arrived in Bethel (Gen 35:6) and pitched their tents on the way (near Migdal) before arriving finally in Mamre in time to meet Isaac before his death (Gen 35:21,27). From that point, Jacob and his family remained in Canaan (Gen 37:1) until a famine again erupted in the land. Joseph had been forced into exile by his brothers who sold him into slavery. Like his father Jacob, Joseph also migrated - forcefully though into Egypt as a bachelor and a young man. After his brothers came from Canaan to buy grain in Egypt, they returned with the entire household and their father Jacob to settle in the land. What was to be a visit turned out to be permanent residence. The interjecting story of Judah shows that migrants are often exploited by locals. However, Wenham points out that "The danger of immigrants being exploited is frequently harped on in the law, e.g. Exodus 22:20 (21); 23:19." ${ }^{27}$ It is interesting though that the law does not warn people to guard against being exploited by immigrants. The migration of Jacob and his family to Egypt serves as the final migration episode in Genesis 12-50. The family moved from Beersheba at the instruction of the Lord and went down into Egypt as a people. By this time, Jacob was already an old man, and the concern for his health and that of the wives and children was demonstrated by the gesture of putting them in the wagon that Jacob sent to transport them into Egypt (Gen 46:5). They settled in Goshen in Egypt and flourished in the land.

\section{Concluding Reflections on Genesis $12-50$ and the Effects of Migration on Women and Children}

Above, I have presented a reading of the various reports of migration in Genesis 12-50 and the effects of such movements on the women and children in the migrating groups, not only in the course of the journey but at the stage of settlement. It is shown that the push factors in such migrations included famine, family crisis, political disputes with the inhabitants of the land, and divine instruction, among other things. Besides the common hazards that migrants faced, including exploitation by the locals and attacks on the way, we see that women and children were particularly prone to sexual exploitation and assault, health hazards and death.

Glimpses into the migration experiences of the matriarchs and their families in Genesis 12-50 throw some light on the contemporary immigrant crisis and on the plight of migrant women and children today. Hundreds of thousands of migrants attempt to enter Western Europe and North America from Syria, different parts of Africa, from eastern Europe, Latin America, and other parts of the developing world. The push factors vary from economic, political, religious to ecological, while they are drawn to the receiving nations because of the prospect of employment, security, and so forth. News reports show that 
daily many migrants die at sea trying to get into Europe through Spain or Italy and while crossing the desert to get into Europe from North Africa. Many of these refugees, asylum seekers and so-called illegal immigrants are women and children, who sometimes encounter untold hardships not only in the course of moving from one country to another, but also in their effort to settle down in foreign spaces, particularly in refugee camps. The strain of the journeys in modern movements is also comparable to the hazards that are noticeable in the ancient migrations. Many die on the way, like Deborah and Rebekah; many are sexually harassed, exploited and assaulted like Sarah, Rebekah and Dinah; while many are displaced, hungry and thirsty and deprived like Hagar and Ishmael.

Indeed, the reality that many women today migrate successfully independent of men or other family members could imply that the talk of women's vulnerability is a mere myth. However, the real incidents of death, sexual violations and various other challenges that seem to be peculiar to women and children show that such vulnerability should be taken seriously when making or revising immigration policies and decisions that affect women and children.

It is also important to scrutinise the emotional impact of long-distance migration on women and children more closely, not only in the Hebrew Bible but also in contemporary migration studies. It is conceivable that the many women in Genesis 12-50 as well as in the Hebrew Bible as a whole who experienced forced or voluntary migration must have gone through great emotional traumas and upheavals due to displacement and the long distance from the place they used to call home. One could think of Rebekah and her nurse Deborah, Leah, Rachel and Dinah, Hagar and Ishmael, Lot's two daughters, Ruth and Naomi, as well as the countless nameless women who moved out of Egypt in the exodus migration and in the exile to Assyria and to Babylon, among others. Today, many women and children are being uprooted from war-torn territories and from countries with severe ecological and economic problems with not much thought for their emotional well-being. As in the case of Abraham and Sarah or Isaac and Rebekah, the lack of consideration for the feelings, personal dignity and honour of these women on the part of their men in some instances remains worrisome. Many such women and children are also visible in teaching and learning contexts where they continue to struggle with the effects of the health and safety hazards they encountered in the course of migration and settling down. Rereading biblical stories on migration and women could help them to find resonance with the experiences of their ancient counterparts whilst helping others also to connect with them at a deeper and empathic level of dialogue.

Migration has become a global phenomenon and the attendant problems have also become a global crisis as the ongoing situations in Europe and America confirm. Borders of nations are no longer as porous as in the ancient world, making migration more hazardous as people from less endowed nations take some desperate risks to cross these borders. 
The insight from the biblical narratives above confirms that the hazards that migrant women and children encounter do require more urgent intervention. The silence of the women and children in decisions to migrate, which ultimately affect their overall well-being, prosperity and safety, also needs to be addressed in more practical ways.

\section{Bibliography}

Ahn, John J. Exile as Forced Migrations: A Sociological, Literary, and Theological Approach on the Displacement and Resettlement of the Southern Kingdom of Judah. BZAW 147. Berlin/New York: Walter De Gruyter, 2011.

Ahn, John and Ames, Frank Ritchel. "Introduction." Pages 1-8 in The Prophets Speak on Forced Migration. Edited by Mark J. Boda, Frank Ritchel Ames, John Ahn, and Mark Leuchter. Atlanta, GA: SBL Press, 2015. https://doi.org/10.2307/i.ctt1b7×6cn.5

Ames, Frank Ritchel. "Forced Migration and the Visions of Zechariah 1-8." Pages 147-159 in The Prophets Speak on Forced Migration. Edited by Mark J. Boda, Frank Ritchel Ames, John Ahn and Mark Leuchter. Atlanta, GA: SBL Press, 2015. https://doi.org/10.2307/i.ctt1b7x6cn.15

Arnold, Bill T. Genesis. NCBC. New York: CUP, 2009.

Boyle, Paul; Halfacree, Keith and Smith, Darren. "Family Migration and Female Participation in the Labour Market: Moving Beyond Individual-level Analyses." Pages 114-135 in Migration and Gender in the Developed World. Edited by Paul Boyle and Keith Halfacree. Routledge Research in Population and Migration. London: Routledge, 1999.

Castles, Stephen and Miller, Mark J. The Age of Migration: International Population Movements in the Modern World. Fourth Edition. New York: The Guilford Press, [1993] 2009.

Dobrowolsky, Alexandra and Tastsoglou, Evangelia. "Crossing Boundaries and Making Connections." Pages 1-35 in Women, Migration and Citizenship: Making Local, National and Transnational Connections. Edited by Evangelia Tastsoglou and Alexandra Dobrowolsky. Gender in a Global/Local World Series. Hampshire, England: Ashgate, 2006.

Hashim, Iman and Thorsen, Dorte. Child Migration in Africa. London: Zed Books, 2011.

Lim, Bo. "Exile and Migration: Toward a Biblical Theology of Immigration and Displacement." The Covenant Quarterly 74/2 (May 2016): 3-15.

Papstergiadis, Nikos. The Turbulence of Migration: Globalization, Deterritorialization and Hybridity. Cambridge, UK: Polity Press, 2000.

Parpart, Jane; Marchand, Marianne and Barber, Pauline Gardiner. "Preface". Pages xi-xii in Women, Migration and Citizenship: Making Local, National and Transnational Connections. Edited by Evangelia Tastsoglou and Alexandra Dobrowolsky. Gender in a Global/Local World Series. Hampshire, England: Ashgate, 2006.

Petersen, David L. "Prophetic Rhetoric and Exile." Pages 9-18 in The Prophets Speak on Forced Migration. Edited by Mark J. Boda, Frank Ritchel Ames, John Ahn and Mark Leuchter. Atlanta, GA: SBL Press, 2015 https://doi.org/10.2307/i.ctt1b7×6cn.6

Reuter, Astrid. "Migration." Page 344 in Religion, Past and Present: The Encyclopedia of Theology and Religion. Edited by Hans Dieter Betz, Don S. Browning, Bernd Janowski, Eberhard Jüngel. Leiden: Brill, 2010.

Sarna, Nahum M. Genesis תישאר . The JPS Torah Commentary. Philadelphia, PA: JPS, 1989.

Thorsten, Prill. Global Mission on Our Doorstep: Forced Migration and the Future of the Church. Münster: MV Wissenchaft, 2008.

United Nations. "The International Migration of Women: An Overview." Pages 1 -10 in International Migration Policies and the Status of Female Migrants. Proceedings of the United Nations Expert Group Meeting on International Migration Policies and the Status of Female Migrants, San Miniato, Italy, 28-31 March 1990. Department for Economic and Social Information and Policy Analysis Population Division. New York: United Nations, 1995.

Wenham, Gordon J. Genesis 1-15. WBC 1. Waco: Word Books, 1987.

Westermann, Claus. Genesis: A Practical Commentary. Text and Interpretation, transl. David E. Green. Grand Rapids, MI: Eerdmans, 1987. 


\section{Endnotes}

1 Claus Westermann, Genesis: A Practical Commentary (Text and Interpretation; transl. David E. Green; Grand Rapids, MI: Eerdmans, 1987), 88. Note also Bo Lim's reflection on the fact "that God's people have always been an immigrant people, negotiating their identity and vocation in new cultural contexts." Bo Lim, "Exile and Migration: Toward a Biblical Theology of Immigration and Displacement," The Covenant Quarterly 74/2 (May 2016): 3-15 (10).

2 Westermann, Genesis, 98.

3 Nahum M. Sarna, Genesis תישארב (The JPS Torah Commentary; Philadelphia, PA: JPS, 1989), 80.

4 Nikos Papstergiadis, The Turbulence of Migration: Globalization, Deterritorialization and Hybridity (Cambridge, UK: Polity Press, 2000), 9. A. Dobrowolsky and E. Tastsoglou, "Crossing Boundaries and Making Connections" in Women, Migration and Citizenship: Making Local, National and Transnational Connections, ed. Evangelia Tastsoglou and Alexandra Dobrowolsky (Gender in a Global/Local World Series; Hampshire, England: Ashgate, 2006), 16. Stephen Castles and Mark J. Miller, The Age of Migration: International Population Movements in the Modern World (Fourth Edition; New York: The Guilford Press, 2009), 3.

5 See Prill Thorsten, Global Mission on Our Doorstep: Forced Migration and the Future of the Church (Münster: MV Wissenchaft, 2008), 25. Lim affirms that, "Voluntary migration is often labor migration by which people seek better economic conditions. Forced migration, by contrast, is the result of war or enslavement." Lim, "Exile and Migration," 7. Defining forced migration in the context of the visions of Zechariah, Ames notes that, "Forced migration, the relocation of members of a community due to armed conflict, infrastructure project, or natural disaster, is a persistent social phenomenon." Frank Ritchel Ames, "Forced Migration and the Visions of Zechariah 1-8" in The Prophets Speak on Forced Migration, ed. Mark J. Boda, Frank Ritchel Ames, John Ahn and Mark Leuchter (Atlanta, GA: SBL Press, 2015), 147. Whereas Petersen also recognises voluntary and forced migrations, he mentions a third category - incarceration - in which prisoners are taken and moved away from their land. Petersen, David L. "Prophetic Rhetoric and Exile" in The Prophets Speak on Forced Migration, ed. Mark J. Boda, Frank Ritchel Ames, John Ahn and Mark Leuchter (Atlanta, GA: SBL Press, 2015), 9-10.

6 Astrid Reuter, "Migration" in Religion, Past and Present: The Encyclopedia of Theology and Religion, ed. Hans Dieter Betz, Don S. Browning, Bernd Janowski and Eberhard Jüngel (Leiden: Brill, 2010), 344.

7 Thorsten, Global Mission, 27; Reuter, "Migration," 344.

8 Cf. Papstergiadis, The Turbulence of Migration, 2; Castles and Miller, The Age of Migration, 10-12.

9 Dobrowolsky and Tastsoglou, "Crossing Boundaries," 17.

10 Thorsten, Global Mission, 30.

11 Castles and Miller, The Age of Migration, 47.

12 Iman Hashim and Dorte Thorsen, Child Migration in Africa (London: Zed Books, 2011), 13.

13 Dobrowolsky and Tastsoglou, "Crossing Boundaries," xi, 25.

14 Ibid, 19; Castles and Miller, The Age of Migration, 12. Jane Parpart, Marianne Marchand and Pauline Gardiner Barber, "Preface" in Women, Migration and Citizenship: Making Local, National and Transnational Connections, ed. Evangelia Tastsoglou and Alexandra Dobrowolsky (Gender in a Global/ Local World Series; Hampshire, England: Ashgate, 2006), ix.

15 United Nations, "The International Migration of Women: An Overview," in International Migration Policies and the Status of Female Migrants. Proceedings of the United Nations Expert Group Meeting on International Migration Policies and the Status of Female Migrants, San Miniato, Italy, 28-31 March 1990 (Department for Economic and Social Information and Policy Analysis Population Division; New York: United Nations, 1995), 9.

16 Ibid.

17 Paul Boyle, Keith Halfacree, and Darren Smith, "Family Migration and Female Participation in the Labour Market: Moving Beyond Individual-level Analyses" in Migration and Gender in the Developed World, ed. Paul Boyle and Keith Halfacree (Routledge Research in Population and Migration; London: Routledge, 1999), 114. It is reported also that "Women and children are especially vulnerable, and they make up 80 percent of displaced persons in times of war." Lim, "Exile and Migration," 13.

18 Hashim and Dorte Thorsen, Child Migration in Africa, 13.

19 Westermann, Genesis, 97.

20 Sarna, Genesis, 94. 
21 Anyone who watches the programme Border Security on Cable TV would attest that many people who cross national borders tell a lot of lies.

22 Westermann, Genesis, 103.

23 Gordon J. Wenham, Genesis 1-15 (WBC 1; Waco: Word Books, 1987), 285.

24 Bill T. Arnold, Genesis (NCBC; New York: CUP, 2009), 129.

25 Wenham, Genesis 1-15, 287.

26 "So Jacob came back to his father Isaac in Mamre, to Kiriath Arba (that is, Hebron), where Abraham and Isaac had stayed" (Gen 35:27).

27 Wenham, Genesis 1-15, 287. 



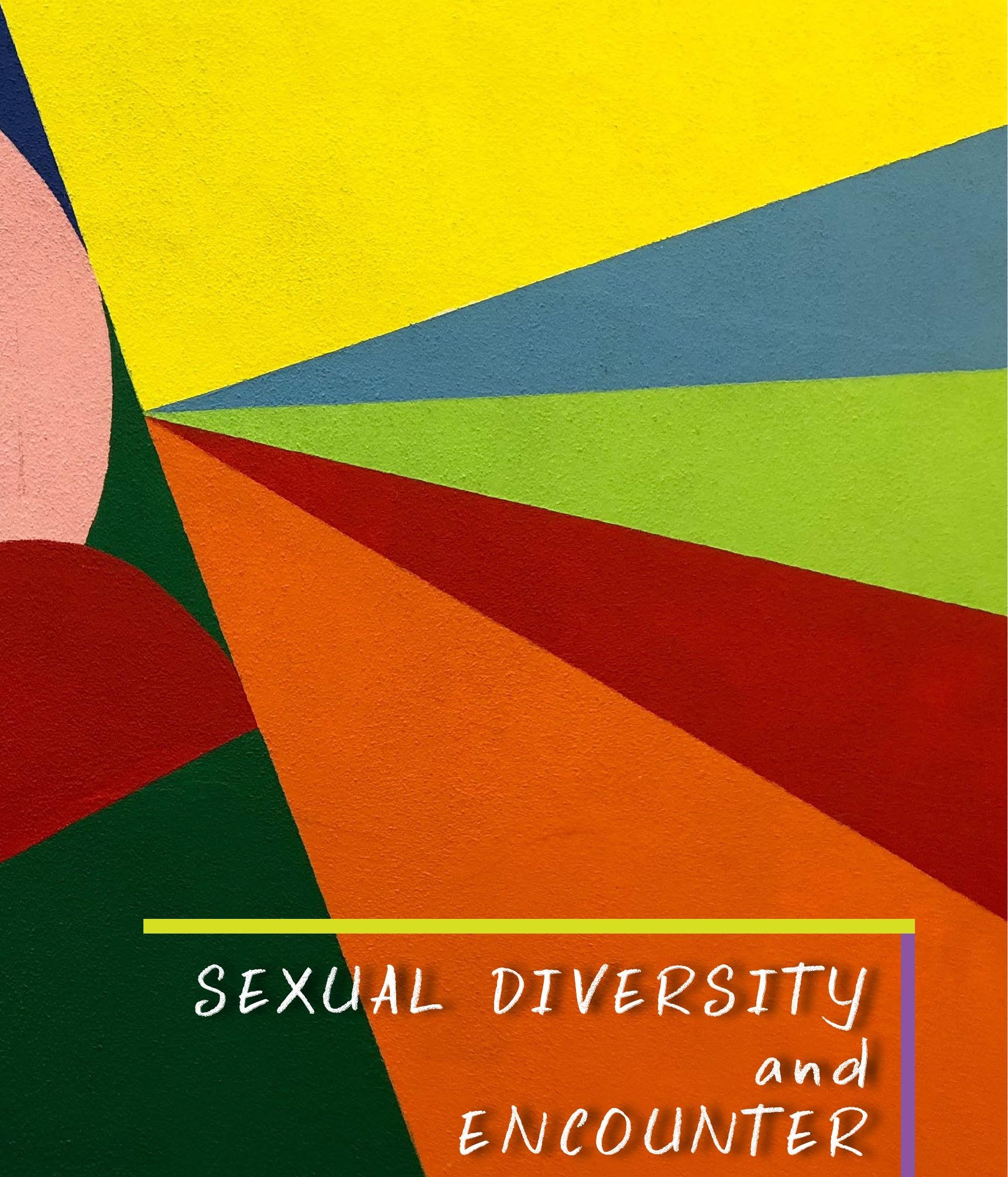




\section{DEPLOYING INDECENT LITERARY AND SOCIO-HISTORICAL DETAIL FOR CHANGE}

\section{Genesis 2:18-24 as a Resource for Choice of Sexual Partner}

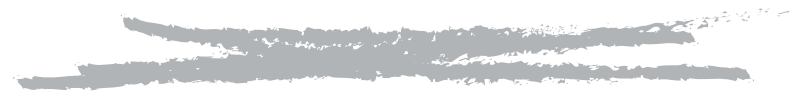

Gerald 0. West

School of Religion, Philosophy and Classics

8 Ujamaa Centre

University of KwaZulu-Natal

\section{Introduction}

In his book A Question of Truth: Christianity and Homosexuality, Gareth Moore deals not only with what he calls "The Bible against homosexuality?" but also "The Bible for heterosexuality?" The question marks in each case are instructive for Moore interrogates both the well-worn allegedly "anti-homosexual" biblical texts and the reasonably familiar allegedly "pro-heterosexual" biblical texts. In dealing with Genesis 2, the focus of my essay, Moore counters the "standard view" by pointing out his difficulties with this view. ${ }^{1}$ As in most of his analysis of biblical texts associated with discussions on homosexuality, Moore begins by offering some "literary" analysis (though not in a systematic analytical manner), attempting to give the text as text a presence. However, his primary method for destabilising the "standard view" is to situate a biblical text within its socio-historical context of production. Here again he does not do this in the detailed systematic analytical manner that biblical scholars are familiar with. What he offers is a general socio-historical context focusing specifically on "the sexually hierarchical nature of Israelite society". ${ }^{2}$ His primary point is stated as follows: "Yet these obvious features [of the socio-historical setting] of the text [Genesis 2] are often overlooked by Christian writers in an attempt to ground here [in Genesis 2] a Christian view of marriage."

Moore's emphasis is theological and therefore he is overt about engaging with "a Christian view of marriage". He is wise to include the indefinite article for he goes on to argue that though "equality of man and woman is part of modern Christian doctrine, and happily so", 
"the text of Genesis 2 does not express modern Christian doctrine; it expresses a view which is, in this respect, antithetical to modern Christian doctrine. It thus," he concludes, "hardly recommends itself as a text on which to base Christian teaching on the nature of marriage, on the relationship between the sexes and on sexual relationships." ${ }^{4}$ Moore's argument is clear, but many African (post?-)modern Christians would disagree, arguing that the hierarchical orientation of Genesis 2 is a vital component of "modern" African Christian marriage. ${ }^{5}$

Fortunately for us and particularly for my essay, Moore does not stop here. Immediately as he begins a new section within the sub-heading "An alternative view," he goes on to say: Nevertheless, one cannot abandon a text of Scripture because it has its origin in and reflects values which are very different from our own. The reason why we call Scripture the word of God is because we believe that we have something to learn through it, that God has something to teach us through it. Texts of Scripture, even difficult ones, are precious gifts which must not be thrown away. ${ }^{6}$

While I would not use Moore's language, I share his commitments. As an African biblical scholar, I dare not abandon the Bible. Letting go of it means letting the dominant and dominating theologies have it to themselves. In my work and the community-based work of the Ujamaa Centre for Community Development and Research, the Bible is a site of struggle both inherently and in terms of its interpretations. We contend for "a/the word" that brings life rather than death. ${ }^{7}$ And this is precisely what Moore attempts to do - reading against the hetero-patriarchal grain of Genesis 2.

In this essay, I will follow Moore but deepen his analysis of both the literary and sociohistorical detail of Genesis 2. I will then use this (indecent) detail to construct a Contextual Bible Study resource for the work of the Ujamaa Centre.

\section{An Indecent Question}

"What, then," asks Moore, "can we legitimately get out of the plain meaning of this text" for the purposes of an "appropriate Christian attitude towards homosexual relationships"?8 While I am wary of claims to "the plain meaning" of a text, what Moore means by this is a fairly careful analysis of the text as narrative. Moore is not a biblical scholar and is unaware, for example, of the pioneering narrative work of Phyllis Trible on Genesis 2 and the array of biblical scholarship that has clustered around Trible's readings. ${ }^{9}$ However, he is a reasonably careful follower of the narrative (in English translation).

Moore begins by going back "to the situation which leads to the creation of Eve". ${ }^{10}$ God's acknowledgement that "Adam" is alone and that this is "not good" draws a "reaction" from God "resolving to create a help for him". "From the story so far," Moore argues, "given 
that Adam had been put in the garden to tend it, we might imagine that what God wants to create is a help who is fit also to tend the garden." "But no," continues Moore, God "wants to create a help fit for the man, a partner, as we might say." ${ }^{12}$ In Moore's reading of the narrative, the emphasis is on a partner who is "a help in a deeper sense than a mere assistant, one to lighten the workload," for as Moore notes, "by the end of the story, it will have become clear that the help is to be a life-partner, and a sexual partner."13

With this end in view, Moore then pays particular attention to how the narrative develops. The transition from verse 18 to 19 is somewhat odd given the "end of the story". For, as Moore recognises,

It is in an attempt to make this help that God sets about creating the animals. It is they whom he makes first as project partners for the man, not the woman; the woman is created only when all the animals have been tried and have failed. ${ }^{14}$

What we have here, Moore argues, is "the picture of God improvising: he tries one thing, then another, the camel then the snake, trying to find the appropriate partner for the man; but he does not succeed. ${ }^{15}$ Moore then asks a key question:

This raises the question: what counts as success, and what is the sign of success ... Why does not God effectively say to him: 'Here is the help I have made for you; now get on with it'? God has after all in one sense succeeded: he has made what he wanted to make ... and he has made it for the purpose of being a help to the man, in the sense of a companion, because it is not good for him to be alone. ${ }^{16}$

The discourse modality of Genesis 2 is quite different, Moore notes, from Genesis 1: "If we were still in chapter 1 , there would be no question of divine failure. God would simply have said, 'Let it be so', and it would have been so." ${ }^{17}$ Here, in Genesis 2, "the atmosphere is very different. Here God can fail and does." ${ }^{18}$ That God does not insist on any of the animals as an appropriate partner for "the man" leads Moore to two conclusions in terms of the final form of the narrative that we have: "First, in making the animals one after the other and bringing them to Adam, God is imposing nothing on Adam. Rather, he is trying them out, suggesting. If one thing doesn't work, he is willing to try another." Secondly and more importantly, "we get the distinct impression that the criterion of its working is Adam's reaction to the animal God presents him with. Success does not depend on God's reaction." This is Moore's major argument namely:

When God brings the newly created animals to Adam to see what he will call them [and in the process discern whether any of them are an appropriate fit], he [God] submits them for his ['Adam's'] judgement. It is because Adam does not react to each one positively as a prospective life partner that God goes off and makes the next one. ${ }^{19}$

As Moore goes on to admit, "This point is for the moment only an impression," but, "it is strikingly confirmed in what follows, when God makes Eve for Adam." "This time," Moore continues, "God is successful. But he [God] is not the judge of his success; Adam is." 
As before with the animals, God grants "Adam" the right to form a judgement about the appropriateness of what God has made:

It is quite explicitly Adam's reaction that signals the success of the attempt. It is because he reacts positively to Eve, because he receives her with joy, that we know the quest for a partner has reached a successful conclusion. ${ }^{21}$

Biblical scholars will find Moore's acceptance of the language of typical English translations problematic, but I have retained Moore's formulations precisely because they demonstrate that even if we work with the lack of precision of this kind of English translation, we are still confronted with the clarity of the narrative logic Moore identifies. As Moore goes on to argue, following the narrative logic to its end, "it is at this point that God ceases looking for a partner for Adam. He [God] quite simply accepts Adam's judgement, never even expressing his own." 22 Pushing on to his own appropriation of this narrative logic, Moore argues:

Or perhaps as far as God is concerned it is not up to him [God] to judge in this area of human life. The fitting partner for the man, then, is the one that he, the man, receives with joy, the one whom he himself recognises as a partner fit for him. ${ }^{23}$

"In this story," Moore concludes,

God imposes nothing; he is the servant of the man's need, and submits his attempts to the man's judgement. He recognizes that it is not good that the man live in solitude, and that this solitude can be alleviated only by a 'help' that gladdens the man's heart, by one he actually wants. Any partner whom God imposed regardless of the man's reaction or, worse, despite the man's negative reaction, would thereby fail to be the kind of partner the man needs. ${ }^{24}$

Following the narrative shape into his contemporary context, Moore claims,

That it is Adam himself who decides on the companion he will have should be no surprise, for that is just the sort of thing a companion is. A companion, in the sense of companionship which is in view in this text, is somebody you actually want to be with and to share your life with. An imposed companion would be no companion at all. ${ }^{25}$

For Moore, this is the significance of the shape that the narrative as we have it holds. The narrative reveals something about human companionship and about God:

That is why God can only propose, suggest, and wait upon the man's reaction, for it is only in this way that God can succeed in doing what he [God] wants: to give Adam a companion that Adam wants to be with. If he [God] imposed his own will by imposing a partner of his [God's] choice rather than Adam's choice, God would frustrate his own project. In creating Adam as one for whom it is not good to be alone, God creates him as one whose heart needs to be gladdened by another, one who needs to delight in another, and he puts himself at the service of that need, seeking again and again one who will indeed make glad his heart, for it is thus and only thus that God fulfills his own project too. ${ }^{26}$

"All depends on Adam's reaction." ${ }^{27}$ This, argues Moore, is what the narrative signifies for this is "the way the story is told" ${ }^{28}$ And Moore then follows the narrative shape, not only for "Adam" but also for "us" - all of us. Moore argues: 
If we abstract from the unchristian sexism which is also expressed in this story, and which makes the woman find her reason for existing only in satisfying the man's need, then Adam becomes the representative human being, and we can say that God is at the service of our delight, of the delight of all of us, men and women ... [gay and straight]. ${ }^{29}$

Moore accepts that the narrative follows hetero-patriarchal norms in that Adam "ends up with a woman as his partner" but not, he insists,

because God imposes a woman on him. Adam has a woman, not because that is how God wants it, but because that is how Adam wants it, and God is at the service of Adam's delight. Adam is delighted by Eve, a woman. That is apparently how most men are; it is with a woman that they enjoy or wish to enjoy an intimate partnership. And most women apparently enjoy or seek to enjoy an intimate partnership with a man. But there are exceptions. Apart from those who do not enjoy or particularly seek an intimate partnership with anybody, there are men who delight in another man, and there are women whose heart is gladdened by another woman. Because God is at the service of the delight of Adam, the representative human being, we must suppose that he is also at the service of the delight of men whose heart is gladdened by a man and of women who delight in a woman. Just as God is shown here taking seriously the need of Adam for a fit partner, a partner whom he will receive with joy, so, we must suppose, he takes seriously the need of lesbians and gay men for a partner whom they will receive with joy. ${ }^{30}$

Moore then makes a bold theological move, recognising that some might foreground the narrative outcome rather than the narrative shape. "Adam does after all," Moore acknowledges, "welcome a woman as his partner, not a man. Is this not a model for us? Are we not presented here with a [heterosexual] model of humanity such as God wills it, and are we not therefore obliged to follow it?"31 Instead of arguing - as I will do more fully later that narrative shape is itself a distinctive contribution of this particular text, Moore shifts to the theological terrain. "No," he insists, we do not need to follow this particular outcome:

We are not disciples of Adam, but of the second Adam, Jesus Christ. What is essential for us here is not the will of Adam but the will of God. And the will of God shows itself here as the will to serve, just as Jesus Christ came to serve. Here he [God] is shown serving the needs of those he has created needing to delight in and to enjoy intimate companionship with another. Adam is left free to accept or refuse, and his acceptance follows not from obligation but from delight. We respect the role of God in this story if we say that, like Adam, we too are left free, that we too are to accept the partner in whom we delight. ${ }^{32}$

While I admire Moore's "doing of theology" here, I want to remain with the detail of Genesis 2. Moore has identified the narrative shape of Genesis 2 which I will elaborate in the next section. But before doing this, it is worth noting Moore's engagement with the sociohistorical detail of Genesis 2. In addressing the question "Why a woman?" Moore reflects on how we might 'appreciate' "the fact that God does after all create for Adam a woman as his partner, and that Adam accepts her" without having "to resort to making a heterosexist theology of sexuality". ${ }^{33}$ Moore turns his attention to the ancient world that produced the text, introducing what he considers to be distinctive features of that world. First, "Adam, as 
the representative man, is also the typical man. Typically, men do want a woman for their partner, not another man", which "was as true in the ancient Israel that gave birth to this story as it is in most places today. It is therefore quite natural that the story should be told in those terms." ${ }^{34}$ However, Moore does not leave it there, insisting, "But a story framed in terms of the typical does not of course morally exclude the atypical." 35 Second, the story "is also supposed to be the story of the first man, the founder of the human race, from whom we are all descended" and of the "first couple". ${ }^{36}$ It follows therefore that the "aetiological aspect of the story" requires, says Moore, "a mixed-sex couple, for, as a matter of fact, that is how the human race propagates." ${ }^{37}$ Third, argues Moore, "the status of Adam as the representative man - the man - excludes a second representative man and also calls for somebody to fulfil the role of the woman" ${ }^{38}$ given the ancient Near Eastern context. Fourth, "if this story is of the beginning of the human race, it is also of the origin of marriage, the institution which binds a man and woman together. This is made clear," says Moore, again echoing most English translations "by the narrator in verse 24. For it to be this, it must be the story of a man and a woman; Adam must delight in a woman." ${ }^{39}$ And fifth, as it is true "that ancient Israelite society was patriarchal and sexist, and undervalued women", so also it is true that "it was also a society which disapproved in the strongest possible way of sexual relations between men".

Moore nuances his fifth claim elsewhere in his book by explaining more fully what precisely was being disapproved of in sexual relations between men; ${ }^{41}$ but this is not why I have summarised his socio-historical account of Genesis 2. My interest is in the indecent detail he does not detect in his fourth claim. Genesis 2:24 is not primarily about marriage - it is about sex, indecent sex.

\section{An Indecent Narrative Shape}

We will return to this indecent socio-historical detail, but before we do, I will provide a more detailed account of the indecent narrative shape of Genesis 2 in its final form as we have it. I say "as we have it" because I am not now making claims about the text's production (which will come later), only about the shape of the text in its final form. This is the text that our churches have before them. As I said earlier, part of my reason for using Moore's work is that he works with this final form in contemporary English translation. There is nothing, in other words, in Moore's interpretation of the narrative shape that is beyond an ordinary reader of Genesis 2. Why then has the (indecent) narrative shape of Genesis 2 not been noted more regularly?

My use of the adjective "indecent" follows the work of Marcella Althaus-Reid, signalling both the recognition of a particularly neglected theological domain (sexuality) and a way of doing theology (method). For Althaus-Reid, being indecent is an interpretive attitude, for 
indecent theology 'questions' "the traditional ... field of decency and order as it permeates and supports the multiple ... structures of life..." ${ }^{42}$ The various forms of liberation theology demonstrate, she argues,

that in theology it is not stability but a sense of discontinuity which is most valuable. The continuousness of the hermeneutical circle of suspicion and the permanent questioning of the explanatory narratives of reality implies, precisely, a process of theological discontinuity. ${ }^{43}$

"As part of this process," she continues, pushing liberation theology beyond its decent boundaries,

the location of areas of exclusion in theology is one of crucial importance; for instance, poverty and sensuality as a whole (and not as separate units) has been marginalised in theology. A theology from the poor needs also to be a sexual theology, a theology of economics and desires that have been excluded from our way of 'doing theology' as a second act. ${ }^{44}$

Like Moore, Althaus-Reid is interested in the atypical person, the "unusual" person. Her focus is on poor urban Christian women. "Not only does their economic struggle test them every day but there is a mixture of poverty and sexuality which makes of these women sometimes unusual poor women, and unusual Christian believers too." This "unusualness", she argues, "is the condition of their indecency, that is, of the subversion of sexual and gender codes in their lives as a result of their struggle for life and dignity." ${ }^{25}$ In this sense, "the project of Indecent Theology represents both a continuation of Liberation Theology and a disruption of it." ${ }^{46}$ The disruption she calls for is radical, destabilising "the sexual foundations of economic and political theologies".77 Methodologically, indecent theology must 'disrespect' "the interpellative, normative forces of patriarchal theology" and patriarchal biblical text. ${ }^{48}$ Indecent interpretation calls for an "unmasking and unclothing" of the sexual assumptions built into both biblical text and theology, ${ }^{49}$ intersecting the sexual with liberation theology's recognition of the political and economic.

While I accept that in many cases we do require a "disrespecting", an "unmasking" and an "unclothing" in order to do an indecent interpretation, there are cases such as in Genesis 2 where there is readily apparent indecent detail that should be respected. Moore's "plain meaning" is present in the biblical text. The narrative shape of Genesis 2 is indecent perhaps even more so than Moore recognised.

The narrative shape of Genesis 2, in broad terms following Aristotle and others, ${ }^{50}$ includes an exposition in which God "made" earth and the heavens (but incompletely, as the complications that follow indicate), a series of intersecting complications, and a series of intersecting resolutions to those complications.

My focus is on a particular narrative emphasis, the complication that the creature God has made in verse 7 (as a resolution to the complication of v.5) is acknowledged by God, using direct speech, to be "alone" and that this is "not good". It is as if the resolution of the creation 
of a creature - made from the ground (v.7) to care for the ground (v.15) along with the provision of God for this creature (vv. 8-9) which would enable this creature to live a long life (vv. 9 and 16) but with the possibility of death as another complication (v.17) - prompts a complication concerning the (incomplete) identity of the creature.

So far, the narrator has told the implied reader relatively little about this character. Ha-adam is a creature made from a combination of "dust of the ground (ha-adama)" and "the breath of life". God is the subject of both verbs, making and breathing ha-adam into being as "a living nephesh" ${ }^{51}$ No more is said about the identity of this creature. What we are told next is about the tasks of this creature - "to till it and to keep it" (v.15) - here referring to the garden (vv. 8 and 15) specifically but also "to serve ha-adama" more generally (v.5). An earth creature is made by God to serve the earth and to keep and till it. The text summons an ecological reading but that is not my focus.

In the narrative form we have, including the interpolated geo-political eco-economic section from verses 10-14, there is a digressive pause between the narrator's invocation of "the tree of the knowledge of good and evil" (v.9) and God's specific prohibition against eating from this tree (v.17). This temporal pause in the narrative enhances the narrative tension implicit in this complication, signifying that it is an important complication, one the implied reader would do well to note. However, no sooner in narrative time has the implied reader begun to concentrate on this complication than another complication is introduced in verse 18.

This complication too is voiced in direct speech. The God who warns ha-adam directly in verse 17 is the God who speaks directly in verse 18. But this time God speaks directly to the implied reader. Ha-adam may eavesdrop on the direct speech but God's speaking is not addressed to ha-adam. God may be speaking to God's-self, but in narrative terms the omniscient narrator is speaking directly via God to the implied reader. We hear God speaking. The narrative signs are clear; we are being prepared for a significant development in the narrative. What prompts this (further) complication in a story of numerous complications is not clear. As I have indicated above, it may be the possibility of death (v.17). Indeed, we expect a fuller account of this ultimate complication! And the word order of verse 18 is instructive, for yet again, there is temporal tension created by the syntax, "And Yahweh God said, 'It is not good for ha-adam..." What might the implied reader expect having read verse 17? What might be "not good for ha-adam"? The implied reader might expect some anxiety on the part of the deity about ha-adam's capacity to resist the prohibition but whatever the implied reader's narrative expectations, the narrative takes a different tack.

The narrative moves from the complication of possible death in the midst of the potential for abundant life to the complication of "aloneness". Ha-adam is alone or perhaps "a part" or "apart" (bad). The creature which God has made is part ground and part breath. However, 
we understand ha-adam's aloneness, a-partness, incompleteness, God recognises it and in committing to resolve it reveals something more about ha-adam's character. The "aloneness" of ha-adam requires a resolution in which God makes "for it a companion corresponding to it" ${ }^{52}$ The narrative so far has made it clear that "the creature's relationship to the rest of creation is ambiguous: a part of and yet apart from [verse 7]; of common ground but with power over [verse 15]; joined yet separated [verses 16-17]".53 Since ha-adam is both of the earth and other to the earth, God resolves to "make a companion corresponding to it (kenegdo)" ${ }^{54}$

For Trible and many others who come to the text with a feminist ideo-theological orientation, "what the earth creature needs is a companion, one who is neither subordinate nor superior; one who alleviates isolation through identity".55 Trible's emphasis, like that of Moore, keeps a clear focus on human sexuality, but her analysis of the narrative does not exclude and perhaps even invites an eco(logical/nomic)-feminist reading with the anticipation of a companion who would be both a co-worker in tilling and keeping the ground and the garden, and a partner resolving ha-adam's sexual aloneness. Trible does not elaborate on her ecological (or economic) recognitions but I mention the potential in her analysis in order to respond to Moore's assertion that what the narrative imagines is more than "a mere assistant, one to lighten the workload". I think the narrative could bear the weight of an eco(logical/nomic)-feminist-queer reading in which different aspects of human life are intersected. Indeed, an African queer orientation requires intersectional awareness and analysis, refusing "western" individualised notions of sexual identity and recognising how sexual identity intersects with, for example, economics. As Althaus-Reid reminds us, indecency is located in intersectionality.

For now however, we will follow Moore's indecent question and Trible's narrative exegesis. Trible does not discern Moore's indecent question in the narrative contours of the text. Instead, she interprets the making of the animals as an interlude, a narrative pause that indicates "the deity's use of delay to build suspense". ${ }^{56}$ She notes in verses 19-20 that the same verb is used as in the prelude, "make" ('sh), where the verb "described God's creation of the earth and the heavens (2:4b)". She immediately goes on to argue that this repetition prepares the implied reader for a satisfactory outcome: "Since making is a familiar activity for God, this first-person pledge would seem to assure a happy ending" for ha-adam. ${ }^{57}$ "Furthermore," she continues, "since life has unfolded thus far without delay, hesitation, or experimentation, we expect Yahweh to accomplish this goal immediately." ${ }^{\prime 8}$ It is left to the narrator to report, "but as for 'adam, it did not find a companion corresponding to itself".59

Trible's translation does not evade the grammar of ha-adam as the subject of the verb, as so many English translation do, preferring to translate the sentence in the passive (as does the NRSV, "but for the man there was not found a helper as his partner"). Trible's translation 
opens the way for Moore's indecent question, but she does not follow this narrative direction despite recognising that this "oblique" report by the narrator "does not attribute the negative result directly to God" or indeed that "for the first time, Yahweh does not appear in the conclusion of a pericope". 60 The agency of ha-adam is clear in Trible's translation making it clear that ha-adam is the one who recognises that among the animals, each of whom ha-adam has named (v. 19) and therefore interacted with, there is not an appropriate (sexual) partner.

As Trible recognises,

With the sole omission of the word dust (aphar), the line that reports the creation of the animals $(2: 19)$ is identical to the line that reported the creation of the earth creature (2:7): 'and Yahweh God formed ... from the earth'. The exact parallels of subject, verb, and material in the two accounts strongly suggest that the deity is making a creature corresponding to ha-adam. ${ }^{61}$

"And yet," continues Trible, "the repetition of this identical process produces a different object: 'every beast of the field and every bird of the heavens'. Although they are not fitting companions, the earth creature and the animals unite in the grammar and vocabulary of Yahweh's creative act. In fact," Trible notes, "the verb form (yatsar) is used exclusively for these two creations, resulting in an identity unparalleled thus far in the story." ${ }^{2}$ There is no narrative reason therefore why what God has now made should not be considered by ha-adam as an option for a partner for ha-adam.

Trible goes on to argue that, "Though the presentation of the animals began by stressing their similarities to the earth creature, it ends by focusing on their differences." ${ }^{63} \mathrm{Her}$ narrative exegesis follows the text in its detailing of the differences (again offering fertile grounds for ecological readings). My focus following Moore's indecent question is on the agency of ha-adam. It is clear from the narrative that God's agency ceases after God has brought "[each] to ha-adam to see what it would call each one". 64 Trible too recognises the shift in agency here:

Marking the beginning of human activity, the phrase 'to see what it would call each one' also signals a cessation of divine activity, and in fact, Yahweh God does recede from the episode at this point. What the story says, it does. ${ }^{65}$

Indeed, as Trible goes on to note, "This divine fading is unparalleled in the preceding episodes [of the narrative], where God determined the action from beginning to end." 66 Trible reads the narrative emphasis here as indicating something about the character of God: "Accordingly, it shows this deity now not as the authoritarian controller of events but as the generous delegator of power who even forfeits the right to reverse human decisions." ${ }^{67}$ But I would argue, following Moore's indecent question, that what God delegates to ha-adam is the choice to decide whether each of the creatures God brings to ha-adam is an appropriate sexual partner. If Trible is correct to argue, and I think she is, 
that "the narrative does not suggest failure, mistake, or fault on the part of God," 68 then this episode - verses 19-20 - is about recognition and choice. Ha-adam is given the right by God to decide on what is an appropriate companion and sexual partner.

In recognising the narrative shift towards the agency of ha-adam, Trible identifies the decisive action of ha-adam as determining the names of the animals: "whatever ha-adam called each living nephesh, that was the name (2:19c)." ${ }^{69}$ She locates the narrative emphasis on the action of naming. I locate the narrative emphasis on the action of the discerning of and the deciding on an appropriate sexual partner. Other than this difference, we follow a similar feel for the narrative shape:

Without qualification, God relinquishes dominion to the earth creature. As a result, episode three [in Trible's structuring of the narrative] splits in the middle. Actions of divine world shape the first half (2:18-19b); actions of the human world the last (2:19b-20). But this split is more decisive for God than for the earth creature. Although the creature appears throughout the episode, first as object and then as subject, God is not mentioned at all in the second half. ${ }^{70}$

Trible goes on to elaborate on the agency of ha-adam though we differ on what ha-adam does with its agency. For Trible, the agency is restricted to naming; for Moore and I, the agency includes "finding" ( $m a t s a$ ) an appropriate sexual partner. Though Trible recognises that "[f]rom total passivity the earth creature has moved to active responsibility," she goes on to state, "Yet through it all this creature has not found a fitting companion." ${ }^{11}$ This is the narrative point, Moore and I would argue. For Trible, "episode three tantalises. Yahweh announces one agenda to precede immediately to another without explanation or apology. Then God disappears, and it is left to the narrator to conclude that the divine promise remains unfulfilled." ${ }^{\prime 2}$ But, I would argue, the narrative shape has made its point, namely that it is up to ha-adam to discern and decide whether what God has made is an appropriate sexual partner.

With this narrative point having been made, the implied reader is given another opportunity to bear witness to ha-adam's agency. God now does something different, working with the "flesh" (basar) of ha-adam itself. Trible finds a similar "circular design" in verses 21-24, with the word "flesh" delineating "the boundaries", occurring "once at the beginning, once at the end, twice in the middle, and nowhere else in the entire story"73 The repetition of basar and its framing of the literary sub-unit confirms a second act in the story of ha-adam's recognition and choice.

The focus remains firmly fixed on ha-adam's decision for God once again "brought" (bo) (vv.19 and 22) what God had "fashioned" (New American Standard Version) or "built" (banah) to ha-adam. I would argue that because the reader has read through the complication of verses 19-20, there is narrative tension as we wait to see what ha-adam will decide. Will there be a resolution? Will ha-adam find a companion and partner? The resolution 
lies not - given the narrative shift from the voice of the narrator in verse 22 to the voice of ha-adam who speaks for the first time - in what God fashions, a woman (ishshah), nor in God's action, that God brings ishshah to ha-adam, but that ha-adam makes it clear that it has "finally" found a companion and partner.

I emphasise, following Moore, the matter of recognition and choice. I accept that what ha-adam chooses is "a woman". But the narrative is clear that the poetic resonance between ish (man) and ishshah (woman) (v.23) is subsequent in narrative time to the narrator's signal of ha-adam's decisive speech ("and ha-adam said"). That ha-adam speaks decisively is a feature of the narrative. The shift from narrated prose to direct poetic speech emphasises what are two moments in the narrative movement. First, ha-adam speaks decisively, articulating a recognition and making a choice: "And ha-adam said" (v.23a). The second moment is itself in two parts. First, when we hear ha-adam's first sentence, we note that it is not about the specificity of what God has fashioned, but that what God has fashioned is "finally, bone of my bone/and flesh of my flesh" (v.23b). The first part of the second moment is a recognition of "fleshly" resonance. It is only in the second part of the second moment that a particular instance of fleshly resonance is poetically articulated: "This shall be called woman (ishshah)/ because from man (ish) was taken this" (v. 23c). This time there is a resolution to the aloneness of ha-adam. And who gets to decide that ha-adam is no longer alone? Not God, not the narrator, but ha-adam, using direct speech and speaking for itself.

The pronoun "itself" is instructive. At this point in the narrative as the narrative reaches its climax in resolving the complication of ha-adam's aloneness, it is ha-adam who speaks. As yet ha-adam is undifferentiated in terms of gender and sexual identity. So ha-adam speaks for all the possibilities that will emerge from this formative human creature God has made. And when ha-adam recognises, finally, a fleshly resonance (v.23b), the implied reader (both ancient and modern) might imagine the full array of gender and sexual diversity - for a moment. This is a significant moment, creating a space, a narratively constructed space, in which the implied reader may pause and reflect on a host of possible fleshly recognitions.

The narrative shape gives emphasis to ha-adam's decisive recognition. Only then does the narrative continue into hetero-normative territory. Just as the narrative resists but remains constrained by patriarchy, so too the narrative resists but remains constrained by heterosexuality. In terms of Moore's indecent question, verse 23ab is the narrative climax. Verse 23c and verse 24 then accommodate the narrative more overtly to the dominant hetero-patriarchal environment. Verse 23c does this by echoing ha-adam's "calling" (qara) of the animals (v.19), naming them, perhaps suggesting 'power over' and ha-adam's "calling" (qara) of ishshah, naming her. Trible resists this however, arguing instead that because the verb qara is used on its own and not together with the nominal "name", "in calling the woman, the man is not establishing power over her but rejoicing in their mutuality". ${ }^{4}$ 
Whether we recognise with Trible that verse 24 is part of her fourth episode, or whether we argue that this verse is an interpolation, ${ }^{75}$ the verses include indecent detail, but of a different kind. The "advent" of ishshah, Trible argues, "has transformed the earth creature into a sexual being" ${ }^{76}$ And this is what verse 24 is about:

The man's movement toward union with the woman involves its opposite: separation from the parents

... The result of this convergence of opposites is a consummation of union: 'and they become one flesh'. No procreative purpose characterizes this sexual union; children are not mentioned. Hence, the man does not leave one family to start another; rather, he abandons (azab) familial identity for the one flesh of sexuality. ${ }^{77}$

Trible follows the narrative logic of verse $23 \mathrm{c}$ - the celebration of female and male sexuality into verse 24. Her overall narrative summary, however, is worth reiterating: "The creation of humanity, sexually undifferentiated in episode one [2:7-8], finds its fulfilment in the creation of sexuality in episode four [2:21-24]." ${ }^{78}$ Moore and I would concur that there is enough indecent detail to indicate that the text can be read as "about" human sexuality in general rather than heterosexuality in particular. And if we make a methodological shift we might see this more clearly with respect to verse 24 .

\section{Indecent Socio-historical Detail}

The ancient implied reader of Genesis 2:24 would have been struck by its indecency. On what grounds would a man abandon his father and his mother (in that order) for a woman?

The long interpretive tradition, whether Jewish or Christian, of Genesis 2:24 shares, Megan Warner argues,

an underlying conviction that Gen 2:24 offers a normative definition (i.e. what must happen) as opposed to a description (i.e. what does happen) of marriage. They proceed from an understanding that the account of God's creation of the first couple in Genesis can be seen, in the light of Gen 2:24, to offer a blueprint for marriage that is applicable today. ${ }^{79}$

As Warner demonstrates, many biblical scholars have followed a similar line of argument that Genesis 2:24 is "etiological on a juridical (or normative) level", specifying what one must do. ${ }^{80}$ A minority position however has argued that Genesis 2:24,

is not a normative statement about the institution of marriage. Instead, they argue, Gen 2:24 presents an explanation of a phenomenon of nature, namely, 'the extremely powerful drive of the sexes to each other'. This 'powerful drive' is the result of the manner in which men and women were created and, in particular, of the fact that women and men were once a single entity, which was divided and which seeks unification. ${ }^{81}$

Claus Westermann, cited by Warner, comments on this text from the perspective "of the important role taken by parents in the arrangement of marriages for their children, which is evident 'from the patriarchal stories right up to the book of Tobit." Given this socio-historical 
reality, he and Warner argue, "The significance of the verse lies in this, that in contrast to the established institutions and partly in opposition to them, it points to the basic power of love between man and woman." ${ }^{\prime 2}$ Such scholarship discerns the improperness, perhaps even the indecency, of Genesis 2:24, recognising that this (interpolated) text,

does not set up a normative standard but rather explains the extraordinary strong force that causes those who marry or who otherwise embark in relationship to do so regardless of the normative standards that parents and society typically aim to enforce. This is a very different understanding of Gen 2:24 from that held by those who read Gen 2:24 as a normative definition of marriage. Far from being a 'conservative' prescription of how things must be (normative), Gen 2:24 becomes a radically honest appraisal of how things actually are (descriptive). The radical element of the appraisal lies in the fact that opposition to parental or societal authority is attributed to God's action in creation..$^{83}$

Warner continues immediately to state that, "The drive for the genders to be united, even if inconvenient, is the direct result of the creative activity of God." ${ }^{84}$ I would go further, following Moore's suggestive analysis, to state that the drive for sexual companionship and partnership both across and within genders, even if improper or even indecent, is the direct result of the creative activity of God. Warner herself follows a similar trajectory arguing that,

Far from setting out to regulate and restrict the institution of marriage, Gen 2:24 acknowledges, without narratorial censure of any kind, the propensity of men to pursue 'inappropriate' marriages that defy the wishes and schemes of their parents and, by implication, society and religious institutions. ${ }^{85}$

"Our study suggests," she continues, summarising the careful arguments of her article, "that the particular brand of inappropriate relationship that the authors of Gen 2:24 had in mind was intermarriage." "In our day," says Warner, moving from biblical text to contemporary context, "the presenting issue might be homosexual marriage, but the implication is the same - the cause of this propensity is to be located in God's solution to the problem of the aloneness of the adam." ${ }^{87}$

As with my literary analysis, my focus here is on socio-historical "shape". The shape of Genesis 2:24 is clear, even though different contexts may identify different "contents" within this shape. Genesis 2:18-23 and Genesis 2:24 share a similar shape. The aloneness of ha-adam recognises an appropriate, even if socially improper or indecent, sexual partner.

\section{Indecent Resources for Community Bible Study}

God, according to Genesis 2, recognised the aloneness of ha-adam and so created sexuality, granting the sexual creature God had created the right to recognise and choose its appropriate sexual companion and partner. Furthermore, Genesis 2 recognises that such sexual attraction does not always conform to familial and societal norms. 
Both literary and socio-historical analysis discern indecent detail in Genesis 2, but such detail is difficult to assemble for "ordinary" readers of Scripture. Among the tasks of the socially engaged biblical scholars working with poor and marginalised sectors is to find ways of offering this kind of detail in the form of questions that facilitate a slower and more careful re-reading of a particular scriptural text. ${ }^{88}$ What follows moves through the three intersecting sets of Contextual Bible Study's methodological processes. See-Judge-Act is the overarching framing movement - moving from (See) an analysis of social reality (in this case sexuality), to evaluating whether this reality conforms to a liberatory understanding of God's project (Judge), to forms of action (Act) that will change reality.

Within this frame, a second movement moves the Bible study from community consciousness to critical consciousness to community consciousness, embedding the Bible study in a particular local community. Closely associated with this second movement is a third movement, in which the critical resources of biblical scholarship offer resources to read the biblical text thematically, then to re-read the text more carefully, using literary resources, then (if appropriate) to re-read the text from a socio-historical perspective, and then finally to further re-read the themes that might be appropriated by the community from the detail of the carefully re-read text.

A Contextual Bible Study that is in the process of being constructed using the indecent detail of Genesis 2 has taken the following preliminary form:

1. Listen to Genesis 2:18-23. What is this text about?

2. Re-read Genesis 2:7 in as many different translations as you have in your small groups.

- How do your different translations translate this verse? Focus on the words used for the Hebrew ha-adam ('the man', 'the human', 'the earth creature', 'Adam' etc.)?

In Genesis 2:7 there is a play on words in the Hebrew: God creates an earth/ ground creature (ha-adam) from the earth/ground (ha-adamah). So a good translation might be "earth-creature" or "ground-creature":

7 And Yahweh God formed ha-adam (the earth-creature) of dust from ha-adamah (the earth) and breathed into its nostrils the breath of life and ha-adam became a living being.

- Do you think this translation is useful for your church and community?

3. Re-read Genesis 2:18-20 in your small groups using this translation:

And Yahweh God said,

18 "It is not good for ha-adam to be alone;

I will make for it a companion corresponding to it." 
19 And Yahweh God formed from ha-adamah every beast of the field and every bird of the heavens and brought each to ha-adam to see what it would call each one.

20 And whatever ha-adam called each living being, that was the name.

And ha-adam called the names of all domestic animals and the birds of the heavens and the beasts of the field.

But as for ha-adam, it did not find a companion corresponding to itself.

- What is the relationship between verse 18 and verse 19 ?

- Who decides what the animals' names are?

- Who also decides whether there is any among the animals that might be an appropriate partner?

4. Re-read Genesis 2:21-23 in your small groups using this translation:

21 And Yahweh God caused a deep sleep to fall upon ha-adam and, while it slept, took one of its ribs

and closed up flesh at that spot.

22 And Yahweh God built the rib

which Yahweh God took from ha-adam into woman (ishshah)

and brought her to ha-adam.

${ }^{23}$ And ha-adam said:

This, finally, is bone of my bone and flesh of my flesh.

This shall be called woman (ishshah)

because from man (ish) was taken this.

- Having tried the animals, what does God do next to find a partner for the earth-creature?

- Who decides that this new creature made from the body of the earthcreature is now the appropriate partner?

5. Re-read the whole text of Genesis 2:18-23 again.

There are two emphases in this story. First, there is an emphasis on the human "finding" or recognising its appropriate partner. It is the human creature who recognises its partner, using poetry to say, "This at last is bone of my bones, and flesh of my flesh." Second, there is an emphasis on the gender and sexual identity of the two creatures made from the one creature (ha-adam): a man (ish) and a woman (ishshah).

- Why have our churches made the second emphasis (the product) the main emphasis of the church's theology on sexuality?

- What would change if our churches placed an emphasis on the first emphasis (the process), recognising that God gives us as humans the right to identity an appropriate sexual partner? 
6. Read Genesis 2:24 using this translation.

24 Therefore, a man (ish) leaves his father and this mother and cleaves to his woman (ishshah) and they become one flesh.

Verse 24, which we have not yet read, suggests that the story has a third emphasis, an emphasis on sex. In biblical cultures, it is the woman who would leave her family and move to the man's family in marriage. But here it is the man who leaves his family! Therefore, the story is not about marriage but about the power of love, sexuality and sex. Such is the power of love, sexuality and sex; the story seems to be saying, that a man might even leave his family in order to be with his chosen partner.

- How can we help our churches to take sexuality and sex seriously?

- How can we help our churches to understand that sexuality and sex are a God-given gift?

- How can we help our churches to recognise that God grants us the right to identify our sexual partner?

This form of Contextual Bible Study (CBS) raises a number of distinctive challenges. First, this CBS requires the use of translations not already present in local communities and churches. This English re-translation and any similar local language re-translations would need to be accepted by the participants as working translations for the purposes of this CBS. Second, the CBS uses more 'input' than a typical CBS, given the provision of critical detail (both literary and socio-historical) not ordinarily available in local communities and churches. Participants would need to trust this input and accept it as part of the resources of the CBS. Third, the CBS ventures into taboo terrain, asking participants to tread where churches do not take them. In my experience, these challenges are in a descending order of difficulty. I do not think delving into the indecent is a significant problem provided the Bible leads the way, which I have argued the Bible does.

\section{Conclusion}

This essay has taken up Gareth Moore's recognition of a potentially indecent deconstructive reading of Genesis 2, in which the human creature that God has made articulates a decisive recognition and makes a decisive choice about its sexual partner. The significance of Moore's indecent recognition is that it is readily available to any careful reader of almost any translation of Genesis 2. It is readily apparent in the narrative shape of the story in its final form. This essay honours Moore's recognition and argument by elaborating upon them using literary and socio-historical resources. 
As our guide in the literary analysis of Genesis 2, we followed the pioneering gender-critical work of Phyllis Trible, honouring her too for her activist-biblical orientation, even when we discern a different indecent narrative within the literary detail she so carefully analyses. As our guide behind the text into the socio-historical world that produced our biblical texts, we followed Meg Warner, appropriating both her socio-historical detail and her socially engaged contemporary reflections on homosexual marriage.

I reserve the final word of acknowledgement for Marcella Althaus-Reid, whose indecent challenge to Latin American liberation theology has challenged all forms of liberation theology and liberation hermeneutics. This essay has not delved deeply enough into sexuality's intersections, but our text, Genesis 2, does offer potential sites of intersectionality, including sites of economic and ecological intersectionality. And if we were to go on to read further, following our story into Genesis 3 and 4, we would be confronted more forcefully with the economic, as our colleagues Gunther Wittenberg and Itumeleng Mosala have made clear. ${ }^{89}$ The indecent intersection between gender, sexuality, and economics is incipient in what we have read, and because these intersections shape the lives of our communities and churches, we have to engage with them - no matter how difficult and indecent the challenges.

\section{Bibliography}

Althaus-Reid, Marcella. Indecent Theology: Theological Perversions in Sex, Gender and Politics. London and New York: Routledge, 2000. https://doi.org/10.1177/0040571X0010300520

Aristotle. Poetics. Translated by Gerald F. Else. Ann Arbor, MI: The University of Michigan Press, 1967.

Chitando, Ezra. "A New Man for a New Era? Zimbabwean Pentecostalism, Masculinities, and the HIV Epidemic." Missionalia 35/3 (2007): 112-127.

Clines, David J.A. "Reading Esther from Left to Right: Contemporary Strategies for Reading a Biblical Text. Pages 3-22 in On the Way to the Postmodern: Old Testament Essays, 1967-1998. Edited by David J.A. Clines. Sheffield: Sheffield Academic Press, 1998.

Lanser, Susan S. "(Feminist) Criticism in the Garden: Inferring Genesis 2-3." Semeia 41 (1988): 67-84.

Moore, Gareth. A Question of Truth: Christianity and Homosexuality. London: Continuum, 2003.

Mosala, Itumeleng J. Biblical Hermeneutics and Black Theology in South Africa. Grand Rapids, MI: Eerdmans, 1989.

Nadar, Sarojini. "Palatable Patriarchy and Violence against Wo/men in South Africa: Angus Buchan's Mighty Men's Conference as a Case Study of Masculinism." Scriptura 102/1 (2009): 551-561.

Stone, Ken, ed. Queer Commentary and the Hebrew Bible. Cleveland, OH: The Pilgrim Press, 2001.

Stratton, Beverly J. Out of Eden: Reading, Rhetoric, and Ideology in Genesis 2-3. Sheffield: Sheffield Academic Press, 1995.

Trible, Phyllis. God and the Rhetoric of Sexuality. Philadelphia, PA: Fortress, 1978.

Von Rad, Gerhard. Genesis: A Commentary. Translated by John H. Marks. Philadelphia, PA: Westminster, 1961.

Walsh, Jerome T. Old Testament Narrative: A Guide to Interpretation. Louisville, KY: Westminster John Knox Press, 2009.

Warner, Megan. "Therefore a Man Leaves His Father and His Mother and Clings to His Wife': Marriage and Intermarriage in Genesis 2:24." Journal of Biblical Literature 133/2 (2017): 269-288. https://doi.org/10.15 699/jbl.1362.2017.241017

West, Gerald O. Biblical Hermeneutics of Liberation: Modes of Reading the Bible in the South African Context. Second editon. Maryknoll, NY and Pietermaritzburg: Orbis Books and Cluster Publications, 1995. 
West, Gerald O. "Deploying the Literary Detail of a Biblical Text (2 Samuel 13:1-22) in Search of Redemptive Masculinities." Pages 297-312 in Interested Readers: Essays on the Hebrew Bible in Honor of David J.A. Clines. Edited by James K. Aitken, Jeremy M.S. Clines and Christl M. Maier. Atlanta, GA: Society of Biblical Literature, 2013. https://doi.org/10.2307/i.ctt5viz47.25

West, Gerald O. The Stolen Bible: From Tool of Imperialism to African Icon. Leiden and Pietermaritzburg: Brill and Cluster Publications, 2016. https://doi.org/10.1163/9789004322783

Westermann, Claus. Genesis 1-17: A Commentary. Translated by John J. Scullion. Minneapolis, MN: Augsburg, 1974.

Wittenberg, Gunther H. Resistance Theology in the Old Testament: Collected Essays. Pietermaritzburg: Cluster Publications, 2007.

\section{Endnotes}

1 Gareth Moore, A Question of Truth: Christianity and Homosexuality (London: Continuum, 2003), 134.

2 Ibid, 138.

3 lbid.

4 Ibid.

5 Ezra Chitando, "A New Man for a New Era? Zimbabwean Pentecostalism, Masculinities, and the HIV Epidemic," Missionalia 35/3 (2007): 1 12-127. Sarojini Nadar, "Palatable Patriarchy and Violence against Wo/men in South Africa: Angus Buchan's Mighty Men's Conference as a Case Study of Masculinism," Scriptura 102/1 (2009): 551-561.

6 Moore, A Question of Truth.

7 West, The Stolen Bible: From Tool of Imperialism to African Icon (Leiden and Pietermaritzburg: Brill and Cluster Publications, 2016), 337-347, 380, 392.

8 Moore, A Question of Truth, 139.

9 Phyllis Trible, God and the Rhetoric of Sexuality (Philadelphia: Fortress, 1978). Susan S. Lanser, "(Feminist) Criticism in the Garden: Inferring Genesis 2-3," Semeia 41 (1988). Beverley J. Stratton, Out of Eden: Reading, Rhetoric, and Ideology in Genesis 2-3 (Sheffield: Sheffield Academic Press, 1995).

10 Moore, A Question of Truth, 139.

11 lbid.

$12 \mathrm{lbid}$. As I will indicate more fully below, I would want to interrogate the intersection between sex and work more fully following as I do in this essay the "indecent" trajectory of Marcella Althaus-Reid.

13 Ibid.

14 Ibid.

15 Ibid.

16 Ibid, 139-140.

$17 \mathrm{lbid}, 140$.

$18 \mathrm{lbid}$.

19 Ibid.

20 Ibid.

21 Ibid.

22 Ibid.

23 lbid, 140-141.

$24 \mathrm{lbid}, 141$.

$25 \mathrm{lbid}$

$26 \mathrm{lbid}$

$27 \mathrm{lbid}, 142$.

28 Ibid.

29 lbid, 143

30 Ibid.

$31 \mathrm{lbid}, 144$. 
32 Ibid.

$33 \mathrm{lbid}, 145$.

34 Ibid.

35 Ibid.

36 lbid.

37 Ibid.

$38 \mathrm{lbid}$.

39 lbid.

$40 \mathrm{lbid}, 146$.

$41 \mathrm{lbid}, 66-117$.

42 Marcella Althaus-Reid, Indecent Theology: Theological Perversions in Sex, Gender and Politics (London and New York: Routledge, 2000), 2.

$43 \mathrm{lbid}, 3$.

44 lbid.

$45 \mathrm{lbid}, 5$.

46 Ibid.

$47 \mathrm{lbid}, 7$.

48 lbid, 95.

$49 \mathrm{Ibid}, 168$. See also Ken Stone, ed., Queer Commentary and the Hebrew Bible (Cleveland, $\mathrm{OH}$ : The Pilgrim Press, 2001), 33.

50 Aristotle, Poetics (transl. Else; Ann Arbor: The University of Michigan Press, 1967), 30, David Clines, "Reading Esther from Left to Right: Contemporary Strategies for Reading a Biblical Text," in On the Way to the Postmodern: Old Testament Essays, 1967-1998, ed. D. Clines (Sheffield: Sheffield Academic Press, 1998), 5. Jerome T. Walsh, Old Testament Narrative: A Guide to Interpretation (Lovisville: Westminster John Knox Press, 2009), 14.

51 Here and in what follows, I will be using Phyllis Trible's translations in honour of her pioneering work nearly forty years ago; Trible, God and the Rhetoric of Sexuality.

$52 \mathrm{lbid}, 88$.

$53 \mathrm{lbid}, 90$.

54 Ibid.

55 Ibid.

56 lbid, 93.

57 lbid, 90.

58 lbid.

59 lbid.

$60 \mathrm{lbid}, 90-91$.

61 lbid, 91.

62 lbid.

$63 \mathrm{lbid}$.

$64 \mathrm{lbid}, 88$.

$65 \mathrm{lbid}, 93$.

$66 \mathrm{lbid}$.

67 lbid.

$68 \mathrm{lbid}, 92-93$.

69 lbid, 93.

70 lbid.

71 lbid, 94.

72 lbid.

73 Ibid. Trible's careful and creative literary analysis of this entire "episode" is worth revisiting but is beyond the scope of this essay. 
$74 \mathrm{lbid}, 100$.

75 Megan Warner, "'Therefore a Man Leaves His Father and His Mother and Clings to His Wife': Marriage and Intermarriage in Genesis 2:24," Journal of Biblical Literature 133/2 (2017): 273.

76 Trible, God and the Rhetoric of Sexuality, 104.

77 Ibid.

78 Ibid. I agree with Trible in allocating Genesis 2:25 to the next episode as the exposition from which the complication of Genesis 3 arrives.

79 Warner, "Marriage and Intermarriage in Genesis 2:24," 271-272.

80 Ibid, 274.

81 Ibid, citing G. von Rad, Genesis: A Commentary (transl. Marks; Philadelphia: Westminster, 1961). The emphasis is Warner's.

82 Warner, "Marriage and Intermarriage in Genesis 2:24," 274, citing C. Westermann, Genesis 1-11: A Commentary (transl. Scullion; Minneapolis, MN: Augsburg, 1974), 233. The emphasis is Warner's.

83 Warner, "Marriage and Intermarriage in Genesis 2:24," 275. Warner goes on to make a compelling argument for Genesis 2:24 as an interpolated text that was generated in contestations concerning intermarriage.

84 lbid.

85 lbid, 289.

$86 \mathrm{lbid}$.

87 lbid.

88 See for example Gerald West, "Deploying the Literary Detail of a Biblical Text (2 Samuel 13:1-22) in Search of Redemptive Masculinities," in Interested Readers: Essays on the Hebrew Bible in Honor of David J.A. Clines, ed. James K. Aitken et al. (Atlanta, GA: Society of Biblical Literature, 2013), 297-312.

89 Gunther H. Wittenberg, Resistance Theology in the Old Testament: Collected Essays (Pietermaritzburg: Cluster Publications, 2007), 15-19. Itumeleng Mosala, Biblical Hermeneutics and Black Theology in South Africa (Grand Rapids, Ml: Eerdmans, 1989), 33-37. Gerald West, Biblical Hermeneutics of Liberation: Modes of Reading the Bible in the South African Context (Maryknoll, NY and Pietermaritzburg: Orbis Books and Cluster Publications, 1995), 64-82. 


\section{HAVING DIFFICULT CONVERSATIONS \\ Engaging Film as a Reflective Surface to Encourage Dynamic Intersectional Encounters ${ }^{1}$}

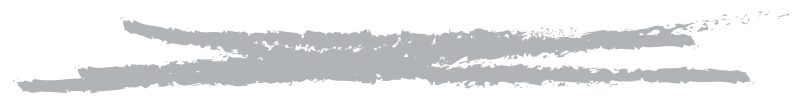

Charlene van der Walt School of Religion, Philosophy and Classics University of KwaZulu-Natal

\section{Creating Space for Difficult Conversations}

Having the opportunity to take a step back, to view the well-known overfamiliar realities and landscapes that we are embedded in from a new vantage point or from a different perspective, is not a luxury we are often afforded or a risk that we are frequently willing to take. Yet, the gift of the opportunity to write this essay and to have these precious moments of reflection invites me to take the risk of stepping out of the continuous forward motion of doing scholarship, of being engaged with the teaching and implementation of transformative pedagogies and of asking questions such as: How did we get here? What are we busy with? What is the change we want to see? Does our process reflect the theoretical underpinnings and values that inform our scholarship? By trying to answer these questions, this essay serves as a critical pedagogical reflection on praxis. I am simultaneously thankful for the crazy immersed-ness and the collective becoming that this pedagogical journey has been and for this rare moment to take a step back and to reflect critically on some of the insights gained in this process of becoming and of co-constructing. ${ }^{2}$

The journey started in 2012 when the Faculty of Theology at Stellenbosch University, South Africa in conjunction with other African academic partners was approached by representatives of the Church of Sweden to start a new research focus in their existing MTh programme that would explore the intersection of Gender, Health and Theology within our local context. ${ }^{3}$ The impetus for this initial request was the eagerness on the part of the Church of Sweden in collaboration with the Swedish Government Development Agency (SIDA) to find ways of addressing two of the United Nations' Millennium Goals, namely the reduction of child mortality and the improvement of maternal health. ${ }^{4}$ 
The request and accompanying Concept Note for the initial Pilot Program Gender and Health dynamically informed the development of the special-focus Master's programme and the pedagogical exploration that it implied. ${ }^{5}$ Two key imperatives played an important role in the conceptual pedagogical development of the Master's programme. First, the contextual gendered nature of the central concern, namely maternal health and child mortality, that had to be addressed by the programme aligned well with the imperative of a Feminist Theory of Praxis as proposed by amongst others Denise Ackermann. The theory insists that theological reflection should be primarily informed by the embodied lived realities of those most vulnerable in society. ${ }^{6}$ The resolve to link African academic partners with local contextual community partners and Faith-Based Organizations implied not only that the "most vulnerable" did not simply remain a vague conceptual abstraction, but that concepts or ideas have names and faces - became embodied. The programme would thus be informed primarily by the realities of those most affected by the complex intersection of Gender, Health and Theology.

Second, maternal health and child mortality are not issues that can be discussed in isolation, but require methodological approaches and theoretical frames that can engage with the complex constellation of factors that bring these realities about. ${ }^{7}$ The concept of intersectionality has been paramount in the sense that it maintains that in order to comprehensively deal with embodied experiences of oppression, domination and marginalisation, one has to take into consideration how multiple social forces such as race, class, gender, sexual orientation, religion and culture converge in order to bring into being a certain phenomenon, position or situatedness. ${ }^{8}$ The initial discussion pertaining to maternal health and child mortality in Africa as an example of contextual issues situated within the intersection of Gender, Health and Theology soon became a much more complicated and dynamic conversation involving race, gender, class, sexual orientation, socio-economic status, history, culture and religion.

Needless to say, and linking to the intersectional nature of the programme, no single discipline or theoretical vantage point could contain the complexity of the discussion and it soon became clear that we would have to reflect on these issues by employing discipline-specific tools in a dynamic interdisciplinary and transdisciplinary manner. ${ }^{9}$ The fact that the programme had to slot into our existing Master's programme frame at Stellenbosch University resulted in a vibrant, albeit sometimes painfully complex dynamic where gender issues got increasingly mainstreamed and where creative interdisciplinary and transdisciplinary conversations were made possible between students and staff from various disciplines.

Instrumental to the establishment of the programme was the development and implementation of the Core Module Gender and Health that has been taught to a group 
of gender and culturally diverse students each year since its inception in 2013. Having the opportunity to develop and implement the Core Module Gender and Health was like receiving the gift of a blank canvas, and it was from its inception strongly informed by the vision that guided the programme. ${ }^{10}$ The vision has become increasingly more nuanced in its expression, and can probably be best summarised by employing the title of the initial conference and of this current and subsequent publication, namely "cultivating change agents", and by tracing how it is unpacked within the promotional material pertaining to the MTh Gender and Health at Stellenbosch University, which states that: The aim is to cultivate change agents who in their respective communities will help bring about a change in attitudes and actions with regard to the complex intersection of Gender, Health and Theology.

Since 2013, I have had the remarkable and humbling privilege to encounter annually a group of students who are intuitively drawn to the complexity of issues situated within the intersection Gender, Health and Theology. As existing or potential community leaders, they express upon arrival an instinctive and embodied knowledge that something is horribly wrong in a world where a virus becomes a moral issue, where women and girls are valued less, where black lesbians in South African townships need to be "corrected" through rape because they do not fit the heteronormative ideal, or where people are excluded from the community of faith because of who they love and of where they find community. Although our students might know these things in a deeply existential way, they often lack the vocabulary or words to express the issues and in the light of the overwhelming life-denying realities that manifest at the intersection, they are often too breathless to speak. While they are keen to impact this landscape, they frequently voice their inability to find appropriate vocabulary to name their lived experiences or to engage with the unquestionable norms that predominately govern hetero-patriarchal societies and faith communities.

Informed by insight from feminist theory, the pedagogical process aims to honour and acknowledge this initial intuitive insight and to respect the pre-existing embodied knowledge represented by the lived experiences of each of the students present in the class. Students are invited to become part of a communal process of exploration and discovery whilst being aware of their unique vantage point and the particularity of their position.

In terms of content, the module aims to enhance, extend and deepen the vocabulary and theoretical insight of students pertaining to gender and sexuality, to empower students with a variety of theoretical tools to engage complex issues at the intersection of Gender, Health and Theology and to insist on engaging with these issues in a complex fashion. Informed by insight from Queer scholarship, students are encouraged to trouble and destabilise the often-unquestionable norm and to move beyond simple binary or dualistic constructions or judgements. The module insists on constant reflection on power dynamics and in the 
process encourages scholarship that functions in a way that troubles, destabilises, questions, pushes back and in the process deliberately challenges dominant ways of speaking, writing and being. All of these processes develop and grow within a diverse community of voices represented by those present in the class and by the richness of the theoretical voices introduced through reading and other content sharing methods.

The content and theoretical insight explored above informs the movement that can be traced in the Core Module. The initial focus on the development of vocabulary and theoretical engagement tools gives way to the construction of complex conversations relating to specific issues embodied within the intersection Gender, Health and Theology, namely HIV and AIDS, Gender-Based Violence, Disability, Queer-lived realities and, since 2014, complex and contextually informed construction of Masculinities.

The inclusion of masculinity construction as one of the complex contextual issues for comprehensive reflection was informed firstly by theoretical insight developed from feminist scholarship, which highlights that it is not only women who suffer due to patriarchy. Findings show that the impenetrable hyper-masculine ideal as constructed within hetero-patriarchal discourse is often not only detrimental to women, but harms men and limits the possibility for non-conforming diverse communities of care to come into being, that is, communities informed by the communal embodied experiences of diversity and vulnerability.

Second and possibly more influential to my inclusion of Masculinity studies was my own encounter with the 2011 film Skoonheid by Cape Town-born, South African writer/director Oliver Hermanus. ${ }^{11}$ Skoonheid is a story that develops from and depicts a certain segment of the South African society and uncompromisingly interrogates hegemonic constructions of Afrikaner masculinity that can be described as a gender construct that is so absolute in its production that little room is left for alternatives or exceptions. Theo Sonnekus remarks on the masculinity construction portrayed in Skoonheid as follows:

Such performances of hegemonic Afrikaner masculinity can thus be viewed as manifestations of Christian Nationalist ideology, buttressed mainly by the Dutch Reformed Church, which placed great emphases on morality, asceticism, industriousness, and heteronormativity. ${ }^{12}$

In Skoonheid, I found the proverbial rug that tied the room together in the sense that it gifted us with a narrative that skilfully and painfully depicts a character constructed so tightly within a specific race ideologically informed cultural construction of heteropatriarchal normativity that it is not surprising that no real life is possible for those who realise that they do not fit the pinned-up ideal. Francois van Heerden (Deon Lotz) has been a discomforting gift that forced me and my students to grapple annually with the embodied trauma of one painfully situated at the complex intersection of gender, health and theology. 
In order to nuance the pedagogical praxis reflection in the last part of the essay, I will briefly discuss the plot of the film and refer to key thematic issues relevant for understanding the film as a reflective surface for a discussion of masculinity construction. ${ }^{13}$

\section{Difficult Conversation Matter - Engaging with Skoonheid}

Skoonheid was the first Afrikaans film to be screened at the Cannes Film Festival and it won the Queer Palm for its contribution to Queer cinema in 2011. Following his award-winning 2009 film, Shirley Adams, in Skoonheid (which can be translated as 'Beauty') Hermanus again focuses on a character for whom there seems to be no easy way out of things. ${ }^{14}$ In the translation of the film's title into English, something of the fine nuance of the title is lost, however. The film indeed explores beauty as in physical beauty, but a second, more subtle meaning of the word skoonheid in the original Afrikaans is the word 'cleanliness' as in being clean. ${ }^{15}$ Read in the context of the South African landscape, this cleanliness can be interpreted as being white, as being separate and as being set aside. In this regard, Shaun de Waal remarks that, "The upright godly morality, or at least its degenerated but socially binding descendent, which would value "cleanliness", is strongly present in Skoonheid. It is the very marrow of white Bloemfontein ..."16

The film subtly explores this second meaning of the word Skoonheid as we often find the main character washing and urgently scrubbing himself, somehow trying to rid himself of the dirty feeling or desires that he secretly harbours.

Many have commented on the pace of the film and Lin Sampson aptly remarks in this regard that, "The film is slow paced. This, combined with its cinemascope screen, brings it very close, sometimes too near for comfort in a purposeful ploy." ${ }^{17}$ As Sampson notes, the ploy masterfully constructed by Hermanus is that the viewer is drawn in and becomes a sort of voyeuristic eyewitness to the slow unravelling of Francois van Heerden. Hermanus in his Director's Note comments on the privileged position of the viewer thus:

The story is very much the exploration of one man's self-destruction. His disdain for himself. His hatred. We are privy to the different, compartmentalized sections of his life, his secrets and his desires. We witness his violence, his fears, his anger and his jealousy. ${ }^{18}$

We meet Francois, the main character of the film supremely portrayed by Deon Lotz, at the wedding reception of his eldest daughter. The film starts with arguably one of the most spectacular shots of the entire project as the camera slowly moves across the wedding guests when they start making their way to the main reception hall. The shot, which lasts quite a while, slowly zooms into its main perspective to reveal a beautiful young man, named Christian (Charlie Keegan). This lingering shot and its flow is one of the visual highlights of the film. 
It is only in retrospect that the viewers realise that they were seeing the world though Francois' eyes. This initial scene sets up the status quo for the rest of the film. Francois van Heerden appears in every single scene of the film and is the viewer's guide through his world. At first glance,

Francois is a successful 41-year-old family man. He has two beautiful daughters, a devoted wife, and a prosperous timber business. As far as everyone is concerned he is the definition of what a stable man should be ... which, of course, means that Francois is hiding something. ${ }^{19}$

We are gradually introduced to the neatly compartmentalised life that Francois has constructed. Francois stays in Bloemfontein, South Africa's Afrikaner heartland. ${ }^{20} \mathrm{He}$ is married to Elena (Michelle Scott) though they seem not to have an intimate or physical relationship. The sterile bankruptcy of their relationship is stunningly portrayed in the film through mundane conversations with a slightly aggressive undertone as they lie together, yet completely separate, in bed at night. The distinct lifeless tone of their conversation comes into sharp focus when Elena leaves a dinner-table conversation with Francois to answer the phone and the joyful tone in her voice is heard off-screen, while Francois stays behind in silence at a dimly lit dinner table.

From snippets of dinner-table conversation, we might suspect Francois to be homophobic and racist. Therefore, Lee Marshall poignantly remarks:

When he drives to a farmstead meeting with a group of tongue-tied roughnecks, we assume it's a white supremacists' hoedown, especially when one of the group is turned away because he has broken their 'no faggots or colored's' ${ }^{21}$ rule by arriving with a fey black boy in tow. ${ }^{22}$

It thus comes as quite a shock when in the next scene we see Francois and his hard Afrikaner pals engaged in an orgy, while gay porn plays on TV and overpowers the soundtrack. They are indeed "... hard, homophobic men who like to have sex with each other, before (like Francois) going back to their families, going to church and behaving like regular guys".23

Although the construction of Francois' sexual identity warrants investigation, it falls outside the scope of this essay and I will, therefore, only allude to this very important dimension of Francois' character in a couple of superficial remarks. Francois does not regard himself as homosexual. He hates moffies, ${ }^{24}$ but enjoys having sex with men. He distances himself from homosexuality, ${ }^{25}$ identifying himself instead as a "straight man that has sex with men". The film demonstrates Francois' struggles to deal with his desires, which run counter to his cultural upbringing as a traditional Afrikaner with deeply embedded, conservative, heterosexual values.

In the film director's note, Hermanus explains his understanding of Francois' character:

François should not be easily dismissed or relegated to being a 'negative character'. My intention as the filmmaker is to explore his contorted and troubled existence in showing his tragedy and his brutality without judging him. The reality of this character in post-apartheid South Africa is that he 
represents a minority grouping in a country that was ruled by the minority for centuries and now is ruled by the majority. Francois speaks a language that is not spoken in any other part of the world; he has a heritage that is stigmatized as being racist and hateful. He was raised to be wary of the black man and to embrace conservative values. He lives in a city that was once the capital of this regime, and is still a bastion of its former glory. Francois fears the country he lives in because he is perceived as the guilty party, the color of his skin, the language he speaks, the blood that runs through his veins is all symbols [sic] of a brutal unjust past. The collective guilt and subconscious need to defend their heritage are what most conservative Afrikaners battle with every day ... and beyond this, Francois, like millions of men around the world, is humiliated and ashamed of his sexual preference. The combination of these imploding tensions and the mastery of his ability to control his emotions is the starting point of this film. ${ }^{26}$

But when Francois meets Christian, the son of an old family friend at his daughter's wedding, his resolve crumbles and he suddenly loses control of his boundaries and breaks his own carefully constructed and self-protecting rules. Francois becomes obsessed with this beautiful young man. Charlie Keegan is perfectly cast as the object of Francois' desires, youthful and disarming in his charm. Hermanus places him at the centre of every shot in which he appears in the film with the camera focusing on his strong masculine beauty and casting him as though through Francois' gaze. Christian is a man born with physical form and beauty that gives him power in the world and it could be argued that this gives him currency to manipulate and take what he wants from the world.

Francois is a voyeur and we spend a great deal of time looking at Francois as he looks at other people or seeing the world from Francois' perspective. We follow Francois from Bloemfontein to Cape Town as he continues his pursuit of the object of his desire. Christian is arguably painfully unaware of Francois' feelings as he continues to engage pleasantly with Francois in order to secure the opportunity to act as his company's lawyer after he has completed his tertiary law studies. Francois is in turn disarmed and disrupted by the spell of Christian's power of beauty. He wants to be with him, manipulates situations to be near him, to possess him. Yet, the ease with which Christian floats through life, the charm of his easy manner, enrages Francois to the core. Francois is simultaneously drawn to Christian and repulsed by him. We look at Francois spiralling closer and closer to Christian as we carefully tiptoe towards the end - that pervading feeling of dread builds to a graphic and unsettling climax that is both shockingly violent and painfully inevitable. It borders on unwatchable as Hermanus again employs long unflinching camera shots but, rather than being gratuitous, it feels like an entirely necessary and graphic conclusion to Francois' story.

Francois violently takes what he wants. The apparent desire for a thing of beauty, for an object of affection is exposed as a lie in the ultimate act of violence as his obsession leads him to rape Christian. That which starts out as something, described in words belonging to the discourse of love and desire, ends as an act of violation, violence and power. 


\section{Having the Difficult Conversation and Dealing with Discomfort}

Simply from this brief description of and reflection on the violently complex reflective surface that we encounter in Hermanus' film we probably can sense why viewing the film is situated within the Core Module as a culmination point of sorts. Comprehensive engagement with the film implies the convergence of various strains of complex theory and poses a great theoretical and conceptual challenge to the viewers. One cannot engage with the complex dynamic of Francois' character without bringing into play theories pertaining to race, class, gender, sexual orientation, masculinity construction, culture, history, religion, gender-based violence, homophobia and privilege.

The inclusion of Skoonheid within the Core Module curriculum was informed by the pedagogical insight that diverse narratives hold great potential for imaginative contextual ethical reflection and the development of moral imagination as Martha Nussbaum proposes. ${ }^{27}$ Truly grappling with our own feelings of isolation and disconnection in the process of negotiating our construction of sexuality may seem such a daunting task that we rather choose to continue to live in ignorant yet unexamined bliss. By seeing various narratives as reflective surfaces, like the one we encounter in Skoonheid, viewers are invited to enter a dynamic space to confront complex and painful personal lived realities. ${ }^{28}$ In the encounter with characters who find themselves isolated, perplexed or disenfranchised within the narrative, interpreters/viewers may be encouraged to reflect on their own experience of isolation and complex identity construction. In contemplating the painful embodiment of the character of Francois van Heerden embedded within the narrative and the seemingly unquestionable norms that govern his world, we might find a productive space to reflect on our own embodied realities, our own negotiations of hetero-patriarchy. By looking into Francois' world the so-called "water that we swim in" and that we are generally painfully unaware of becomes the object of analysis.

Francois' story becomes a tool that we can use to name and examine the often-invisible contours of patriarchy, heteronormativity and hyper-masculinity. Through the act of viewing, interpretation and discussion, the messy, complex and painful world depicted in the film becomes a dynamic space for ethical reflection and contemplation by contemporary viewers.

However, on her experience of viewing the film, Samantha Steele from the Mail and Guardian remarks that, "It is difficult to watch. It's a difficult enough subject to grapple with at the best of times but Hermanus's graphic representations - the orgy and a disturbing rape - make it impossible to look away." ${ }^{29}$

Even Deon Lotz who played the main character, Francois van Heerden, and Charlie Keegan who played the object of his desire, Christian, found some of the more violent physical 
scenes difficult to watch. Steele quotes the actors: “I get goosebumps just thinking about it', says Lotz. Says Keegan: 'It's not easy to watch yourself in a scene that [depicts a situation] you wouldn't want to see anyone in." ${ }^{30}$

In the final part of the essay, I would like to highlight the notion of viewers' discomfort as referred to by Steel, Lotz and Keegan when engaging with the reflective surface of Hermanus' film. ${ }^{31}$ When asked to reflect on the experience of viewing the film and engaging with the content of the film in a three-page writing assignment, students employ terms such as 'painful,' 'challenging,' 'violating, 'disturbing,' 'troubling' and 'difficult' to explain their encounter with the film. ${ }^{32}$ They unwittingly reflect on the style of Hermanus' filmmaking saying, "the director forces the viewer to watch". The discomfort expressed by reviewers of the film and actors involved in the project is echoed by students in their reflection on the experience. As one student writes:

The film is not for the faint-hearted: it leaves one silent and pensive, if not shocked. It touches on themes of identity and community, and deconstructing those in a clever way can dig deep into a viewer's sense of security. The film furthermore explores sexual themes like desire, lust and sexual orientation - all of those such an integral part of being human. And when we view rape - at once the crisis and highpoint of the story, we also feel violated. Nevertheless, maybe we need to sometimes really see before we can begin to understand.

Another remarks that, "It is an intense film that leaves one shaken and filled with questions. Some may even view it as 'a quiet film' that makes no judgements, but encourages its audience to raise more questions than answers." Yet, another states that, "It truly is an intense and challenging film, shaking the safe foundation in our lives while addressing numerous de-humanizing factors in our broken society." Another student remarks that, "In the first place the film was very disgusting to me especially the sexual violence - the raping of the young man Christian. It shows that everyone is vulnerable, not only women and children."

The discomfort voiced in the written reflections is nothing but a shadow of the often emotional reflections offered by students in the pivotal debriefing session, which annually follows the viewing of the film. Considering the emotionally charged nature of the viewing and discussion experience, it seems appropriate to offer a side note regarding the process of facilitating the viewing of the film. I am aware of the potential risk involved in showing the film in the sense that it can possibly hit too close to home for students considering the subject matter and the potential risk of re-traumatisation for survivors of gender-based violence. Hence, I try to contain the viewing experience by first offering students as much appropriate background information and appropriate theory as possible in order to help them engage with the subject at hand. ${ }^{33}$ Subsequently, I try to keep the class together with a meal after the viewing in order to create a safe and caring co-constructed environment and by holding the space for students in an uncensored debriefing session after the viewing, which is aimed at assisting students in the process of re-orientation and integration. 
Pedagogically, however, I take the calculated risk of facilitating the viewing of the film drawing on the work by Megan Boler, ${ }^{34}$ Ann Berlak ${ }^{35}$ and Michalinos Zembylas ${ }^{36}$ on the so-called pedagogy of discomfort. Zembylas and McGlynn state that:

A pedagogy of discomfort, as an educational approach, emphasizes the need for educators and students alike to move outside their 'comfort zones'. Pedagogically, this approach assumes that discomforting emotions play a constructive role in challenging dominant beliefs, societal habits and normative practices that sustain social inequities and in creating possibilities for individual and social transformation. ${ }^{37}$

Theoretically, the model implies that it is necessary to offer students the opportunity to 'unpack their cherished worldviews and 'comfort zones' in order to deconstruct the ways in which they have learned to see, feel and act" ${ }^{38}$ By closely problematising these emotional habits, it is hoped that teachers and students will begin to identify their unconscious privileges, as well as the invisible ways in which they comply with dominant ideology. Consequently, the value of this pedagogical approach is particularly effected when harnessed in settings dealing with or engaging with social justice issues.

By drawing on the theoretical insights offered above in terms of a pedagogy of discomfort, in conclusion I would like to reflect briefly and personally on a number of issues as a form of pedagogical praxis reflection on our communal annual exercise in discomfort when viewing and engaging with Skoonheid. In the process, I identify and briefly explain three strands that I believe warrant further exploration in future.

First, I would like to reflect on the transformational potential that seems to result from uncomfortable pedagogical encounters which enables those affected to move from "passive empathy" to "critical hope". Here, I draw on the work of Ann Boler who describes critical hope as an emotional willingness to engage in the difficult work of possibly allowing one's worldview to be shattered, thus creating space for individuals to suspend judgement for a moment and resist binary oppositional categorisation in order to develop the capacity to imagine the reality and embodiment of another's situation. ${ }^{39}$ Creating space is an attempt to cultivate empathy as counter to stigmatisation and dehumanisation that so often occupy religious discussions and decisions pertaining to sexual diversity and other complex issues at the intersection of gender, health and theology.$^{40}$ Finn Reygan and Dennis Francis draw on the work of Boler in their claim that,

A pedagogy of discomfort provides new perspectives on the world, guiding learners and teachers to step out of their 'comfort zones' and away from strongly held beliefs so as to critique the manner in which they have been taught to feel, see and act. ${ }^{41}$

This shift in position can be traced in a student's writing reflection:

The sympathy that the film evokes for the main character becomes a door through which we may enter a room of self-interrogations: What do I believe? Is it a fair and just and true thing to believe? Do my actions show what I believe? Do I contribute to a healthy and safe society, or am I detrimental to it?" 
Another student says, "This film makes you think about your actions and your life in a different way and it confronts you with the dualistic question of whether Francois is a villain or a victim of his circumstances or both?"

Michael White suggests that when people risk suspending personal opinion and judgement and stand together in solidarity, however briefly and partially, it "... provides us with the opportunity to look back on our taken-for-granted ways of thinking and being in the world." ${ }^{42}$ White believes that this makes it possible for people to:

... think outside the limits of what we would otherwise think, to challenge aspects of our own participation in the reproduction of dominance, and to identify options for action in addressing disadvantage and inequality that would not otherwise be available to us. ${ }^{43}$

Second, and in relation to the seminal work by Michalinos Zembylas concerning this dimension of the pedagogical process, I am concerned about the ethical dimensions of setting up uncomfortable and ideologically challenging pedagogical spaces. ${ }^{44}$ The reflection by Zembylas resonates with this concern:

On the one hand, there is the tension of recognizing that discomfort may be inevitable, if transformation is part of our pedagogical vision and praxis; on the other hand, one cannot but wonder how ethically responsible it is to create conditions of discomfort, pain, and suffering in students in the name of ethical norms - no matter how 'noble' they might be. ${ }^{45}$

Being witness to the real experiences of distress and discomfort by students in response to viewing the film underlines the importance of continuous reflection on the meaning and protection of classroom safety. Creating communal, responsible and accountable pedagogical spaces of trust and safety that will encourage students to lean into discomfort and to nurture the process of change seems paramount. As Zembylas puts it, “... safe space, then, is not about the absence of discomfort, but rather it is a way of thinking, feeling and acting that fosters students' critical rigor." ${ }^{46}$

\section{Conclusion}

In this essay, I have outlined something of the journey of the MTh Gender and Health at Stellenbosch University that involved forging difficult conversations regarding the often complex intersection of gender, health and theology. In this process, the discomforting film Skoonheid has been helpful in creating an uncomfortable pedagogical space wherein these students, and the communities they represent, were challenged and inspired to not only lean into discomfort themselves, but also to develop the skills and capacities to go and duplicate these conversations in their contextual settings of influence. Thus, beyond their personal academic formation the hope is that these students will go on to impact their (faith) communities as thought leaders and change agents, by replicating some of the difficult conversations they have engaged in during their time with us. 
The impact of the pedagogical intervention could be far-reaching if we foster in students the willingness to risk setting up these spaces in their communities and landscapes of influence. If we succeed in encouraging students to draw on the reality of their own experience of discomfort and to be bold enough to nudge others towards discomfort and to muster the courage to engage in difficult conversations we might be able to move beyond selfsufficient comfort. Because it indeed seems as if comfort keeps us isolated, safe, separated and protected. Consequently, it may precisely be discomfort, however painful, that is imperative for change.

\section{Bibliography}

Ackermann, Denise M. "Meaning and Power: Some Key Terms in Feminist Liberation Theology." Scriptura 44 (1993): 21.

Berlak, Ann C. "Confrontation and Pedagogy: Cultural Secrets, Trauma, and Emotion in Anti-oppressive Pedagogies." Counterpoints 240 (2004): 123-144.

Boler, Megan. Feeling Power: Emotions and Education. London: Psychology Press, 1999.

Boler, Megan. "Teaching for Hope." Teaching, Learning, and Loving: Reclaiming Passion in Educational Practice (2004): 117-131.

Cho, Sumi; Crenshaw, Kimberlé Williams and McCall, Leslie. "Toward a Field of Intersectionality Studies: Theory, Applications, and Praxis." Signs: Journal of Women in Culture and Society 38/4 (2013): 785-810. https://doi.org/10.1086/669608

Crenshaw, Kimberlé W. "Mapping the Margins: Intersectionality, Identity Politics, and Violence against Women of Color." Stanford Law Review (1991): 1241-1299. https://doi.org/10.2307/1229039

De Waal, Shaun. "Eye of the Beholder." The Mail and Guardian. No Pages. Cited 5 August 2011. Online: https://mg.co.za/article/201 1-08-05-eye-of-the-beholder

Giroux, Henry A. "Breaking into the Movies: Pedagogy and the Politics of Film." JAC (2001): 583-598.

Hermanus, Oliver. "Director's Note." Cinemien. No Pages. Cited 23 February 2012. Online: https://cinemien. nl/downloads/movie/1 1174/6277_persmap.pdf

Jewkes, Rachel. "Intimate Partner Violence: Cause and Prevention." The Lancet 359 (2002): 1615. https://doi.org/10.1016/S0140-6736(02)08357-5

Lammin, Daniel. "Beauty. Not Everything Is as It Seems." Switch. No Pages. Cited 11 June 2012. Online: https://www.maketheswitch.com.au/article/review-beauty-not-everything-is-what-it-seems

Lotz, Deon and Keagen, Charlie. Skoonheid. DVD. Directed by Oliver Hermanus, South Africa: Moonlighting Films, 2011.

Marshall, Lee. "Beauty." Screen Daily. No Pages. Cited 17 May 2011 . Online: https://www.screendaily.com/ beauty/5027731.article

Nadar, Sarojini; Reddy, Sarasvathie; Van der Walt, Charlene; Siwila, Lilian and Gerle, Elisabeth. "Flourishing Guinea Pigs: Exploring Intersectionality and Interdisciplinarity in a Master's." Journal of Gender and Religion in Africa 20/2 Special Issue (2014): 203-230.

Nussbaum, Martha C. Sex and Social Justice. New York: Oxford University Press, 1999.

Reygan, Finn and Francis, Dennis. "Emotions and Pedagogies of Discomfort: Teachers' Responses to Sexual and Gender Diversity in the Free State, South Africa." Education as Change 19/1 (2015): 101-1 19. https://doi.org/10.1080/16823206.2014.943259

Sampson, Lin. "Cries and Whispers." Times Live. No Pages. Cited 14 August 2011 . Online: https://www.times live.co.za/sunday-times/lifestyle/201 1-08-14-cries-and-whispers/

Sonnekus, Theo. "'We're not Faggots!' Masculinity, Homosexuality and the Representation of Afrikaner Men Who Have Sex with Men in the Film Skoonheid and Online." South African Review of Sociology 44/1 (2013): 22-39. https://doi.org/10.1080/21528586.2013.784446

Sonnekus, Theo and Van Eeden, Jeanne. "Visual Representation, Editorial Power, and the Dual 'Othering' of Black Men in the South African Gay Press: The Case of Gay Pages." Communicatio: South African Journal for Communication Theory and Research 35/1 (2009): 81-100. https://doi.org/10.1080/0250 0160902906661 
Steele, Samantha. "Beauty and the Beast within." The Mail and Guardian. No Pages. Cited 15 July 2011. Online: https://mg.co.za/article/201 1-07-15-beauty-and-the-beast-within

United Nations Development Programme. "Millennium Development Goals." No Pages. Cited 31 July 2012. Online: http://www.undp.org/content/undp/en/home/sdgoverview/mdg_goals.html

White, Michael. 1997. Narratives of Therapists' Lives. Adelaide: Dulwich Centre Publications.

Wolgemuth, Jennifer R. and Donohue, Richard. "Toward an Inquiry of Discomfort: Guiding Transformation in 'Emancipatory' Narrative Research." Qualitative Inquiry 12/5 (2006): 1012-1021.

Zembylas, Michalinos. "'Pedagogy of Discomfort' and Its Ethical Implications: The Tensions of Ethical Violence in Social Justice Education." Ethics and Education 10/2 (2015): 163-174.

Zembylas, Michalinos and McGlynn, Claire. "Discomforting Pedagogies: Emotional Tensions, Ethical Dilemmas and Transformative Possibilities." British Educational Research Journal 38/1 (2012): $41-59$. https://doi.org/10.1080/01411926.2010.523779

\section{Endnotes}

1 I dedicate this essay to the life and work of Dr Lilly Phiri, one who was taken from us to soon. Lilly, who was a graduate of the Gender, Religion and Health Master's programme at the University of KwaZuluNatal in 2014 was in the process of developing into a fine scholar. We have lost a conversation partner, a thinker, a colleague and a friend, but above all one who was not too afraid to have difficult conversations and to sit with the discomfort that this necessarily brings.

2 I would like to acknowledge numerous colleagues from various settings and institutions who have been part of this collaborative process of co-constructing teaching and learning spaces that has been developed as part of the MTh Gender and Health journey since 2013.

3 The other academic partners approached by the Church of Sweden in 2012 to join Pilot Program Gender and Health were the Ethiopian Graduate School of Theology (EGST) from Ethiopia, Tumani University Makumira (TUMA) from Tanzania, and the University of KwaZulu-Natal (UKZN) in South Africa.

4 United Nations Development Programme, "Millennium Development Goals," n.p. Cited 31 July 2012. Online: http://www.undp.org/content/undp/en/home/sdgoverview/mdg_goals.html

5 For some earlier reflections on the pedagogical process, see Sarojini Nadar, Sarasvathie Reddy, Charlene van der Walt, Lilian Siwila, and Elisabeth Gerle, "Flourishing Guinea Pigs: Exploring Intersectionality and Interdisciplinarity in a Master's," Journal of Gender and Religion in Africa 20/2 Special Issue (2014): 203-230.

6 The importance given to the contextuality of individual voices grows out of one of the fundamental principles of feminism, namely the central role of women's experience. Ackermann describes the importance of this principle for a feminist hermeneutic as follows: "A feminist hermeneutic, like all hermeneutics, is grounded in experience, and more particularly in women's experience of oppression ... It is essential to acknowledge that experience itself is interpreted and filtered through our cultural matrix, which in turn is formed by the race, class, time and histories of our lives. There is no universal experience for all people or even for all women. Yet, while accepting the particularity of experience as a hermeneutical category, we must acknowledge the universal fact of discrimination against and oppression of women." Denise M. Ackermann, "Meaning and Power: Some Key Terms in Feminist Liberation Theology," Scriptura 44 (1993): 21.

7 I appropriate the term 'constellation of factors' from the work of gender scholar Rachel Jewkes. Jewkes of the Gender and Health Group at the Medical Research Council in Pretoria has developed a theory concerning the causality of intimate partner/gender-based violence. Her model for explaining these causes "presents it as a constellation or web of associated and mediating factors and processes which are centrally influenced by ideas about masculinity and the position of women in a society and ideas about the use of violence." Rachel Jewkes, "Intimate Partner Violence: Cause and Prevention," The Lancet 359 (2002): 1615.

8 For more on intersectionality, see Kimberlé W. Crenshaw, "Mapping the Margins: Intersectionality, Identity Politics, and Violence against Women of Color," Stanford Law Review (1991): 1241-1299. Sumi Cho, Kimberlé Williams Crenshaw and Leslie McCall, "Toward a Field of Intersectionality Studies: Theory, Applications, and Praxis," Signs: Journal of Women in Culture and Society 38/4 (2013): 785-810.

9 For more on the interdisciplinary and transdisciplinary dimensions of the programme and for some earlier reflections on the pedagogical process, see Sarojini Nadar, Sarasvathie Reddy, Charlene van der Walt, Lilian Siwila, and Elisabeth Gerle, "Flourishing Guinea Pigs: Exploring Intersectionality and Interdisciplinarity in a Master's," Journal of Gender and Religion in Africa 20/2 Special Issue (2014): 203-230. 
10 The initial vision of the module could possibly be best summarised in the projected outcomes of the module formulated as follows: At the end of this module the student will: a) Have developed an understanding of the interrelated nature of the three subject areas of Gender, Health and Theology; b) Have knowledge of the range of specific health concerns facing men, women and children as it pertains to issues of gender as well as religion and theology; c) Have an understanding of how health concerns in the local context relate to global health concerns regarding the intersection of Gender, Health and Theology; and d) Be able to consider creative strategies for addressing the specific challenges regarding Gender, Health and Theology in the local community.

11 Deon Lotz and Charlie Keagen, Skoonheid, DVD, Directed by Oliver Hermanus, South Africa: Moonlighting Films, 2011.

12 Theo Sonnekus, "'We're not Faggots!' Masculinity, Homosexuality and the Representation of Afrikaner Men Who Have Sex with Men in the Film Skoonheid and Online," South African Review of Sociology 44/1 (2013): 22-39

13 It is my hope that these tentative remarks will encourage the reader to view the terrifying notion of beauty that Hermanus has constructed in Skoonheid and to join the difficult conversation; but for now, the engagement with the film here will have to suffice.

14 Denise Newman and Keenan Arrison, Shirley Adams, DVD, Directed by Oliver Hermanus, South Africa: DV8 Films, 2009.

15 In a 2011 interview with the Mail and Guardian's Samantha Steele, Hermanus remarks: "We all want something, and invariably it is something beautiful. Beauty ruins you!" The film explores the currency of beauty in the world. The director also tried to explore the belief that beautiful people are better rewarded by society. Hermanus continues: "I wanted to see what happens when a not-beautiful character pursues the beautiful character, and what happens to the not-beautiful character." Samantha Steele, "Beauty and the Beast within," The Mail and Guardian, n.p. Cited 15 July 2011 . Online: https://mg.co.za/article/ 2011 -07-15-beauty-and-the-beast-within

16 Shaun de Waal, "Eye of the Beholder," The Mail and Guardian, n.p. Cited 5 August 2011. Online: https://mg.co.za/article/2011-08-05-eye-of-the-beholder

17 Lin Sampson, "Cries and Whispers," Times Live, n.p. Cited 14 August 2011 . Online: https://www.times live.co.za/sunday-times/lifestyle/2011-08-14-cries-and-whispers/

18 Oliver, Hermanus, "Directors Note," Cinemien, n.p. Cited 23 February 2012. Online: https://cinemien.nl/ downloads/movie/11174/6277_persmap.pdf

19 Daniel Lammin, "Beauty: Not Everything Is as It Seems," Switch, n.p. Cited 11 June 2012. Online: https://www.maketheswitch.com.au/article/review-beauty-not-everything-is-what-it-seems

20 On the choice of Bloemfontein for a setting, Hermanus explains, "It was a city I had preconceived ideas about. It is supposed to be very Afrikaans, very backward, a place where you wouldn't feel good. So when it came to making the film I said immediately, 'Okay, let's go to Bloemfontein.' What is interesting about Bloemfontein is that it has the highest rate of homosexuality in the whole country. There is an element of secrecy. You know, behind the rugby stadium is a gay cruising ground, flash your lights twice, that sort of stuff," Sampson, "Cries and Whispers."

21 For Theo Sonnekus "The act of gay sex is considered more vulgar if it is with someone from another race, because it transgresses not one, but two of the central taboos that shape and direct conventional Afrikaner masculinity. In other words, the colorved boy's Otherness affronts these men by confronting them with a dual dose of deviance, which is emblematic of black gay in terms of being twice removed from the 'standards' of white, Afrikaner patriarchy: they are to gay and to black." Theo Sonnekus, "We're not Faggots!' Masculinity, Homosexuality and the Representation of Afrikaner Men Who Have Sex with Men in the Film Skoonheid and Online," South African Review of Sociology 44/1 (2013): 24. For more in this regard, see also Theo Sonnekus and Jeanne van Eeden, "Visual Representation, Editorial Power, and the Dual 'Othering' of Black Men in the South African Gay Press: The Case of Gay Pages," Communicatio: South African Journal for Communication Theory and Research 35/1 (2009): 81-100.

22 Lee Marshall, "Beauty," Screen Daily, n.p. Cited 17 May 2011 . Online: https://www.screendaily.com/ beauty/5027731.article

23 Marshall, "Beauty."

24 Moffie is a derogatory Afrikaans slang word for a gay man, best translated as queer or fag in the negative sense of the word.

25 Sonnekus remarks: "With Skoonheid, the representation of sex lends itself to Hermanus' exploration of heterosexually identified men who enjoy the physicality of gay sex, but in no way transcends their already established heteronormative identities. His idea for the film, after all, develop [sic] from discovery of newspaper classifieds for 'sex clubs' that facilitate the meeting of married, 'straight' men with other married, 'straight' men." 
26 Hermanus, "Director's Note."

27 Martha C. Nussbaum, Sex and Social Justice (New York: Oxford University Press, 1999), 183.

28 My experience resonates with that of Henry Giroux who states that, "Film provided me with a pedagogical tool for offering students alternative views of the world. Of course, film not only challenged print culture as the only viable source of knowledge; it was an attractive cultural text for students because it was not entirely contaminated by the logic of formal schooling." Henry A. Giroux, "Breaking into the Movies: Pedagogy and the Politics of Film," JAC (2001): 585.

29 Steele, "Beauty and the Beast."

30 lbid.

31 Ibid

32 One of the key writing assignments that forms part of the assessment for the Core Module Gender and Health is a three-page writing reflection on the film. Although some of the other writing reflections that form part of the assessment entail peer interaction, the Skoonheid reflection is personal in nature and directed confidentially to me as the coordinator. I received consent from all the students referenced in this essay and due to the private nature of their reflections, the students will not be identified by name.

33 One student remarks in this regard: "The Skoonheid film perfectly portrays many things that are real to the lives of men and in particular gay men in the society ... I personally believe the movie is a real portrayal of how life is lived among many individuals. We often say or behave this way among our friends, families and communities, but deep inside we have certain things that we are even ashamed that others must know [sic] due to fear of not living to the standard that the society, culture, religion and other institutions requires from us. We all suffer this. But the question is: Who then has power to define morality in societies, and by what standard, and are they real to the world?"

34 Megan Boler, Feeling Power: Emotions and Education (London: Psychology Press, 1999).

35 Ann C. Berlak, "Confrontation and Pedagogy: Cultural Secrets, Trauma, and Emotion in Anti-oppressive Pedagogies," Counterpoints 240 (2004): 123-144.

36 Michalinos Zembylas, "'Pedagogy of Discomfort' and Its Ethical Implications: The Tensions of Ethical Violence in Social Justice Education," Ethics and Education 10/2 (2015): 163-174.

37 Michalinos Zembylas and Claire McGlynn, "Discomforting Pedagogies: Emotional Tensions, Ethical Dilemmas and Transformative Possibilities," British Educational Research Journal 38/1 (2012): 41-59.

38 Zembylas, "Pedagogy of Discomfort," 166.

39 Megan Boler, "Teaching for Hope," Teaching, Learning, and Loving: Reclaiming Passion in Educational Practice (2004): 117-131. Cf. also Jennifer Wolgemuth and Richard Donohue who remark in this regard: "The aim of an inquiry of discomfort is to identify and promote an intentional and conscious shift from dualistic, categorical, and entrenched positionality to a more ambiguous engagement with social reality." Jennifer R. Wolgemuth and Richard Donohue, "Toward an Inquiry of Discomfort: Guiding Transformation in 'Emancipatory' Narrative Research," Qualitative Inquiry 12/5 (2006): 1012-1021.

40 When reflecting on the role of emotions in pedagogical settings of transformation Zembylas and McGlynn argue that, "Any understanding of discomforting pedagogies is thus inextricably linked to analysing the pivotal role of emotions in disrupting hegemonic perceptions and feelings. It has been argued, therefore, that if a major purpose of teaching is to unsettle taken-for-granted views and emotions, then some discomfort is not only unavoidable but may also be necessary." Zembylas and McGlynn, "Discomforting Pedagogies," 43.

41 Finn Reygan and Dennis Francis, "Emotions and Pedagogies of Discomfort: Teachers' Responses to Sexual and Gender Diversity in the Free State, South Africa," Education as Change 19/1 (2015): 101-119.

42 Michael White, Narratives of Therapists' Lives (Adelaide: Dulwich Centre Publications, 1997), 141.

43 White, Narratives of Therapists' Lives, 141.

44 For an important reflection in this regard, see Zembylas, "Pedagogy of Discomfort," 163-174.

$45 \mathrm{lbid}, 164$.

$46 \mathrm{lbid}, 166$. 


\section{CO-CREATING TRANSFORMATIVE SPACES THROUGH DIALOGUE \\ Inclusive and Affirming Ministries' Partnership with the Faculty of Theology, Stellenbosch University}

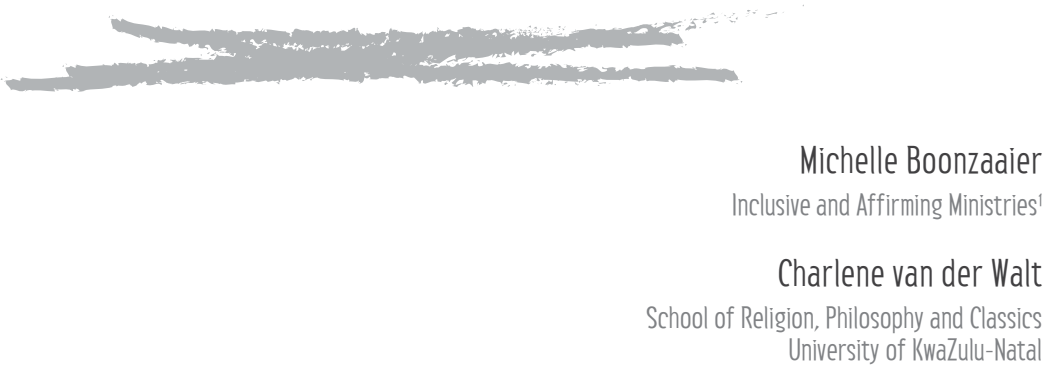

\section{Introduction}

In this essay, we offer a praxis reflection on the content and implementation of the Sexual Diversity workshop that Inclusive and Affirming Ministry (IAM) ${ }^{2}$ annually presents to the Masters of Divinity (MDIV) students at the Faculty of Theology, Stellenbosch University. ${ }^{3}$

Over the last decade, this workshop has become a supportive space where students can engage in discussions about sexual diversity and also find ways to use dialogue to engage with congregations when they are in full-time ministry in the Dutch Reformed Church (DRC). ${ }^{4}$ A significant portion of the workshop is aimed at developing nuanced vocabulary and finding ways to talk about sexuality and sexual diversity. The workshop further aims to be a pastorally supportive space for students as they prepare for full-time ministry, offering these prospective ministers resources to deal with the complexity of pastoral support to LGBTIQA $+{ }^{5}$ people and their families, as well as creative dialogue skills when engaging conversations pertaining to diversity in complex conservative faith communities. Furthermore, students are made aware that in their role as religious leaders who are expected to guide church councils and congregation members in their dealing with the complexity of sexual diversity in local congregations, the necessary support and resources are available to them.

Inviting DRC LGBTIQA+ clergy and members into this space to share their experiences with students in itself becomes a transformative practice and "point(s) to social activity" 
that shapes people's lives for the better. ${ }^{6}$ The workshop space aims to be an inclusive and transformative space that allows students to engage with their own stories, the story of the DRC and of LGBTIQA + people in the DRC. In that space, students are also able to engage with the decisions of the DRC on homosexuality over the past 30 years. Participants are invited to encounter homosexual clergy in the DRC and listen to their stories of exclusion, integrating sexuality and spirituality, and the impact that the DRC's decisions have had on their lives over time.

In this essay, we offer some background to IAM's engagement with the MDIV programme. We further reflect on the content of the workshop and how students are supported in developing vocabulary to talk about diversity in general and about sexual diversity in particular. The workshop has evolved and developed over time and this essay reflects on its development as a form of pedagogical praxis reflection. We argue that the theoretical resources explored and developed in the MTh Gender and Health programme have had a significant impact on the workshop in that the resources have informed the theoretical underpinning of the workshop and offered critical resources for ongoing praxis reflection.? The mutual exchange, enhancement and inspiration between IAM and the MTh Gender and Health programme through staff interaction, collaborative projects and transformative discussion are but one example of how the boundaries between academia and contextual impact zones have become blurred and permeated. It is fair to say that not only IAM has benefited from this exchange, but that the teaching praxis of the MTh Gender and Health has been informed and enhanced by the contextual knowledge and insight offered by IAM as a contextual organisation, dealing with concrete realities at the intersection of Gender, Health and Theology. The annual IAM sexual diversity workshop with the MDIV class is a remarkable example of how the interaction between academia and community partners can be mutually beneficial and can collectively have a bigger footprint than the individual projects. ${ }^{8}$

\section{Background and Development of the Workshop}

Inclusive and Affirming Ministries' participation at Stellenbosch University (SU) began in 2006 as an information session to the Master of Divinity students. Due to the impact that these information sessions had on students and lecturers, a decision was made to increase the scope from being an information session on homosexuality to a two-day training workshop, which deals with the complexity of LGBTIQA+ individuals and their dealings with sexuality, spirituality and the church.

Since its inception, the workshop has developed into a space where presenters and students address the complexities of the intersections between race, gender, class and disability, amongst others. ${ }^{9}$ The current two-day workshop, which started out as an information 
session, fits into a week-long module of the MDIV course that places a strong focus on Reconciliation and Justice.

Initially, when these sessions were launched, Proponent Judith Kotze and Reverend Pieter Oberholzer were the facilitators. They shared with students their individual journeys with homosexuality, first as theology students at Stellenbosch University and later as clergy. They shared their journeys of integrating their sexuality and spirituality within the space of the DRC, first as members and later as religious leaders who were denied ordination in the church that they grew up in.

What was particularly useful about these initial information sessions was that students were informed by two homosexual Christians who have journeyed with their faith and have faced the challenges of integrating their sexuality and spirituality. Both Pieter and Judith have journeyed with being white Afrikaners in South Africa and members of the DRC and shared the complexity of this identity that they live with.

It is important to note that whereas the aim of the information session was originally to create awareness around homosexuality, the workshop has subsequently also been expanded to assist students as upcoming religious leaders to develop vocabulary for dealing with issues of diversity. ${ }^{10}$ A shared vocabulary assists in breaking down barriers, while also addressing real or perceived power imbalances. It enables students to engage in conversations about diversity thereby providing them with the necessary tools to become transformative leaders in the church and in the public sphere.

While the workshop is designed primarily to provide students with practical skills and resources to engage with diversity, IAM has also acknowledged the importance of enhancing the theoretical component of the workshop. The theoretical foundation for the IAM's sexual diversity workshop has been informed, expanded and enhanced by the organic interaction between IAM and the MTh Gender and Health programme at Stellenbosch University. ${ }^{11}$ The academic component of the workshop encourages students to engage with the writings of feminist theologians, body theologians and queer theologians that are included in the reading list that students study before the workshop. In order to enhance theoretical reflection and interaction, students are also encouraged to complete a compulsory written assignment ${ }^{12}$ based on a reading list provided prior to the workshop.

The workshop guidelines invite students to engage in a variety of ways with issues pertaining to diversity for two days. The aims of the workshop, which are stated in the course outline, are as follows:

- To create a space for critical theoretical reflection on the complexity and intersection issues regarding gender and sexuality; ${ }^{13}$

- To empower church leaders to engage creatively with diversity pertaining to gender and sexuality; ${ }^{14}$ 
- To assist church leaders in the development of safe spaces for dialogue rather than debate by drawing on the contextual strategies developed by IAM; ${ }^{15}$

- To explain and practically guide students through the inner workings of Contextual Bible Study as a potential tool for facilitating creative dialogue; and

- To expose students to IAM as conversation partners and to the various resources that have been developed by IAM in the course of the last 21 years.

After completing the module, students should be able to:

- Understand something of the complexity of issues relating to gender and sexuality;

- Reflect on situations of oppression/marginalisation and dehumanisation in an intersectional manner;

- Understand the complexity of issues relating to sexuality within mainline churches in the South African context;

- Understand the value of IAM's approach using dialogue; and

- See the potential of the Contextual Bible reading space as one that facilitates creative dialogue.

Moving from these contextual and developmental aspects of the workshop, in the second half of the essay, we offer some examples of the development of the workshop in the form of a pedagogical praxis reflection. Although this is not an exhaustive list, we highlight a number of examples of how the form and content of the workshop have been informed, enhanced or enriched by the organic collaboration between IAM and the MTh Gender and Health programme at Stellenbosch University and how these have found expression in the IAM sexual diversity workshop.

\section{All Experiences Matter}

During the workshop, students engage with the reality that in the past, not all experiences were seen as relevant to the study of theology and sometimes even continue to be discounted today. By means of the reading list and class discussions, students engage with the feminist liberation understanding that experience, especially the experience of women, stands at the heart of theology. ${ }^{16}$ Patriarchal, heteronormative and heterosexist language is interrogated and LGBTIQA+ voices are a central part of class discussions.

Students are exposed to South African feminist voices like Denise Ackermann who claim that feminist theologians have found it necessary when engaging in research to probe "analyses terms, definitions and perspectives critically in order to clarify their meaning when applying them to women's experience" ${ }^{17}$ The same is true when reflecting on the experiences of LGBTIQA+ individuals. Language is of critical importance when talking about the exclusion and inclusion of memories, experiences and histories of marginalised 
people. Ackermann further observes that what it means to "have faith in a sexist world" is different for women than for men. The same is true for LGBTIQA+ people who live in a heteronormative and homophobic world. For this reason, it is important to reflect on language and the way terms and concepts are used in talking, especially about theology.

In order to enter into any significant dialogue, it is important to have communal and mutually comprehensible language. As is true for feminists as well, there is no one common "homogenous" language or one common experience for LGBTIQA+ people. Thus, it is even more important that language becomes part of a greater conversation, which includes as many diverse voices as possible in the dialogue that takes place in the workshop, as well as in faith communities. ${ }^{18}$

In a response to gender-based violence, Elize Morkel emphasises the importance of using language to break down discourses that have shaped our "individual consciousness". ${ }^{19}$ In the same way that language constructs "economic, social and political discourses" that inform violence and the violation of women, language also constructs discourses that inform heteronormative and homophobic practices. "Finding language", according to Morkel is also a way of undoing the destructive discourses that violate people and lead to silencing practices. ${ }^{20}$ Finding language is a way to be present in an embodied way and join the very people who uphold the destructive discourses. The co-constructed space created in the MDIV workshop becomes an area where language can be discovered and tested in order to develop more inclusive and affirming spaces in faith communities.

During the workshop, students encounter the "fragmentation of theology" for theology becomes "messy as it becomes the stuff of real lives". ${ }^{21}$ When more people are included in the conversation, the dialogue process becomes a painful and messy one, because it is no longer only an individual or single-group experience that decides on the normative scheme. Theology no longer offers easy answers and "eternal absolutes", but rather the discomfort of experience as it becomes "a changing and expanding thing". 22

When we value the experiences of all people, especially those whose body experience has been disregarded and undervalued, we directly address power. The power of "prearranged categories", naming people and stigmatising people, no longer lies with one group. ${ }^{23}$ The power now "lies among the people who now strive for justice". ${ }^{24}$ Students are exposed to the experience of deconstructing power during the workshop. The team of facilitators try to make this possible through the diversity of the team and of their views. Even though presenters differ in age, race, sexual orientation and class, they try to engage with one another and with the students in a way that creates a space - albeit, sometimes messy and risky - that accommodates and emulates living with all of the tension and complexity of diversity. 
Experience is the basis of sexual diversity and the dialogue that brings about a sexual theology. This comes about when we take seriously the experiences of women, LGBTIQA+ people, teenagers and people with disability. James Nelson states that this is when we will "know the difference between sexual theology and the more typical theology of sexuality". ${ }^{25}$ A theology of or about sexuality tends to argue in a one-directional way. It asks what Scripture and tradition say about sexuality and how it ought to be expressed; it asks what the church says, what religious leaders say and what people in authority say. Nelson argues that this is not enough; liberation theologies rather seek to prioritise human experiences. These theologies inquire how human sexual beings read Scripture and interpret tradition and how they live "the meanings of the gospel". This act of interpretation is a movement in two directions - from experience, we move towards and interpret Scripture and tradition. From Scripture and tradition, we interpret human experience. Experiences that "nurture wholeness" and "seek out theologies of hope and resurrection" are the ones in which people are reincarnated into their bodies and no longer lead lives of "dualism and disincarnation".

In a process to give concrete form on the insights highlighted above, students are introduced to two methods that incorporate the multiplicity of experience as highlighted above, namely the Binary Box and Contextual Bible Reading. In both cases, participatory pedagogical experiences are co-constructed by students and facilitators, which accentuate on the one hand the importance of a personal contextual position informed by experience, and on the other hand the ability to make space for the gift of other experiences or positions. Before sharing some insights regarding the theoretical underpinning and the collaborative construction of these participatory pedagogical experiences, first, we would like to reflect on the construction of a safe and constructive teaching and learning space that would allow students to risk their vulnerability to enter into these exercises.

\section{Invitation to a Liturgical Space of Risk and Sharing of Embodied Experiences}

In order to accentuate the importance of a personal contextual position, as well as the ability to make space for the gift of other experiences or positions, the insistence on the sharing of stories, memories and experience from participants' own embodied and contextual realties has been an integral part of the workshop..$^{27}$

As an introduction to the stories of LGBTIQA + clergy in the DRC, the TED talk by Chimamanda Adichi is screened in class. ${ }^{28}$ Adichi reflects on the importance of "thickening" the stories of people's lives and on the hybridity of identity to illustrate that no person is only one thing. Every person is more than his or her position in life. The person's relational situatedness is also fundamentally more than his or her gender identity.

In the same way, the church has various stories about homosexuality. Therefore, students are given a broad outline of the DRC's journey with homosexuality. They are encouraged 
to understand and discuss the broader context in which the DRC's decisions were made and the various stories of their denomination, as well as how the history and context of South Africa have influenced the development of the DRC's identity and relationship with LGBTIQA+ people and the decisions made by various general and regional synods. Students are invited and challenged to listen to stories of LGBTIQA+ clergy and members whose realities have been directly impacted by decisions made by the DRC. When LGBTIQA+ people are included in the workshop space, the question of what a "new DRC" looks like in a post-apartheid South Africa arises.

For several years, Inclusive and Affirming Ministries has defined our training by a number of distinct characteristics. Our training space is a space of dialogue and not debate. Our training space is a space of safety for participants to engage freely with each other. Our training is a transformative space that invites faith communities to move towards becoming inclusive and affirming spaces.

Recently, we have begun to interrogate the use of the concept "safe space" in our training on Human Sexuality and Diversity. We question whether it is at all possible for spaces in which we seek transformation through deep dialogue to be "safe spaces". We also question whether it is possible for people who differ in their theological positions to be "safe" in a space where there is conversation on diversity and difference by diverse voices. Does any new learning, transformation and shift in position take place in a safe place? Do we not need to take a risk when entering a space of deep dialogue?

Subsequently, in 2017 we invited workshop participants to experiment with us in our training space on Human Sexuality and Diversity. The aim of the invitation has been to transform the workshop space into a liturgical space that invites people into a space of safety in which they dare to take risks as they enter into dialogue and listen. The space of safety is created by lighting a candle in the middle of the room, excluding tables and note taking from the space in order for us to engage in dialogue with our bodies "from (our) place". 29

The safety of the space relies on participants and skilled facilitators taking responsibility to co-create space by sharing their experiences of diversity and sexuality; holding a space in which tension, confusion and paradox can be accepted as gifts and lived with. The first risk that participants are invited into is getting out of their heads and into their bodies.

On the first day of the MDIV workshop, the storylines of various denominations including the DRC are highlighted. As the day progresses, other stories that are traditionally not heard are included. When the stories and experiences of LGBTIQA+ people are introduced, students are encouraged to share their own stories and experiences. At this point in the workshop, the room setup is important to telling stories from a personal position. Students are invited to position the chair on which they will be seated at any place in the room that reflects their position. Students are free to seat themselves at the centre of the room, along 
its edges, with their backs to the centre of the room, close to an exit, et cetera. The place that each individual chooses is the place from which they tell of their experiences and also the place from which they respond to the experiences of others to which they are listening.

The two questions that all participants are invited to reflect on when sharing a story and experience are:

- When was the first time that you realised that you were attracted to someone?

- How did the church help you to discover/explore your sexuality?

As important as the room setup is for speaking from participants' own place, so too is the inclusion of liturgical symbols and setting up the space as a liturgical space. Two basic Christian symbols are brought into the space - light ${ }^{30}$ and an empty cross ${ }^{31}$ - in order to thicken the story and our theological reflection, which are situated within a story with deep symbolic origins. Everyone in the space offers different meanings to symbols in their own way. At the end of the workshop the symbols of bread and wine are introduced as a way of sharing in each other's experiences and as a reminder that we continue to journey together in an embodied way.

IAM's Wheel of Change in Figure 1 is used as a tool to invite people into a process of dialogue from any position in which they find themselves. Each of the positions on the wheel of change can be a starting point to engage in dialogue. The positions can be described as:

- Diversity awareness (open minds): In this position a participant indicates willingness to listen and learn; to find new language and words to engage in dialogue that leads to a better understanding of diversity.

- Dialogue in safe spaces (open hearts): Participants are prepared to engage actively in dialogue and co-creating safe spaces in which diverse voices, stories and experiences are heard.

- Empowering people: Participants join the process from a position where they have already been empowered through language and listening to diverse experiences.

- Change agents: Participants have already been empowered and are actively participating in transformative programmes and projects that lead to inclusive and affirming faith communities.

- Inclusive and affirming faith communities: Participants celebrate diversity.

Participants are invited to position themselves on the wheel, to engage in dialogue from this space and to reflect on any shifts in position throughout the workshop. Throughout the process of dialogue, participants are invited to position and reposition themselves and reflect on their repositioning based on three questions: What am I feeling? What am I thinking? How have I repositioned myself? Speaking about repositioning and how the repositioning came about is a valuable part of engaging in dialogue with other participants. The reflection and repositioning become a creative tool for inclusion and affirmation of diversity in faith communities. 


\section{Moving Towards Inclusion and the Celebration of Diversity}

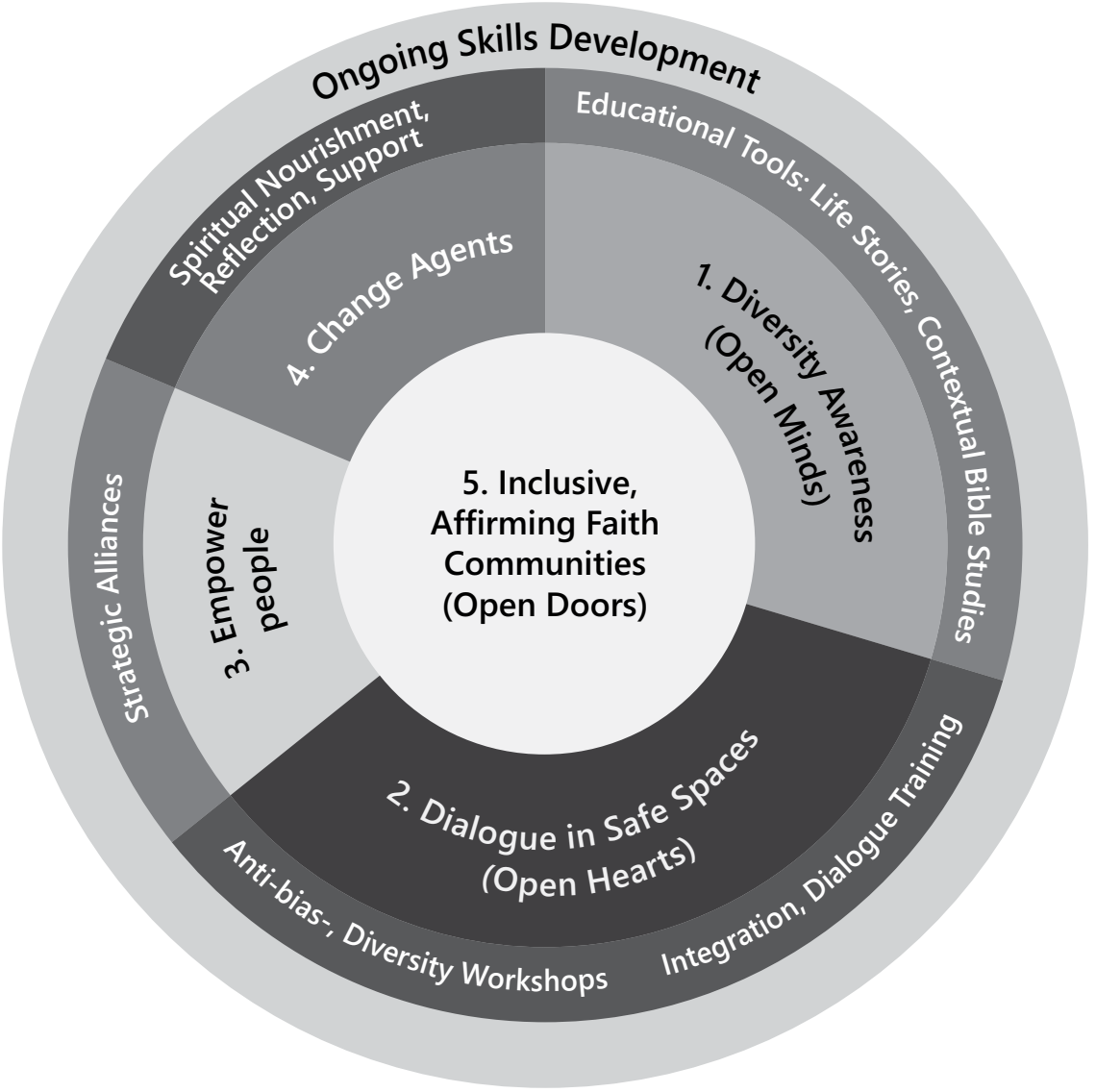

Figure 1 IAM's Wheel of Change

\section{Participatory Pedagogical Experiences}

As already mentioned, in these co-constructed safe liturgical spaces, students are introduced to two methods that incorporate the multiplicity of experience, namely the Binary Box and Contextual Bible Reading. In the next section, we briefly highlight the theoretical underpinning and the collaborative construction of these participatory pedagogical experiences.

\section{Binary Box ${ }^{32}$}

The Binary Box tool that we introduced to talk about human sexuality ${ }^{33}$ enhances a broader conversation on sex, gender ${ }^{34}$ and gender identity, ${ }^{35}$ sexual orientation and sexual practice. 
The aim of the exercise in which students are invited to dynamically participate is to unpack complex terminology related to gender, sex and sexuality. The Binary Box diagram is drawn on a sheet of paper in the class and interactively completed by facilitators and students. Besides allowing for creative conversation on a topic that is often regarded as taboo, the exercise also achieves a politically important outcome. After unpacking all the terms and the various discourses to which the terms belong, students are asked to place themselves on the diagram. ${ }^{36}$ The importance of situating oneself within the diagram is that it undermines the general assumption that discussion of sexuality is somehow always discussion about sexual minorities. The Binary Box shifts the parameters of the conversation and highlights the importance and necessity of inclusive discussions pertaining to sex, sexuality and gender within faith communities.

\begin{tabular}{|c|c|}
\hline $\begin{array}{c}\text { SEX } \\
(\text { Biology) } \\
\text { - Man } \\
\text { - Woman } \\
\text { - Intersex }\end{array}$ & $\begin{array}{l}\text { GENDER IDENTITY } \\
\text { (Social Construct) } \\
\text { - Masculine } \\
\text { - Feminine } \\
\text { - Androgyny } \\
\text { - Transgender } \\
\text { - Transsexual } \\
\text { - Trans-man } \\
\text { - Trans-woman }\end{array}$ \\
\hline $\begin{array}{l}\text { SEXUAL ORIENTATION } \\
\text { (Attraction/love) } \\
\text { - Lesbian } \\
\text { - Gay } \\
\text { - Bisexual } \\
\text { - Asexual } \\
\text { - Pansexual } \\
\text { - Heterosexual } \\
\text { - Queer }\end{array}$ & $\begin{array}{l}\text { SEXUAL PRACTICE } \\
\text { - Penetrative sex as an example } \\
\text { - Oral sex as an example }\end{array}$ \\
\hline
\end{tabular}

Figure 2 The Binary Box

When introducing the concept of 'binary', we introduce the idea that when talking about sex and sexuality there are people who are not able to find themselves inside the box. Sex refers to "the division of species into either male or female" and has a specific emphasis on reproductive functions. ${ }^{39}$ 'Intersex' is a general term used for a variety of embodied realities where a person is born with a reproductive or sexual anatomy that does not seem to fit the "typical definitions of female or male". 40 The complexity of the conversation about biological sex is challenged by bio-medical science and research, which prove/show that there are not only two sexes, but more sexes, that is, some people are intersex. Intersex people have 
ambiguous genitalia across a spectrum and the introduction of intersex realities into the conversation about biological sex has proven to be very helpful in disrupting the binary notion of sex.

When starting a conversation on sexuality in faith communities, one of the first things to note is that for a long time some people have been excluded from the conversation because of the experience of their bodies, which is different from that of those who hold the dominant conversation. We must note that in most faith communities no conversation on sexuality is taking place.

When talking about sexuality we refer to the complexity of human bodies that has a very recent history and does not date back to pre-modern times. Since experts do not agree on what the term 'sexuality' means, the conversation in the workshop encourages students to grapple with this complexity of diverse voices that are included in their own faith communities. ${ }^{41}$

In this regard, Alfred Kinsey and his associates were the first people to place homosexuality on a continuum in a 1948 study. ${ }^{42}$ The authors challenged the assumption that most people are either homosexual or heterosexual, arguing that most people are not "either/ or" but rather "both/and”. It is clear from Nelson's study that "our orientations are given, not freely chosen", possibly a "combination of genetic and hormonal factors, together with environmental and learning factors" - nature and nurture. Furthermore, "our sexual orientations are established rather early in life, most likely somewhere between the ages of two and five, and thereafter are largely resistant to dramatic changes". 43

Sexual attraction forms a part of the "wide range" of the definition of sexuality. It has long been accepted that some people move beyond the binaries of traditional heterosexual attraction between a man and a woman. Lesbian women are attracted to women, homosexual men are attracted to men and bisexual people are attracted to both men and women, and whereas some of them choose to remain celibate, others are faithful to one person and others lead promiscuous lives. ${ }^{44}$

By allowing for dynamic conversations informed by theoretical insights as developed in the MTh Gender and Health programme, IAM has successfully developed a practical pedagogical space that allows for the interrogation of dominant ideas about sex, sexuality and gender and for the development of more nuanced discussions pertaining to this intersection within faith communities.

\section{Contextual Bible Study and Intercultural Bible Reading}

The Bible plays a "prominent and important role" in "the negotiation of ethical issues". This is not anything new and is not limited to the South African landscape when engaging with 
issues of gender, sexuality and faith. It is evident in conversations in both the church and the public spaces that are occupied by people for whom the Bible is a primary source of ethical reflection. ${ }^{45}$

In order to open up new and dynamic spaces in the often beleaguered landscape of Bible engagement at the intersection of gender, sexuality and faith, IAM employs tools and insights developed within related fields of Contextual Bible Study and Intercultural Bible reading. In terms of Contextual Bible Study, IAM draws on the rich legacy of work that has been done under the leadership of Prof. Gerald O. West by the Ujamaa Centre for Community Development and Research based at the University of KwaZulu-Natal.

Contextual reflections by "ordinary readers" and insisting on the epistemological privilege of the poor as described by Gerald West and others have a long and powerful history. ${ }^{46}$ Readers always bring their context to the text through the questions and concerns that inform their interpretation. Our contexts, therefore, "always shape our reading practice".77 Contextual Bible Study provides readers "access to unfamiliar texts" that are historically "suppressed by their church traditions", but have to remain part of the reading and interpretive world of biblical scholars. It also provides access to "unfamiliar literary units" in texts that are otherwise familiar. Lastly, it "provides ways of reading familiar texts in unfamiliar ways".48

Beyond the important first step of a Contextual Bible Reading, IAM also encourages students to risk the encounter with the "other" by incorporating insights as developed within the praxis of Intercultural Bible Reading. Intercultural Bible Reading is an important space for dialogue to take place and for people to find new ways of talking about ethical issues. ${ }^{49}$ The method encourages students to enter into the process of reading and reflecting on Bible stories with others, including those ideologically removed from them. It creates the space for alternative understandings, positions and insights to develop. Rather than remaining closed, exclusivist and isolated in its engagement with the biblical text, the Intercultural Bible Reading process imagines an alternative - an alternative where we no longer refuse to listen to those most affected, most marginalised and most silenced, but where we dare to risk the possibility, the recognition of the humanity of the other, and in the process restore the mystery of life in the rich diversity of vulnerable communion.

For an Intercultural Bible Reading process to be authentic, the starting point has to be an in-depth embodied contextual engagement with the biblical text in order to bring to the encounter with "the other" a unique reading of the text that is specifically local. On the other hand, the intercultural dimension encourages local contextual readers to consider the possibility of a diversity of interpretations and the imperative for critical self-reflection, as well as the possibility of a change in interpretation or position. ${ }^{50}$ 


\section{Conclusion}

This essay has offered a pedagogical praxis reflection on the process of developing the IAM MDIV sexual diversity workshop at the Faculty of Theology at Stellenbosch University. The IAM MDIV sexual diversity workshop outlined in this essay has been developed in order to offer students a space to engage critically with their own stories of sexuality and diversity in light of the complex history and context of the DRC in South Africa today. This workshop has been vital in order to help students reflect on what an inclusive church looks like, and to cultivate the necessary language and skills in order to discuss diversity in their respective faith communities. Specific attention is given to sexual diversity, with students being encouraged to continue the journey to find fresh ways of being a relevant church on the African continent.

The IAM MDIV sexual diversity workshop at the Faculty of Theology, Stellenbosch University grew from a morning information session to an extended co-constructed space for collective reflection on the complex intersection of gender, sexuality and religion. The transformative value of the workshop has been recognised, and the Faculty of Theology has agreed to extend and reposition it in the 2017 curriculum. The workshop will now run for three days and shift into a larger teaching block that deals with diversity and community. The new positioning of the workshop will stimulate greater acceptance as it will include participation from various departments of the entire Faculty of Theology. ${ }^{51}$ The expansion of focus demonstrates the value of how previously neglected aspects of more intensive social engagement and reflection across theological disciplines is included, and also points to the added benefit that ensues when academic and contextual partners enter into a dynamic collaboration.

\section{Bibliography}

Ackermann, Denise M. "Meaning and Power: Some Key Terms in Feminist Liberation Theology." Scriptura 44/2 (1993): 19-33.

Ackermann, Denise M. Tamar's Cry: Re-reading an Ancient Text in the Midst of an HIV/AIDS Pandemic. CIIR, 2002.

Ackermann, Denise M. "From Mere Existence to Tenacious Endurance: Stigma, HIV/AIDS and a Feminist Theology of Praxis." Pages 221-242 in African Women, Religion, and Health: Essays in Honor of Mercy Amba Ewudiziwa Oduyoyo. Edited by Isabel A. Phiri and Sarojini Nadar. Eugene, OR: Wipf and Stock Publishers, 2012.

Adiche, Chimamanda. "The Danger of a Single Story." Cited 21 January 2013. Online: https://www.ted.com/ talks/chimamanda_adichie_the_danger_of_a_single_story

De Gruchy, John W. "The Contest for Reformed Identity in South Africa during the Church Struggle against Apartheid." Pages 26-36 in Reformed Churches in South Africa and the Struggle for Justice: Remembering 1960-1990. Edited by Mary-Anne Plaatjies-van Huffel and Robert Vosloo. Stellenbosch: AFRICAN SUN MeDIA, 2013. https://doi.org/10.5952/54-3-4-384

Gunda, Masiiwa R. Report on Methodology, Stumbling Blocks and Stepping Stones. Based on a Literature Study for the Period 2009-2014. (2015). No Pages. Cited 21 January 2016. Online: https://hivos.org/reportmethodology-challenges-opportunities-work-inclusive-affirming-ministries-iam-2009-2014 
Isherwood, Lisa and Stuart, Elizabeth. Introducing Body Theology. Sheffield: Sheffield Academic Press, 1998.

Kessler, Rainer. "From Bipolar to Multipolar Understanding. Pages 452-459 in Through the Eyes of Another: Intercultural Reading of the Bible. Edited by Hans De Wit, Louis Jonker, Marlene Kool and Daniel Schipani. Elkhart, IN: Institute of Mennonite Studies, 2004.

Morkel, Elize. "Responses to Gender Injustice." Pages 125-146 in Living with Dignity: African Perspectives on Gender Equality. Edited by Elna Mouton, Gertrude Kapuma, Len Hansen and Thomas Togom. Stellenbosch: AFRICAN SUN MeDIA, 2015.

Nelson, James B. Body Theology. Lovisville, KY: Westminster/John Knox Press, 1992.

Okure, Teresa. "Reading from This Place: Some Prospects and Problems." Pages 52-69 in Reading From This Place. Edited by Fernando Segovia and Mary Ann Tolbert. Minneapolis, MN: Fortress Press, 1995.

Thatcher, Adrien. God, Sex, and Gender: An Introduction. Chichester, West Sussex: Wiley Blackwell, 2011. https://doi.org/10.1002/9781444396386

Theron, P. F. (Flip). "From Moral Authority to Insignificant Minority. The Precarious State of the Dutch Reformed Church in a Post-apartheid South Africa." Dutch Reformed Theological Journal/Nederduitse Gereformeerde Teologiese Tydskrif 48/1-2 (2007): 233-242.

Van der Walt, Charlene. "Is 'Being Right' More Important than 'Being Together'? Intercultural Bible Reading in the Dutch Reformed Church, South Africa." Pages 125-137 in Christianity and Controversies over Homosexuality in Contemporary Africa. Edited by Ezra Chitando and Adriaan van Klinken. New York: Routledge, 2016. https://doi.org/10.4324/9781315571928-9

West, Gerald O. Biblical Hermeneutics of Liberation Modes of Reading the Bible in the South African Context. 2nd ed. Maryknoll, NY and Pietermaritzburg: Orbis Books and Cluster Publications, 1991.

West, Gerald O., ed. Reading Other-wise: Socially Engaged Biblical Scholars Reading with their Local Communities. Atlanta, GA: Society of Biblical Literature, 2007.

\section{Endnotes}

1 Michelle Boonzaaier is a graduate of the MTh Gender, Health and Theology programme of the Faculty of Theology, Stellenbosch University. This essay is based on her MTh research assignment, "Creating Transformative Spaces through Dialogue: Partnership between Inclusive and Affirming Ministries and the Faculty of Theology at The University of Stellenbosch" (Stellenbosch University, 2017).

2 Inclusive and Affirming Ministries (IAM) was founded in January 1995 by Pieter Oberholzer, a gay minister in the Dutch Reformed Church who had been forced to move to Holland because of his sexual orientation. IAM works in South Africa and other southern African countries and works towards influencing religious leaders and communities to become more open to, inclusive of and affirming LGBTI people in a process of dialogue and active engagement through workshops, dialogue events, training and resource development and dissemination. The various modes of engagements have been extended over time to include dialogue on gender, race, class as well as sexuality. Masiiwa R. Gunda, "Report on Methodology, Stumbling Blocks and Stepping Stones. Based on a Literature Study for the Period 2009-2014," n.p. Cited 21 January 2015. Online: https://hivos.org/report-methodology-challenges-opportunities-workinclusive-affirming-ministries-iam-2009-2014

3 The Master of Divinity programme is geared towards developing religious leaders to be engaged citizens, as well as leaders in local congregations. The programme includes all theological discipline groups (Old and New Testament, Practical Theology and Missiology, as well as Systematic Theology and Ecclesiology). Information received from the Faculty of Theology website, n.p. Cited 9 January 2017. Online: http://www.sun.ac.za/english/faculty/theology/Pages/Postgraduate-Programmes.aspx

4 The MDIV class includes students from other denominations besides DRC students. However, due to the current complexity of the issue within the DRC and in light of the history of the denomination's engagement or lack of engagement with the issue of sexual diversity, we choose to locate and focus our current discussion of the case study in this space of the DRC.

5 LGBTIQA+ is short for Lesbian, Gay, Bisexual, Transsexual, Intersex, Queer, Asexual and Gendernonconforming.

6 Denise, M. Ackermann. "From Mere Existence to Tenacious Endurance. Stigma, HIV/AIDS and a Feminist Theology of Praxis," in African Women, Religion, and Health: Essays in Honor of Mercy Amba Ewudiziwa Oduyoyo, ed. Isabel A. Phiri and Sarojini Nadar (Eugene, OR: Wipf and Stock Publishers, 2012), 221 -242.

7 The MTh Gender and Health programme started in 2012 when representatives of the Church of Sweden approached the Faculty of Theology at Stellenbosch University in conjunction with other African academic 
partners to start a new research focus in the existing MTh programme that would explore the intersection of Gender, Health and Theology within our local context. The impetus for this initial request came, because the Church of Sweden in collaboration with the Swedish Government Development Agency (SIDA) was eager to find ways of addressing two of the United Nations' Millennium Goals, namely the reduction of child mortality and the improvement of maternal health.

8 Here, we use the MDIV class at Stellenbosch University as a case study example, but the workshop has also taken place at the College of the Transfiguration in Grahamstown, Seth Moketimi Methodist Seminary in Pietermaritzburg and the Moravian Seminary in Cape Town and it will be rolled out to various other academic institutions and seminaries over the next few years.

9 The diversity of concrete lived experiences explored in terms of content is also reflected in the diversity in the composition of the workshop facilitators.

10 The overarching rationale behind workshops. such as the IAM sexual diversity workshop in the MDIV curriculum. is to invite students to engage with and have a contextual embodied understanding of the full range of diversity that they will have to deal with in ministry, in church settings and in the public sphere, particularly in a post-Apartheid South Africa where over time communities and churches have begun to reflect the reality of a diversity, which includes amongst others racial, political, economic, social, cultural and sexual diversity. In order for the learning experience to assist students to operate as leaders beyond the church and also in a diverse society, the course includes workshops that enjoin contextual organisations like IAM to share practical field experiences of dealing with sexual diversity.

11 Numerous IAM staff members have completed the MTh Gender and Health programme at Stellenbosch University and Dr Charlene van der Walt who coordinated the MTh Gender and Health programme that took off in 2013 was a part-time researcher with IAM from 2012 until 2016. This overlapping of roles and responsibilities has been mutually beneficial to IAM as an organisation and the pedagogical praxis of the MTh Gender and Health and it finds unique expression in the MDIV Sexual Diversity workshop.

12 The writing assignment from the workshop completed by consulting the prescribed readings consists of the following components. First, students are encouraged to develop a personally formulated definition of gender. This task encourages students to start the process of developing much needed vocabulary pertaining to the intersection of gender, sexuality and faith. Second and continuing the same objective as in the first component, students are asked to unpack and describe the terms taken up in the LGBTIQA+ collective. Third, in order to situate the sexual diversity discussion within a particular faith context, students are asked to write a paragraph of a personal reflection on their Church denomination's engagement with the issue of homosexuality. Lastly, in order to place the discussion in a broader context, students are encouraged to identify an example from contemporary media that speaks to the gender of sexuality, that is, a newspaper article/blog/opinion piece.

13 Even though the workshop started out as a reflection on homosexuality, it has grown to include other issues of diversity.

14 A specific spotlight is placed on the impact and implication of religion and theology on formulating ideas and beliefs around gender and power. Sexuality is a subject that is not often discussed in the context of churches and it is introduced as a topic through which students can engage with people who are already working in the field of sexual diversity.

15 An extensive discussion of what it means to enter into dialogue with people who have different experiences of their bodies in the DRC is encouraged. Students are encouraged as church leaders to develop skills that will help them to create a space for dialogue on various contentious subjects within their congregations.

16 Lisa Isherwood and Elizabeth Stuart, Introducing Body Theology, Vol. 2 (Sheffield: Sheffield Academic Press), 1998.

17 Denise, M. Ackermann, "Meaning and Power: Some Key Terms in Feminist Liberation Theology," Scriptura 44/2 (1993): 19-33.

18 lbid, 31.

19 Elize Morkel, "Responses to Gender Injustice," in Living with Dignity: African Perspectives on Gender Equality, ed. Elna Mouton, Gertrude Kapuma, Len Hansen and Thomas Togom (Stellenbosch: AFRICAN SUN MeDIA, 2015), 125-146.

20 Ibid, 139.

21 Isherwood and Stuart, Introducing Body Theology, 39.

22 lbid.

23 lbid.

24 Ibid.

25 James B. Nelson, Body Theology (Lovisville, KY: Westminster/John Knox Press, 1992). 
26 Ibid, 70

27 Here we take our cue from Denise Ackermann's view that, "Telling stories is intrinsic to claiming one's identity and in the process finding impulses for hope ... Narrative has a further function. Apart from claiming identity and naming the evil, narrative has a sense-making function. The very act of telling the story is an act of making sense of an often incomprehensible situation, of a suffering and chaotic world in which people wrestle with understanding and in so doing seek to experience relief." Denise Ackermann, Tamar's Cry: Re-reading an Ancient Text in the Midst of an HIV/AIDS Pandemic. CIIR, 2002.

28 Chimamanda Adiche is a Nigerian novelist. In this TED talk, she reflects on the danger of single stories and the power of "thickening" the stories of individual people. The 'thickening' process of stories implies the addition of detail, contradiction, nuance, context and complexity to the often one-dimensional perceptions held about others or the narratives that gives shape to their lives. Chimamanda Adiche, "The Danger of a Single Story." Cited 21 January 2013. Online: https://www.ted.com/talks/chimamanda _adichie_the_danger_of_a_single_story

29 Here we take our cue from the important work of Teresa Okure. For more in this regard, see Teresa Okure "Reading from This Place: Some Problems and Prospects," Reading from This Place - Social Location and Biblical Interpretation in Global Perspective (1995): 52-66.

30 Reference is made to John 1 where light becomes the presence of Christ - the embodiment of Christ incarnate who comes to pitch his tent amongst people as the embodied presence of God. Participants are invited to join in a continued incarnation.

31 The empty cross is regarded as a symbol of our stories intersecting at the cross of a suffering Christ. The empty cross is a symbol where diverse bodies intersect, not only in suffering but also in re-recreation by a resurrected Christ.

32 The Binary Box is introduced to Inclusive and Affirming Ministries by Rainbow Identity Association in Botswana. See: http://www.riabotswana.org

33 We refer to sexuality as the deep relational bond between people, which could include erotic desire and intimacy but is not limited to these. Sexuality is a lot more than what people do with their genitals. It is the way that people live in the world with their bodies - gendered bodies. It encompasses the entire human experience - socially, biologically and culturally - and this experience in turn lays the foundation for "our moral agency". The Binary Box is a way of finding language to talk about sexuality and about sexual theology. Nelson, Body Theology, 45. Isherwood and Stuart, Introducing Body Theology, 78.

34 Gender as a social construct affects every part of our personal and social lives. Identifying as a man or woman is reflected by how we dress, how we walk, talk, eat, drink, sit, stand; what jobs we do; how we socialise and who we socialise with; how people relate to us and how we relate to other people. Institutions are also gendered and gendering of individuals takes place in institutions. The human body experience is a gendered one - the way we are in the world socially, culturally and politically; the way in which our institutions are structured is gendered. Adrien Thatcher, God, Sex, and Gender: An Introduction (Chichester, West Sussex: Wiley Blackwell, 2011), 18-20. Nelson, Body Theology, 45.

35 The term 'transgender', or 'transsexual', refers to people who were born with "typically male or female anatomies", but who have a deep knowledge that they have been born into "the "wrong body'". 'Transgender' is an umbrella term, and people who self-identify as transgender may take hormones to become male or female, or may elect to have gender affirming surgery. Yet, other people may choose to dress in a gender affirming way by wearing clothing that are associated with a sex that their bodies are not. 'Transgender' as a political term is a troubling one that problematises the clearly set boundaries of male and female, masculine and feminine. Thatcher, God, Sex, and Gender, 12.

36 The Binary Box also referred to as the human sexuality grid or gender grid has undergone a number of changes as IAM's participation as facilitators in workshops is critiqued, challenged and shifted. Initially, the gender grid consisted of five boxes - the four existing boxes and a central box that reflected transgender people. Over time and with critique from participants, the five boxes have changed into four with transgender people being included in the "gender identity" box. The change reflects a better understanding that transgender is a gender identity.

37 The general view is that there are two sexes, male and female. A male has a penis, scrotum and a particular set of predominant hormones. Females have vaginas and internal sex organs and develop enlarged breasts as they enter adulthood. Females also have different dominant hormones from males.

38 Sexual practice refers to various ways in which people - men and women of various sexual orientations give embodied expression to their sexual attraction and sexuality.

39 Thatcher, God, Sex, and Gender, 4.

40 lbid, 12.

$41 \mathrm{lbid}, 3-5$. 
42 Nelson, Body Theology, 66

43 Ibid, 67.

44 Thatcher, God, Sex, and Gender, 2-5, 252.

45 Charlene van der Walt, "Is 'Being Right' More Important than 'Being Together'? Intercultural Bible Reading in the Dutch Reformed Church, South Africa," in Christianity and Controversies over Homosexuality in Contemporary Africa, ed. Ezra Chitando and Adriaan van Klinken (New York: Routledge, 2016), 124-237.

46 On the so-called ordinary readers, Gerald West remarks that, "Part of the substantive claim I am making in differentiating between the scholar and nonscholar/ordinary reader is that there is a difference in the way each of these sectors read biblical texts. This difference is significant, and recognition of this difference can lead to creative and socially transformative collaboration between different sets of interpretive resources these different sectors bring to a collaborative reading project. So, in the general sense I am focusing on the kind of interpretive training different sectors have received. The ordinary reader has been 'trained' by his or her primary (for example, the family) and secondary (for example, the church and school) communities, whereas the scholarly reader has been trained by a tertiary community, the academy." Cf. Gerald O. West, Reading Other-wise: Socially Engaged Biblical Scholars Reading with Their Local Communities, SBL Series No. 62 (Atlanta, GA: Society of Biblical Literature, 2007), 2. See also: Gerald O. West, Biblical Hermeneutics of Liberation Modes of Reading the Bible in the South African Context, Second ed. (Maryknoll, NY and Pietermaritzburg: Orbis Books and Cluster Publications, 1991).

47 Gerald $\bigcirc$. West, "Contextual Bible Reading: A South African Case Study," Analecta Bruxellensia 11 (2006): $131-148$.

48 Ibid, 145.

49 Van der Walt, "Is 'Being Right'," 132.

50 During the workshop, students are exposed to the theoretical and contextual works of Reiner Kessler, Gerald $O$. West and Charlene van der Walt and to practical Bible studies developed by the Ujamaa Centre. Students are introduced to these resources, which enable them to engage in a practical reading of the text together and expose them to ways in which texts read in a contextual and intercultural manner can be transformative and can shape our ethical reflections. Rainer Kessler, "From Bipolar to Multipolar Understanding," in Through the Eyes of Another: Intercultural Reading of the Bible, ed. Hans De Wit, Louis Jonker, Marlene Kool and Daniel Schipani (Elkhart, IN: Institute of Mennonite Studies, 2004), 452-459.

51 The IAM Sexual Diversity Workshop has been reframed in the 2017 curriculum to form part of a larger teaching block in collaboration with Congregational Studies and Community Analysis in African Contexts (Prof. Nadine Bowers du Toit), Gender, Culture and the Bible in the Life of the Church (Prof. Juliana Claassens), and Child and Youth Culture (Prof. Anita Cloete). 


\section{REIMAGINING SIN? \\ Nurturing Youth Spiritualities for Social Justice}

Selina Palm

Unit for Religion and Development Research

Faculty of Theology

Stellenbosch University

\section{Introduction}

Sin is not a black and white book of things that you can and cannot do; it's more like a set of values that underpin our worldview. It's less of a tickbox and more about systems and structures.

(Dan, RUC, coloured male youth aged 20)

Sin is arguably one of the oldest theological words in the book. In the light of the practical task of cultivating change agents within society, it may seem strange to focus on such an abstract, dogmatic theme. What has sin got to do with practical change? However, theologian Ted Peters suggests that at the root of the symbol of sin is a "pervasive sense that things are not the way they ought to be" ${ }^{1}$ leading to a sense of estrangement that can fuel both despair and aggression. I suggest that re-engaging with sin can enable a thinking through of how we might take shared responsibility for structural and social change. Recent empirical research in South Africa demonstrates the presence of high levels of unquestioned belief in God with $75 \%$ attending church at least once a month and $77 \%$ seeing Jesus as the "solution to all the world's problems". ${ }^{2}$ If our theological terms are to be reimagined, they also need to be translated into concrete practical approaches at local level.

This essay explores this possibility by drawing on my experience within a local church congregation Rondebosch United Church (RUC) in Cape Town. I first highlight some of the frameworks being used to reimagine sin within the wider church ethos and then indicate its possibilities in conversation with Angela (not real name) aged 18, a long-term youth attender at RUC. Her responses and those of other youth arguably give credence to the claim that creatively reimagining sin may help local churches to cultivate change agents around contemporary intersectional oppressions, including those around gender and sexuality. 
Thus, this essay explores how change agents could be cultivated in local churches by reimagining $\sin$ in ways which engage young people in making social connections between the symbol of sin and social injustices in their present realities. It introduces intersectional frameworks by Jürgen Moltmann and Iris Marion Young as the underpinnings for an approach enacted at Rondebosch United Church (RUC), Cape Town, where the author is a youth leader. The essay places this into conversation with interviews with youth members from RUC who form part of a wider research study into youth formation by the Unit for Religion and Development Research. ${ }^{3}$

\section{Why Reimagine Sin?}

North American theologian Ted Peters ${ }^{4}$ notes that the topic of sin can be difficult to discuss. The reason is that many people, including himself, harbour anger about their childhood religious training in relation to sin and its constant admonishments about God's law and our sin in ways that focus attention on how terrible we should feel about ourselves as sinners. He sees the home, as well as church congregations and church schools, as influential places for children, because this problematic approach where strictness becomes identified with godliness are re-inscribed in those spaces.

Peters' analysis resonates with my own youth journey in churches and schools where I found that many of the ways sin was articulated failed to resonate with my experiences of the world. I was reminded either in the traditional words of the Anglican prayer book that I was an imperfect "miserable offender" in the eyes of God, or by an evangelical tradition that the things that I personally had done were so bad that Jesus had to die for them to satisfy the anger of God. Neither of these resonated clearly with what I saw as I learned more about the world in the 1990s with its complex problems of war, disease, famine, ecological harm, racism, sexism and economic exploitation. In fact, these sin narratives often created a sense of peripheral powerlessness where "God" seemed to have a mysterious plan and Christians were just to pray and leave it to "him". When, years later, as a trained theologian I was invited to develop sessions for RUC's church confirmation class, I saw a similar disconnect for many youth today. Songs about being "washed in the blood of Jesus" had often left their mark and sin was typically still connected to a personal piety of middle-class good behaviour. Either youth were told about sin in individualistic ways that punished doubts, disobedience and pride, or churches avoided sin-talk to dwell triumphantly on the positive side of life in ways that silenced youth's questions and experiences of life's brokenness. Few equipped them to grapple constructively with concrete social issues around and within them. RUC aimed to navigate an alternative - to engage with sin-talk in a "liberating-prophetic" way ${ }^{5}$ which fitted with its theological ethos as part of youth identity formation. In this context, gender and sexuality issues emerged from below. 
South African black theologian Simon Maimela ${ }^{6}$ also critiques this emphasis by much traditional theology on sin merely as disobedience against God's holy will as anthropologically limited. He notes that it often has little effect on the wider sinful situation of social oppression and dehumanisation in which most people find themselves. Salvation becomes abstract and fails to lead to concrete transformation in violent people, their interpersonal relations and in the unjust structures in the socio-political sphere. He suggests that this abstraction negates the reality of the incarnation where God is actively on the side of people who suffer to show that all domination, oppression and dehumanisation of any humans contradicts divine intentions to overcome sin and recreate human community. ${ }^{7}$

Black, liberation, African and, in particular, feminist theologians who often write from the underbelly of history have noted that in much of Western Christianity, a static view of history and social institutions has developed in which social structures such as class, race, gender and sexuality were seen as being ordained by God and, therefore, fixed and unchangeable. Their provocative counter-claim is that Christian confession of faith in God must always be linked to and integrated with the confession of justice within society. This, according to Maimela, "redefines the concept of sin" not as largely a personal matter between the sinner and God, but as a social, community concept - a condition of alienation resulting from broken relationships between God and humanity and between human beings themselves. It reconnects the biblical stories of Genesis 3 and 4 where the fundamental sin of alienation is the cause of all situations of injustice, oppression and the will to dominate. Numerous feminist scholars ${ }^{8}$ have noted the danger of a single abstract definition of the sin of pride or self-love, which they suggest is often androcentric, tailored to the sins of the (male) oppressor rather than to female experiences. Reformed theologian Jürgen Moltmann ${ }^{9}$ also insists that this abstract understanding of sin has created a false separation of justification and justice-creation, which needs urgent reconnection, especially in Reformed congregations. It is this social reconnection, which underpins RUC's shaping of sin through a liberational-relational lens. This connects the vertical love of God with the horizontal love of all other people and the earth to insist that sin-talk always has both personal and structural dimensions. RUC's decades of history as a struggle church against apartheid ${ }^{10}$ has informed this social embodiment of sin, which now needs to be taken forward in conversation with a new generation.

\section{RUC's Core Ethos - Enlarging Circles of Dignity}

RUC's ethos is guided by an inclusive vision of Enlarging Circles of Dignity - pointing to a grassroots theology that takes concrete contexts seriously. It draws on principles of roundtable worship and the idea of a God of ialogue. According to its minister, Robert Steiner, this, brings together the theological dimensions of life with the socio-political, connecting spirituality and social justice. Circles of dignity modelled around the roundtable in worship are intended to 
extend out into everyday lives and ministries, both communal and individual. These circles are ones of inclusivity, solidarity and compassion. Services seek to rehearse and enact these in ways that have ripple effects into wider communities where the body of Christ has a particular concern for the weakest in society, those left out, marginalised or exploited. ${ }^{11}$

RUC members are encouraged to challenge all forms of status quo that perpetuate injustices, drawing and passing on their earlier roots as an anti-apartheid struggle church and nurturing an olive theology that makes connection between God, others and the earth. The emphasis here is on moving beyond apathy to embrace a theology of being "upstanders" and not "bystanders" in relation to social justice. ${ }^{12}$ RUC's ethos draws energy from Desmond Tutu's image of a centripetal embrace that can reverse the awful centrifugal force of alienation, brokenness, division, hostility and disharmony. Here the figure of Jesus on the cross with outflung arms clasps everyone and everything in a cosmic embrace so that all, everyone, everything belongs. Tutu points to the core value of inclusion where,

no-one is an outsider, all are insiders, all belong. There are no aliens, all belong in the one family, God's family, the human family ... we are different so we can know of our need for one another ... no-one is ultimately self-sufficient. ${ }^{13}$

My reimagining of sin as a youth leader at RUC for over ten years was situated within this ethos, seeking ways for sin discussions to be contextual, dialogical and to take seriously RUC youth as active participants with their own lived experiences and circles of influence. They are not merely passive recipients of pre-existing and unchallengeable church dogmas. I wanted to pay attention to the current social context of South Africa and the legacy of historical church complicity with, and silence on, apartheid as just one challenge to many inherited church dogmas in the light of current human rights and social justice concerns. RUC is situated close to the University of Cape Town where student protests have also shaped the last few years. Many of our congregants were caught up in different ways in this lived experience with its focus on multiple oppressions of gender, sexuality, race, class and coloniality. The question of intersecting oppressions became an experiential reality that many of our youth had to engage with. Making sense of this together benefited from the use of a social framework of vicious circles. Likewise, our Presbyterian and Congregational denominations were going through a consultation process around LGBTIQ inclusion in which RUC, its Minister and myself played a leadership and advocacy role in its 2016 Human Sexuality Report. This became a key issue that emerged from youth who argued that how sin was framed in churches needed reimagining.

RUC's youth group itself also holds long memories as a specific place where young change agents had been cultivated into embodied resistance in the past. Important South African struggle theologians such as John de Gruchy, Denise Ackermann and Jim Cochrane and their children engaged with or passed through RUC. The declaration by some South African theologians that apartheid was a sin and blasphemy against God added a significant 
contribution to social change. That declaration differed radically from the stance of other churches, which either theologically legitimated the social sins of apartheid, or took a pietistic approach that enabled the divorce of responsibilities to God from that of suffering neighbours, and even perpetuated a passive acceptance of systems of domination as ordained by God. ${ }^{14}$ In the post-apartheid dispensation, RUC seeks to take its confessing, contextual Kairos trajectory into new spaces. Gender and sexuality have arguably become a new site of struggle for the emerging youth generation which play out over embedded fractures of race, culture and social location. Just as a few decades earlier RUC cultivated youth change agents through its explicit theological view of apartheid as a sin, it is called to continue this today in new intersectional ways. Sin required reimagining for apartheid to be named sin and challenged theologically. Therefore, ongoing reimagining is also arguably needed in the light of new complex social justice struggles if churches are to become allies for social transformation and if their theological words are to have resonance for new generations. Sexuality and gender have often been deeply entangled in problematic forms of church sin-talk. Can sin be reframed in relation to sexuality and gender for church youth in a way that supports current social justice struggles? Initial findings from a 2017 research project on youth formation at RUC offer some insights into the usefulness of a creative framework on sin and it is to these we now turn.

\section{An Intersectional Framework for Sin}

To develop tools for reimagining sin within RUC, I turned to German Reformed theologian Jürgen Moltmann. His early concept of "vicious circles of death" names five interrelated circles from which both oppressor and oppressed in their complexities are trapped and in need of practical liberation. ${ }^{15}$ He terms these "Constantinian patterns" of domination, privilege and marginalisation in which we are all embedded. This model reshapes sin away from something private between individuals and God to a relational understanding of sin as deformed relationships within history with self, others and nature, re-thinking virtuous living as embodied, liberated relationality that recognises the "Other" ${ }^{16}$ Moltmann sees sin as a form of "misplaced identity" that can involve both dominance and hiding. ${ }^{17} \mathrm{He}$ argues:

The oppression of human beings by human beings is sin. It is a crime against life (for life means love your neighbour as yourself). It is a destruction of the love of God (for the one who does not love his or her brother or sister whom they have seen, cannot love God whom they have not). The oppression of other humans is a perversion of love because it wounds, offends and destroys the image of God on earth. ${ }^{18}$

Moltmann insists that oppression always has two sides - for the victim who is dehumanised and for the oppressor who acts inhumanely - creating a society polarised in multiple ways such as South Africa. His five circles have both psychological and socio-political dimensions, which he claims need to be addressed for liberating praxis to emerge and 
for human identity to be grounded in ways of understanding human dignity that liberate others rather than trap them in self-justifications. He sets out five reciprocal "liberations" to shift paradigms of freedom from dominating power-over to power-with and within to become human in new community. ${ }^{19}$ Moltmann is concerned that a Reformation focus on the justification of sinners through Christ has often led to a one-sided emphasis on the perpetrators in Western Christianity and has forgotten about their victims. He sees this as a "great gap" in many theologies of justification and its disconnection from justice-creation as "a righteousness that puts things right". ${ }^{20}$ As a result, he has consistently demonstrated a concrete theological concern for justice for the victims who suffer many forms of violence.

Martin Luther's notion of being a "free lord" can mutate in practice into dominating modes of "ruling the world" and Moltmann offers a reminder that Christ's passion is first and foremost solidarity with the victims of sin and their fate. The great judgement in Matthew 25 is the identification of Godself with the hungry, naked and imprisoned and the judgement of the perpetrator in the face of what has been done to them.

Moltmann's five circles framework is illustrated in Figure 1 using a diagram designed by the author of this essay and based on Moltmann's 1974 book.

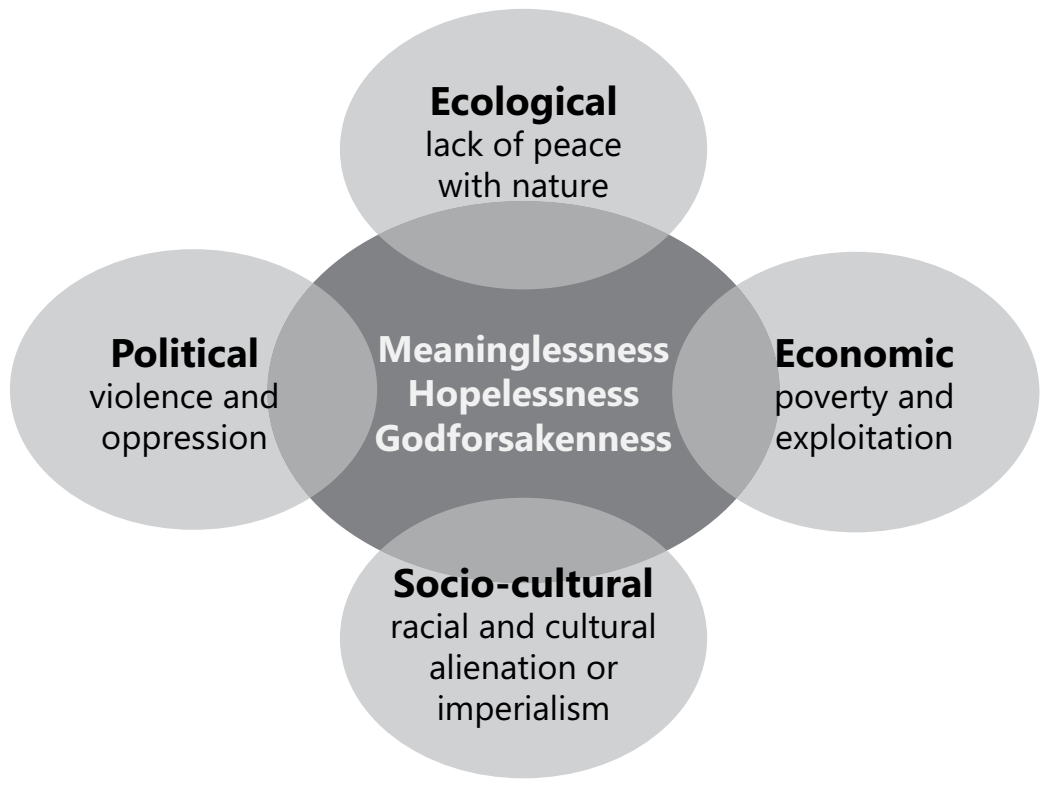

FIgURE 1 Moltmann's five circles framework

Moltmann is wary of conceptualising sin and salvation in "abstract" ways that do not acknowledge concrete differences between victims and perpetrators in different contexts. He insists that the inhumanity of sin can only be concretised within history. ${ }^{21}$ The "humanisation of the human"22 takes place from within these socially embedded circles 
with a need for a "solidarity Christology" for victims as the reverse of a "reconciliation Christology" for oppressors in relation to how sin is understood. ${ }^{23}$ This resonates well in South Africa with its post-apartheid reconciliation discourse. A theology of the liberation of the oppressor enables more people to see themselves as accomplices of the forces that oppress and the systems which do their sinning for them. This requires painful insights into unjust structures perpetuated by privilege if they are to become "liberated oppressors".

I expanded this "five circles" framework in my work at RUC by aligning it with the "fivefaces of oppression" model of feminist critical social theorist Iris Marion Young, who, like Moltmann, locates injustice in concrete contexts of domination and oppression. She points to a "possibility-directed model" that nurtures imagination for alternative visions of social relations that go beyond both communitarian/individual and care/justice binaries. ${ }^{25}$ Young's "five faces" of oppression are exploitation, marginalisation, powerlessness, violence and cultural imperialism, and correspond well in a more contemporary way to Moltmann's older vicious circles. Like Moltmann, she also emphasises the need for a social ontology of humans and explicit engagement with the relational and structural realities of power in a "social connection" model of responsibility. ${ }^{26}$ She maintains that we all still inhabit a concrete world where some bodies matter more than others and that real change involves learning to see and acknowledge this within our concrete contexts if education or well-meaning charity are not to reproduce, but to challenge these social relations of domination. For Young, abstract ideas of impartial justice can close down the lived realities of our concrete plurality. Cultivating imagination helps nurture sympathy and a sense of concrete connection and responsibility to diverse others. ${ }^{27}$ She illustrates this with the sweatshop industry to acknowledge the connection to all involved in various chains such as economic, ecological, political and social - if we are not to participate in causing harm. ${ }^{28}$ Young emphasises solidarity "ongoingly forged and renewed" as the virtue required for responsible citizenship. ${ }^{29}$ These two models informed my reimagining of sin in RUC's youth work.

\section{Listening to RUC Youth Voices}

At RUC, you are accepted. It does not matter if you have a criminal record. That is just what I have noticed about RUC and its grown on [sic] me ... we are all humans and we make mistakes. I know at other churches you will get judged for those mistakes ... you will be outcast or labelled. Labels are a huge problem for me, especially coming from a place in Africa with a history of labelling black people themselves and then being violent against them.

(Atiemo, RUC black male youth aged 19)

The second part of this essay turns to some of RUC's youth voices, modelling the emphasis placed by Moltmann and Young on listening to the experiences and voices of those involved by seeing them as active participants, subjects and co-creators, not as passive receptacles for prior knowledge. In a research project about forming youth for spiritualities of social justice at the Unit for Religion and Development Research at Stellenbosch University, 
the author carried out interviews with long-term youth attenders at RUC to see how they had experienced this approach. I draw primarily here on an interview carried out in early 2017 with 18-year-old Angela, a long-term white female youth attender at RUC, as well as some reinforcing interviews by Dan, a 20-year-old coloured male and Atiemo, a 19-year-old black male (not real names). All were asked to reflect on their experience of RUC's ethos in relation to sin, spirituality, social justice and its role in their formation. Angela compares this with her parallel experience over four years in a more conservative church denomination (Church A).

\section{Inclusion and Acceptance of Diversity}

When asked to describe the theological ethos of RUC, Angela's first word was "inclusivity". She pointed to an "olive" theology articulated within confirmation classes that holds together concern for people (brown) and of the earth (green) with connection to God. The Enlarging Circles of Dignity theme made her increasingly mindful of discriminatory patterns that "often left some out". She noted that the emphasis was on "finding God through being your most authentic self not by seeing yourself as bad or by trying to be selfless". She contrasted this with what she termed a scripted perfect Christian "cookie cut-out" ideal to which she was to conform that she had seen and experienced as prevalent in many other South African churches and religious schools. She immediately pointed to gender and sexuality as a key differentiator in her theological experience at RUC and gave two examples.

Angela described a youth group session that she regularly attended (at Church A) on "how to dress like a godly woman" aged fifteen. She describes it as "a list of things not to do and rules to observe" and that it was directly commented on that "her shorts were too short". She noted that this session was very focused on the needs of the young men in the room "so that you don't tempt them" and that it made her feel "really awkward ... when no-one challenged what was said, it was just accepted". She began to hide her body as a result of attending this session. She compared this with her RUC experience where "we spoke about gender issues and the need to 'call out' gender norms". She pointed to other practices that she observed at RUC that made this real for her. First, was the changing of the pronouns used for "God" and "mankind" in the songs and prayers of the ordinary services. Second, the church was "non-judgemental on dress ... I could wear what I liked ... bare feet, shorts etc. and I could stop worrying if this is too short or too revealing." This was important for her as a young woman. She recalled seeing other youth "come out" or "explore their sexuality" openly within this Christian space and that this was seen as acceptable. These were "big things" as they challenged the accepted social norms she had consistently encountered in other Christian spaces and at her (religious) school. 
This theme of body/gender and diverse sexuality acceptance as opposed to labelling and judging also came up for other RUC youth interviewed as an important feature for them:

I feel like a large part of RUC's theology is based on a social justice model ... its stance against apartheid was based on a theology of social injustice and that also shapes its openness in its attitudes to LGBT community ... To be precise about [what I like about] the ethos, it would be the openness to the LGBT community. The justification for it is very powerful around its interpretation of the Bible with a willingness to continuously review. It's not just black and white.

(Dan, coloured male youth aged 20)

Some churches want perfection in religion - they remove the human error or the humanity from religion. We become like robots, you should not do this thing, you have to be prayed for and go and fast, you have to be purified or cleansed. When I went to 'Church school A' as a child, I was taught that our bodies don't get to go to heaven because they are too dirty, they are just vessels for the soul, they are not pure but unholy - this makes us feel bad about our bodies.

(Atiemo, black male youth aged 19)

\section{Sin as Social Intersections}

When Angela was asked specifically about how sin had been communicated to her, she contrasted her RUC experience with Church A. This theme emerged for her in about Grade 8 or 9 at the age of 14. She noted that Church A had a strong focus on the cross and that the concept of sin was attached to purity and the idea of needing to be "washed clean". She recalled that this was a real concern for her and that she was coming home every day and re-counting her sins seeing sin as "little traps that needed to be repented of". Church A gave her a set of red beads that symbolised all her sins and small crosses to remind her that only the cross can take them away. Increasingly she described dissatisfaction with this framing and said that eventually she rejected this idea entirely:

I actually made a 180-degree turn and felt that sin was just a crazy concept used to oppress people ... But through attending confirmation class at RUC over a two-year period (age 14 to 16) I was able to even out a bit and rethink sin not as individual small actions but as wider social injustices.

(Angela, RUC white female youth aged 18)

She recalled the specific youth exercise at RUC that explored the multiple vicious circles of sin. Each youth had to situate themselves imaginatively as part of each circle and engage with a concrete scenario together that made connections to others in the web and highlighted oppression in action. For example, the economic circle began with someone at home sipping a cup of tea. Each young person had to think about the connections between that simple act and other human beings and take on a character in the web of interdependence. For example, one person was the child in Uganda forced to leave school to pick tea leaves, another was the truck driver who transports the tea and maybe spends all his time on the road. One was the water provider company who decides who gets priority for the supply of water to boil in a kettle in your home and one was the tree in the Ugandan 
forest that was cut down to make way for the tea plantation. Youth were invited to create new characters and add their stories to them. For example, one chose to be an endangered frog species which lived on the tree. Each person held a coloured thread that represented the connection to another and each time that connection became harmful, the threads were twisted. This builds on the sweatshop exercise described by Young. Angela found it to be an approach that "asks you to think for yourself. It is not just a list of sins". She also admits that at the time,

I found this exercise actually morally confusing ... we are all tangled up in these threads ... which way is up? A simple choice like buying a chocolate bar can have consequences for others and it reinforced how connected everything is ... I was able to start to recognise discriminatory patterns in society ... I heard the word intersectionality for the first time at RUC youth group and became more aware of language, how it can exclude and what we even think of as being 'natural'.

(Angela, white female youth aged 18)

\section{Pedagogical Tools for Intersectional Awareness}

Without prompting, Angela also recalled other activities that had reinforced this alternative understanding of sin for her over her youth years at RUC. First was a stand-on-the-line activity that depicted what each person felt on various moral issues. This enabled her to relativise her perspective and see there was not just one way to think. She said, "I loved the activity of placing everyone on a spectrum with regard to how we perceive moral issues especially in relation to gender and sexuality, I saw how different we all are." She termed it a "non-conforming tool" which opened up discussion spaces at RUC on divisive topics like abortion.

Second, she recalled a youth activity in which they used four boxes entitled "It's my culture", "The Bible says so", "My experience shows me" and "It's just reasonable/natural". This tool draws implicitly on the theological quadrilateral to communicate some different ways of justifying opinions on hot topic issues in the church such as homosexuality. She noted that, "It equipped me to target people who use those excuses ... I had tools ... I could step into the psyche of someone who would discriminate and argue from there." Third, she remembered a debate in confirmation class on the Garden of Eden Bible story entitled "To eat the apple?" She said:

We were asked to look at both sides and really engage with the question about if disobeying is always a bad thing ... maybe knowledge is not sinful. We looked at who gets demonised in the story and how it would feel to be the snake or Eve for example. Some of us said it's OK for humans to 'dominate' the world and others disagreed.

Lastly, she pointed to an eco-communion liturgical activity done outside in the park, which increased her realisation that things are broken between us, the earth and others and the need to confess this. Table fellowship is not just about God, but also about communing 
with each other and with nature, which is also brought to the communion table. This focus on eco-theology at RUC, which is a SAFCEI eco-congregation, ${ }^{30}$ was very important for her. She noted that it helped her to make a shift from the idea of being "protectors over" to being "part of" the earth where we care for our caregiver. An activity looking at how Old Testament prophets listened to the pain around them before speaking out also helped her to think differently about her voice:

We are not superior but are part of it. If we want to become eco-prophets we have to listen and connect first. I have an affinity for nature and the activities we did at youth helped me to feel at one with the earth, rooted and grounded. Not a set of 'rules' but an 'experience'.

When asked if theology matters for understanding social justice, Angela made explicit links between the two. She suggested that this RUC formation became a way for her to find her sense of spirituality through social justice issues and not merely disconnected from them.

I felt very proud of RUC's ethos, its different values and ways of thinking and I was glad not to be the only one. I had a sense of shared journey. This hit home once when a Christian friend said 'you aren't a real Christian'. She did not see our church as real Christianity with the right rules.

She concluded that RUC goes to the heart of the matter to ask,

How do we live as better human beings not as policed human beings ... Sin can become 'superficial' in Christian circles just concerned with petty sins ... reimagining the language is really lovely. I always hated the stereotypical bible language of 'we are all born sinners, all men are fallen' ... but maybe we are all sinners not because we are falling short of the 'perfection of Christ' but because we are not addressing social or ecological justice.

\section{Cultivating Change Agents}

We are responsible to make change where you think it's due ... like RUC's projects with orphaned kids. It's not about feeling sorry - its more that the kids of today are the leaders of tomorrow - we have to raise them to be their own people, to be independent, to see the world for what it really is, to make a change and do some things better, they will be here long after we are gone. It's not pity, it's about fixing humanity.

(Atiemo, RUC black male youth aged 19)

This research project is only at the initial stages of exploring the extent to which RUC youth feel they are being shaped by these spiritualities of social justice as change agents in their communities. RUC is clearly not the only influence in their lives. However, engaging voices of youth to see how they interpret RUC's embodiment of liberated relationality in concrete ways can point towards emerging possibilities for cultivating change agents on intersectional social justice, including issues of gender and sexuality. Early results suggest that RUC is playing an influential role in shaping change agents for social justice. Angela offered four examples of how her RUC formation around understanding sin has influenced her as a social change agent. 


\section{Speaking up as a Change Agent within Church}

Angela noted that she became more able to challenge her conservative church cell group theologically by speaking out when she disagreed. This is part of RUC members' commitment to be "upstanders" and not bystanders when they see human injustices enacted or spoken by anyone, including by religious authorities:

I started to challenge other Christians and to speak more about social justice. I went twice a week to the youth cell group [at Church A]. I was uncomfortable initially and felt 'it's not my place to challenge the church leader' but the more we spoke about it at RUC the more I realised that I did have to say something and that you always have a space to be an influence. I remember challenging an issue about unborn babies where they said 'if babies are not baptised they don't go to heaven' and everyone was just nodding and taking notes and I said that is not $0 \mathrm{~K}$. It was my first time to express a dissenting opinion in this religious space.

(Angela, white female youth aged 18)

\section{Moving from Words into Actions}

Angela noted that RUC nurtured her own emerging protest voice moving into a wider awareness of a bigger world, for example, of children affected by war. She recalled that the Minister had ask her to read her protest speech out in church one Sunday.

RUC encouraged our 'protest' voices as youth on bigger issues ... I organised a protest for children affected by war at my school and this action also changed me. Sixty young people were mobilised as a result and came and saw that it 'hit home' for them. I realised how insular my local community was, sheltered, privileged and unaware of the wider world and the need to go beyond self and disrupt the bad things going on out there. I was 16 . I wanted to get people to care about something beyond their comfort zone. Our minister read out my speech in church ... it was important for me to move beyond talking about doing things to doing things.

\section{Modelling Alternative Ways of Seeing Sin}

Angela further noted her increased ability to model alternative ways of seeing sin to peers by being equipped to have discussions, trying to understand where they are coming from and being able to explain her own views better:

In my group of friends at school there were a lot of conversations about right and wrong and many hinged around sex before marriage ... people were so judgemental about other people and said really nasty things like 'God hates them'. Women were also judged more, especially by other women and there was a taboo atmosphere on sex. LGBTIQ was a particular issue ... there was only one openly gay person at my school of 250 people. As I started to talk about it, I encountered repression in the responses my friends gave ... as if they were not allowed to think about it ... Even to start conversations was hard ... straight was the norm and was tied to being a Christian. People straight up say that it's a sin. There was no conversation about heteronormativity; that was a word I heard for the first time at RUC. We also went to Gay Pride as an RUC group and this was an important act for me. I was able to change some people's minds by the end. I showed that you can be a Christian and support gay rights. 


\section{Passing on Inclusive Participatory Pedagogies}

Angela became involved in teaching younger children at RUC in its "holy circus" model. She noted her desire to be an authentic role model for young kids by making connections about how we see God and how society treats others. This played out in her teaching in the church and her involvement in a progressive sex and gender pilot project in high schools:

At RUC, I became a kids' leader. I love the 'Holy Circus' model; it's not like school where there is just teacher and pupil, it evens the playing field and there are all sorts of diverse roles - you can be a lion tamer or a juggler or a clown with a space for everyone. If anyone is left out then the circus is not complete. The circus invites wildness and being out of the box not sitting still and raising your hand. We are allowed to teach about what is important to us and this could be an authentic space. You can't address white privilege with four-year-olds but you can say everyone is equal and it's nice to be able to say that with a church that is behind you.

One of the issues emerging from RUC youth is their desire to challenge churches. Like the prophets of old, they do not merely look outwards or upwards, but within Christianity itself. This can be an uncomfortable exercise for churches that may need to reposition their selfunderstanding as wise repositories of unchanging truth to be passed on to listen to critiques levelled against it by its youth. Many have grown up on stories of the church struggle against apartheid in their parents' time. They are taking this into new "church struggles" ${ }^{\prime 31}$ and their voices may seem uncomfortable to the older generation. As Dan lamented:

My biggest challenge would be the hypocrisy. Often the most Christian people are the ones that get drunk the most, smoke the most weed and do terrible things but then they come to church on Sunday and are 'perfect little princesses'. Also, the whole judgement by churchgoers to non-churchgoers or even to other Christians who do not agree with them. They say they love everyone but their love seems superficial - that love feels very superficial.

(Dan, coloured male youth aged 20)

\section{Conclusion}

To conclude, I affirm that Angela's experience alongside other youth voices emerging from our interviews could reinforce the value of reimagining sin in social, intersectional terms within concrete local congregations. This becomes highly significant in teenage years when understandings of sin often take on narrow, taboo, repressive and distorted associations with the body, emerging sexuality and silence on issues of gender justice. Such associations not only fail to critique dominating patterns of oppression, but even legitimate or ground them theologically and echo uneasily South Africa's theological past of apartheid. The arguable "sin-full-ness" of some church "sin narratives" can lead to an individualised guilt focused on fitting in and the narrow judgements of others, rather than an emphasis on transforming both self and society to nurture Moltmann's "embodied virtue of liberated relationality with the other" ${ }^{32}$ 
Perhaps theological educators need to be better equipped to actively disrupt forms of sin-talk that merely ask youth to conform to disembodied, individualised models of "cookiecutter" perfection and that can underpin attitudes of judgement and hypocrisy that lead increasing numbers of young people to leave churches at an early age or to begin "hiding" their real lives. Much progressive work done at the theological academy around sin is not always translated effectively into actual local congregations where young people experience formation. Our study shows and our young people affirm that RUC remains an important exception in this respect. Can more churches embody and enact ways of reimagining sin to encourage risky journeys of embodied transformation in relation to others, particularly those who are left out, unwelcomed and judged? The RUC experience suggests that it is possible to reimagine our "misplaced identities" of self-justifying domination and aggression by letting go of labels that exclude. In Atiemo's own words:

No baby is born racist - every baby cries when they hear the cry of another ... each baby has the same amount of potential, but then we go out, grow up and are affected by the universe. We are taught our race, roles, what gender we are and what nationality. We grow up trying to protect a fictional identity but they are labels given to us by someone. You are protecting something that is just made up, created by society. From birth we are force fed these labels - people chuck them down our throat and we are forced to chew and swallow and eventually we accept the labels and we end up defending them as they are part of us now - but we should rip them apart. Labels cause division, then conflict, then wars.

(Atiemo, male black youth aged 19)

These words arguably take us to the heart of intersectionality and the multi-dimensional oppressions in which we all remain concretely entangled. The claim of this essay is that true justification requires us to grapple with this understanding if we are to become free together in a shared project of justice-creation. Can churches learn from youth and not just teach; confess and not just preach; and orient towards future possibilities not merely held in captivity to static inherited traditions? Young and Moltmann's "social connection" models offer a framing to first acknowledge and then start to move beyond our intersectional vicious circles. This journey is one that RUC seeks to travel in hope and in participatory partnership with rather than domineering hierarchy over its youth, one of whom remarked: In terms of my spiritual journey, I definitely feel like I have become more sympathetic, empathic towards the world ... I feel things a lot more and I am a lot more content with life. I feel this brings me closer to God, to seeing God in the world.

(Dan, coloured male youth aged 20)

\section{Bibliography}

Bax, Douglas. "The Witness of the Presbyterian Church of Southern Africa 1960-1990," Pages 143-170 in Reformed Churches in South Africa and the Struggle for Justice: Remembering 1960-1990. Edited by Mary-Anne Plaatjies-Van Huffel and Robert Vosloo. Stellenbosch: AFRICAN SUN MeDIA, 2013.

De Gruchy, John and De Gruchy, Steve. The Church Struggle in South Africa. 25th Anniversary Edition. Minneapolis, MN: Fortress Press, 2004.

Maimela, Simon. "Salvation as a Socio-Historical Reality." Inaugural Lecture at the University of South Africa, 1990. 
Moltmann, Jürgen. The Crucified God: The Cross of Christ as the Foundation and Criticism of Christian Theology. London: SCM Press, 1974.

Moltmann, Jürgen. Human Identity and Christian Faith. Stanford, CA: Stanford University Press, 1976.

Moltmann, Jürgen. "The Liberation of Oppressors." Journal of Theology for Southern Africa 26 (1979): 24-37.

Moltmann, Jürgen. Experiences in Theology: Ways and Forms of Christian Theology. London: SCM Press, 2000.

Moltmann, Jürgen. "Sun of Righteousness Arise! The Freedom of a Christian - Then and Now - for the Perpetrators and for the Victims of Sin." Theology Today 69/1 (2012): 7-17. https://doi.org/10.1177/ 0040573611434585

Oden, Patrick. "Liberating Holiness for the Oppressed and the Oppressors." Pages 205-224 in A Future for Holiness: Pentecostal Explorations. Edited by L. Martin. Cleveland, TN: CPT Press, 2013.

Peters, Ted. Sin: Radical Evil in Soul and Society. Grand Rapids, MI: William B. Eerdmans, 1994. https://doi.org/10.3109/00365549409008590

Ruether, Rosemary Radford. Sexism and God-Talk. London: SCM Press, 1983.

Rule, Stephen and Mncwango, Bongiwe. "Christianity in South Africa: Theory and Practice." Pages 185-198 in South African Social Attitudes: 2nd Report. Reflections on the Age of Hope. Edited by B. Roberts, M. Kivilu and Y. Davies. Cape Town: HSRC Press, 2010.

Saiving-Goldstein, Valerie. "The Human Situation: A Feminine View." The Journal of Religion 40/2-(1960): 100-1 12. https://doi.org/10.1086/485231

Tutu, Desmond. No Future without Forgiveness. New York: Doubleday, 1999.

Vasko, Elizabeth. Beyond Apathy: A Theology for Bystanders. Minneapolis, MN: Fortress Press, 2015. https://doi.org/10.2307/j.ctt9m0vv4

Young, Iris M. Justice and the Politics of Difference. Princeton, NJ: Princeton University Press, 1990.

Young, Iris M. Responsibility for Justice. Oxford: Oxford University Press, 201 1. https://doi.org/10.1093/ acprof:oso/9780195392388.001.0001

\section{Endnotes}

1 Ted Peters, Sin: Radical Evil in Soul and Society (Grand Rapids, MI: William B Eerdmans Press, 1994 ), 31.

2 Steven Rule and Bongiwe Mncwango, "Christianity in South Africa: Theory and Practice," in South African Social Attitudes: 2nd Report. Reflections on the Age of Hope, ed. B. Roberts, M. Kivilu and Y. Davies (Cape Town: HSRC Press, 2010), 185-198.

3 This research project Youth Formation for Social Justice (SU-HSD-004323) is being carried out by the author within the Unit for Religion and Development Research (www.sun.ac.za/urdr). All youth quoted are participants in this study with pseudonyms used for confidentiality.

4 Peters, Sin, 4.

5 I owe this phrase to Rosemary Radford Ruether, Sexism and God-Talk (London: SCM Press, 1983), 19.

6 Simon Maimela, "Salvation as a Socio-Historical Reality," Inaugural Lecture at the University of South Africa, 1990, 47.

7 lbid, 52-53.

8 Valerie Saiving Goldstein, "The Human Situation: A Feminine View," The Journal of Religion 40/2 (1960): 100-112 offers the now classic text on this theme on which numerous other feminist scholars have built over the coming decades.

9 Jürgen Moltmann, "Sun of Righteousness Arise! The Freedom of a Christian - Then and Now - for the Perpetrators and for the Victims of Sin," Theology Today 69/1 (2012): 7-17 (13).

10 Douglas Bax, "The Witness of the Presbyterian Church of Southern Africa 1960-1990," in Reformed Churches in South Africa and the Struggle for Justice: Remembering 1960-1990. ed. Mary-Anne PlaatjiesVan Huffel and Robert Vosloo (Stellenbosch: AFRICAN SUN MeDIA, 2013), 143-170.

11 Robert Steiner, personal communication with author, 23 March 2017.

12 See Elizabeth Vasko, Beyond Apathy: A Theology for Bystanders (Minneapolis, MN: Fortress Press, 2015), 7-10.

13 Desmond Tutu. No Future without Forgiveness (New York: Doubleday, 1999), 213.

14 See John de Gruchy and Steve de Gruchy, "From Church Struggle to Church Struggles," in The Church Struggle in South Africa, ed. John de Gruchy (25th Anniversary Edition, Minneapolis, MN: Fortress Press, 2004), 223-260 (229). 
15 Jürgen Moltmann, The Crucified God: The Cross of Christ as the Foundation and Criticism of Christian Theology (London: SCM Press), 343-352.

16 Jürgen Moltmann, Human Identity and Christian Faith, Raymond West Lectures (Stanford, CA: Stanford University Press, 1976), 25.

17 Patrick Oden, "Liberating Holiness for the Oppressed and the Oppressors," in Future for Holiness: Pentecostal Explorations, ed. L. Martin (Cleveland, TN: CPT Press, 2013), 205-224.

18 Jürgen Moltmann, "The Liberation of Oppressors," Journal of Theology for Southern Africa 26 (1979): 24-37 (24).

19 Moltmann, The Crucified God, 346-352. See also Moltmann, Human Identity, 16-18. These liberations are not the focus of this essay, but are tied to the idea of reimagining $\sin$.

20 Moltmann, Sun of Righteousness, 8.

21 Ibid, 13-15.

22 Moltmann, Human Identity, 20.

23 Moltmann, Sun of Righteousness, 15.

24 Jürgen Moltmann, Experiences in Theology: Ways and Forms of Christian Theology (London: SCM Press, 2000), 188.

25 Iris M. Young, Justice and the Politics of Difference (Princeton, NJ: Princeton University Press, 1990).

26 Iris M. Young, Responsibility for Justice (Oxford: Oxford University Press, 2011 ), 95.

27 Ibid, 10.

$28 \mathrm{lbid}, 160$.

29 lbid, 120.

30 More information on SAFCEI (Southern African Faith Communities' Environment Institute) can be found at http://safcei.org/who-we-are/. Last modified 6 November 2017.

31 De Gruchy and De Gruchy, "Church Struggles," 223-260.

32 Moltmann, Human Identity, 20. 



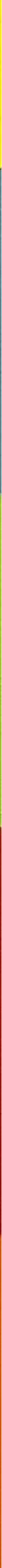




\section{PUSHING BOUNDARIES TOWARDS TRANSFORMATION THROUGH THE POLITICAL THEOLOGY OF DOROTHEE SOELLE AND DENISE ACKERMANN}

Tanya van Wyk Faculty of Theology and Religion University of Pretoria'

\section{Transformation? From where I'm looking, Boundaries for Women Remain Intact}

The year 2017 marked the 100th birthday of the Faculty of Theology at the University of Pretoria. A celebration of this magnitude finds its way into one's theology, because your immediate context is pervaded by it and you are constantly engaged with it. As John de Gruchy rightly has said, "All theology is contextual ... because it develops within a particular historical context." The centenary celebrations at the University of Pretoria took place amidst the greater context of institutional academia in South Africa and the loud call for transformation at all levels. The call for transformation originated from students at institutes of higher learning and reached its zenith during the 2015-2016 \#FeesMustFallmovement across campuses in South Africa. ${ }^{3}$ The call was (and is) for transformation of the curricula and teaching methodologies at universities to reflect the heritage, context and challenges of the environment where the teaching, learning and research are taking place. ${ }^{4}$

The Faculty of Theology as part of the University of Pretoria is, therefore, also dealing with questions and debates about the nature and content of theology. A centenary celebration is a moment when you look to the past and to the future simultaneously, and at UP it is taking place amidst the present calls for transformation and to rethink the content and method of theology. Part of the celebrations entails looking at our past critically, honouring those who contributed to the transformation of church and faculty, and in general pondering the issue of the tension between identity and diversity and trying to discern what the character of a legitimate theological voice in our context would be. 
The Faculty chose as its centenary symbol a pair of gates erected at the Faculty and officially opened on 6 March 2017. The gates are held in a permanent open position with two granite blocks with the dates 1917 on one and 2017 on the other. The main symbolic purpose of the gates is to illustrate the Faculty's openness towards the world and the future, while acknowledging a challenging past. The official slogan of the centenary year is "Gateway to ..." The metaphor of "gates" and "boundaries" is not a theological issue to gloss over. In the world, in Africa, in South Africa and certainly in the scene of Higher Education, there is a real focus and struggle with the notion and practice of hospitality the "invitation to come in". Hospitality is an ambivalent undertaking and as Miroslav Volf 6 describes it, it is a double act of "opening" and "closing"? This struggle with hospitality versus the preferential option for one's own is also witnessed in the United States ${ }^{8}$ where under a different president, America is becoming a nation focused on self-sustainment. The tension between identity and diversity is also witnessed in Europe ${ }^{9}$ where the migration crises have reached a critical level and is further complicated by the decision of the United Kingdom to leave the European Union. ${ }^{10}$ The people of South Africa, too, have witnessed occurrences of xenophobia. ${ }^{11}$

The concern, which forms the departure point of this essay, is whether the answer to the call for transformation, which was to become more inclusive and to reconcile diversity, has been dealt with in an authentic manner. I have observed that debates about the notion of "transformation" in the curriculum and the scene of higher education in general slide over the issue of the unconditional inclusion of women and the utilisation of perspectives of feminist theology as if these are issues of the past that have been dealt with sufficiently. Twenty years ago, Denise Ackermann responded with surprise and melancholy to a British psychologist who described feminism as a "menace to be tackled". ${ }^{2}$ She was incredulous that after so much time such responses still existed. Some things have changed. Some have not.

I am a member and an ordained minister of the Netherdutch Reformed Church (NRCA or known by its Afrikaans abbreviation NHKA). Thirty-six years after my church denomination ordained our first female minister, the main governing body of the church consists of six people, made up of five men and one woman. The general church assembly only voted for a woman after a delegate stood up and reminded the people gathered there that it might be time to have women represented on the council of the general assembly. Our Faculty has appointed three permanent and two part-time female academic theologians in one hundred years. There is currently not a woman in the leadership structure, although there has been one female Head of Department in the history of the Faculty of Theology at the University of Pretoria. ${ }^{13}$ Organising committees aimed at generating discussions about history and transformation did not include female academics. Amidst the centenary celebrations and transformation programmes, Reformed churches worldwide celebrated the 500th commemoration of the Reformation in 2017. Amidst monthly popular articles 
on the Reformation and Reformed theology published in periodicals of the NRCA and scholarly articles from within the church community, only a small number of these publications were dedicated to women who contributed to the Reformation and today contribute to Reformed theology. ${ }^{14}$

In my context, therefore, I witness women working in an environment where barriers to flourishing are firmly in place. ${ }^{15}$ According to Miroslav Volf, "flourishing ... stands for the good life that is lived well, the life that goes well and the life that feels good ... the life worth living." ${ }^{16}$ In institutional academia, the competing, arena-like game atmosphere ${ }^{17}$ is the complete opposite of the "life worth living". The environment leads to women isolating themselves, adhering to life-choking competition and in leadership positions, feel the necessity to exhibit leadership styles corresponding to an empire-like "governance". ${ }^{18}$ In one of his recent articles, Allan Boesak refers to this phenomenon, which is known as "formenism":

like masculinism, [it] subscribes to the belief in the inherent superiority of men over women, but unlike masculinism it is not an ideology developed and sustained by men, but an ideology designed, constructed, and sustained by women. Like its phonetics suggests, this is a concept for men - that is to say, men are the chief beneficiaries of the hierarchical social positioning that it advocates. ${ }^{19}$

The lack of authentic transformation is not a unique situation. ${ }^{20}$ Hillary Rodham-Clinton has described the rights of women and girls as the unfinished business of the 21st century. ${ }^{21}$ From my theological context, I would like to describe it as the unfinished Reformation.

The scene, therefore, is one where there are simultaneous discussions on "transformation" and celebrations of "openness". In this context, my question is about the authenticity of "openness", that is, the hospitality that is reported and portrayed as the main characteristic of theological (and other institutional) endeavours. ${ }^{22}$ How real is advertised inclusivity if the voices of women are not heard, if the contributions that women make are not recognised and if women still do not have a hand in co-creating their own reality? It is about the difference between "openness" or inclusivity as temporary fix to an irritating problem or inclusivity as deep-rooted epistemology. The option, which forms the departure point or basis of one's discussions about transformation, becomes apparent in the way relationships are formed, people address one another (language), the nature of dialogue and the availability of opportunities. Only a different way of "seeing" ontology and a different way of knowing "epistemology" will lead to an authentic way of doing things differently.

Amidst boundaries that exist and lines that are still drawn, this essay is concerned with how to push those boundaries. In doing this, I am turning to political theology as a mode of inquiry and a mode of response. Specifically, I turn to the political theology of Dorothee Soelle and Denise Ackermann. 


\section{Political Theology: Method of Inquiry and Response}

In order to situate and describe Ackerman's and Soelle's methods of "pushing boundaries" within their respective theologies, some general introductory remarks about political theology are necessary.

By describing political theology in "broad strokes", I am deliberately avoiding a definition, because the content of political theology differs in different contexts. ${ }^{23} \mathrm{~A}$ broad definition of political theology includes the way in which the theological and the political impinge upon one another ${ }^{24}$ and the "daily, material concerns that threaten to disintegrate both individual bodies and communal bodies of people". ${ }^{25}$ Political theology as a focus of Christian theology pertains to an inquiry carried out by Christian theologians in relation to the political in which "political" is broadly defined to include the different ways human beings order their common life, ${ }^{26}$ the things that make for the flourishing of human beings and the ordering of life to promote flourishing. ${ }^{27}$ This does not mean that Christian political theology is the only type of political theology. ${ }^{28}$ The experiences described in this essay are taken from a Christian theological context and the respondents to that context belong to a Christian theological paradigm.

Political theology as a theological endeavour and as a subject has a longstanding history of being viewed with suspicion. In his essay titled "Political theology as threat", William Cavanaugh ${ }^{29}$ suggests that this suspicion is based on a one-sided emphasis on the effects of what he describes as bad political theology. This political theology makes an uncritical separation between "politics and "theology" because the mixture of the two would be seen to have disastrous consequences. It is bad, because the complete separation of theology and politics is based on the acceptance of "the fanciful idea that Christianity occupies a religious realm of fantasy and fanaticism, while secular ideologies describe a mundane and sober 'real world." ${ }^{30}$ Furthermore, the separation is also based on the idea that religion in general can be separated from the rest of life - politics, art, economics, social life. Cavanaugh argues that this separation is not self-evident and is "a modern Western invention, not a universal truth of human life."31 Jürgen Moltmann has also offered a similar argument in his existential understanding of the nature of political theology saying, "There is consciously political theology, there is politically un-conscious theology, but there is no such thing as an un-political theology, at least not on this earth and presumably not even in the heavenly politeuma."32

The contemporary discipline of political theology as it has emerged over the past century has been influenced by a combination of events and aspects. One of the influences is the mid-20th century political theology of Europe following World War II, while another is the prominence of liberation theology in Latin America and Africa that together with the liberative politics of womanist, feminist and mujerista theologians have reshaped what we 
understand under political theology. Political theology has emerged also from Christian voices appealing to Christianity to regain a political presence in relation to specific problems. It has emerged as a response to the problem of the inwardness of European Christianity and in response to the problem of how Christianity was co-opted to support slavery, oppression, segregation and violence. ${ }^{33}$ In light of the content of this essay, it is important to mention that a further great stimulus of political theology is the critical insight from feminism that the personal is political. ${ }^{34}$

The main task of political theology is to create and sustain awareness. ${ }^{35}$ Political theology is in a sense a theology of intersectionality, which aims to expose overlapping and multiple systems of discrimination and domination. ${ }^{36}$ In this regard, political theology is a prophetic theology, it is a theology of justice and a theology of a humane society, it is a public theology which is critical of policies, and it is a theology of concrete change. ${ }^{37}$ In the words of Moltmann, what Cavanaugh refers to as "bad political theology" is politicised forms of theology and religion and that is something quite different from political theology. ${ }^{38}$ Politicised theology is akin to situations in which theologians intervene politically or a situation in which a theocracy would be established. The political theology of the mid-20th century is one which is fully engaged in criticism of public affairs - in the tradition of the prophets. After the atrocities of war camps, theology belongs to the realm of public discussion of political freedom, social justice and the future of the earth. Political theology is prophetic theology in different forms, due to different contexts. Resistance against racism led to the birth of black liberation theology in South Africa, as well as the public theology of the civil rights movement in the United States. The outcry against poverty in Latin American gave rise to that specific liberation political theology; the political Minjung theology "of the people" in South Korea was born from the pain and anger of the oppressed ("Han"); existential concerns about the ecological crisis and resistance against the abuse of the environment are the catalyst for an eco-theology of the future of the earth and womanist, feminist and mujerista theologies are protests against patriarchy and violence in different forms in different contexts.

The challenge of political theology is to create a socio-theoretical awareness of the complexity of different relationships - a clearer assessment of the state of affairs based on continuous social analysis and a greater courage to engage with multi-contextual and pluralistic environments. In response to different situations, political theology develops new methodologies, ${ }^{39}$ which include the development of hermeneutical frameworks and methods of correlation towards an authentic theology, which include different disciplines as well as narrative theology and an emphasis between content, method and participation.

The insights from feminist theologians with regard to the practice of political theology as a critical theology are particularly helpful due to their own theological reflections on and criticism of a theology of life that does not take all the participants in that life's experiences 
and perspectives into account. In this regard, the work of Elizabeth Schüssler Fiorenza ${ }^{40}$ considers inclusive language for God and inclusive theological language, but Musa Dube ${ }^{41}$ considers women's experiences and perspectives from the paradigm of deconstructing exclusive colonialist discourses and spaces. Bearing in mind a theology of life that takes all the participants in that life's experiences into account, I now turn to an overview of both the inclusive (political) theology of Dorothee Soelle and Denise Ackermann - theologians from the global north and global south. Their respective theologies illustrate an authentic correlation between content and method by which both of them are pushing boundaries.

\section{The Prophetic Voice of Dorothee Soelle: Pushing Boundaries with Liturgy and Poems}

\section{Spirituality and Activism}

Jürgen Moltmann describes Dorothee Soelle (1929-2003) as "the most well-known and most controversial prophetic voice of the political theology of post-war Germany". ${ }^{2}$ Soelle combined mystical spirituality and political resistance in a unique way - she was both prophet and poet. She was the theologian of groups which protested against nuclear rearmament, groups which opposed environmental destruction and capitalism, and groups which protested against dictatorship, because these were the issues against which she protested in a very existential manner. Her theology developed out of disillusionment with how her family privately criticised Hitler, but publicly supported him as well as the German Protestant church's complicity in the Holocaust. ${ }^{43}$ This disappointment also included the limitations she experienced due to her gender. At a young age, she was dismayed that her "having breasts" was a symbol of her exclusion from the privilege that boys and men in her society enjoyed with regard to opportunities and adventure. ${ }^{44}$

In this essay, I focus on the way Soelle pushed boundaries in her political theology ${ }^{45}$ with her prophetic voice and activism, especially by means of the political evensong (Kölner Nachtgebet) that she organised during 1968-1972. Through these political night prayers, she aimed at the "politicization of the conscience" because she believed that theology must reflect her own social and political situation in the conflict of her time. ${ }^{46}$

\section{Struggle and Contemplation}

The political evensong started out as a discussion group of people (Protestant and Roman Catholic Christians) who wanted to exchange ideas about current political and social issues. ${ }^{47}$ The discussions were based on the realisation by members of the group that dealing with theological issues necessarily leads to political engagement. Their approach to these gatherings was called "struggle and contemplation" (lute et contemplation). This approach and method were also practised at the ecumenical cloister of Taize. The gatherings started 
to follow a pattern which comprised four elements, namely information, meditation, discussion and action, based on the principle "see, judge, act". 48

When the group applied for permission to celebrate a political prayer liturgy about current political issues during the convocation of Catholics in 1968 in Essen, the liturgy was scheduled only for 23:00 - and that is how the political night prayer got its name: "Our pattern was to provide political information, to confront the information with biblical texts, someone would give a brief talk, then there would be calls for action, and discussion with the gathered congregation: information; meditation; action." ${ }^{49}$ During these gatherings, issues such as the Vietnam War, the intervention of the United States in Santa Domingo and societal problems like discrimination against women and the treatment of prisoners were discussed. The 9th political evensong in 1971 had as its motto "The emancipation of women - Woman is still on the bottom". The evensongs were attended by a great number of people. In fact, a Cologne newspaper reported in 1968 that the St. Anthony's Church could seat 300 people, but by 20:30 it was already overflowing and 10 minutes later there was no standing room left. ${ }^{50}$ Over 1,000 people had come to attend. It was an ambivalent occurrence for its time. Church authorities had tried to deny the evensong permission to take place and a movement "from below" (ordinary, non-clergy, non-church-going people) was a reason for church authorities to become agitated or even nervous. Many others in the church sensed that the church was finally opening itself to the world and to human beings with their longings, problems and hopes.

The deepest roots of the "methodology" of Dorothee Soelle's activism (and political theology) can be traced back to her mystical spirituality, because mysticism is an antiauthoritarian element as she later described in her book The Silent Cry: Mysticism and Resistance. ${ }^{51}$ Mysticism is an all-inclusive experience. It can happen every day to everyone. Within this experience, one is united with the mystery that is named God and a person is liberated from ego, violence, anxiety and greed. This is the best preparation for resistance against a wasteful, consumerist society and an alternative life. Soelle believed that a different world is a real possibility. ${ }^{52}$

From the connection and mutual influence of Soelle's mystic spirituality and political activism, her poems were born. They became the bearers of theological substance and a different kind of piety (spirituality) as she provided a new theological language and a new theological perspective for the generation of her time. The language of poetry renders meaning and resonates with others, because of its narrative freedom and the linguistic means available, namely hyperbole, repetition, comparison and paradox. ${ }^{53}$ Her poems expressed a praxis for resistance and ethics for human beings. ${ }^{54} \mathrm{With}$ this, theology became more accessible to a variety of expressions: "Theological concepts are those that represent human beings in their totality and relate them to eternal life, that is, their authentic life, for 
example sin, grace, dying, rising again, justice and peace." ${ }^{55}$ For Soelle, poetry was prayer and prayer was poetry:

For me, praying and writing poetry, prayer and poem, are not alternatives. The message I wish to pass on is meant to encourage people to learn to speak themselves. For example, the idea that every human being can pray is for me an enormous affirmation of human creativity. Christianity presupposes that all human beings are poets, namely, they can pray. That is the same as seeing with the eyes of God. When people try to say with the utmost capacity for truthfulness what really concerns them, they offer prayer and are poets at the same time. To discover this anew, to bring it into reality or make it known, is one of the goals I pursue in my poems. ${ }^{56}$

Soelle's political evensongs and her poems were inclusive in two ways - the evensong was accessible because of the liturgy, and the poems were accessible due to the language. With liturgy and language, Soelle created a just praxis and practised authentic theology, which challenged one's relationship to the world and in the process challenged boundaries. Her theology was not theology for theology's sake. It is important to take note of this in light of my previous remarks in the introduction of this essay about the authenticity of the theology that is practised with regard to who it is really aimed at, who participates in it and the people it includes in an authentic way. This very aspect of Soelle's theology is the reason I bring her in a short conversation with Denise Ackermann whose "simple and straightforward" 57 way of doing theology is very much concerned with the accessibility of theology and the praxis of human beings. Soelle used liturgy and poems, Ackermann used letters. It is to this example that I now turn in more detail.

\section{The Prophetic and Transformative Voice of Denise Ackermann}

\section{Challenging Boundaries by Writing Letters}

By her own description, Denise Ackermann (born 1935) is a "feminist theologian of praxis".58 She came to feminist theology through liberation theology and her feminist theological reflection focuses on the construction of inclusive and affirming theories and practices for all who experience marginalisation and oppression. ${ }^{59}$ It is for this reason that I describe Ackermann in this essay as a political theologian. Her critical and contextual theology connects theology, feminism, ideology, the Bible, the church and the way we speak about God. ${ }^{60}$ Her way to theology and faith (not religion) was not a marked-out path and certainly not straightforward. She grew up in many countries, because her parents were diplomats and she came to theology only in her forties. In terms of the South African situation, from the "outside" she looked "in" and became uncomfortable with straightforward and uncontested privilege of which she admits to have reaped the benefits. She, therefore, experienced and struggled with notions of identity and difference for a great part of her life.

Ackermann's theology and methods of doing theology reflect her drive towards practising an inclusive theology of transformation. As an academic professor, partaking in the world 
of institutional academia and its many demands for measured output, she decided not to write only for the limited circle of the academy. She chose to write letters to "people who mattered to me, about the themes that have been at the core of my search for healing and freedom and about my efforts to discover what is worth living for in troubled times." ${ }^{61}$ Ackermann emphasised the potential of theology to change people and that is the basis of her conviction that theology is not an "inward-looking academic game" 62 and cannot, therefore, be limited to the inner circle of theologically trained people. The overarching style of her theology is writing clearly and deconstructing complex theological doctrines and philosophical concepts.

In a way, Ackermann's methodological approach is just as anti-institutional as Soelle's mystical poems and her organisation of evensongs. In my view, Ackermann's approach to political theology has a twofold character - it is both courageous and creative. Letters do not contain academic styles of referencing or footnotes. One cannot rely on the authority of others. You have to say what you mean up front. ${ }^{63}$ In her letters, her prophetic voice is heard from the context of her own experiences. In this regard, Dirkie Smit compares Ackermann to John Calvin. ${ }^{64}$ John de Gruchy compares her to Dietrich Bonhoeffer ${ }^{65}$ in terms of the scope and range (influence) of the letters he wrote from prison. Writing letters is a way of sharing your deepest thoughts - about faith and doubt, depression and hope. It is rather more prophetic and effective than large volumes of theology of an academic and systematic kind. It is inclusive and is existential. De Gruchy is, however, also of the opinion that Ackermann's letter-writing is "a kick in the butt for academic theologians ... who have lost their love of doing theology".66

\section{Meeting the Challenge of Difference}

An important aspect of Ackermann's approach to doing theology is the way in which she faces difference. For boundaries to be crossed, the challenge of difference has to be met. Ackermann writes:

If we are to form strategies for change, we need to network, to dialogue, to exchange views particularly with those who differ from us in terms of culture, context and religion. We must embrace difference, particularly when it challenges us. ${ }^{67}$

Embracing difference is a central theme in Ackermann's theology. She takes up this theme in several of her works as she reflects on the role and space of women in society, ${ }^{68}$ especially pertaining to the challenges they face in a post-apartheid South Africa. Furthermore, she considers how churches can work together to address the broken human condition. ${ }^{69}$ For Ackermann, a necessary and non-negotiable aspect of doing theology is to provide a type of vocabulary that seeks to ask questions and to describe the issues that acknowledges, even demands, seemingly contradictory conditions to be present and active at the same 
time. This involves naming the ambiguities, contradictions and ambivalence when dealing with difference.

Moreover, identity is an important marker in Ackermann's landscape. She argues that identity questions are characterised by differences and shared sameness. ${ }^{70}$ Living in this landscape of difference and sameness means that questions of identity will not disappear. Identity for her has a double meaning - how you belong/are the same and how you are different. Identity becomes dangerous if one form of identity is elevated above other manifestations of identity. Identity can thus be viewed as a bond or a bondage. Ackermann notes that the temptation is often to either embrace the identity of one's family or culture uncritically, or "to adopt a full identity from an alternative culture with equally little self-reflection". ${ }^{71}$ Ackermann maintains, however, both distance and belonging, simultaneously can be said to be necessary conditions when it comes to the self-description or self-determination of identity. Belonging without distance tends to be destructive. Distance without belonging may result in isolation. Difference or otherness is for Ackermann simply the adventure of the diversity of human beings. To speak of difference is to speak of gender, race, class, poverty, justice, of human sexuality and history and tradition. It is the differences between people and the way people deal with difference that shape identities.

Identity is also linked to the space that is occupied or inhabited. Total inclusion collapses all borders. When this happens, the criteria and ability for distinguishing between repressive identity and affirming identity is lost. Borders are ambiguous. Borders can demarcate a space for personal (the unique self) development and growth. But it can exclude from real conversation and the possibility of change. Borders are necessary though. Otherwise, the reaction to incursions will be to react violently outwardly or retreat into exclusion. An over-emphasis or non-acknowledgment of difference is the result when borders collapse. Identity is shaped by a creative tension between inclusivity and exclusivity and by ongoing dialogue. ${ }^{72}$

Ackermann's theology, therefore, exhibits distinctive traits of a mystical spirituality (of Soelle) described above. To be able to deal with difference requires an acceptance of the mystery of the human condition and the mystery that is God. In the foreword of her awardwinning book Surprised by the Man on the Borrowed Donkey, ${ }^{73}$ Ackermann states that theology and spirituality are inseparable. To live with the gospel means to embrace paradox and contradiction and "to live fruitfully with questions".74

In her theology, Ackermann thus emphasises the vital importance of pushing or transcending boundaries. This is done by acknowledging and celebrating difference, but at the same time finding your own voice. This is especially true for women doing theology. Ackermann levelled the playing field by co-creating transformative spaces in which theology is expressed and lived. 


\section{Conclusion - Agents of Change}

Both Soelle and Ackermann emerge as agents of change due to the authenticity of their contributions and the transformation of self and others that resulted from these. The authenticity is not only to be found in their prophetic voices, but in the way they practised prophetic and critical theology in the form of liturgy, poems and letters which are accessible to all. Both were (Ackermann still is) concerned with creating and sustaining awareness and had the courage to engage multi-contextual and pluralistic environments. Their theology uncovers and criticises power, paradigms and policies that stimulate and perpetuate oppression, alienation and violence. Their critical reflections on what makes life worth living and how life can be better take all the participants in that life's experiences and perspectives into account. Their theological methods are indicative of authentic theology for others, which is only possible if there is equal participation. With regard to the example cited in the introduction of this essay, open gates and authentic transformation are only possible where there is equal participation and access. The acceptance speech of African-American actress Viola Davis at the Emmy awards for film and television in 2015 is a profound statement of how boundaries can only be crossed if there is opportunity for equal participation and the active creation of opportunities for all to flourish. She says:

In my mind, I see a line. And over that line, I see green fields and lovely flowers and beautiful white women with their arms stretched out to me over that line. But I can't seem to get there no how. I can't seem to get over that line. That was Harriet Tubman in the 1800 s... let me tell you something: The only thing that separates women of colour from anyone else is opportunity. You cannot win an Emmy for roles that are simply not there. ${ }^{75}$

\section{Bibliography}

Ackermann, Denise M. "Forward from the Margins. Feminist Theologies for Life." Journal of Theology for Southern Africa 9 (1997): 63-67.

Ackermann, Denise M. "Becoming Fully Human: An Ethic of Relationship in Difference and Otherness." Journal of Theology for Southern Africa 102 (1998): 13-27.

Ackermann, Denise M. After the Locusts. Letters from a Landscape of Faith. Grand Rapids, MI: Eerdmans, 2003.

Ackermann, Denise M. "'Found Wanting and Left Untried?' - Confessions of a Ragbag Theologian." Pages 267-286 in Ragbag Theologies. Essays in Honour of Denise M. Ackermann. A Feminist Theologian of Praxis. Edited by Miranda Pillay, Sarojini Nadar and Clint de Bruyns. Stellenbosch: AFRICAN SUN MeDIA, 2009.

Ackermann, Denise M. Surprised by the Man on the Borrowed Donkey. Ordinary Blessings. Cape Town: Lux Verbi, 2014.

Boesak, Allan A. "The Riverbank, the Seashore and the Wilderness: Miriam, Liberation and Prophetic Witness against Empire." HTS Teologiese Studies/Theological Studies 73(4) (2017): 1 - 10. https://doi.org/10.4102/ hts.v73i4.4547

Buchanan, Larry and Peçanha, Sergio. "Europe Tries to Shut Down Routes as Migrant Flow Intensifies." The New York Times. 11 March 2016. Cited 26 July 2017.Online: https://www.nytimes.com/interactive/ 2016/03/11/world/europe/europe-tries-to-shut-down-routes-as-migrant-flow-intensifies.html

Cavanaugh, William T.; Bailey, Jeffrey W. and Hovey, Craig, ed. An Eerdmans Reader in Contemporary Political Theology. Grand Rapids, MI: Eerdmans, 2012. 
Cavanaugh, William T. "Political Theology as Threat." Pages 236-255 in The Cambridge Companion to Christian Political Theology. Edited by Craig Hovey and Elizabeth Phillips. New York: Cambridge, 2015. https://doi.org/10.1017/CCO9781107280823.013

Claassens, Juliana M. "Safe Spaces Are Found When Women Can Thrive," Cape Argus Early. 2 August 2017. Cited 4 August 2017. Online: http://www.sun.ac.za/english/Documents/newsclips/JClaassens_CapeArgus Aug2017.pdf

Crenshaw, Kimberlé. "Demarginalizing the Intersection of Race and Sex: A Black Feminist Critique of Antidiscrimination Doctrine, Feminist Theory and Antiracist Politics." University of Chicago Legal Forum 140 (1989): 139-167.

De Gruchy, John W. "The Nature, Necessity and Task of Theology." Pages 2-14 in Doing Theology in Context: South African Perspectives. Edited by John de Gruchy and Charles Villa-Vicencio. Maryknoll, NY: Orbis Books, 1994.

De Gruchy, John W. "On Locusts and Wild Honey: Letter Writing as Doing Theology." Pages 175-184 in Ragbag Theologies. Essays in Honour of Denise M. Ackermann. A Feminist Theologian of Praxis. Edited by Miranda Pillay, Sorojini Nadar and Clint de Bruyns. Stellenbosch: AFRICAN SUN MeDIA, 2009.

Dube, Musa. "Toward a Post-colonial Feminist Interpretation of the Bible." Pages 585-600 in An Eerdmans Reader in Contemporary Political Theology. Edited by William T. Cavanaugh, Jeffrey Bailey and Craig Hovey. Grand Rapids, MI: Eerdmans, 2012.

Du Preez, Petro; Simmonds, Shan and Verhoef, Anné H. "Rethinking and Researching Transformation in Higher Education: A Meta-study of South African Trends." Transformation in Higher Education 1/1 (2016). Cited 25 July 2016. Online: https://doi.org/10.4102/the.v1i1.2

Edwards Ainsley, Julia. "Trump Moves Ahead with Wall, Puts Stamp on U.S. Immigration, Security Policy." Reuters. 25 January 2017. Cited 26 July 2017. Online: http://www.reuters.com/article/us-usa-trumpimmigration-idUSKBN1591HP

Geddes, Andrew and Scholten, Peter. The Politics of Migration and Immigration in Europe. London and New York: Sage, 2016. https://doi.org/10.4135/9781473982703

Hadebe, Nontando M. "Commodification, Decolonisation and Theological Education in Africa: Renewed Challenges for African Theologians." HTS Teologiese Studies/ Theological Studies 73(3) (2017): 10 pages.

Hanisch, Carol. "The Personal Is Political." Pages 76-77 in Notes from the Second Year: Women's Liberation. Edited by Shulamith Firestone and Anne Koedt. New York: Radical Feminist, 1970.

Heyman, Jessie. "Viola Davis Gave the Most Powerful Emmy Awards Acceptance Speech of All Time." Vogue. 2 September 2015. Cited 25 July 2017. Online: https://www.vogue.com/article/viola-davis-emmys2015-acceptance-speech

Hovey, Craig and Phillips, Elizabeth, ed. The Cambridge Companion to Christian Political Theology. New York: Cambridge, 2015. https://doi.org/10.1017/CCO9781107280823

Kekana, Masa; Isaacs, Lana and Corke, Emily. "Tuition Fee Protests Shut down 2 of SA's Biggest Universities," Eyewitness News. 19 October 2015. Cited 18 July 2017. Online: http://ewn.co.za/2015/10/19/Feeprotests-shuts-down-3-of-SAs-biggest-universities

Masuku, Themba. "Targeting Foreigners: Xenophobia among Johannesburg's Police." SA Crime Quarterly 15 (2006): 19-24.

Moltmann, Jürgen. "Political Theology in Ecumenical Contexts." Pages $1-12$ in Political Theology. Contemporary Challenges and Future Directions. Edited by Francis Schüssler Fiorenza, Klaus Tanner and Michael Welker. Louisville, KY: Westminster John Knox, 2013.

Moltmann, Jürgen. "European Political Theology." Pages 3-22 in The Cambridge Companion to Christian Political Theology. Edited by Craig Hovey and Elizabeth Phillips. New York: Cambridge, 2015. https://doi.org/10.1017/CCO9781 107280823.002

Nadar, Sarojini and Potgieter, Cheryl. "Living It out. Liberated through Submission? The Worthy Woman's Conference as a Case Study of Formenism." Journal of Feminist Studies in Religion 26 (2010):141-151. https://doi.org/10.2979/fsr.2010.26.2.141

Naidoo, Marilyn. "Transformative Remedies towards Managing Diversity in South African Theological Education." HTS Teologiese Studies/Theological Studies 71/2 (2015): 7 pages.

Nordland, Rod. "A Mass Migration Crisis, and It May Yet Get Worse." The New York Times. 31 October 2015. Cited 26 July 2017. Online: https://www.nytimes.com/2015/11/01/world/europe/a-mass-migrationcrisis-and-it-may-yet-get-worse.html 
Phillips, Elizabeth. Political Theology. A Guide for the Perplexed. London: T\&T Clark, 2012.

Pinnock, Sarah K. The Theology of Dorothee Soelle. Harrisburg, PA: Trinity International, 2003.

Ranjeni, Munusamy. "\#FeesMustFall: Political Failure Triggers Ticking Time Bomb." Daily Maverick.

21 October 2015. Cited 17 July 2017. Online: https://www.dailymaverick.co.za/article/2015-10-21feesmustfall-political-failure-triggers-ticking-time-bomb/\#.WYmoZ1 EjHIU

Rumscheidt, Martin. "A Calling in a Higher Sense: The Poetics of Dorothee Soelle." Pages 71-89 in

The Theology of Dorothee Soelle. Edited by Sarah K. Pinnock. Harrisburg, PA: Trinity International, 2003.

Schüssler Fiorenza, Elizabeth. "Critical Feminist The*logy of Liberation: A Decolonizing Political The*logy." Pages 23-36 in Political Theology. Contemporary Challenges and Future Directions. Edited by Francis Schüssler Fiorenza, Klaus Tanner and Michael Welker. Lovisville, KY: Westminster John Knox, 2013.

Schüssler Fiorenza, Francis. "Political Theology as Foundational Theology." The Catholic Theological Society of America 32 (1977): 142-177.

Schüssler Fiorenza, Francis; Tanner, Klaus and Welker, Michael, ed. Political Theology. Contemporary Challenges and Future Directions. Louisville, KY: Westminster John Knox, 2013.

Smit, Dirkie J. "Simple and Straightforward? On Doing Theology." Pages 157-176 in Ragbag Theologies. Essays in Honour of Denise M. Ackermann. A Feminist Theologian of Praxis. Edited by Miranda Pillay, Sarojini Nadar and Clint de Bruyns. Stellenbosch: AFRICAN SUN MeDIA, 2009.

Soelle, Dorothee. "Thesen über die Kriterien des Theologischen Interesses an Literatur." Almanach für Literatur und Theologie 4 (1970): 206-207.

Soelle, Dorothee. Political Theology. A Critical Reflection on Rudolf Bultmann. Translated by B. Rumshceidt and M. Rumscheidt. Philadelphia, PA: Fortress, 1974.

Soelle, Dorothee. Against the Wind: Memoir of a Radical Christian. Translated by Martin Rumscheidt and Barbara Rumscheidt. Munich: Hoffmann and Campe, 1999.

Soelle, Dorothee. Mysticism and Resistance. Translated by Martin Rumscheidt and Barbara Rumscheidt. Minneapolis, MN: Fortress Press, 1997.

Soelle, Dorothee and Steffensky, Fulbert, ed. Politisches Nachtgebet in Köln. Vols. 1 \& 2. Stuttgart: Kreuz, 1969 and 1971.

Soergel, Andrew. "Trump Pushing to Cut Annual Immigration by Half. Trump Reportedly in Discussions with GOP Lawmakers about an Immigration Bill," U.S. News. 13 July 2017. Cited 26 July 2017. Online: https://www.usnews.com/news/national-news/articles/2017-07-13/report-trump-pushing-to-cut-annualimmigration-by-half

Tella, Oluwaseun. "Understanding Xenophobia in South Africa: The Individual, the State and the International System." Sage Journals. Politics and International Relations 8/2 (2016): 142-158. https://doi.org/10.1177/ 0975087816655014

Van Niekerk, Sacha. "Students Take on Blended Learning," Independent on Saturday. 12 November 2016. Cited 18 July 2017. Online: http://www.iol.co.za/ios/news/students-take-on-blended-learning-2089470

Van Wyk, Tanya. "Political Theology as Critical Theology." HTS Theological/Teologiese Studies 71 (3) (2015): 1-7. https://doi.org/10.4102/hts.v71i3.3026

Van Wyk, Tanya. "Let us Play: (Un)shackling Liaisons, (Un)masking Games and (Un)hindered Dialogue in the Arena Where Theology Takes Place." Pages 246-279 in Ecodomy - Life in lts Fullness. Brokenness and Wholeness. Edited by Dirk J. Human. Verbum et Ecclesia, Suppl. 1, 38/3. Cape Town: AOSIS, 2017. https://doi.org/10.4102/ve.v38i3.1659

Van Wyk, Tanya. "Die Protestantse Vrou Wat nie Kon Stilbly nie: Argula von Grumbach (1492-1554)." Konteks 28/6 (2017): 22-23.

Van Wyk, Tanya. “Ursula von Münsterberg (1491-1534). Die Non Wat Konvensie Verbreek Het en Hervorming Bewerkstellig Het." Konteks 28/7 (2017): 23-24.

Van Wyk, Neltjie C. and Van Wyk, Tanya. "Die Lewe en Werk van Frances Young (1939-) en Dorothee Sölle (1929-2003): 'n Leksikografiese Bydrae tot Reformasie 500." HTS Teologiese Studies/ Theological Studies 73/1 (2017): 1-6. https://doi.org/10.4102/hts.v73il.4671

Volf, Miroslav. "Exclusion and Embrace: Theological Reflection in the Wake of 'Ethnic Cleansing'." Occasional Papers on Religion in Eastern Europe 13/6 (1993): 1-6.

Volf, Miroslav. Flourishing: Why We Need Religion in a Globalized World. New Haven and London: Yale, 2016.

Wind, Renate. Dorothee Soelle - Mystic and Rebel. The Biography. Translated and edited by N. Lukens and M. Rumscheidt. Minneapolis, MN: Fortress, 2012. 


\section{Endnotes}

1 This essay is a revised version of a paper of the same title, delivered at the launch-conference of the Gender Unit at the Faculty of Theology, Stellenbosch University during 28-30 March 2017.

2 John de Gruchy, "The Nature, Necessity and Task of Theology," Doing Theology in Context: South African Perspectives, ed. John de Gruchy and Charles Villa-Vicencio (New York: Orbis, 1994), 9.

3 Cf. Masa Kekana, Lauren Isaacs and Emily Corke, "Tuition Fee Protests Shut down 2 of SA's Biggest Universities," Eyewitness News (19 October 2015). Cited 18 July 2017. Online: http://ewn.co.za/ 2015/10/19/Fee-protests-shuts-down-3-of-SAs-biggest-universities. Sacha van Niekerk, "Students Take on Blended Learning," Independent on Saturday (12 November 2016). Cited 18 July 2017. Online: http://www.iol.co.za/ios/news/students-take-on-blended-learning-2089470. Munusamy Ranjeni, "\#FeesMustFall: Political Failure Triggers Ticking Time Bomb," Daily Maverick (21 October 2015). Cited 17 July 2017. Online: https://www.dailymaverick.co.za/article/2015-10-21-feesmustfall-politicalfailure-triggers-ticking-time-bomb/\#.WYmoZ1 EjHIU

4 Petro du Preez, Shan Simmonds and Anné H. Verhoef, "Rethinking and Researching Transformation in Higher Education: A Meta-study of South-African Trends," Transformation in Higher Education 1/1 (2016). Cited 25 July 2016. Online: http://dx.doi.org/10.4102/the.v1i1.2. Nontando M. Hadebe, "Commodification, Decolonisation and Theological Education in Africa: Renewed Challenges for African Theologians," HTS Teologiese Studies/ Theological Studies 73/3 (2017): 10 pages. Marilyn Naidoo, "Transformative Remedies towards Managing Diversity in South African Theological Education," HTS Teologiese Studies/Theological Studies 71/2 (2015): 7 pages.

5 Ansa Heyl, "Official Opening and Reinstatement of the Gates at the Faculty of Theology" (6 March 2017). Cited 25 July 2017. Online: http://www.up.ac.za/en/news/post_2426682-official-opening-andreinstatement-of-the-gates-at-the-faculty-of-theology

6 Miroslar Volf, "Exclusion and Embrace: Theological Reflection in the Wake of 'Ethnic Cleansing'," Occasional Papers on Religion in Eastern Europe 13/6 (1993): 1-6.

7 Ibid, 16.

8 Julia Edwards Ainsley, "Trump Moves Ahead with Wall, Puts Stamp on U.S. Immigration, Security Policy," Reuters (25 January 2017). Cited 26 July 2017. Online: http://www.reuters.com/article/us-usa-trumpimmigration-idUSKBN1591HP. Andrew Soergel, "Trump Pushing to Cut Annual Immigration by Half. Trump Reportedly in Discussions with GOP Lawmakers about an Immigration Bill," U.S. News (13 July 2017). Cited 26 July 2017. Online: https://www.usnews.com/news/national-news/articles/2017-07-13/reporttrump-pushing-to-cut-annual-immigration-by-half

9 Rod Nordland, "A Mass Migration Crisis, and It May Yet Get Worse," The New York Times. 31 October 2015. Cited 26 July 2017. Online: https://www.nytimes.com/2015/11/01/world/europe/a-mass-migrationcrisis-and-it-may-yet-get-worse.html. Larry Buchanan and Sergio Peçanha, "Europe Tries to Shut down Routes as Migrant Flow Intensifies," The New York Times. 11 March 2016. Cited 26 July 2017. Online: https://www.nytimes.com/interactive/2016/03/1 1/world/europe/europe-tries-to-shut-down-routesas-migrant-flow-intensifies.html. Andrew Geddes and Peter Scholten. The Politics of Migration and Immigration in Europe (London and New York: Sage, 2016).

10 On 23 June 2016, a slight majority (51.9\%) of the population of the United Kingdom voted to leave the European Union and is on course to leave in March 2019.

11 Oluwaseun Tella, "Understanding Xenophobia in South Africa: The Individual, the State and the International System," Sage Journals. Politics and International Relations 8/2 (2016): 142-158. Themba Masuku, "Targeting Foreigners: Xenophobia among Johannesburg's Police," SA Crime Quarterly 15 (2006): 19-24. Angelo Fick, "Am I an African? On Xenophobia and Violence in South Africa," E-News Channel Africa (24 February 2017). Cited 3 March 2017. Online: http://www.enca.com/opinion/am-i-anafrican-on-xenophobia-and-violence-in-south-africa-2017

12 Denise M. Ackermann, "Forward from the Margins. Feminist Theologies for Life," Journal of Theology for Southern Africa 9 (1997): 63-67.

13 Professor Yolanda Dreyer was the Head of the Department of Practical Theology at the Faculty of Theology at the University of Pretoria from November 2010 to February 2015.

14 Neltjie C. van Wyk and Tanya van Wyk, "Die Lewe en Werk van Frances Young (1939-) en Dorothee Sölle (1929-2003): 'n Leksikografiese Bydrae tot Reformasie 500," HTS Teologiese Studies/ Theological Studies 73/1 (2017): 1 -6. Tanya van Wyk, "Die Protestantse Vrou Wat nie Kon Stilbly nie: Argula von Grumbach (1492-1554)," Konteks 28/6 (2017): 22-23. Tanya van Wyk, “Ursula von Münsterberg (1491-1534): Die Non Wat Konvensie Verbreek Het en Hervorming Bewerkstellig Het," Konteks 28/7 (2017): 23-24. 
15 Cf. L. Juliana M. Claassens, "Safe Spaces Are Found When Women Can Thrive," Cape Argus Early (2 August 2017). Cited 4 August 2017. Online: http://www.sun.ac.za/english/Documents/newsclips/ JClaassens_CapeArgus_Aug2017.pdf

16 Miroslav Volf, Flourishing: Why We Need Religion in a Globalized World (New Haven and London: Yale, 2016), ix.

17 Tanya van Wyk, "Let Us Play: (Un)shackling Liaisons, (Un)masking Games and (Un)hindered Dialogue in the Arena Where Theology Takes Place," Ecodomy - Life in Its Fullness: Brokenness and Wholeness, ed. Dirk J. Human, Verbum et Ecclesia suppl. 1, 38/3: 246-279.

18 Allan A. Boesak, "The Riverbank, the Seashore and the Wilderness: Miriam, Liberation and Prophetic Witness against Empire," HTS Teologiese Studies/ Theological Studies 73/4 (2017): 1-10. For the original usage of this term, see Sarojini Nadar and Cheryl Potgieter, "Living It out. Liberated through Submission? The Worthy Woman's Conference as a Case Study of Formenism," Journal of Feminist Studies in Religion 26 (2010): $141-151$.

19 Boesak, The Riverbank, 4.

20 Claassens, "Safe Spaces," 9.

21 Hillary Clinton made this remark during a "Women for Women International Conference", while being interviewed by CNN journalist Christiane Anampour on 2 May 2017. Cited 25 July 2017. Online: http://observer.com/2017/05/hillary-clinton-speech-at-women-for-women-international-luncheon/

22 Van Wyk, "Let Us Play," 246-248.

23 Cf. Tanya van Wyk, "Political Theology as Critical Theology," HTS Theological/Teologiese Studies 71/3 (2015): 1-7.

24 Craig Hovey and Elizabeth Phillips, ed., The Cambridge Companion to Christian Political Theology (New York: Cambridge, 2015), xi.

25 Cf. William T. Cavanaugh, Jeffrey W. Bailey and Craig Hovey, ed., An Eerdmans Reader in Contemporary Political Theology (Grand Rapids, MI: Eerdmans, 2012), xxiv.

26 Hovey and Phillips, Christian Political Theology, xii.

27 Elizabeth Phillips, Political Theology. A Guide for the Perplexed (London: T \& T Clark, 2012), 2.

28 Ibid, 3-4

29 William T. Cavanaugh, "Political Theology as Threat," in The Cambridge Companion to Christian Political Theology, ed. Craig Hovey and Elizabeth Phillips (New York: Cambridge, 2015), 236-255.

30 Cavanaugh, "Political Theology as Threat," 251.

31 lbid, 252.

32 Jürgen Moltmann, "Political Theology in Ecumenical Contexts," in Political Theology. Contemporary Challenges and Future Directions, ed. Frances Schüssler Fiorenza, Klaus Tanner and Michael Welker (Louisville, KY: Westminster John Knox, 2013), 1-12.

33 Hovey and Phillips, Christian Political Theology, xii-xiii.

34 The origin of the phrase, "the personal is political" is reportedly traced to the theme of an article by Carol Hanisch, which defended the political importance of groups that create awareness. Although Hanisch did not use the phrase, the article was published in 1970 under the title, "The Personal is Political," in Notes from the Second Year: Women's Liberation, ed. Shulamith Firestone and Anne Koedt (New York: Radical Feminist, 1970), 76-77.

35 Frances Schüssler Fiorenza, Klaus Tanner and Michael Welker, ed. Political Theology. Contemporary Challenges and Future Directions (Louisville, KY: Westminster John Knox, 2013), 11.

36 My argument is that political theology shows characteristics of 'intersectionality' - a term that was coined by Kimberlé Williams Crenshaw to denote a way of acknowledging multiple social identities and overlapping systems of domination and or exclusion that result in various experiences of disadvantage or advantage. Crenshaw coined this term from her experience as a black woman and the intersection and overlapping of gender, racial and social class identities. It could be argued (although it is not explored here in detail) that intersectionality is part and parcel of political theology as a critical theology that creates and sustains awareness. For further reading, see Kimberlé Crenshaw, "Demarginalizing the Intersection of Race and Sex: A Black Feminist Critique of Antidiscrimination Doctrine, Feminist Theory and Antiracist Politics," University of Chicago Legal Forum 140 (1989): 139-167.

37 Van Wyk, "Political Theology," 6-7.

38 Jürgen Moltmann, "European Political Theology," in The Cambridge Companion to Christian Political Theology, ed. Craig Hovey and Elizabeth Phillips (New York: Cambridge, 2015), 3-22. 
39 Francis Schüssler Fiorenza, "Political Theology as Foundational Theology," The Catholic Theological Society of America 32 (1977): 142-177.

40 Elizabeth Schüssler Fiorenza, "Critical Feminist The*logy of Liberation: A Decolonizing Political The*logy in Political Theology. Contemporary Challenges and Future Directions, ed. Frances Schüssler Fiorenza, Klaus Tanner and Michael Welker (Louisville, KY: Westminster John Knox, 2013), 23-36.

41 Cf. Musa Dube, "Toward a Post-colonial Feminist Interpretation of the Bible," in An Eerdmans Reader in Contemporary Political Theology, ed. William T. Cavanaugh, Jeffrey Bailey and Craig Hovey (Grand Rapids, MI: Eerdmans, 2012), 585-600.

42 Moltmann, "European Political Theology," 12.

43 Dorothee Soelle, Against the Wind: Memoir of a Radical Christian (transl. B. Rumscheidt and M. Rumscheidt; Munich: Hoffmann and Campe, 1999), $11-15,28-29,106-107$.

44 Ibid, 28-29.

45 For some aspects of her political theology, see Dorothee Soelle, Political Theology. A Critical Reflection on Rudolf Bultmann (transl. B. Rumshceidt and M. Rumscheidt; Philadelphia, PA: Fortress, 1974).

46 Dorothee Soelle and Fulbert Steffensky, ed. Politisches Nachtgebet in Köln, Vols. 1 \& 2 (Stuttgart: Kreuz, 1969 and 1971).

47 Renate Wind, Dorothee Soelle - Mystic and Rebel: The Biography (Minneapolis, MN: Fortress Press, 2012), 57.

48 lbid, 58

49 lbid, 38

$50 \mathrm{Ibid}, 81$; Cf. Wind, Dorothee Soelle, 60.

51 Dorothee Soelle, Mysticism and Resistance (transl. B. Rumsheidt and M. Rumscheidt; Minneapolis, MN: Fortress Press, 1997), 45-55.

52 Ibid, 1-8; 77; 279-289. Cf. Sarah K. Pinnock, The Theology of Dorothee Soelle (Harrisburg, PA: Trinity International, 2003), 19-22.

53 Martin Rumscheidt, "A Calling in a Higher Sense: The Poetics of Dorothee Soelle," in The Theology of Dorothee Soelle, ed. Sarah K. Pinnock (Harrisburg, PA: Trinity International, 2003), $71-89$ (76).

54 lbid, 76.

55 Dorothee Soelle, "Thesen über die Kriterien des Theologischen Interesses an Literatur," Almanach für Literatur und Theologie 4 (1970): 206.

56 Soelle, Against the Wind, 153.

57 This is how Dirkie Smit describes Ackermann's theology. Cf. Dirkie Smit, "Simple and Straightforward? On Doing Theology," in Ragbag Theologies. Essays in Honour of Denise M. Ackermann: A Feminist Theologian of Praxis, ed. Miranda Pillay, Sorojini Nadar and Clint de Bruyns (Stellenbosch: AFRICAN SUN MeDIA, 2009), 157-176.

58 Denise M. Ackermann, "Found Wanting and Left Untried?' Confessions of a Ragbag Theologian," in Ragbag Theologies. Essays in Honour of Denise M. Ackermann: A Feminist Theologian of Praxis, ed. Miranda Pillay, Sarojini Nadar and Clint de Bruyns (Stellenbosch: AFRICAN SUN MeDIA, 2009), 267-286 (270).

59 Ibid, 270.

60 Denise M. Ackermann, After the Locusts. Letters from a Landscape of Faith (Grand Rapids, MI: Eerdmans, 2003), 24.

61 Ibid, xii.

62 Ibid, xiii.

63 John W. de Gruchy, "On Locusts and Wild Honey - Letter Writing as Doing Theology," in Ragbag Theologies. Essays in Honour of Denise M. Ackermann: A Feminist Theologian of Praxis, ed. Miranda Pillay, Sorojini Nadar and Clint de Bruyns (Stellenbosch: AFRICAN SUN MeDIA, 2009), 175-184 (175).

64 Smit, "Simple and Straightforward," 157-158.

65 De Gruchy, "Locusts and Wild Honey," 176.

$66 \mathrm{lbid}, 177$.

67 Ackermann, "'Found Wanting and Left Untried," 270.

68 lbid, 280. 
69 Denise Ackermann, "Becoming Fully Human: An Ethic of Relationship in Difference and Otherness," Journal of Theology for Southern Africa 102 (1998): 13-27. Denise Ackermann, Surprised by the Man on the Borrowed Donkey: Ordinary Blessings (Cape Town: Lux Verbi, 2014), 51-98; Ackermann, After the Locusts, 1-22.

70 Ackermann, After the Locusts, 2.

$71 \mathrm{lbid}, 3$.

72 lbid, 11.

73 Ackermann, Surprised, 15.

$74 \mathrm{lbid}, 16$.

75 Jessie Heyman, "Viola Davis Gave the Most Powerful Emmy Awards Acceptance Speech of All Time," Vogue (2 September 2015). Cited 25 July 2017. Online: https://www.vogue.com/article/viola-davisemmys-2015-acceptance-speech 


\section{HIV AND FAITH \\ Shaping the Response from Rhetoric into Transformative Social Action}

Beverley Haddad

\section{Introduction}

The HIV epidemic was a silent killer during the 1990s. Without a real understanding of the epidemic and no antiretroviral treatment available, hundreds of thousands of people died. Stigmatisation of those diagnosed HIV positive played no small part in these deaths. The faith community was understood to be a major role player in fuelling this stigma and it was not until the early 2000s that the global AIDS activist community began to work with faith actors to mitigate the epidemic. The School of Religion and Theology (now School of Religion, Philosophy and Classics) at the University of KwaZulu-Natal has been at the forefront of changing theological attitudes and beliefs that stigmatise those living with HIV. This has meant shifting attitudes and beliefs away from a moralistic individualist approach to an understanding of the unjust systemic nature of the HIV epidemic.

This essay seeks to outline the strategies implemented within the School to bring about a shift from moralistic rhetoric to transformative social action within the faith community. These strategies include the theological curriculum, the establishment of a collaborative on religion and HIV and engaging with the public realm of HIV discourse. The essay concludes with the current challenge of the high rates of infection amongst young women due largely to patterns of transactional sex with older men. It argues that now more than ever activistintellectuals are needed within the theological project to ensure that AIDS is ended by 2030.

\section{The Changing Landscape of HIV and Religion}

Towards the end of 2010, as I was driving to work, I noticed a newspaper headline on a poster attached to a lamppost in a street in Pietermaritzburg. "Jesus is HIV positive", it declared! What the newspaper article was referring to was a sermon preached by a Pentecostal pastor, Pastor Skosana, in Khayelitsha, a sprawling township in Cape Town. 
His sermon sparked an outcry with other pastors in neighbouring townships who opposed the association of Jesus with HIV. What was of interest to me in the newspaper article was not so much the outcry that the sermon caused, but rather the preacher of the sermon himself. Clearly, Pastor Skosana led one of the growing number of neo-Pentecostal groups. He understood the challenge of the HIV epidemic confronting his congregants having himself lost two sisters to AIDS-related illnesses and was prepared to be bold and quite deliberately "shocking" in order to get the message across. He did not stop there as he concluded his three-part sermon by taking an HIV test. This all took place in 2010.

What was remarkable was that ten years earlier, the words "HIV" or "AIDS" could not be mentioned in church gatherings let alone from the pulpit. Working as an assistant Anglican priest in the semi-rural area of Vulindlela outside Pietermaritzburg in the late 1990s, one could only refer to the epidemic euphemistically with church people (including church leaders) saying, "The person has been bewitched", "They have the illness", and so forth. ${ }^{1}$ It was also the time that church leaders moralised the epidemic. ${ }^{2} \mathrm{~A}$ key debate raging within HIV activist circles concerned the extent to which faith-based organisations were fuelling stigma and discrimination with anecdotal evidence suggesting that church leaders believed that AIDS was a punishment from God for "promiscuous behaviour".3 Therefore, to read of Pastor Skosana who in 2010 had found a way to speak of HIV theologically from the pulpit in a helpful and life-giving manner was encouraging.

There can be no doubt that the increased boldness of religious leaders such as Pastor Skosana in speaking about HIV from the pulpit with less retributive rhetoric was closely tied with the shifting HIV and AIDS discourse in the country as whole. HIV was no longer seen as a death sentence in quite the same way due to massive education campaigns in the early 2000s (particularly with young people) and the upscale and large roll-out of antiretroviral drugs since 2007. ${ }^{4}$ Religious leaders themselves had been drawn into prevention efforts in a concerted way and were seen as key stakeholders by bodies such as UNAIDS from the early 2000s..$^{5}$ Faith-based involvement in the HIV epidemic in Africa generally saw unprecedented growth from 2003 with the allocation of $\$ 15$ billion dollars by the United States President's Emergency Plan for AIDS Relief (PEPFAR). ${ }^{6}$ During the following decade, there was increasing response to the HIV epidemic ${ }^{7}$ by faith-based organisations, as well as increased research on the response of this sector. ${ }^{8}$

The increased boldness of religious leaders such as Pastor Skosana to speak out in a more positive way about HIV, I want to suggest, was also in part due to the theological enterprise undertaken by a variety of individuals and groups to address the unhelpful retributive theology that was fuelling the epidemic. Ecumenical organisations such as the Ecumenical Advocacy Alliance and the Ecumenical HIV and AIDS Initiative in Africa (EHAIA) ${ }^{9}$ were founded in the early 2000s and the African Network of Religious Leaders Living With and Affected by HIV and AIDS (+ANERELA now +INERELA) ${ }^{10}$ in 2006. 
Within the School of Theology (now Religion, Philosophy and Classics) at the University of KwaZulu-Natal (UKZN), various projects were initiated in response to the growing AIDS crisis in communities and amongst students at the School from the mid-1990s. These initiatives were expanded in the early 2000s as more donor funding became available. People in local communities known to academic staff were dying of AIDS-related illnesses and within the School itself, students were being sent home to their countries of origin quite literally in body bags. It became clear to academic staff, many of whom were already engaged in activist work, that the silence around HIV in religious circles needed to be broken. New ways of doing theology that stressed life rather than death were desperately needed. Personally, I feel privileged to have worked with colleagues who have taught me and challenged me in my own theological reflection as we have walked this journey together. As we have worked together on these initiatives for more than a decade, we have sought to enable theological students and researchers to see their academic work not as mere rhetoric, but as a means to action that will change people's lives in the context of HIV. These initiatives can be broadly categorised as those that targeted theological students studying at the School, those that linked the academy with communities and those that sought to influence the realm of public health. With the founding of the Collaborative for HIV and AIDS, Religion and Theology (CHART) in 2007, this three-fold focus became more deliberate and coordinated.

\section{Theological Initiatives Targeting Theological Students}

\section{Church and AIDS Postgraduate Elective Module}

As early as 2003, my colleague Philippe Denis who had been actively involved with AIDS orphans in the greater Pietermaritzburg area introduced an elective module for postgraduate students titled "Church and AIDS". The module outline stated that the outcomes of the module were to enable participants to:

- Have a basic understanding of the medical, social, economic and cultural aspects of HIV/AIDS in South Africa;

- Be able to articulate a theological response to the crisis caused by HIV/AIDS; and

- Be exposed to one organisation working with persons living with HIV and reflect on this experience. ${ }^{11}$

For the next two years, Denis coordinated the module that exposed students to the realities of HIV and AIDS and argued the case for the involvement of the church. As a requirement, students had to spend 15 hours during the semester volunteering in a non-governmental organisation that was practically responding to the HIV and AIDS epidemic. ${ }^{12}$ When I took over the coordination of the module in 2005, I continued with this approach, which had a decisive impact upon students. One student remarked at the end of the module in an 
evaluation, "[The module] has helped me to see and understand better. Before I only spoke of HIV/AIDS theoretically and speculatively, but now I can also speak about HIV/AIDS from experience." ${ }^{13}$

Over the next ten years, the module was adapted extensively to focus on the particular challenges brought about by the changing landscape of HIV and AIDS. While initially it was important to expose students to the realities of HIV through a field work placement in an organisation, it later became clear that students also needed to be challenged to do theology and to speak out theologically against stigma and discrimination. As part of the requirement of the 2007 module, they had to organise an annual worship service under the theme, "AIDS is NOT a punishment from God: Dispelling stigma and discrimination" which all theological students were encouraged to attend. New knowledge about HIV, as well as life-giving theological reflection, were put into practice as the students from the class worked on the liturgy. ${ }^{14}$

By 2008, the outcomes of the module had been expanded. It was stated in the module outline that participants will:

- Have a basic understanding of the medical, socio-economic, cultural and gender aspects of the HIV and AIDS epidemic;

- Understand the importance of the church's role in stigma and discrimination, prevention and access to treatment;

- Be able to articulate a theological response to the crisis caused by HIV and AIDS;

- Understand the importance of public policy in the epidemic;

- Reflect on personal responses to the epidemic and implications for future work; and

- Gain experience in organising a public HIV testing campaign. ${ }^{15}$

There is a clear shift here to greater engagement with the debates on HIV in the public health field, encouraging HIV testing among peers and the need for the student to reflect on how the module would impact their future work. Increasingly, government campaigns encouraged everyone to have a regular HIV test. Therefore, students were required to organise and participate in a public testing campaign held on the premises of the university with the explicit purpose of encouraging other theological students and staff to take an HIV test and thereby encourage public HIV testing by religious leaders. The exercise was also used to promote peer education and to provide practical skills for students to learn through experience how to organise a public HIV testing campaign, which they could take into their church life. As an assignment, they had to offer a personal reflection on the experience. ${ }^{16}$ For most, it was a transformational experience as many tested openly for the first time together with their peers and lecturers, offered support and encouraged others to do the same. The experience also offered opportunities for reflection on how stigma was at work amongst their peers: 
There is no doubt that the hospitality by our team members made things easy for those who wanted to come for testing but had no courage to do it. This was acknowledged by few of them as they mentioned that they were scared and worried, yet willing to come for testing. For some, it was seen from their reactions that they were scared and terrified with fear as those with light complexion easily turned red in colour! Some would come and go, but because of seeing others flocking in freely, they ended up gaining courage and got tested as well. ${ }^{17}$

Almost certainly, the public testing campaign organised by the students of the Church and HIV and AIDS module prompted and shamed the University into action. Eventually, public HIV testing campaigns were organised by the Student Health Services on campus and became regular events twice a year. As a result of public HIV testing events being mainstreamed into university life, it was felt that other training priorities needed to be addressed in the module. About that time in 2013, +INERELA initiated training courses with clergy on a new HIV prevention methodology known as SAVE. As a prevention method, SAVE attempts to address more explicitly some of the problematic aspects of the $\mathrm{ABC}$ prevention methodology and importantly also the issue of sexuality. ${ }^{18}$ For this reason, it was decided that the public HIV testing campaign be replaced with a three-day SAVE training workshop as a requirement of the module. ${ }^{19}$ In fact, all postgraduate students were encouraged to attend the training and cooperation from other staff in the School was elicited to make this possible. Against all expectations, 44 students attended the first training workshop in $2013 .{ }^{20}$ Since then, the number of participants involved in the training has had to be restricted due to financial reasons, but it continues to be an aspect of the module that is valued by the students as stated by one student who attended the training, "I will recommend that all pastors need [sic] this training in order to preserve lives." ${ }^{21}$

In an evaluation at the end of the training course by students in 2013, the following responses indicated how they planned to use the training they received:

- Organise workshops and in my sermons I will preach about HIV;

- Engage with groups in my local church and community;

- Break the silence, be strategic and share the information; and

- Locate people who are serious about getting involved and train them. ${ }^{22}$

A final comment by a student suggests how the module has moved those who attend from rhetoric into (potential) action:

I am now theologically equipped to make a sound church response to the crisis caused by HIV and AIDS. The course exposed me to many issues on HIV and AIDS through a range of HIV and AIDS activities, through seminars, symposia and a three day HIV prevention workshop (SAVE). ${ }^{23}$

This postgraduate elective module became central to the research work of postgraduate students, establishing theoretical frameworks and providing an informed research agenda. 


\section{Postgraduate Research Work on Religion and HIV}

By 2005, academic staff within various theological disciplines at the School began to supervise students interested in the intersection of religion and HIV. As a collaborative inter-disciplinary venture, a one-year special focus MTh on HIV and AIDS was offered in 2006 and through a grant from the Church of Sweden, the School was able to offer merit bursaries to ten students. ${ }^{24}$ This programme, under the leadership of Edwina Ward, was structured in such a way that students remained within their particular theological discipline, meeting all these requirements while participating in intensive modules on HIV and AIDS. Ten students undertook to take the elective discussed above in the second semester, as well as to attend a week-long HIV-intensive module prior to the start of the first semester. Cohort seminars were held throughout the first semester, while the students shaped their research work through group presentations. ${ }^{25}$ In collaboration with other colleagues, I coordinated this module which included field visits to communities, as well as theoretical classroom work. One of the outcomes was to provide the context for the shaping of their research work. ${ }^{26}$

As indicated earlier, there was increased research on the interface of religion and HIV in the years following the PEPFAR grant in 2003. Studies were carried out not only by established researchers, but also by master's and doctoral students based in various institutions in Africa, African students based in the global north and students from other parts of the world with an interest in religion and HIV in Africa. The increase of student research in African institutions was in part due to a substantial five-year grant by the Swedish Development Agency (2009-2012) for postgraduate research. The award of this grant was largely due to the success of the one-year MTh with a special focus on HIV that was piloted at UKZN in 2006. This grant enabled the establishment of the African Network of Higher Education Research in Theology, HIV and AIDS (ANHERTHA) in 2008 under the leadership of Edwina Ward. ${ }^{27}$

ANHERTHA coordinated the scholarships offered primarily to master's students from six African institutions, namely University of KwaZulu-Natal, South Africa; Stellenbosch University, South Africa; Ethiopian School of Graduate Theology, Ethiopia; Makumira University, Tanzania; St Paul's University, Kenya; and Uganda Christian University. The purpose of the scholarships was to encourage research on religion and HIV with a particular focus on Christian theology. Articles from the theses of some of the first graduates were published in a book titled A Theology of HIV E AIDS on Africa's East Coast: A Collection of Essays by Masters Students from Four African Academic Institutions. ${ }^{28}$

At UKZN, full bursaries were awarded to master's students and smaller bursaries were also offered to Honours and PhD students working in the field of religion and HIV over the fouryear funding cycle. ${ }^{29}$ As will be discussed later in the essay, the establishment of CHART 
enabled the ANHERTHA bursary holders to receive support through the collaborative efforts of their supervisors. CHART offered a carefully structured and regular seminar programme where students were able to share their research findings with one another across disciplines. ${ }^{30}$ The CHART programme supplemented the individual supervision that the students received and assisted in achieving a high throughput of graduates holding these bursaries. ${ }^{31}$

\section{Linking the Academy with Communities through Activist Research}

Alongside the pedagogical work with theological students, a body of "activist research" has emerged out of the School of Religion and Theology at UKZN. Many of the staff, including myself, regard ourselves as "activist-intellectuals" 32 and see any research on the role of religion in HIV as work that must change people's lives.

This ideological orientation is embedded within the wider theological project that developed at the School of Theology (now School of Religion, Philosophy and Classics) at UKZN in the 1980s. The Kairos Document was a "significant tool" in constructing the theological project at the School that sought to "provide forms of theological education that would equip African Christians to engage with their contexts, within a prophetic theological framework" ${ }^{33}$

As part of this task two community-based centres were established to link the academy with communities - the Institute for the Study of the Bible (ISB) in 1989 (which merged with the House of Studies for Worker Ministry in 1996 and became the Ujamaa Centre for Community Development and Research in 2004) and the Sinomlando Centre for Oral History and Memory Work in Africa in 1994.

In 2001, Sinomlando Centre for Oral History and Memory Work in Africa partnered with a Catholic non-governmental organisation, Sinosizo Home-Based Care, in a pilot study that evaluated "the impact of the memory-box methodology ${ }^{34}$ on AIDS-affected households". 35 The significance of this work with children quickly became apparent. The work expanded into a number of communities in KwaZulu-Natal with peer educators being trained to use the memory-box methodology for over a decade. Philippe Denis, the then director of the centre, together with others such as Nokhaya Makiwane and Radikobo Ntsimane saw this ongoing memory-box work in communities as an opportunity to reflect on its significance in and for the academy. There is a body of published articles that attests to the contribution they made in linking activist work with the academy. ${ }^{36}$

As early as 1995, ISB, under the Directorship of Gerald West, began working with women's groups using Contextual Bible study ${ }^{37}$ to raise "AIDS awareness". ${ }^{38}$ This focus on HIV and AIDS grew as church groups invited ISB to conduct workshops and the Worker Ministry 
project initiated a job-creation project for people living with HIV at the initiative of Mzwanzile Nunes. ${ }^{39}$ In 2002, ISB and the Worker Ministry Project established a solidarity programme for people living with HIV and began working with those living with HIV in a more sustained way. Bongi Zengele was appointed to steer this programme and she helped to facilitate the establishment of a network of support groups for people living with HIV called "Siyaphila" (We are alive).$^{40}$ West and Zengele over a number of years engaged in Contextual Bible Study work with members of these support groups. This communitybased work was an attempt to use the resources of the academy to impact community life. Bongi Zengele argues that all work that intersects religion and HIV needs to emerge out of the lived experience of those who are HIV positive. ${ }^{41}$ West and Zengele as Denis, Makiwane and Ntsimane have used their activist work in communities to significantly influence theological reflection on HIV. ${ }^{42}$

My own work, which has attempted to do the same, was prompted by the field research for my doctoral studies in Vulindlela outside Pietermaritzburg between 1996 and 1999 a period when the word HIV or AIDS was not mentioned in the community. Part of my activist work included conducting contextual Bible studies with a group of semi-literate women for nearly three years. ${ }^{43}$ My attempts to raise the question of AIDS-related deaths in the community at this time have been documented elsewhere. ${ }^{44}$ It was later, between 2004 and 2006 at the height of the ambiguous response of faith leaders to the epidemic, that I was able to return to the community and embarked on a small qualitative study with ordained male and women church leaders. The study was my attempt to understand this ambiguity and also to see if there was a qualitative difference in the response of male and female leaders. The findings of the study have been published elsewhere, ${ }^{45}$ but what is of note here is the fact that the male ordained leaders felt theologically paralysed. They understood that the answers to the "why" of the epidemic were not simple. Because their theological training and experience had always been marked by a theology of retribution - "you sow what you reap" and "if something bad has happened then you must have done something wrong" - they did not know how else to theologise and preach on the subject. Of course, in the HIV context, this kind of theology is quite literally deadly. In discussions with these leaders in safe spaces, they acknowledged that they were paralysed theologically. Therefore, one of the ways to respond to their paralysis was to offer these church leaders a short training course (conducted by field workers of the Ujamaa Centre, namely Sthembiso Zwane and Sibonelo Zuma) which, amongst other things, offered new ways of talking about HIV theologically and of communicating these reflections from the pulpit. ${ }^{46}$ This is one example of how I ensured that my research work was activist in practice and sought to change attitudes and behaviour.

Other colleagues in the School also sought to link the academy with communities in their research on HIV and AIDS. Neville Richardson together with some colleagues from the 
School and researchers from Norway embarked on a two-year project (2004-2005) in the community of Mpophomeni outside Howick in KwaZulu-Natal. ${ }^{47}$ Steve de Gruchy was a co-founder of the African Health Assets Programme (ARHAP) in 2002. ${ }^{48}$ While the work of ARHAP focused more broadly on religion and public health, ARHAP researchers, including De Gruchy, conducted a number of projects in various communities across Southern Africa with a particular focus on HIV and AIDS. ${ }^{49}$ Isabel Phiri and Sarojini Nadar, while engaged in research work on HIV and AIDS since 2002 through the Circle of Concerned African Theologians, have made a particular contribution to this body of activist research through a project in Inanda near Durban in 2008. The project sought to answer the question, "To what extent is indigenous knowledge capable of providing a critique of patriarchy as manifested in marriage and sexuality in the context of HIV and AIDS"? 50

This brief overview of the body of work on religion and HIV and AIDS that has emerged out of the activist work by intellectuals at the School of Religion, Philosophy and Classics at UKZN has both foregrounded the voices of those living with HIV and also established a research agenda for scholars working in the field of religion and HIV. The work of these activist intellectuals has also been guided and shaped by CHART, which has provided a collaborative space to guide initiatives that target theological students and link the academy with communities. CHART has also offered the opportunity to work on new initiatives that target the public realm through collaborating with international stakeholders and so impact the field of public health.

\section{Collaborating in the Public Realm}

CHART was founded in 2007 in the then School of Religion and Theology (now the School of Religion, Philosophy and Classics) by this small group of academics and activists with the financial assistance of the Church of Sweden. The impact of the work of CHART on theological students has been documented elsewhere. ${ }^{51}$ For the purpose of this essay, I want to highlight the work of CHART as it has impacted the public realm of HIV and AIDS.

"The Cartography of HIV and AIDS, Religion and Theology" was an international research project initiated in 2008 which sought firstly to compile a bibliographic database of all published literature on the interface between religion, theology and HIV and AIDS. The bibliographic database is an ongoing project of CHART, which is offered to researchers and activists throughout the world through the worldwide web. ${ }^{52}$ To date, it contains over 3,000 references and is partially annotated. A second aspect of the cartography project was to analyse critically the body of work on religion and HIV in order to understand what had been accomplished in different contexts and across an array of different religious and other disciplines. This analysis was then used to map a future research agenda. Thirdly, the cartography project was established to provide an opportunity to widen collaborative relationships and to form a coalition that straddled the academic-activist divide. The result 
of that collaborative engagement is the volume, Religion and HIV and AIDS: Charting the Terrain, which was published in $2011 .^{53}$ This landmark volume has placed the theological work of CHART and its engagement with those living with HIV within the international public realm, offering a critical position on religion and HIV. Furthermore, the online bibliographic database has enabled researchers from the medical and social science fields to broaden their perspective on the role of religion and religious stakeholders in the epidemic. This aspect of CHART's work has deliberately targeted the public realm and sought to influence the broader religion and HIV discourse. ${ }^{54}$

Another major way in which the work of CHART has sought to influence the public realm is through its engagement with stakeholders involved in the bi-annual International AIDS conferences organised by the International AIDS Society. ${ }^{55}$ The stakeholders included UNAIDS, as well as Ecumenical Agencies such as the Ecumenical Advocacy Alliance (EAA). The EAA was instrumental in organising a pre-faith conference prior to the bi-annual International AIDS Conference. As Director of CHART and with the support of colleagues, one of my roles was to network with key role players and I represented CHART on the organising committee of this pre-faith conference on a number of occasions. In 2010, I also collaborated with Gillian Paterson (supported by EAA) in the formation of an international network on Religion and HIV known as HIV, AIDS and Religion Collaborative (HARC) which was launched at the XVIII International AIDS Conference in Vienna, Austria. The HARC network was established to promote the creation of a community of academics, researchers, practitioners and religious leaders who work at the interface of religious faith and HIV and AIDS. ${ }^{56}$ It was hoped that the HARC community would support members through enriched channels of communication, expanded systems for supporting new research and the facilitation of international, interdisciplinary collaboration over existing initiatives. Unfortunately, largely due to funding constraints, HARC was disbanded in 2014.

\section{What about the Future?}

In the above discussion, I have argued that cultivating change agents requires deliberate attempts to move people from rhetoric into action. The discussion demonstrates how activistintellectuals at the School of Religion, Philosophy and Classics, UKZN, have attempted to do this on different levels - first, with the theological students under their tutelage, second, in their activist collaborative research work in communities and third, through their engagement with key stakeholders in the international HIV and AIDS community.

There can be no doubt that this activist theological project has been challenging and lifechanging for all who have been involved as we have sought to do theology and build lifegiving theological capacity. All have been moved - academics, activists, those living with HIV, even the international stakeholders with whom we have collaborated. For those of us 
engaged in the theological enterprise, the HIV epidemic has raised a number of theological questions about the nature of God, the nature of our relationships within faith communities and the nature and purpose of our work in the world, amongst others. It has fundamentally brought issues of gendered power relations, human sexuality, and health and healing onto our theological agendas. What faith communities do with these issues and the extent to which HIV positive people are the main interlocutors when attempting to answer these questions continue to challenge the church, the community and the academy.

The ongoing challenge comes in the wake of international funding for HIV initiatives drying up, leading to HIV being shifted off the global agenda and consequently off the church agenda. ${ }^{57}$ Yet, it comes at a time when the HIV epidemic is far from ended.

The rate of new HIV infections remains high among young women aged 15-24 years, with approximately 4,500 new HIV infections weekly among this group, which is double the number seen in young men. ${ }^{58}$ In its 2016 report, UNAIDS declared that "Girls and young women have to be placed at the centre of the response if the region is to end AIDS by 2030." The report argues that "these high levels of infection are driven largely by high prevalence in the community, gender inequality and inequity, traditions, and limited educational opportunities". Also driving these high levels of infection are "extremely high levels of sexual abuse and violence against female children, including underage, child and forced marriage" ${ }^{59}$ Central to this discussion in South Africa is the ongoing research that shows that many young women of 15-24 years old are having sex with older men. ${ }^{60}$ In trying to understand these high rates of new infections in young women, research over the past decade has increasingly confirmed that age-disparate relationships play an important role in HIV vulnerability. ${ }^{61}$ This is related to a number of factors, including decreased condom use, early sexual debut and limited ability to negotiate the nature of the sexual act, which often leads to coerced and forced sex, amongst others. ${ }^{62}$ With the growing body of work identifying distinct patterns of transactional sex between young women and older men, a number of initiatives have addressed the "sugar daddy" phenomenon and more recently the growth in the number of "blessers" by national and provincial governments and non-governmental organisations. ${ }^{63}$

At a workshop for health specialists held in March 2017 in Durban, the Director of CAPRISA, Salim Abdool-Karim, argued that the burden of the 1,000 new HIV infections per day in South Africa is as a result of the large number of men who do not know their HIV status and the high number of young women having sex with older men. ${ }^{64}$ His plea to older men to "Leave young women alone" was based on a large study conducted by the CAPRISA researchers between 2014 and 2015 in KwaZulu-Natal. ${ }^{65}$ This study highlighted the gendered nature of the "cycle of HIV transmission" nuancing the discussion on the role of age-disparate sex in HIV vulnerability. They found that the sexual partners of women 
under the age of 25 years were on average nearly nine years older than the women, while among women in the 25-40 age group their sexual partners were on average just a year older. $^{66}$ Through a mapping of sexual partners using the genetic sequences of the viruses from HIV blood samples, they were able to ascertain that 39\% of men aged 25-40 years were simultaneously linked to a woman under the age of 25 . While infection levels are markedly different between women and men in the 15-24 age group, they are almost equal in the 25-40 age group. Abdool-Karim et al. thus conclude that, because HIV transmission is most likely to occur from high to low prevalence, these men must have been infected by their partner aged 25-40 and they then in turn infect women under the age of $25 .{ }^{67}$ The researchers expect that as these younger women grow older, the cycle of HIV transmission would continue, unless there are concerted efforts by all stakeholders to intervene and break this cycle of transmission.

Our work as religious activist-intellectuals is, therefore, far from over and clearly we are faced with new theological challenges. Much rests on the question of how we theologise sexuality and prevention messages to young people in the face of growing unemployment and the commodification of sex, which is exacerbated by the digital age. Underlying this conundrum is the question of how we deal theologically with the intersection of gender, culture, sexuality, economics and race in a way that is appropriate to our particular contexts. Both these questions cannot overlook sexual identity issues, particularly in the HIV context where men who have sex with men and transgendered people have also been identified as key populations vulnerable to HIV. ${ }^{68} \mathrm{New}$ and creative ways of doing theology are needed in this current context. Our theological work, while not ignoring the lingering retributive messages, needs to be quite deliberate in its attempt to confront these new patterns of sexual behaviour.

\section{Conclusion}

In conclusion, let me return to Pastor Skosana. In many ways, Skosana demonstrates the shifts the HIV epidemic forced on the theological enterprise during the mid-2000s. Clearly, his theological loci had changed over the twenty-four years of his ministry as he found new ways of interpreting the Bible in his HIV and AIDS context. ${ }^{69}$ Perhaps this significantly came about, because he was forced to see and understand the epidemic through the eyes of his two sisters who died of AIDS-related illnesses. His theology thus directly engaged with those who were HIV positive, forcing him to change his attitude and behaviour and thereby becoming a change agent. The same must be true in the current, ever-changing HIV context. Theologians and church leaders need to face the reality of age-disparate sex by directly engaging with those involved in this practice in their churches and acting theologically, practically and prophetically. 
This is a complex task, because it is not just about gendered power relations, but also about broader economic issues facing South Africa. Theological initiatives such as those that have emerged at the School of Religion, Philosophy and Classics of UKZN need to provide guidance and focus more directly on the intersection of economics and sexuality. In some measure, this has begun to take place. The Church and HIV and AIDS postgraduate module, now team-taught, has since 2014 deliberately focused on issues of sexuality by reflecting on "indecent" and "improper" theology. ${ }^{70}$ Activist research on the "sugar daddy" phenomenon has taken place through a collaboration between the contextual Bible study work of the Ujamaa Centre and myself. ${ }^{71}$ But this needs to be further developed in communities by engaging with a wider range of participants, including church leaders and the men and women in churches involved in age-disparate sex. There is also a need for deeper collaboration with key stakeholders in the public realm who are engaged in research and activism around this issue.

In the changing HIV and AIDS landscape, where new infections continue to rise amongst young African women, we cannot afford to allow our response to lapse back into rhetoric. Global activists continue to work towards ending AIDS by $2030^{72}$ and now more than ever the faith community needs to act to ensure that we, too, are part of this movement for change. Now more than ever we need to ensure that we continue to do theology, speak prophetically into the public realm and work in collaboration with those who are already HIV positive and with those who are most vulnerable to HIV infection.

\section{Bibliography}

Allison, Simon. "South Africa's AIDS Programme under Threat as International Funds Dry up." Cited 23 March 2017. Online: https://www.theguardian.com/global-development/2015/dec/01/ south-africa-aids-programme-under-threat-international-funds-dry-up

AVERT. "Funding for HIV and AIDS." No Pages. Cited 14 March 2017. Online: http://www.avert.org/ professionals/hiv-around-world/global-response/funding\#footnote6_i8c150z

Campbell, Catherine; Skovdal, Morten and Gibbs, Andy. "Creating Social Spaces to Tackle AIDS-related Stigma: Reviewing the Role of Church Groups in Sub-Saharan Africa." AIDS Behaviour 15 (2011): 1204-1219. https://doi.org/10.1007/s10461-010-9766-0

Cullinan, Kerry and Pillay, Kamcilla. "\#AIDS 2016: New AIDS Taxes Possible, as Donor Funds Dry up." Cited 23 March 2017. Online: http://www.iol.co.za/news/special-features/aids2016-new-aids-taxespossible-as-donor-funds-dry-up-2046757

Denis, Philippe. "Oral History in the Context of AIDS: Memory Boxes as a Way of Building up Resilience in Orphans and Traumatised Children in KwaZulu-Natal." Journal of Constructive Theology 7/1 (July 2001): 17-30.

Denis, Philippe. "Sharing Family Stories in Times of AIDS." Missionalia 29/2 (August 2001): 258-281.

Denis, Philippe. "Memory Work and Resilience." Pages 1-18 in Never Too Small to Remember: Memory Work and Resilience in Times of AIDS. Edited by Philippe Denis. Pietermaritzburg: Cluster, 2005.

Denis, Philippe. "Are Zulu Children Allowed to Ask Questions? Silence, Death and Memory in the Time of AIDS." Pages 583-590 in Zulu Identities: Being Zulu, Past and Present. Edited by Benedict Carton, Jabulani Sithole and John Laband. Pietermaritzburg: University of KwaZulu-Natal Press, 2008.

Denis, Philippe. "The Church's Impact on HIV Prevention and Mitigation in South Africa: Reflections of a Historian." Journal of Theology for Southern Africa 134 (2009): 66-81. 
Denis, Philippe. "Memory Work with Children Affected by HIV/AIDS in South Africa." Pages 159-165 in The Oxford Handbook of Oral History. Edited by Donald A. Ritchie. Oxford University Press, 2011.

Denis, Philippe. "HIV/AIDS and Religion in Sub-Saharan Africa: An Emerging Field of Enquiry." Archives de Sciences Sociales de Religion 164 (Oct-Dec 2013): 43-58. https://doi.org/10.4000/assr.25399

Denis, Philippe and Makiwane, Nokhaya. "Stories of Love, Pain and Courage: AIDS Orphans and Memory Boxes." Oral History $31 / 2$ (2003): 66-74.

De Oliveira, Tulio; Kharsany, Ayesha B.M.; Gräf, Tiago; Cawood, Cherie; Khanyile, David; Grobler, Anneke; Puren, Adrian; Madurai, Savathree; Baxter, Cheryl; Abdool Karim, Quarraisha and Abdool Karim, Salim S. "Transmission Networks and Risk of HIV Infection in KwaZulu-Natal, South Africa: A Community-wide Phylogenetic Study." The Lancet 4 (January 2017): e41-e50. Cited 5 May 2017. Online: https://doi.org/10.10 16/S2352-3018(16)30186-2

Fray, Beverly M. "Review of Beverley Haddad, ed., Religion and HIV and AIDS: Charting the Terrain." Journal of the Association of Nurses in AIDS Care 23/3 (2012): 268-271. https://doi.org/10.1016/ i.jana.2012.01.007

Haddad, Beverley. "African Women's Theologies of Survival: Intersecting Faith, Feminisms and Development." Ph.D Thesis, University of Natal, 2000.

Haddad, Beverley. "Reflections on the Church and HIV/AIDS: South Africa." Theology Today 62 (2005): 29-37. https://doi.org/10.1177/004057360506200104

Haddad, Beverley. "Faith Resources and Sites as Critical to Participatory Learning with Rural KwaZulu-Natal Women." Journal of Feminist Studies in Religion 21/1 (Spring 2006): 135-154. https://doi.org/10.2979/ FSR.2006.22.1.135

Haddad, Beverley. "'We Pray but We Cannot Heal': Theological Challenges Posed by the HIV/AIDS Crisis." Journal of Theology for Southern Africa 125 (2006): 80-90.

Haddad, Beverley. "Surviving the HIV and AIDS Epidemic in South Africa: Women Living and Dying, Theologising and Being Theologised." Journal of Theology for Southern Africa 131 (2008): 47-57.

Haddad, Beverley. "Charting the Terrain: Religion in a Globalised HIV World." Journal of Theology for Southern Africa 138 (2010): 71-90.

Haddad, Beverley, ed. Religion and HIV and AIDS: Charting the Terrain. Pietermaritzburg: University of KwaZulu-Natal Press, 2011.

Haddad, Beverley and Olivier, Jill. "The Potentials and Perils of Partnership: Christian Religious Entities and Collaborative Stakeholders Responding to HIV in Kenya, Malawi and the DRC." Cape Town: ARHAP, 2008. Cited 5 May 2017. Online: www.irhap.uct.ac.za

Olivier, Jill. "Religion and Policy on HIV and AIDS: A Rapidly Shifting Landscape." Pages 81-104 in Religion and HIV and AIDS: Charting the Terrain. Edited by Beverley Haddad. Pietermaritzburg: University of KwaZulu-Natal Press, 2011.

Olivier, Jill. "Hoist by Our Own Petard: Backing Slowly out of Religion and Development Advocacy." HTS Teologiese Studies/Theological Studies 72(4): a3564. Cited 5 May 2017. Online: https://doi.org/ 10.4102/hts.v72i4.3564

Phiri, Isabel and Najar, Sarojini. "Going through the Fire with Eyes Wide Open: African Women's Perspective on Indigenous Knowledge, Patriarchy and Sexuality." Journal for the Study of Religion 2/2 (2009): 5-22.

Phiri, Isabel and Najar, Sarojini. "Cutting Cultural Corners: Ritual Male Circumcision as a Health Asset for HIV Prevention? An African Feminist Perspective." Pages 139-154 in Living on the Edge: Essays in Honour of Steve de Gruchy Activist and Theologian. Edited by James R. Cochrane, Elias Bongmba, Isabel Phiri and Des van der Water. Pietermaritzburg: Cluster, 2012.

Richardson, Neville, ed. Broken Bodies and Healing Communities: The Challenge of HIV and AIDS in the South African Context. Pietermaritzburg: Cluster, 2009.

Schmid, Barbara; Thomas, Elizabeth; Olivier, Jill and Cochrane, James R. "The Contribution of Religious Entities to Health in Sub-Saharan Africa." Cape Town: ARHAP, 2008. Cited 5 May 2017. Online: www.irhap. uct.ac.za

South African National AIDS Council (SANAC). "HIV \& AIDS and STI Strategic Plan for South Africa 2007-2011." No Pages. Cited 14 March 2017. Online: http://www.kznonline.gov.za/hivaids/strategicplans/khomanani_HIV_plan.pdf

UNAIDS. "Fast Track: Ending the AIDS Epidemic by 2030." Cited 27 March 2017. Online: http://www.unaids.org/ en/resources/documents/2014/JC2686_WAD2014report

UNAIDS. "HIV Prevention among Key Populations." Cited 27 March 2017. Online: http://www.unaids.org/en/ resources/presscentre/featurestories/2016/november/20161121_keypops 
UNAIDS. "Prevention GAP Report 2016." Cited 5 May 2017. Online: http://www.unaids.org/sites/default/ files/media_asset/2016-prevention-gap-report_en.pdf

Ward, Edwina and Gary Leonard, ed. A Theology of HIV\& AIDS on Africa's East Coast: A Collection of Essays by Masters Students from Four African Academic Institutions. Uppsala: Swedish Institute of Mission Research, 2008.

West, Gerald. "Reading the Bible in the Light of HIV/AIDS in South Africa." Ecumenical Review 55/4 (2003): 335-344. https://doi.org/10.1111/i.1758-6623.2003.tb00468.x

West, Gerald. "The Poetry of Job as a Resource for the Articulation of Embodied Lament in the Context of HIV and AIDS in South Africa." Pages 195-21 4 in Lamentations in Ancient and Contemporary Cultural Contexts. Edited by Nancy C. Lee and Carleen Mandolfo. Atlanta, GA: Society of Biblical Literature, 2008.

West, Gerald. "Newsprint Theology: Bible in the Context of HIV and AIDS." Pages 161-186 in Out of Place: Doing Theology on the Crosscultural Brink. Edited by Jione Havea and Clive Pearson. London: Equinox, 2011.

West, Gerald. "The School of Religion, Philosophy and Classics: Doing Contextual Theology in Africa in the University of KwaZulu-Natal." Pages 919-926 in Handbook of Theological Education in Africa. Edited by Isabel Apawo Phiri and Dietrich Werner. Pietermaritzburg: Cluster, 2013.

West, Gerald. "Between Text and Trauma: Reading Job with People Living with HIV." Pages 209-230 in Bible Through the Lens of Trauma. Edited by Elizabeth C. Boase and Christopher G. Frechette. Atlanta, GA: SBL, 2016. https://doi.org/10.2307/j.ctt1h 1 htfd. 15

West, Gerald. The Stolen Bible: From Tool of Imperialism to African Icon. Pietermaritzburg: Cluster, 2016. https://doi.org/10.1163/9789004322783

West, Gerald and Haddad, Beverley. "Boaz as 'Sugar Daddy': Re-reading Ruth in the Context of HIV." Journal of Theology for Southern Africa 155 (2016): 137-156.

West, Gerald and Zengele, Bongi. "Reading Job 'Positively' in the Context of HIV/AIDS in South Africa." Concilium 4 (2004): 112-124.

West, Gerald and Zengele, Bongi. "The Medicine of God's Word: What People Living with HIV and AIDS Want (and Get) from the Bible." Journal of Theology for Southern Africa 125 (2006): 51-63.

West, Gerald and Zengele, Bongi. "Time for Jesus to Wake up." Pages 97-105 in Stilling the Storm: Contemporary Responses to Mark 4.35-5.1. Edited by John Vincent. Brandford Forum: Deo, 2011.

World Health Organization. "World Health Report 2004: Changing History." Geneva: World Health Organization. 2004. Cited 5 May 20175 November 2015. Online: http://www.who.int/whr/2004/en/

Zengele, Bongi. "Religion and Policy on HIV and AIDS: A Rapidly Shifting Landscape." Pages 105-107 in Religion and HIV and AIDS: Charting the Terrain. Edited by Beverley Haddad. Pietermaritzburg: University of KwaZulu-Natal Press, 2011.

\section{Endnotes}

1 Beverley Haddad, "Reflections on the Church and HIV/AIDS: South Africa," Theology Today 62 (2005): 29-37 (30-32).

2 Philippe Denis, "The Church's Impact on HIV Prevention and Mitigation in South Africa. Reflections of a Historian," Journal of Theology for Southern Africa 134 (2009): 66-81.

3 For a more detailed discussion on the debate of the role of church leaders, see Beverley Haddad, "'We Pray but We Cannot Heal': Theological Challenges Posed by the HIV/AIDS Crisis," Journal of Theology for Southern Africa 125 (2006): 80-90.

4 South African National AIDS Council (SANAC), "HIV \& AIDS and STI Strategic Plan for South Africa 2007-2011," n.p. Cited 14 March 2017. Online: http://www.kznonline.gov.za/hivaids/strategic-plans/ khomanani_HIV_plan.pdf

5 Jill Olivier, "Religion and Policy on HIV and AIDS: A Rapidly Shifting Landscape," in Religion and HIV and AIDS: Charting the Terrain, ed. Beverley Haddad (Pietermaritzburg: University of KwaZulu-Natal Press, 2011), $81-104$.

6 AVERT, "Funding for HIV AND AIDS," n.p. Cited 14 March 2017. Online: http://www.avert.org/ professionals/hiv-around-world/global-response/funding\#footnote6_i8c150z

7 WHO, "World Health Report 2004: Changing History" (Geneva: World Health Organization, 2004$), 46$. Cited 5 November 2015. Online: http://www.who.int/whr/2004/en/; Olivier, "Religion and Policy," 84. 
8 See Barbara Schmid, Elizabeth Thomas, Jill Olivier and James R. Cochrane, "The Contribution of Religious Entities to Health in Sub-Saharan Africa" (Cape Town: ARHAP, 2008). Cited 5 November 2015. Online: www.irhap.uct.ac.za. Beverley Haddad and Jill Olivier, "The Potentials and Perils of Partnership: Christian Religious Entities and Collaborative Stakeholders Responding to HIV in Kenya, Malawi and the DRC" (Cape Town: ARHAP, 2008). Cited 5 November 2015. Online: www.irhap.uct.ac.za

9 History of EHAIA. Cited 5 November 2015. Online: https://www.oikoumene.org/en/what-we-do/ehaia

10 History of INERELA+. Cited 5 November 2015. Online: https://inerela.org/

11 Unpublished Module Outline, Church and AIDS, Theo 730 and 830 (2004).

12 lbid.

13 Unpublished Student Evaluation of Module, Church and HIV/AIDS Theo 730 and 830 (2005).

14 Unpublished Module Outline, Church and AIDS, Theo 730 and 830 (2007).

15 Unpublished Module Outline, Church and AIDS, Theo 730 and 830 (2008).

16 Unpublished Module Outline, Church and AIDS, Theo 730 and 830 (2010).

17 Unpublished Personal Reflection by Participating Student (2010).

18 For a more detailed description of the SAVE Methodology, see the following website. Cited 5 November 2015. Online: http://inerela.org/resources/save-toolkit/

19 Unpublished Module Outline, Church and AIDS, Theo 730 and 830 (2013).

20 Unpublished CHART Annual Report (2013).

21 Unpublished Student Evaluation of SAVE Training (2013).

22 Ibid.

23 Unpublished Student Evaluation of Module, Church and HIV and AIDS, Theo 730 and 830 (2014).

24 Unpublished Evaluation Report Commissioned by the Church of Sweden on the "Masters Degree in Theology and HIV/AIDS Project 19539" (June 2011 ).

25 Unpublished Module Outline, Contemporary Issues in Christianity: HIV/AIDS Special Focus Theo 816 (2006).

26 Ibid.

27 Unpublished Evaluation Report Commissioned by the Church of Sweden on the "Masters Degree in Theology and HIV/AIDS Project 19539" (June 2011).

28 Edwina Ward and Gary Leonard, ed. A Theology of HIV\& AIDS on Africa's East Coast: A Collection of Essays by Masters Students from Four African Academic Institutions (Uppsala: Swedish Institute of Mission Research, 2008).

29 Over the four-year period, a total of twenty-four bursaries were awarded to master's students, ten to Honours students and eight to PhD students. See ANHERTHA Unpublished Final Report (2012).

30 See Unpublished CHART Annual Reports (2009-2012).

31 All students who received ANHERTHA bursaries, with the exception of two PhD students have graduated. See Unpublished UKZN Graduation Booklets (2010-2016).

32 See Beverley Haddad, "African Women's Theologies of Survival: Intersecting Faith, Feminisms and Development" (PhD Thesis, University of Natal, 2000), 188-192.

33 Gerald West, "The School of Religion, Philosophy and Classics: Doing Contextual Theology in Africa in the University of KwaZulu-Natal," in Handbook of Theological Education in Africa, ed. Isabel Apawo Phiri and Dietrich Werner (Pietermaritzburg: Cluster, 2013), 919-926 (920).

34 For a description and history of this methodology, see Philippe Denis, "Sharing Family Stories in Times of AIDS," Missionalia 29/2 (August 2001): 258-281.

35 Philippe Denis, "Memory Work and Resilience," in Never Too Small to Remember: Memory Work and Resilience in Times of AIDS, ed. Philippe Denis (Pietermaritzburg: Cluster, 2005), 1 - 18 (5).

36 Philippe Denis, "Oral History in the Context of AIDS: Memory Boxes as a Way of Building up Resilience in Orphans and Traumatised Children in KwaZulu-Natal," Journal of Constructive Theology 7/1 (July 2001): 17-30. Philippe Denis, "Sharing Family Stories in Times of AIDS. Philippe Denis and Nokhaya Makiwane, "Stories of Love, Pain and Courage: AIDS Orphans and Memory Boxes," Oral History 31/2 (2003): 66-74. Philippe Denis, ed. Never Too Small to Remember. Philippe Denis, "Are Zulu Children Allowed to Ask Questions? Silence, Death and Memory in the Time of AIDS," in Zulu Identities: Being Zulu, Past and Present, ed. Benedict Carton, Jabulani Sithole and John Laband (Pietermaritzburg: University of KwaZulu-Natal Press, 2008), 583-590. Philippe Denis, "Memory Work with Children Affected by HIV/AIDS in South Africa," in The Oxford Handbook of Oral History, ed. Donald A. Ritchie (Oxford University Press, 201 1), 159-165. 
37 For a detailed description of this methodology, see Gerald West, "Newsprint Theology: Bible in the Context of HIV and AIDS," in Out of Place: Doing Theology on the Crosscultural Brink, ed. Jione Havea and Clive Pearson (London: Equinox, 2011), 161-186.

38 See Umtata Women's Group, "God our Loving Father: Bible Studies on AIDS," Unpublished (n.d.), ISB Unpublished Annual Reports (1995 and 1998).

39 See ISB Unpublished Annual Report (1997).

40 For a detailed description of these groups and the purpose of establishing this network see, Gerald West, "Reading the Bible in the Light of HIV/AIDS in South Africa," Ecumenical Review 55/4 (2003): 335-344.

41 Bongi Zengele, "Religion and Policy on HIV and AIDS: A Rapidly Shifting Landscape," in Religion and HIV and AIDS: Charting the Terrain, ed. Beverley Haddad (Pietermaritzburg: University of KwaZulu Natal Press, $2011), 105-107$ (105).

42 See Gerald West, "Reading the Bible in the Light of HIV/AIDS in South Africa." Gerald West and Bongi Zengele, "Reading Job 'Positively in the Context of HIV/AIDS in South Africa," Concilium 4 (2004): 112-124. Gerald West and Bongi Zengele, "The Medicine of God's Word: What People Living with HIV and AIDS Want (and Get) from the Bible," Journal of Theology for Southern Africa 125 (2006): 51 -63. Gerald West, "The Poetry of Job as a Resource for the Articulation of Embodied Lament in the Context of HIV and AIDS in South Africa," in Lamentations in Ancient and Contemporary Cultural Contexts, ed. Nancy C. Lee and Carleen Mandolfo (Atlanta, GA: Society of Biblical Literature, 2008), 195-214. Gerald West and Bongi Zengele, "Time for Jesus to Wake up," in Stilling the Storm: Contemporary Responses to Mark 4.35-5.1, ed. John Vincent (Brandford Forum: Deo, 2011), 97-105. Gerald West, "Newsprint Theology." Gerald West, "Between Text and Trauma: Reading Job with People Living with HIV," in Bible through the Lens of Trauma, ed. Elizabeth C. Boase and Christopher G. Frechette (Atlanta, GA: SBL, 2016), 209-230.

43 Beverley Haddad, "African Women's Theologies of Survival," 293-324.

44 Beverley Haddad, "Faith Resources and Sites as Critical to Participatory Learning with Rural KwaZulu-Natal Women," Journal of Feminist Studies in Religion 21/1 (Spring 2006): 135-154.

45 Beverley Haddad, "We Pray but We Cannot Heal': Theological Challenges Posed by the HIV/AIDS Crisis". "Surviving the HIV and AIDS Epidemic in South Africa: Women Living and Dying, Theologising and Being Theologised," Journal of Theology for Southern Africa 131 (2008): 47-57.

46 For a detailed outline of the programme of this training course, see Unpublished Annual Report, "Theology and Development Programme, School of Religion and Theology," (2006).

47 For details and outcomes of this project, see Neville Richardson, ed. Broken Bodies and Healing Communities: The Challenge of HIV and AIDS in the South African Context (Pietermaritzburg: Cluster, 2009).

48 For a history of the African Religious Health Assets Programme, see the website Cited 5 November 2015. Online: http://www.irhap.uct.ac.za/irhap/about/history

49 A detailed list of research reports. Online: http://www.irhap.uct.ac.za/irhap/research

50 Isabel Phiri and Sarojini Nadar, "Going through the Fire with Eyes Wide Open: African Women's Perspective on Indigenous Knowledge, Patriarchy and Sexuality," Journal for the Study of Religion 2/2 (2009): 5-22. Isabel Phiri and Sarojini Nadar, "Cutting Cultural Corners: Ritual Male Circumcision as a Health Asset for HIV Prevention? An African Feminist Perspective," in Living on the Edge: Essays in Honour of Steve de Gruchy Activist and Theologian, ed. James Cochrane et al. (Pietermaritzburg: Cluster, 2012), 139-154.

51 Beverley Haddad, "Charting the Terrain: Religion in a Globalised HIV World," Journal of Theology for Southern Africa 138 (2010): 71-90.

52 Online: www.chart.ukzn.ac.za

53 Beverley Haddad, ed., Religion and HIV and AIDS: Charting the Terrain (Pietermaritzburg: University of KwaZulu-Natal Press, 2011 ).

54 See, for example, C. Campbell, M. Skovdal and A. Gibbs, "Creating Social Spaces to Tackle AIDSrelated Stigma: Reviewing the Role of Church Groups in Sub-Saharan Africa," AIDS Behaviour 15 (2011): 1204-1219. Beverly M. Fray, "Review of Beverley Haddad, ed., Religion and HIV and AIDS," Journal of the Association of Nurses in AIDS Care 23/ 3 (2012): 268-271. Philippe Denis, "HIV/AIDS and Religion in Sub-Saharan Africa: An Emerging Field of Enquiry," Archives de Sciences Sociales de Religion 164 (Oct-Dec 2013): 43-58. Jill Olivier, "Hoist by Our Own Petard: Backing Slowly out of Religion and Development Advocacy," HTS Teologiese Studies/ Theological Studies 72(4): a3564.

Cited 5 November 2015. Online: http://dx.doi.org/10.4102/hts.v72i4.3564

55 For further information on the International AIDS Society, see website: https://www.iasociety.org 
56 Unpublished flyer used at launch of HARC, Vienna, Austria, 2010.

57 Kerry Cullinan and Kamcilla Pillay, "\#AIDS 2016: New AIDS Taxes Possible, as Donor Funds Dry up." Cited 23 March 2017. Online: http://www.iol.co.za/news/special-features/aids2016-new-aids-taxespossible-as-donor-funds-dry-up-2046757. Simon Allison, "South Africa's AIDS Programme under Threat as International Funds Dry up." Cited 23 March 2017. Online: https://www.theguardian.com/globaldevelopment/2015/dec/01/south-africa-aids-programme-under-threat-international-funds-dry-up

58 UNAIDS, "Prevention GAP Report 2016." Cited 23 March 2017. Online: http://www.unaids.org/sites/ default/files/media_asset/2016-prevention-gap-report_en.pdf

59 Ibid.

60 For a detailed discussion of this research, see Gerald West and Beverley Haddad, "Boaz as 'Sugar Daddy': Re-reading Ruth in the Context of HIV," Journal of Theology for Southern Africa 155 (2016): 137-156 (137-147).

$61 \mathrm{lbid}, 142$.

$62 \mathrm{lbid}, 143$

63 "Sugar Daddy Campaign," n.p. Cited 27 May 2015. Online: http://www.kznhealth.gov.za/sugardaddy.htm. "New Campaign Calls on South Africa's Women and Girls to 'Zazi'." Cited 27 May 2015. Online: http://www.zazi.org.za. "Fighting the Curse of 'Blessers'," n.p. Cited 9 July 2016. Online: http://www.bbc. com/news/blogs-trending-36342561. "South Africa Launches National Campaign for Young Women and Adolescent Girls," n.p. Cited 23 March 2017. Online: http://www.unaids.org/en/resources/presscentre/ featurestories/2016/june/20160624_south-africa

64 Sinenhlanhla Ngubane and Lihle Sosibo, "Still 1000 New HIV Infections Daily in SA," n.p. Cited 15 March 2017. Online: http://ndaba-online.ukzn.ac.za/UkzndabaNewsletter/Vol5-Issue6

65 Tulio de Oliveira et al., "Transmission Networks and Risk of HIV Infection in KwaZulu-Natal, South Africa: A Community-wide Phylogenetic Study," The Lancet 4 (January 2017): e4 1-e50. Cited 15 March 2017. Online: http://dx.doi.org/10.1016/S2352-3018(16)30186-2

$66 \mathrm{lbid}, \mathrm{e} 47$.

67 lbid.

68 UNAIDS, "HIV Prevention among Key Populations." Cited 27 March 2017. Online: http://www.unaids. org/en/resources/presscentre/featurestories/2016/november/20161121_keypops

69 For a discussion of Pastor Skosana's use of the Bible, see Gerald West, The Stolen Bible: From Tool of Imperialism to African Icon (Pietermaritzburg: Cluster, 2016), 559.

70 See Unpublished Module Outlines "Church and HIV and AIDS," Theo 730 and 830 (2014-2016).

71 West and Haddad, "Boaz as 'Sugar Daddy'," 150-155.

72 See UNAIDS, "Fast Track: Ending the AIDS Epidemic by 2030." Cited 27 March 2017.

Online: http://www.unaids.org/sites/default/files/media_asset/JC2686_WAD2014report_en.pdf 


\section{THE COLOUR OF CHANGE Identity Matters, Christian Faith and Resistance in the HIV and AIDS Pandemic

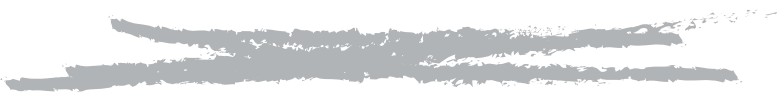

Cheryl B. Anderson

\section{The Importance of Identity Matters in the HIV and AIDS Pandemic}

Globally, the reduction in new HIV infections and AIDS-related deaths is encouraging. In 2016, new infections among adults declined by an estimated 11 percent since 2010 and AIDS-related deaths had fallen by 48 percent since the peak in $2005 .{ }^{1}$ In the United States and South Africa, however, two population groups continue to be disproportionately impacted by the virus - heterosexual women and bisexual or homosexual men (or men who have sex with men, 'MSM', a term that refers to behaviour rather than a self-identified sexual orientation). The purpose of this essay is to identify why these two groups remain heavily impacted by the pandemic and to propose responses from a Christian perspective that will help to resist and transform these negative dynamics. To start, reviewing the relevant statistics will be helpful in showing the depth of the pandemic's impact on heterosexual women and MSM.

In South Africa, the HIV prevalence is now estimated at between 22 percent and 48 percent among men who have sex with men and, although the rates vary geographically in the three major cities, Johannesburg, Cape Town and Durban, rates are reported to have risen by more than 10 percent. ${ }^{2}$ Similarly, in the United States, "young black MSM (aged 13-24) are the most severely affected subpopulation of MSM and they accounted for more new diagnoses than any other subgroup by race/ethnicity, age, or sex." ${ }^{3}$ In fact, it has been estimated that if their current infection rates persist one in two black MSM in the United States will be diagnosed with HIV in their lifetime. ${ }^{4}$ Nearly 60 percent of all African Americans diagnosed with HIV in 2015 were gay or bisexual men. ${ }^{5}$

The disproportionate impact of HIV on women has been recognised for some time. Generally, women constitute more than half of all people living with HIV and AIDS-related illnesses remain the leading cause of death for women of reproductive age (aged 15-44). ${ }^{6}$ 
For women, the primary mode of transmission is heterosexual sex. Recently, more attention is being paid to the high toll the disease takes on young women and adolescent girls.

Young women (10-24 years), and adolescent girls (10-19 years) in particular, account for a disproportionate number of new HIV infections. In fact, young women are twice as likely to acquire HIV as their male counterparts. In 2015, 20\% of new HIV infections among adults were among women aged $15-24$ despite this group only accounting for $11 \%$ of the global adult population. This equates to some 7,500 young women across the world acquiring HIV every week. ${ }^{7}$

Of course, it is shocking to learn that about 7,500 young women around the world are infected with the virus each week. However, it is even more shocking to learn that there are almost 2,000 young women (aged 15-24) who are infected each week in South Africa alone, and this rate is two and a half times that among males of the same age. ${ }^{8}$ In the United States, African American women are disproportionately impacted by HIV, too. Among all women in the United States, black women account for the largest share of new HIV diagnoses (about 4,500 or $60 \%$ in 2015) and the rate of new diagnoses among black women $(26.2 \%)$ is 16 times the rate among white women and nearly five times the rate among Latinas. ${ }^{9}$ Furthermore, newly infected African American women are more likely to be younger than newly infected white women. ${ }^{10}$ As for the modes of transmission, women were most likely to be infected through heterosexual sex ( $84 \%$ of new infections in 2010), followed by injection drug use (16\%); and the rate of infection from heterosexual sex for black women was higher at 87 percent. ${ }^{11}$

Clearly, vulnerability to HIV infection increases for certain segments of the human population based on two aspects of identity - gender and sexual orientation; and these two groups are heterosexual women and gay or bisexual men (MSM). Another aspect of identity, however, needs to be mentioned in the context of this pandemic - race/ethnicity. HIV is primarily a disease of African peoples. In 2015, almost 66 percent of the global total of new infections was in sub-Saharan Africa. ${ }^{12}$ In the same way, African Americans, although they represent 12 percent of the United States population, account for more new diagnoses (44\%), more people estimated to be living with HIV (40\%) and more HIV-related deaths (44\%) than any other racial/ethnic group in the United States. ${ }^{13}$ Consequently, those who are most at risk of infection in the United States and South Africa are not just women and men who have sex with men, but black heterosexual women and black MSM, and this fact demonstrates the importance of identity matters in the age of AIDS. These groups marked by race, gender and sexual orientation are more likely to be infected than other groups and it is worthwhile to consider why such vulnerability exists.

To understand where we are now in the HIV and AIDS pandemic, we must consider its beginning. According to the British theorist Jeffrey Weeks, the advent of AIDS precipitated a "moral panic" because it "was seen as a disease of the marginal and promiscuous - two categories that merged in the national psyche to produce a threat of fearful proportions". ${ }^{14}$ 
He argues further that the threat of "marginalized sexualities was accompanied by a fear of other marginalized communities both within and without the country, those of black people" ${ }^{15}$ Taken together, Weeks finds that AIDS came to represent "the inevitable end-product of permissiveness and of rapid social dislocation". ${ }^{16}$ Since HIV is sexually transmitted, it triggers a specific type of moral panic, a "sexual (or sex) panic" where "the cultural imagination becomes obsessed with anxieties about what this evil sexuality will do to warp society and future generations". ${ }^{17}$ In the grip of a sex panic, a return is demanded to conservative political and religious practices "that distrust sexual impulses, condone double standards between men and women, and despise same-sex relationships".18

In 2003, President George W. Bush launched the President's Emergency Plan for AIDS Relief (PEPFAR) that provided funds to combat the pandemic internationally and its requirements reflect those conservative political and religious practices that are re-affirmed in a sex panic. One third of the allocated funds were for abstinence-only and faithfulnessin-marriage programmes and no attention was given to same-sex transmission. PEPFAR's prevention strategy, known by the acronym "ABC", emphasises abstinence before marriage, faithfulness in marriage and if necessary condom usage. In spite of the notable successes of the PEPFAR programme, this essay's premise is that its underlying conservative Christian stances are unable to counter (and may contribute to) the continuing infection rates for black heterosexual women and black gay and bisexual men in South Africa and the United States. A change, therefore, is needed in the theological and biblical understanding of the pandemic and its prevention. Since those who are disproportionately affected are black, that needed change does indeed have a colour and any prevention strategies should take the realities of black people into account.

\section{Exploring the Intersections of Christianity, Identity and HIV}

The "ABC" prevention strategy supported by conservative Christians was mandatory in countries that received PEPFAR funding and it was voluntarily adopted by many African American congregations in the United States. For conservative Christians, "ABC" affirmed their ideal for a Christian couple - heterosexual, married, monogamous and procreative. The problem though is that the dictates of "ABC" are not consistent with the realities of these communities. For example, abstinence before marriage is advocated, but 15,000 teenaged pupils in South Africa became pregnant in 2015. ${ }^{19}$ In that same year, more than 40 percent of the babies born in the United States were born to unmarried women and the rate was even higher for African American babies. ${ }^{20}$ Similarly, marriage is encouraged and faithfulness in marriage is thought to prevent new infections, but wives who are faithful can be infected by their husbands who are not faithful. In fact, marriage is a HIV-risk factor for women globally. ${ }^{21}$ Condoms are mentioned as part of the PEPFAR prevention strategy, but in some circumstances faith-based groups dropped references to the " $\mathrm{C}$ " and advocated 
abstinence and faithfulness exclusively. To make matters worse, some men are unwilling to use condoms and a recent study in South Africa found that condom use had dropped between 2008 and 2012. ${ }^{22}$ Lastly, the "ABC" prevention strategy does not address the needs of male same-sex partners and tends to reinforce their marginalisation. For these reasons, "ABC" is not a prevention method that will result in zero new infections for either country.

The emphasis of the PEPFAR guidelines was to encourage personal "behavior change" in the form of abstinence and faithfulness as the way to confront HIV. Its focus on "self-help" and "individual responsibility for disease prevention" paralleled the conservative American policies of the 1990s that ushered in a "weakening of state welfare and the expansion of global free-market capitalism" ${ }^{23}$ As Lydia Boyd has found in her study of PEPFAR in Kampala, Uganda, it presumes "a Western cultural orientation to health that places value on the virtues of physical autonomy and independence", but in Uganda "where health has long been considered in part a function of the social and spiritual relationships one has with others, a message of self-reliance as the best pathway to healthiness has its limits." ${ }^{24}$ Given the statistics cited earlier in this section, "behavior changes" were limited in the United States and South Africa or at a minimum not as broad as theorised.

If behavioural changes have not occurred to prevent new infections, it means that persons are still engaging in behaviours that put them at risk of infection. Why? One reason is that persons do not function in a vacuum and their choices are often circumscribed by their social and economic environments. Dr Paul Farmer who works with poor communities in Haiti finds that their high rate of disease is related to social, political and economic inequities such as poverty and gender disparity. As a result, he concludes that these precipitating inequities constitute "structural violence" and the disease prevalence seen in these communities is the direct result of that violence. ${ }^{25}$ From Farmer's perspective, we must consider the degree to which "social forces ranging from poverty to racism become embodied in individual experience" ${ }^{26}$ The significance of Farmer's work is that it shifts the focus from individual behaviour to the structural systems that influence such behaviour. Although conservative Christians have tended to support a focus on individual "behavior change" as expressed in the PEPFAR guidelines, we know that HIV disproportionately impacts those who are marginalised by race/ethnicity, gender, sexual orientation and class. As is often observed, HIV tracks the "fault lines of society" indicating those who are affected by these social and cultural disparities.

One of those disparities, gender is worth considering in detail. Although "gender" may be thought to cover women only, it functions to distinguish between men and women, and therefore it pertains to both. Furthermore, in the process of our discussion, we will make the connection between gender construction and the condemnation of homosexuality. To begin, "gender" refers to the oppositional characteristics attributed to men and women 
respectively. As explained in a handbook on HIV and AIDS, "the dominant ideology for femininity in most societies dictates that women should be subordinate, dependent, and passive". Additionally, "the key virtues of the ideal woman include virginity (if she is not married), chastity, motherhood, moral superiority, and obedience to men". It follows then that women are encouraged to be "sexually ignorant, sexually passive, and sexually innocent". ${ }^{27}$ In contrast, "the dominant ideology of masculinity characterizes men as independent, dominant, invulnerable aggressors, and providers whose key virtues are strength, virility, and courage". It follows also that men are encouraged to be "sexually knowledgeable, sexually aggressive and sexually experienced". 28

These gender differences have meant that on the one hand, younger women are not knowledgeable about sexual health, "have little control over when, where or how sexual activity occurs, including the use of condoms". Their sexual inexperience makes them less likely to have sexually transmitted diseases and, therefore, more attractive to older men. ${ }^{29}$ On the other hand, men are assumed to know about sexual matters so they may not seek out appropriate information even if they do not know it; their sexually aggressive nature can be expressed in risk-taking and having multiple sexual partners, yet those same sexual experiences increase their risk of contracting HIV. ${ }^{30}$

Taken together, these dynamics present a pattern, which shows that women are submissive to their men (who themselves have multiple partners). They are unable to negotiate safer sex practices and they are most likely to contract HIV from their own husbands or partners. For example, in one aspect of Melissa Browning's work on marriage and HIV in Tanzania, nine of the twelve women she interviewed were married and faithful to their husbands, but they had contracted HIV from them. To illustrate that her findings were not unusual, Browning referred to a UNAIDS and UNDP study issued in 2001 which "indicated that 80 percent of all infected married women contracted the virus from their partners" ${ }^{31}$ As seen here, the traditional gender distinctions described earlier - dominant male and submissive female are the gender inequities to which Farmer refers in his work. These gender inequities, along with poverty, are examples of systemic violence, which contribute to the disease prevalence in marginalised communities, and in this case particularly in women, according to Farmer. While that dynamic still functions to disadvantage women, other recent studies on gender and HIV in sub-Saharan countries paint a more complex picture.

Mark Hunter in his study of gender and HIV in South Africa (KwaZulu-Natal) recognises that Farmer's analysis of inequities as structural violence does explain some of the drivers of the HIV pandemic. Nevertheless, he argues that analysis must go beyond "the politicaleconomic context" to examine "the materiality of everyday sex". ${ }^{22}$ From his perspective, it is important to examine the ways that relationships among the marginalised have been affected by "chronic unemployment and capital-led globalization".33 Hunter finds that 
difficult economic times have fundamentally changed the ways in which intimacy works and he describes those economic circumstances as affecting both employment and marriage rates:

Joblessness and labor market casualization engendered an extraordinary social gap between a shrinking group of mostly core male workers and the rest of the population. Of particular importance, women's rapid movement into the labor force, while at first partially driven by industrial employment, has not been matched by employment growth in recent years. Along with reduced marriage rates, these labor market changes represent a generational shift that can be crudely summarized as follows: from men mostly earning a living and supporting a wife to men and women making a living in multifarious ways. ${ }^{34}$

Hunter's analysis shows that "making a living" in marginalised South African communities contributes to both men and women having multiple concurrent partners. For men, widespread unemployment means that marriage rates are lower and as a result, a man can have multiple partners for longer periods of his life and he will still be respected in his community. ${ }^{35}$ As for women, they now challenge the old "double standard" and claim their own ability to have multiple partners. Furthermore, their own unemployment or underemployment means that they seek additional financial support from older men, Sugar Daddies who serve as their "ministers of finance, transport and entertainment". ${ }^{36}$ It would be easy to dismiss men and women having multiple partners as expressions of promiscuity, but that would result in misunderstanding why this phenomenon is occurring.

Sanyu Mojola's analysis of these gender dynamics focused on Kenya (Kisumu, Nyanza Province), but she rightfully contends that her observations apply to sub-Saharan Africa and the United States. She argues that in both settings, globalised consumer economies have marketed consumer goods, including toiletries, soaps and perfumes, as necessities for modern women and the process has turned them into "consuming women". ${ }^{37}$ In their contexts of great economic disparities, young women are told that they need these products to be beautiful and attract a husband, but their own financial means are limited. Mojola finds that "continual consumption" of these products "requires partners with continual access to income" and it "makes intimate relationships with older, employed men, who have higher HIV-prevalence rates, more attractive than those with unemployed young men, who have relatively low rates".38

For Mojola, intimacy and money have become intertwined through the promotion of consumer goods in ways that "make modernity and romance synonymous with consumption" ${ }^{39}$ Interestingly, the women who strove most to display the symbols of modernity were not the ones from the poorest backgrounds; they were women with secondary or college educations but who still needed additional income. It should not be surprising then that young women (under 30) in Kenya who lived in middle-wealth households have the highest rates of HIV and "women living in the poorest households ... have the lowest rates 
of HIV".40 Mojola convincingly argues that the school system itself brings together girls from different backgrounds and introduces them to consumer goods such as cosmetics, which quickly become a necessity. ${ }^{41}$ As a result, the process of growing up for too many girls is one of becoming "consuming women", and living out that identity makes them vulnerable to HIV infections.

The analyses of Mark Hunter and Sanyu Mojola help us to understand why infection rates are so high for young women. However, their work also indicates why the conservative Christian approach of "ABC" is ineffective in preventing new infections for this same population segment. Mojola notes that knowledge of abstinence was widespread, but it was not practised widely by young men and women because of the various benefits of having a relationship: ${ }^{42}$

In sum, abstinence was not just about not having sex; rather, the meanings and expectations attached to sex - love, provision, and masculinity - suggest why knowledge about abstinence for prevention was widespread, but rarely put into practice. Trying to encourage abstinence among youth would rapidly fail if the social underpinning of sex was not taken into account. Asking a young man to abstain would be asking him essentially to not have a girlfriend, to not prove his manhood, and to not prove his love. Asking a young woman to abstain would be asking her to be satisfied with what she had, to cut off her access to gifts and money for her needs, and to limit or postpone her transition to marriage, since for many, a sexual relationship was a prelude to marriage. ${ }^{43}$

Along with abstinence, the conservative Christian approach to prevention requires partners to be faithful in marriage. Without a doubt, faithfulness is a laudable goal but, as already discussed, faithful wives can be infected by their unfaithful husbands. Furthermore, one of the drivers of the pandemic in young women is intergenerational transactional sex, that is, younger women having sex with older men in exchange for financial benefits. In South Africa, the cycle of transmission has been described as follows:

A long-term study of age-disparate sex and HIV risk for young women took place between 2002 to 2012 in South Africa, where a third of sexually active adolescent girls will experience a relationship with a man at least five years older than them. The study found a cycle of transmission, whereby high HIV prevalence in young women was driven by sex with older men (on average 8.7 years older) who themselves had female partners with HIV, many of whom had acquired HIV as young women. ${ }^{44}$

Under these circumstances - where a partner may be HIV positive at the time of marriage or become positive during the marriage - a commitment to faithfulness alone is an inadequate method of prevention.

Lastly, correct condom usage can be a means of HIV prevention, but they are not used consistently. Hunter observes that "one common reason for the non-use of condoms in South Africa - as elsewhere - is that dominant masculinities promote risk-taking and pleasure at all costs" and that attitude is best exemplified by the expression, "You can't eat a sweetie with its wrapper on". ${ }^{45}$ At the same time, Hunter finds that women prefer not to 
use condoms if they feel that they are in love with their partner. Hunter concludes that, "condomless sex can signal and be felt as love. It can differentiate main from secondary lovers, open up a relationship to the prospect of permanence, provide greater intimacy and pleasure, and increase the man's obligation to support his girlfriend." ${ }^{46}$ In this mix of motivations, the use of condoms for the prevention of HIV infection is simply not a primary concern.

Even though some of the motivations discussed here seem counterproductive, they do fit a pattern. Both young men and women are trying to replicate as much as possible traditional gendered expectations in the "materiality of everyday sex", as Hunter has noted. In settings where unemployment and underemployment are rife, marriage rates decrease, but the patriarchal nuclear family remains the desired norm. The ideal husband would "make a living" and he would financially support his wife and children. High rates of unemployment, however, mean that the pool of men who can actually fulfil that role decreases. On the one hand, if a woman cannot be sure that she will have that ideal husband on whom she can be dependent as tradition dictates, she can still create a family by having children and receiving financial support from multiple men. On the other hand, if a man does not earn enough to support a family, he can still "prove" his masculinity by providing financially through smaller amounts (probably to more than one woman). Most important, he can demonstrate masculinity by being sexually experienced and sexually aggressive, which includes "being in control of sexual interactions", "having multiple partners, particularly high-risk partners such as commercial sex workers, and engaging in unprotected sex". ${ }^{47}$ Moreover, the gender norm for masculinity has "an underlying belief that men 'need' multiple sexual partners". 48 As a result, even those men who are able to support a family and who are married might have multiple sex partners. Unfortunately, in the context of the AIDS pandemic, these behaviours of both men and women as they live up to patriarchal gender ideals contribute to the spread of the disease.

\section{Masculine Identity, Violence and the HIV/AIDS Pandemic}

Arguably, violence is the most destructive trait for masculinity given the role it plays in spreading HIV. That violent characteristic has been described in the following way: "men are also often expected to display dominant, sometimes violent, behavior toward women and toward men perceived to be weak and effeminate". ${ }^{49}$ The relationship between the disproportionate HIV infection rates for women and gender-based violence has been recognised. Notably, in a recent UNAIDS study, it was found that "in places with high HIV prevalence, women who experience intimate partner violence are 50\% more likely to acquire HIV than women who do not" ${ }^{50}$ Gender-based violence, only one aspect of which is intimate partner violence, works to keep in place traditional hierarchies of dominant men and subordinate women. As women have gained rights in the democratic modern 
nation, men have sometimes taken it upon themselves "to discipline" women so they remain in their traditional places. Within intimate relationships, therefore, "controlling one's girlfriend with violence [can be] positioned here as almost a duty, a way to straighten out a morally crooked society." ${ }^{51}$

Men, however, have not felt constrained "to discipline" only their girlfriends. To the contrary, they have taken it upon themselves to monitor women in general - especially regarding their attire. In 2007, in an area of Durban, South Africa, a woman was stripped naked for defying a local ban against women wearing trousers - an article assumed to be men's clothing. ${ }^{52}$ Similarly, women have been penalised by groups of men for wearing short skirts ("miniskirts"). ${ }^{53}$ Women's miniskirts have also been controversial in Uganda and the reason for the objections range from their revealing nature and its association with the commodification of $\operatorname{sex}^{54}$ to their representing female autonomy and the new ability of women to access resources independently and without marriage. ${ }^{55}$ The collective effect of such disciplining of women, however, is to re-enforce through their attire the subordinate status of women and their appropriate roles in the culture.

Simultaneous to these restrictive efforts concerning attire were legal efforts to impede the implementation of women's sexual and reproductive health rights in Uganda. ${ }^{56}$ The Ugandan scholar Sylvia Tamale is very aware of the circumstances under which these measures were taken:

The rolling back of sexual and reproductive rights in Uganda emerges against a backdrop of difficult times and declining socio-economic indicators. Unprecedented rates of unemployment, belowaverage wages, high taxes, an extremely high cost of living, and the poor state of health care translate into an agitated, distressed, and angry population. History teaches us that in periods of turmoil, when governments are called to account, they routinely look for 'red herrings' to try to deflect the pressure. They make defenseless social groups the targets of state persecution, in this case women and sexual minorities. ${ }^{57}$

Tamale understands that the backlash against sexual and reproductive rights in Uganda was the result of "the state provid[ing] a platform for Christian and Muslim fundamentalists to preach essentialist 'natural law' doctrines that promote male dominance, female subordination, and heteronormativity".58

Tamale's words written in 2016 resonate with those written by Gayle Rubin in 1984. In her influential article "Thinking Sex: Notes for a Radical Theory of the Politics of Sexuality", Rubin argues that issues of sexuality can become a "diversion" from more pressing societal problems:

The time has come to think about sex. To some, sexuality may seem to be an unimportant topic, a frivolous diversion from the more critical problems of poverty, war, disease, racism, famine, or nuclear annihilation. But it is precisely at times such as these, when we live with the possibility of unthinkable destruction, that people are likely to become dangerously crazy about sexuality. 
Contemporary conflicts over sexual values and erotic conduct have much in common with the religious disputes of earlier centuries. They acquire immense symbolic weight. Disputes over sexual behavior often become the vehicles for displacing social anxieties, and discharging their attendant emotional intensity. Consequently, sexuality should be treated with special respect in times of great social stress. ${ }^{59}$

In this article, Rubin connects the work of British scholars such as Jeffrey Weeks on moral panics to the work on sexual panics being done in the United States. ${ }^{60}$ Combining the two traditions means that the "diversion" Rubin describes is an aspect of a sex panic. Again, writing in 1984, Rubin already recognised that the purpose of such a moral panic was "to coerce people into normality" and she rightly anticipated that AIDS would have "far reaching consequences for sexuality in general and homosexuality in particular".61

This analysis of sex panics by Rubin and Tamale indeed applies to the current context in the United States. Their analysis puts in context the current attacks on women's sexual and reproductive health rights in the United States through efforts to defund Planned Parenthood ${ }^{62}$ as well as the assertion of religious liberty rights to fight same-sex marriages. ${ }^{63}$ These efforts against women and sexual minorities need to be seen as a diversion from issues such as national economic inequality, climate change, insecure access to health care and a crumbling national infrastructure, to name a few of our continuing problems. Likewise in South Africa, the rates of violence against women are high and the statistics are well known. ${ }^{64}$ According to Hunter, "one estimate is that a third of reported rapes involve gang rape." ${ }^{65}$ Furthermore, he finds a relationship between these rapes and changing gender norms:

This increase [in gang rapes] is consistent with an unmooring of gender norms at a time when many men failed to find work and marry. Women's move into the labor force and the virtual ending of the 'patriarchal bargain' centered on marriage made male-female relationships more contested, and gang rape is linked to these contestations in complex ways. ${ }^{66}$

Hate crimes, specifically against lesbians, occur and in one report, an activist is quoted as saying that "the notion that women do not need men for either economic support or sexual pleasures is one that is deeply threatening to entrenched patriarchal values". ${ }^{67}$ Again, these actions to re-enforce patriarchal values are taking place in a country that has ongoing issues of governmental effectiveness, service delivery, land distribution, income inequality and so forth, as Rubin and Tamale theorise would happen in a sex panic.

It is important to remember that these forms of male violence against women and sexual minorities are not an anomaly. As mentioned earlier, "men are also often expected to display dominant, sometimes violent, behavior toward women and toward men perceived to be weak or effeminate. ${ }^{68}$ In this way, violence can be used by men to make sure that women remain subordinate (not dominant), men remain dominant (not subordinate) and heteronormative attractions (men with women and women with men) remain unchallenged. 
It is worth noting here then that questions of gender and sexual orientation are connected in a patriarchal ideology. As biblical scholar Ken Stone has written, "it has long been argued by anthropologists of gender that women, certain constructions of gender, and negative attitudes toward homosexuality are linked in many (though perhaps not all) cultures." ${ }^{69}$ With the sex panics of today taking place in the context of the AIDS pandemic, it is predictable that the groups to become the "diversions" would be women and homosexual men - the two groups that are disproportionately impacted by the disease.

Understanding sex panics can teach us several lessons about gender and sexual orientation in patriarchal and heteronormative systems located in the age of AIDS. First, the fate of heterosexual women is tied to the fate of homosexual men - both are outside of the male heterosexual "norm". The fact that both the Ugandan anti-homosexuality law and their anti-pornography law (the "miniskirt" bill) were passed in 2014 demonstrates that connection - both groups were being "coerced into normality" ${ }^{70}$ Consequently, violence against heterosexual women is related to violence against LGBTQ persons and violence against LGBTQ persons is related to violence against heterosexual women. It follows then that efforts to affirm the dignity of women must be accompanied by efforts to affirm the dignity of LGBTQ persons.

Second, the tendency in the midst of a sex panic is to advocate a return to traditional patriarchal values but, as discussed earlier, it is trying to live up to those norms in times of increased economic disparities that have resulted in the increased vulnerability of both men and women to HIV infection. Rather than attempting to re-create traditional gender distinctions (which may not be possible anyway), there should be a process of "resocialization" towards "redemptive masculinities" where men "aim to promote positive masculine virtues and attributes that could be utilized in preventive and caring strategies to contain the pandemic". ${ }^{71}$

Finally, sex panics can teach us not to be diverted by the conservative and emotional rhetoric around gender identity and sexual orientation issues. As some scholars have written somewhat facetiously, "If you're panicking, you're not thinking." ${ }^{2}$ Instead, attention should be paid to addressing the underlying economic and social issues of the times. Christians then would not focus only on upholding patriarchal patterns of gender and sexuality; rather, we would work on ameliorating the underlying political and economic circumstances that some would have us ignore, but that harm so many of the marginalised.

\section{A Different Christian Perspective - Effective HIV Prevention as Resistance}

We must take seriously the fact that aspects of identity such as race, gender, sexual orientation and class matter if we are to find ways to effectively prevent new HIV infections. From the previous discussion, we have seen that those who are disproportionately impacted by the 
virus are African or of African descent (race), female (gender), bisexual or homosexual (sexual orientation) and from economically challenged circumstances (class). However, the approach to prevention that is acceptable to conservative Christians has been "ABC". That approach focuses primarily on men and women abstaining from sex until married and then being faithful to their partner once married. It is an approach that upholds the patriarchal and heteronormative pattern of a male-headed household that is sometimes difficult for black men and women to create in current economic systems. I have even argued here that attempting to live up to traditional gender roles under these trying economic circumstances has actually increased the likelihood of contracting the virus for both men and women. Consequently, for some time, I have wondered why black Christians in the United States and South Africa have not called for a different Christian response - one that would actually prevent new infections in our heavily impacted communities.

I received the answer to that question in an unexpected way - when I was teaching a multiracial group of Christian students just before their final year of secondary school. I reported the incident in the opening paragraph of my book Ancient Laws and Contemporary Controversies and it is worth quoting here in its entirety:

I had them do an exercise, the purpose of which was to encourage them, as people of faith, to read the biblical text carefully and ask questions about the messages communicated. We read the Ten Commandments, and I pointed out how slavery was condoned, and we read Judges 19, a particularly heinous story about the gang rape of a woman, and I showed them how one of the underlying messages of the text is that it is better for a woman to be raped than a man. My goal was to get them to see that they already had a sense of who God is and how God is at work in the world that can help them to evaluate problematic biblical texts. For one African American student in the class, the exercise was a total failure. At one point, she had had enough, and she blurted out, 'This is the Word of God. If it says slavery is okay, slavery is okay. If it says rape is okay, rape is okay. ${ }^{173}$

I had expected that her identity as an African American and as a female would prompt her to resonate with the kinds of questions I raised - but I was wrong. I realised that her identity as a Christian came before her identities of race or gender.

From this experience, I learned that if there was an identity that embodied "the" Christian perspective, it was not black and it was not female. I remembered Audre Lorde's work on the mythical norm as among other things white, male, heterosexual and affluent. ${ }^{74}$ It was readily apparent to me that this norm was the embodiment of the Christian perspective and it was not black (white), not female (male), not homosexual (heterosexual) and not poor (affluent). Herein lies the problem - those who determine the Christian response to the AIDS pandemic are not those most affected by it and those who are most affected by it are not those who determine the Christian response. In order to effectively prevent new HIV infections, a different Christian response is needed and it must be one that takes into account the perspectives and realities of black women and men and with differing sexual orientations. 
Generally speaking, we think that the way a biblical text has been interpreted traditionally is the only way that a text can be interpreted. As a biblical scholar, however, I know this is not the case. Rather than relying on Gen 3:14-16 to mandate dominant/subordinate relationships between men and women, there are Gen 1:26-27 and Eph 5:21-33, both of which portray a more mutual relationship. Usually, abstinence before marriage is required, but there is the Song of Songs that celebrates erotic love and the partners are not married. Instead of insisting that "the sin" of Sodom was homosexuality, we could turn to Ezekiel 16:49 which reads, "This was the sin of your sister Sodom: she and her daughters had pride, excess of food, and prosperous ease, but did not aid the poor and needy" (NRSV). This is certainly not an exhaustive list of the different biblical texts that could be used; they are only representative of the other biblical texts that could be used to construct a different Christian response to the HIV and AIDS pandemic.

Basically, the conservative evangelical ethos that has shaped the Christian response to the pandemic is not the only one that can be shaped. As Sylvia Tamale has accurately noted in a recent article, "religion need not always align itself with vested interests and dominant groups":

Indeed, liberation theology has been used to effect transformative change. .. In Africa, however, as elsewhere in the past, religion is increasingly becoming a haven for conservatives and reactionaries seeking to mask structural oppression by deflecting attention to other matters. ${ }^{75}$

A traditional Christian approach that "coerces people into normality" ultimately must be resisted. Its result is having almost 2,000 young women in South Africa become infected with HIV each week and hearing the projection in the United States that at current rates of infection, one in two black gay or bisexual men (MSM) will be diagnosed with HIV in their lifetime. Under these circumstances, an effective Christian approach to HIV prevention means recognising that identities matter.

\section{Conclusion}

Analyses of the HIV and AIDS pandemic demonstrate the importance of particular aspects of identity such as race, gender, sexual orientation, and class, and they show how these aspects can increase vulnerability to the disease. Yet, as argued in this essay, the approach to HIV prevention supported by conservative Christians is "Abstain, Be Faithful and Condomize" which seeks only individualistic behavioural change, and it considers neither these multiple identities, nor the complex everyday realities of those who live at the intersections of these multiple identities. Furthermore, "ABC" upholds the traditional and heteronormative pattern of the male-headed household and, as scholars Mark Hunter and Sanyu Mojola cited in this essay have found, can be said to constitute an attempt to uphold traditional gender norms for men and women that have resulted in increased vulnerability for black populations. 
A transformative social action initiative is very much needed to develop and implement HIV prevention strategies that are more effective than "ABC". However, to be successful, such an initiative would need to instruct in two different ways: In the first instance, our communities need to be encouraged to consider the realities of their lives as shaped by their multiple and intersecting identities. Secondly, communities should be helped to understand how Christian understandings traditionally have not considered those same realities. This is the kind of teaching, as an integral part of social action, that will allow truly effective HIV strategies to emerge.

\section{Bibliography}

Anderson, Cheryl B. Ancient Laws and Contemporary Controversies: The Need for Inclusive Biblical Interpretation. New York: Oxford University Press, 2009. https://doi.org/10.1093/acprof:oso/9780 195305500.001.0001

AVERT. "HIV and AIDS in South Africa." No Pages. Cited 20 July 2017. Online: https://www.avert.org/ professionals/hiv-around-world/sub-saharan-africa/south-africa

AVERT. "Women and Girls, HIV and AIDS." No Pages. Cited 20 July 2017. Online: https://www.avert.org/ professionals/hiv-social-issues/key-affected-populations/women

BBC. "South Africa Mini-skirt March in Protest." No Pages. Cited 24 July 2017. Online: http://www.bbc.com/ news/world-africa-17078304

Boyd, Lydia. Preaching Prevention: Born-again Christianity and the Moral Politics of AIDS in Uganda. Athens, $\mathrm{OH}$ : Ohio University Press, 2015.

Browning, Melissa. Risky Marriage: HIV and Intimate Relationships in Tanzania. Lanham, MD: Lexington Books, 2014

Card, Josefina J.; Amarillas, Angela; Conner, Alana; Dull Akers, Diana; Solomon, Julie and DiClemente, Ralph J. The Complete HIV/AIDS Teaching Kit. New York: Springer Publishing Co., 2007.

CDC. Fact Sheet: HIV among Gay and Bisexual Men." No Pages. Cited 20 July 2017. Online: https://www.cdc.gov/ nchhstp/newsroom/docs/factsheets/cdc-msm-508.pdf

CDC. "HIV among African Americans." No Pages. Cited 21 July 2017. Online: https://www.cdc.gov/hiv/group/ racialethnic/africanamericans/index.html

CDC. "Press Release: Lifetime Risk of HIV Diagnosis." No Pages. Cited 20 July 2017. Online: https://www.cdc. gov/nchhstp/newsroom/2016/croi-press-release-risk.html

CDC. "Unmarried Childbearing." No Pages. Cited 21 July 2017. Online: https://www.cdc.gov/nchs/fastats/ unmarried-childbearing.htm

Chitando, Ezra and Chirongoma, Sophie. "Introduction." Pages 1-28 in Redemptive Masculinities: Men, HIV and Religion. Edited by Ezra Chitando and Sophie Chirongoma. Geneva: World Council of Churches Publications, 2012.

EWN (Eyewitness News). "SA Teen Pregnancy Rate Raises Alarm." No Pages. Cited 21 July 2017 Online: http://ewn.co.za/2017/03/13/sa-teen-pregnancy-rate-raises-alarm

Fahs, Breanne; Dudy, Mary L. and Stage, Sarah. "Introduction - Villains and Victims: Excavating the Moral Panics of Sexuality." Pages 1-22 in The Moral Panics of Sexuality. Edited by Breanne Fahs, Mary L. Dudy and Sarah Stage. New York: Palgrave Macmillan, 2013. https://doi.org/10.1057/9781137353177_1

Farmer, Paul. AIDS and Accusation: Haiti and the Geography of Blame. Berkeley, CA: University of California Press, 1992.

Farmer, Paul; Connors, Margaret and Simmons, Janie, ed. Women, Poverty and AIDS: Sex, Drugs, and Structural Violence. 2nd ed. Monroe, ME: Common Courage Press, 2011.

Gouws, Amanda. "Public Outrage and Hashtags Won't Slow South Africa's Shocking Rates of Violence against Women." Quartz Africa. No Pages. Cited 24 July 2017. Online: https://qz.com/992704/karabomokoenas-murder-like-anene-booysen-and-reeva-steenkamp-wont-stop-south-africas-gender-violence/

Herdt, Gilbert. "Introduction: Moral Panics, Sexual Rights, and Cultural Anger." Pages 1-46 in Moral Panics, Sex Panics: Fear and the Fight over Sexual Rights. Edited by Gilbert Herdt. New York: New York University Press, 2009. 
Hirsch, Jennifer S.; Wardlow, Holly; Smith, Daniel J., Phinney, Harriett; Parikh, Shanti and Nathanson, Constance A. The Secret: Love, Marriage, and HIV. Nashville, TN: Vanderbilt University Press, 2009.

HIV.gov. "Global HIV/AIDS Epidemic." No Pages. Cited 20 July 2017. Online: https://www.hiv.gov/hiv-basics/ overview/data-and-trends/global-statistics

Hunter, Mark. Love in the Time of AIDS: Inequality, Gender, and Rights in South Africa. Bloomington, IN: Indiana University Press, 2010.

Lorde, Audre. Sister Outsider: Essays and Speeches. Berkeley, CA: Crossing Press, 1984/2007.

Mojola, Sanyu A. Love, Money, and HIV: Becoming a Modern African Woman in the Age of AIDS. Oakland, CA: University of California Press, 2014. https://doi.org/10.1525/california/9780520280939.001.0001

Moore, Erin. "What the Miniskirt Reveals: Sex Panics and Seductive Economies in Urban Uganda." Unpublished paper presented at the Program of African Studies, Northwestern University. Evanston, IL. April 26, 2017.

NPR. "In Religious Freedom Debate, 2 American Values Clash." No Pages. Cited 24 July 2017. Online: http://www.npr.org/2017/02/28/517092031/in-religious-freedom-debate-2-american-values-clash

Rollingstone. "The War on Planned Parenthood." No Pages. Cited 24 July 2017. Online: http://www.rolling stone.com/politics/news/the-war-on-planned-parenthood-20160406

Rubin, Gayle S. "Thinking Sex: Notes for a Radical Theory of the Politics of Sexuality." Pages 3-44 in Lesbian and Gay Studies Reader. Edited by A. Habelove, M.A. Barale and D. Halperin. London: Routledge, 1993.

Smith, Lydia. "Corrective Rape: The Homophobic Fallout of Post-apartheid South Africa." The Telegraph. No Pages. Cited 24 July 2017. Online: http://www.telegraph.co.uk/women/womens-life/1 1608361/ Corrective-rape-The-homophobic-fallout-of-post-apartheid-South-Africa.html

Stone, Ken. "The Hermeneutics of Abomination: On Gay Men, Canaanites and Biblical Interpretation." Biblical Theology Bulletin 27/2 (Summer 1997): 36-41. https://doi.org/10.1177/014610799702700202

Tamale, Sylvia. "Crossing the Bright Red Line: The Abuse of Culture and Religion to Violate Women's Sexual and Reproductive Health Rights in Uganda." Pages 144-158 in Women and Girls Rising: Progress and Resistance around the World. Edited by Ellen Chesler and Terry McGovern. New York: Routledge, 2016.

The Kaiser Family Foundation. "Black Americans and HIV: The Basics." No Pages. Cited 20 July 2017. Online: http://www.kff.org/hivaids/fact-sheet/black-americans-and-hivaids-the-basics/

The Kaiser Family Foundation. "Women and HIV/AIDS in the United States." No Pages. Cited 20 July 2017. Online: http://www.kff.org/hivaids/fact-sheet/women-and-hivaids-in-the-united-states/

UNAIDS. "Fact Sheet: Latest Statistics on the Status of the AIDS Epidemic." No Pages. Cited 20 July 2017. Online: http://www.unaids.org/en/resources/fact-sheet

UNAIDS. "South Africa Launches National Campaign for Young Women and Adolescent Girls." No Pages. Cited 20 July 2017. Online: http://www.unaids.org/en/resources/presscentre/featurestories/2016/june/ 20160624 south-africa

UNAIDS. "When Women Lead, Change Happens." No Pages. Cited 24 July 2017. Online: http://www.unaids. org/sites/default/files/media_asset/when-women-lead-change-happens_en.pdf

Uzodike, Ufo Okeke and Isike, Christopher. "Towards a Theoretical and Cultural Analysis of Dangerous Masculinities in Contemporary Africa: Can We Reinvent African Patriarchies to Curb HIV and AIDS." Pages 31-53 in Redemptive Masculinities: Men, HIV and Religion. Edited by Ezra Chitando and Sophie Chirongoma. Geneva: World Council of Churches Publications, 2012.

Weeks, Jeffrey. Sex, Politics, and Society: The Regulations of Sexuality since 1800. 3rd ed. London: Routledge, 2012.

Wyrod, Robert. AIDS and Masculinity in the African City: Privilege, Inequality, and Modern Manhood. Oakland, CA: University of California Press, 2016. https://doi.org/10.1525/california/9780520286689.001.0001

\section{Endnotes}

1 UNAIDS, "Fact Sheet: Latest Statistics on the Status of the AIDS Epidemic," n.p. Cited 20 July 2017. Online: http://www.unaids.org/en/resources/fact-sheet

2 AVERT, "HIV and AIDS in South Africa," n.p. Cited 20 July 2017. Online: https://www.avert.org/professionals/ hiv-around-world/sub-saharan-africa/south-africa

3 CDC, "Fact Sheet: HIV among Gay and Bisexual Men," n.p. Cited 20 July 2017. Online: https://www.cdc.gov/ nchhstp/newsroom/docs/factsheets/cdc-msm-508.pdf. CDC is an abbreviation for Centers for Disease Control and Prevention. 
4 CDC, "Press Release: Lifetime Risk of HIV Diagnosis," n.p. Cited 20 July 2017. Online: https://www.cdc.gov/ nchhstp/newsroom/2016/croi-press-release-risk.html

5 CDC, "HIV among African Americans," n.p. Cited 21 July 2017. Online: https://www.cdc.gov/hiv/group/ racialethnic/africanamericans/index.html

6 AVERT, "Women and Girls, HIV and AIDS," n.p. Cited 20 July 2017. Online: https://www.avert.org/ professionals/hiv-social-issues/key-affected-populations/women

7 Ibid.

8 UNAIDS, "South Africa Launches National Campaign for Young Women and Adolescent Girls," n.p. Cited 20 July 2017. Online: http://www.unaids.org/en/resources/presscentre/featurestories/2016/june/ 20160624 south-africa

9 The Kaiser Family Foundation, "Black Americans and HIV: The Basics," n.p. Cited 20 July 2017. Online: http://www.kff.org/hivaids/fact-sheet/black-americans-and-hivaids-the-basics/

10 Ibid.

11 lbid.

12 HIV.gov., "Global HIV/AIDS Epidemic," n.p. Cited 20 July 2017. Online: https://www.hiv.gov/hiv-basics/ overview/data-and-trends/global-statistics

13 The Kaiser Family Foundation, "Black Americans and HIV: The Basics," n.p.

14 Jeffrey Weeks, Sex, Politics, and Society: The Regulations of Sexuality since 1800. 3rd ed. (London: Routledge, 2012), 382.

15 lbid.

16 Ibid.

17 Gilbert Herdt, "Introduction: Moral Panics, Sexual Rights, and Cultural Anger," in Moral Panics, Sex Panics: Fear and the Fight over Sexual Rights, ed. Gilbert Herdt (New York: New York University Press, 2009), 5.

18 Breanne Fahs, Mary L. Dudy, and Sarah Stage, "Introduction - Villains and Victims: Excavating the Moral Panics of Sexuality," in The Moral Panics of Sexuality, ed. Breanne Fahs, Mary L. Dudy, and Sarah Stage (New York: Palgrave Macmillan, 2013), 2.

19 EWN (Eyewitness News), "SA Teen Pregnancy Rate Raises Alarm," n.p. Cited 21 July 2017. Online: http://ewn.co.za/2017/03/13/sa-teen-pregnancy-rate-raises-alarm

20 CDC, "Unmarried Childbearing," n.p. Cited 21 July 2017. Online: https://www.cdc.gov/nchs/fastats/ unmarried-childbearing.htm

21 For more information on marriage as a risk factor, see Jennifer S. Hirsch et al., The Secret: Love, Marriage, and HIV (Nashville, TN: Vanderbilt University Press, 2009).

22 AVERT, "HIV and AIDS in South Africa," n.p.

23 Lydia Boyd, Preaching Prevention: Born-again Christianity and the Moral Politics of AIDS in Uganda (Athens, OH: Ohio University Press, 2015) 2-3.

24 Ibid, 3.

25 For more information on structural violence, see Paul Farmer, Margaret Connors and Janie Simmons, ed. Women, Poverty and AIDS: Sex, Drugs, and Structural Violence (2nd ed., Monroe, ME: Common Courage Press, 2011).

26 Paul Farmer, AIDS and Accusation: Haiti and the Geography of Blame (Berkeley, CA: University of California Press, 1992), 30. Herdt, "Introduction," 18.

27 Josefina J. Card et al., The Complete HIV/AIDS Teaching Kit (New York: Springer Publishing Company, 2007), 309-310.

28 lbid, $310-311$.

29 lbid, 309-310.

30 lbid, 310-311.

31 Melissa Browning, Risky Marriage: HIV and Intimate Relationships in Tanzania (Lanham, MD: Lexington Books, 2014), 135.

32 Mark Hunter, Love in the Time of AIDS: Inequality, Gender, and Rights in South Africa (Bloomington, IN: Indiana University Press, 2010), 4.

33 lbid.

34 Ibid, 4-5.

35 Ibid, 165 
36 Ibid, 147-148.

37 Sanyu A. Mojola, Love, Money, and HIV: Becoming a Modern African Woman in the Age of AIDS (Oakland, CA: University of California Press, 2014), 43-45.

$38 \mathrm{lbid}, 6$.

$39 \mathrm{lbid}, 32-33$.

$40 \mathrm{lbid}, 36$.

$41 \mathrm{lbid}, 112-133$.

$42 \mathrm{lbid}, 89$.

$43 \mathrm{lbid}$.

44 AVERT, "Women and Girls: HIV and AIDS."

45 Hunter, Love in the Time of AIDS, 97.

46 Ibid, 198.

47 Card et al., The Complete HIV/AIDS Teaching Kit, 310-311.

$48 \mathrm{lbid}, 311$.

$49 \mathrm{lbid}, 310$.

50 UNAIDS, "When Women Lead, Change Happens," n.p. Cited 24 July 2017. Online: http://www.unaids. org/sites/default/files/media_asset/when-women-lead-change-happens_en.pdf

51 Hunter, Love in the Time of AIDS, 172. Robert Wyrod, AIDS and Masculinity in the African City: Privilege, Inequality, and Modern Manhood (Oakland, CA: University of California Press, 2016), 66-69.

52 Hunter, Love in the Time of AIDS, 171.

53 BBC, "South Africa Mini-skirt March in Protest," n.p. Cited 24 July 2017. Online: http://www.bbc.com/ news/world-africa-17078304

54 Lydia Boyd, Preaching Prevention: Born-again Christianity and the Moral Politics of AIDS in Uganda (Athens, OH: Ohio University Press, 2015), 139. Erin Moore, "What the Miniskirt Reveals: Sex Panics and Seductive Economies in Urban Uganda." Unpublished paper presented at the Program of African Studies, Northwestern University (26 April 2017), 13.

55 Ibid, 2-4.

56 Sylvia Tamale, "Crossing the Bright Red Line: The Abuse of Culture and Religion to Violate Women's Sexual and Reproductive Health Rights in Uganda," in Women and Girls Rising: Progress and Resistance around the World, ed. Ellen Chesler and Terry McGovern (New York: Routledge, 2016), 145.

57 Ibid.

58 Ibid.

59 Gayle S. Rubin, "Thinking Sex: Notes for a Radical Theory of the Politics of Sexuality," in Lesbian and Gay Studies Reader, ed. A. Habelove, M.A. Barale and D. Halperin (London: Routledge, 1993), 3-4.

60 Herdt, "Introduction," 18.

61 lbid, 18-19; Rubin, "Thinking Sex," 25.

62 Rollingstone, "The War on Planned Parenthood," n.p. Cited 24July 2017. Online: http://www.rolling stone.com/politics/news/the-war-on-planned-parenthood-20160406

63 NPR, "In Religious Freedom Debate, 2 American Values Clash," n.p. Cited 24 July 2017. Online: http://www.npr.org/2017/02/28/517092031/in-religious-freedom-debate-2-american-values-clash

64 Amanda Gouws, "Public Outrage and Hashtags Won't Slow South Africa's Shocking Rates of Violence against Women," Quartz Africa., n.p. Cited 24 July 2017. Online: https://qz.com/992704/karabomokoenas-murder-like-anene-booysen-and-reeva-steenkamp-wont-stop-south-africas-gender-violence/

65 Hunter, Love in the Time of AIDS, 173.

66 Ibid.

67 Lydia Smith, "Corrective Rape: The Homophobic Fallout of Post-apartheid South Africa," The Telegraph, n.p. Cited 24 July 2017. Online: http://www.telegraph.co.uk/women/womens-life/1 1608361/Correctiverape-The-homophobic-fallout-of-post-apartheid-South-Africa.html

68 Card et al., The Complete HIV/AIDS Teaching Kit, 310.

69 Ken Stone, "The Hermeneutics of Abomination: On Gay Men, Canaanites and Biblical Interpretation," Biblical Theology Bulletin 27/2 (Summer 1997), 40.

70 Tamale, "Crossing the Bright Red Line," 148-152; Moore, "What the Miniskirt Reveals," 1. 
71 Ezra Chitando and Sophie Chirongoma, "Introduction," in Redemptive Masculinities: Men, HIV and Religion, ed. Ezra Chitando and Sophie Chirongoma (Geneva: World Council of Churches Publications, 2012), 1. Ufo Okeke Uzodike and Christopher Isike, "Towards a Theoretical and Cultural Analysis of Dangerous Masculinities in Contemporary Africa: Can We Reinvent African Patriarchies to Curb HIV and AIDS," in Redemptive Masculinities: Men, HIV and Religion, ed. Ezra Chitando and Sophie Chirongoma (Geneva: World Council of Churches Publications, 2012) 48.

72 Fahs et al., "Introduction - Villains and Victims," 2.

73 Cheryl B. Anderson, Ancient Laws and Contemporary Controversies: The Need for Inclusive Biblical Interpretation (New York: Oxford University Press, 2009), 1.

74 See the chapter, "Age, Race, Class, and Sex: Women Redefining Difference," in Audre Lorde, Sister Outsider: Essays and Speeches (Berkeley, CA: Crossing Press, 1984/2007), 116.

75 Tamale, "Crossing the Bright Red Line," 145-146. 


\section{CONFLICT IN CONFLICT \\ Mobilising against Violence against Women and Girls in Local Faith Communities in Areas affected by Armed Conflict}

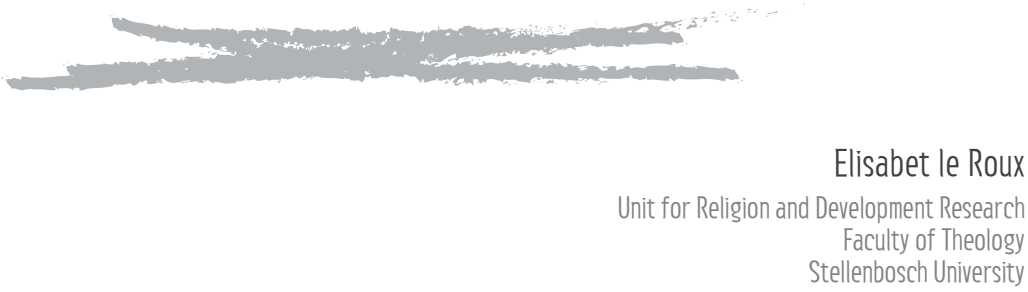

\section{Introduction}

Violence begets violence. Many studies have shown that children who experience or witness violence are more likely as adults to perpetrate violence (in the case of men) or experience violence (in the case of women). ${ }^{1}$ While still under-researched, evidence suggests that intimate partner violence (IPV) increases during times of conflict and is more common in couples who experienced or were affected by armed conflict. ${ }^{2}$ In post-conflict settings, there are often high levels of sexual violence against women. ${ }^{3}$ Communities affected by armed conflict are, therefore, some of the most challenging settings in which one can work to counter violence against women and girls (VAWG). Aside from the resource, infrastructure and security challenges, one usually has to contend with a culture of violence, especially if the community has suffered under a prolonged armed conflict. However, this makes it all the more important to do such work - where VAWG has become so normalised and accepted and is being committed with impunity, there is a desperate need for change.

One would expect the state to address this issue, especially since it has the power to make and enforce severe legal repercussions for perpetrators. However, in areas in Africa which are affected by armed conflict, ineffective or failed states have forced civil society to perform functions that are traditionally associated with the state. A particular sector of civil society, namely churches, often step into the breach. For example, the involvement and effectiveness of churches in development, service delivery, peacebuilding and promoting a democratic regime have been well documented. ${ }^{4}$

This essay explores the realities and challenges of working with faith leaders from local faith communities to counter VAWG in areas affected by armed conflict. By drawing on 
a three-year study that is currently being conducted in the eastern Democratic Republic of Congo (DRC), the "practicalities" are explored of cultivating change agents to act as catalysers for ending VAWG. While this essay focuses on what is required when working with faith leaders in resource-poor, isolated, conflict-affected settings, it is also relevant for wider reflection on the nature of engaging with faith leaders around controversial and sensitive issues such as gender equality and non-violence.

\section{Background}

The DRC has been involved in two different wars from the periods 1996 to 1997 and 1998 to $2003 .^{5}$ Although conflict continues, the current fighting is often described as postconflict violence ${ }^{6}$ with ongoing violence and regular violent outbreaks in eastern DRC. The ability to stem this conflict is complicated by the involvement of many different factions. Rwanda, Burundi, Uganda, Angola, Zimbabwe and Namibia have all (at different times) been active participants in the conflict as have various rebel groups and militias such as the infamous Maï-Maï and the Interahamwe. ${ }^{7}$ The estimation is that over five million people have thus far died in these violent conflicts and wars, millions of people have been displaced and according to the DRC government, more than a million women and girls have been sexually violated. ${ }^{8}$ These are conservative estimates. Different ceasefire agreements have been signed since 1999, but have been violated. Conflict continues in the DRC so much so that the Cadre Permanent de Concertation de la Femme Congolaise (CAFCO) states that the DRC has not experienced true peace since it gained independence. ${ }^{9}$

In 2015, Tearfund, a UK-based international FBO, and HEAL Africa, a local Congolese FBO, were awarded one of the Innovation grants under the What Works to Prevent Violence against Women and Girls Programme funded by the United Kingdom's Department for International Development (DFID). ${ }^{10}$ This grant was for implementing a new project, "Engaging with Faith Groups to Prevent Violence against Women and Girls in Conflictaffected Communities" ${ }^{11}$ The three-year intervention and research project within 15 target communities near Rethy in the Ituri Province of the DRC started in April 2015 and is scheduled to end in 2018. The ultimate aim of the project is to contribute towards the prevention of VAWG, particularly sexual violence, through changing individual attitudes and behaviours and social norms relating to gender inequality and VAWG.

It should be noted that Rethy is in the north-eastern part of the DRC, which is still racked by on-going violence from different rebel groups. The violence has been going on for decades and the eastern DRC is known for its high rates of very violent and torturous sexual assault. ${ }^{12}$ The 15 communities targeted by the intervention are in a very rural, extremely remote area, which has very little infrastructure and has had very little intervention from the local, provincial or national government, from UN agencies or from international or local NGOs. ${ }^{13}$ 
The key activity of the intervention is the selection, training and mentoring of faith leaders and gender champions within each of the communities. Faith leaders are from any faith or denomination, while gender champions are community leaders such as midwives or teachers who showed a willingness to address gender-related matters. The theory of change embraced by the project is based on the assumption that these leaders as key community influencers will spread the message to the rest of the community.

Seventy-five faith leaders (five per community) form part of the intervention. At the time of writing, the selected faith leaders have received a three-day training in August 2015 entitled “Transforming Masculinities". Refresher trainings took place in March 2016 (one day) and September 2016 (one day). Furthermore, they receive monthly mentoring and monitoring visits from the Project Officer. ${ }^{14}$

A number of research activities has been implemented to date, including a baseline household survey (with a total of 769 interviews), a longitudinal panel study, interviews and focus groups with VAWG survivors and interviews with community members. In this essay, the author primarily draws on the longitudinal individual tracking that is being done with 16 faith leaders that form part of the intervention. The panel of faith leaders that are tracked originally consisted of 20 individuals, but due to attrition 16 remain. Nine are female and seven are male. They are from seven different villages, eight are from charismatic/ Pentecostal churches and five are from mainline churches, while three are Muslim. At the time of writing, three panel visits have been done at approximately seven-month intervals.

\section{The Prevalence and Pervasiveness of Interpersonal Violence in Conflict-affected Communities}

Due to the prolonged violent history of the DRC and the current rebel action in the region, there was the expectation that the VAWG that would be disclosed and the fears that people express about violence would primarily be conflict-related and perpetrated by the different militia groups that roam the area.

Instead, it was found that IPV remains in the eyes of the community members and faith leaders the most common form of violence in the region. The challenges and issues related to IPV are discussed most often when participants talk about violence. The baseline household survey data showed that $68,8 \%(n=167)$ of the women who are in relationships reported having experienced some form of IPV within the preceding 12 months, while 68,2\% $(\mathrm{n}=163)$ of men reported perpetrating IPV in the preceding 12 months. ${ }^{15}$ Furthermore, while the rate of non-partner sexual violence within the preceding 12 months was high (with 20,8\% of respondents reporting experiencing it one or more times), only in $6 \%$ of the cases was the perpetrator a militia member or other unknown persons. ${ }^{16}$ Thus, non-partner 
sexual violence is being perpetrated by family members or other known members of the community.

In the panel study with faith leaders, while stranger rape was listed when asked to name common forms of VAWG, violence against women and girls was consistently discussed within the context of marital relationships or the community, and rarely with reference to rebel groups or soldiers. Faith leaders identified various forms of IPV perpetrated by a man against a woman as the key concern within their communities when it comes to violence. In particular, crops and property are seen as key instigators of IPV.

In trying to understand why IPV increases during and after armed conflict, Horn et al. argue that those who experience their status within the family to be inconsistent with social norms may use violence as a way of compensating for their loss of power. ${ }^{17}$ Women are often better able to maintain their gender identity despite conflict as they keep their traditional roles and responsibilities. But men are more likely to suffer a loss of gender identity, especially if that identity is built around ideas of being a protector and provider. ${ }^{18}$ This corresponds with James Messerschmidt's explanation of male violence. ${ }^{19}$ He argues that criminal behaviour by men is because other ways of enacting masculinity are not available to them. Violence against women is such a form of criminal behaviour that serves to affirm masculinity and violence, and is resorted to also in the private sphere. Wife battering and rape are common ways of asserting masculinity in the face of unemployment or low occupational status. ${ }^{20}$ As the willingness and ability to use violence are related to some forms of masculinity, violence is often resorted to when more acceptable, traditional displays of masculinity (such as steady employment and a good salary) are unavailable. ${ }^{21}$

However, IPV can also be facilitated by a culture of violence and violent sexuality. Within military masculinity, violence and the willingness and ability to use it are of extreme importance. ${ }^{22}$ Furthermore, the military devalues women and typically feminine traits, while at the same time it values men and typically manly traits, which promote the needed violent agenda. ${ }^{23}$ The emphasis on gender differentiation, as well as on violence, leads to violence against women, and especially sexual violence, which then becomes a normalised form of aggression. ${ }^{24}$ Unfortunately, this military culture also affects civilian masculinities. In post-conflict settings, military masculinities often give rise to what has been termed a form of hypermasculinity among both civilian and military men. Hypermasculinity leads to civilian men displaying the same militarised, hypermasculine attitudes of violent aggression (verbal or physical), sexual relations that establish male dominance and female submissiveness with no concern for the female's experience and entering into dangerous situations. ${ }^{25}$ Militarisation thus shapes not only the masculinity of soldiers, but also that of civilian men in areas affected by armed conflict. ${ }^{26}$ 
However, it does not mean that these violent practices only entered these communities with the outbreak of armed conflict. Male privilege, wife beating, forced marital sex - these are socially accepted, long-standing practices. Prior to the wars, violence against women was not an uncommon occurrence. On the contrary, customary law endorsed it. In the DRC's dual legal system, customary law still allows transactional fines for sexual abuses. Thus, for example, the rape of a girl is resolved by the victim's family and the perpetrator's family agreeing on the form of restitution that should be paid to the girl's family. ${ }^{27}$ Customary law remains powerful, especially in rural and conflict-ridden areas. ${ }^{28}$

In the panel visits with the selected faith leaders, one can also see the pervasiveness of beliefs regarding women's lesser value compared to men and how this justifies VAWG. In the first panel visit, conducted prior to the start of the intervention, the majority of the faith leaders felt that their faith places men above women and that wives should submit to their husbands. In a focus group discussion during the first panel visit, violence against women was explained in the following way:

Because (violence against women) can be due to lack of respect of rights, everyone should know what his or her responsibilities is, as Ephesians 5:24 and so on says that: the wife has duties she has to do to her husband by submitting herself to him and all that she is instructed. And the husband also should not miss [sic] to respect the wife's rights, otherwise everything won't work well in their home. So everyone should know what his or her duties within the family are. This is what is destroying people's homes: because women are not submitting themselves to their husbands. And this pushes the husbands to not respect their wives' rights if the wives are not submissive. All this is bringing conflicts in homes.

(FGD, PV1)

At the time of writing - eight months into the intervention - ideas about gender equality are for some of these targeted faith leaders still reconcilable with beliefs about submission. In other words, even though men and women are equal, women must submit to men. When seeking counselling from these faith leaders, abused wives are still fairly consistently advised to stay in abusive relationships. Even by the third panel visit, some of the faith leaders struggle to reconcile their newfound understanding of gender equality and non-violence with their long-standing beliefs in male superiority and female submission, particularly as they play out in terms of wife beating and male rights to sex. This is discussed in more detail below.

\section{The Counter-intuitive Nature of Male versus Female Faith Leader Involvement}

Increasingly, GBV interventions target men and boys specifically, sometimes even exclusively, based on the argument that such interventions are needed in order to dismantle how patriarchy and rape culture operate politically, socially and psychologically. ${ }^{29}$ Some scholars are strongly critical of this approach and argue that few if any male-focused 
projects are truly pro-feminist and transformative. How, it is asked, can men dismantle a system that benefits and privileges them ${ }^{30}$

Elsewhere, I have pointed out the importance of engaging with both women and men when responding to GBV within local faith communities. ${ }^{31}$ It was argued that in faith communities, in the Global South in particular, an integrated approach is needed as patriarchal structures are so dominant and restrictive that no headway could be made without including men and male faith leaders as partners. What Rethy shows us, is that such an integrated approach is important, not only in order to have access to a community, but also because male faith leaders are counter-intuitively, potentially more active change agents than female faith leaders.

In Rethy, it is the male faith leaders on the panel who are the best at understanding and internalising difficult concepts such as "gender equality", who apply the concepts in their reading of their sacred texts, who consistently denounce all forms of VAWG and who enthusiastically support and promote gender equality in their sermons and community awareness campaigns. During the last panel visit in November 2016, all seven of the male panel members were eloquent in defining and motivating gender equality and in describing their work on gender equality in the community. The following quote from the third panel visit's interview with an Imam illustrates this point:

... In fact, in all my teachings, I speak about gender equality the most ... This is because I know it is something that is needed in our community. When we talk about gender equality, I often say, God created men and women equal. If God wanted, he would have said that men should rule over their wives and wives should not rule over their husbands. But he never said that; and that is what I keep emphasising when I go out for awareness campaigns ... So, gender equality was not happening here in the past. We used to witness men treating women as though they were their slaves.

(FLm16, PV3)

Counterintuitively, it is the female faith leaders who support views that disempower women. During the last panel visit, three female faith leaders still quoted Scripture to justify male domination and female submission. Directly or indirectly, all of the female faith leaders to some extent tried to justify wife beating and forced marital sex and some still opposed gender inequality. One female faith leader said:

Most often, I have the habit of counselling people to not have the idea of gender equality since it is because of that there is violence. Why? I have just said that, for example, a man can say that doing laundry or even cooking it's not my job; whereas if the woman is also busy, a man can cook or even do the laundry; and if one does not do that, the man would say that this is your job and through that there is violence straightaway. And it is not good to put that into practice. That is what I teach in the community - to not have the idea of gender equality

(FLfO4, PV3)

Rethy has shown us that there may be a need to work in a more concerted and focused way with some female faith leaders in order to change their thinking. But why are some female faith leaders complicit in beliefs and practices that subjugate and disempower 
women? One possible reason is an ideology that Sarojini Nadar identifies as "formenism". She explains that "[f]ormenism, like masculinism, subscribes to a belief in the inherent superiority of men over women ... but unlike masculinism, it is not an ideology developed and sustained by men, but constructed, endorsed, and sustained by women." ${ }^{32}$ This ideology created and upheld by women chiefly benefits men. Women subscribe to it for a number of possible reasons - it gives men power that is disciplinary and not forceful; it increases men's responsibility, which can ultimately reduce the household responsibilities that women traditionally carry, and it helps to reduce existential anxiety. ${ }^{33}$ In a process of patriarchal bargaining, "formenism" thus buys into a "liberation through submission" discourse as doing so is judged to improve the lot of women. However, while it may do so in the short term, it fundamentally disallows women's agency and equality, positioning women as the weaker "other" and ultimately putting women's well-being and freedom at risk. ${ }^{34}$

Another possible reason might be that women who have sought and found power within a patriarchal system consciously or unconsciously are loath to give up the system, not knowing whether they will again find power. Some female responses to female genital mutilation and cutting (FGM/C) arguably illustrate this whereby some women who have experienced FGM/C vehemently defend and promote the practice. In many countries, $\mathrm{FGM} / \mathrm{C}$ is synonymous with women's power and as a process of women's initiation it is highly organised and hierarchical. ${ }^{35}$

While these are possible reasons why women uphold patriarchy, they do not explain why male faith leaders subvert it. It is the male faith leaders on the panel who have internalised a progressive approach - one that affirms gender equality and condemns all forms of violence - much more than the female faith leaders. A possible reason might be that embracing gender equality requires more of a change of mind and heart and commitment from a man than it does from a woman. Responses suggest that men have had to grapple with a mind shift regarding their own behaviours, which in turn has led to embodied self-change in a way that women in the group have not always been required to do. One male faith leader explains how his own life has changed thus:

We have found that this awareness has changed us within our own households as couples and from there we went to the community... From what I am seeing, as I said, it started transforming my household because we are a couple. The wife also participates in the awareness at church. I have realised that I have also changed. When she changed, I changed and so did the children. We are all fine.

(FLm13, PV3)

\section{The Training of Trainers Model}

In the intervention in the 15 target communities in Rethy, a training of trainers (ToT) model is used across a number of disciplines. ToT is an educational model which relies on a cascade approach, whereby training is conducted at two or more levels by trainers selected from 
the level above. ${ }^{36}$ The ToT model within community-based work relies on an organising institution with expertise (and usually funding) relating to the subject matter that identifies potential trainers with ties to the community that has been selected for training. These potential trainers are then trained by the organising institution, which provides the education, instructional tools and programmatic guidelines. The trained trainers in turn are then expected to provide specific training to the target community to which they are linked. ${ }^{37}$

The ToT model is often used by FBOs in responding to GBV for it has a number of advantages. First and foremost, while it originally relies on the organising institution's resources, it can theoretically be sustained indefinitely by the trainers based in the community. Thus, it is a cost-efficient model of intervention. Sustainability is also supported by the fact that there are a number of trainers in each community. Thirdly, as the model relies on the trained trainers' embeddedness within the community, it benefits from their established trust and credibility. While the organising institution provides scientific credibility to the training programme, the information is trusted when delivered by a trusted insider. Furthermore, training programmes with roots in a community are viewed as empowering to the community. Lastly, the ToT model benefits from and promotes social capital within the community as it facilitates the building of relationships in the community. This in turn maximises the benefit of the programme at least theoretically. ${ }^{38}$

In Rethy, it appears that the ToT model is working, although the endline household survey will be needed for conclusive proof regarding its community-wide impact. However, the longitudinal tracking shows us that the 16 faith leaders on the panel are already "paying it forward". This is demonstrated in two areas, namely their activities on violence and their activities on gender equality.

In terms of activities on VAWG, there was a remarkable increase after the panel received the original (2015) training by HEAL Africa and Tearfund. Of the 16 panel members, only five (four men and one woman) had done any teaching or talk to address or prevent VAWG in the six months preceding the first panel visit. However, after being trained for the first time, all of the panel members organised sessions on VAWG within their respective communities. These sessions were formal such as sermons or sessions during or just after a church service, as well as more ad hoc, for example, talking to a group of women about VAWG while cultivating fields. It has continued this way for more than a year.

In terms of their activities around gender equality, there was once again a definite increase after the faith leaders were trained by HEAL Africa and Tearfund. In the six months preceding the first panel visit, only three of the faith leaders had done any kind of teaching on gender equality. In the period between the first and second panel visits, at least eight 
faith leaders conducted sessions on gender equality (ambiguity in the data means that there might have been more). By the third panel visit, all of the panel members except one had organised sessions on gender equality in the preceding eight months. A good example of a very active member in this regard is FLm16 an Imam who is passionate about teaching on gender equality. He uses both the Quran and the Bible during his sessions and stated that:

[A session that went well] is definitely the one that I did last Friday at the mosque. We had an awareness campaign there, and we used a Quran verse that is closely related to the one in Genesis that says God created us all equal. We spoke about that last Friday. And on Sunday, our theme was gender equality. We talked about it and we even made reference to a verse in the book of John where it says something about sexual violence, which brings havoc in many families and even in the churches. We spoke about it and people listened. Even this coming Friday we will talk about it again. We often use scriptures to explain so that people can understand well what we mean.

(FLm16, PV3)

Further evidence of the impact of the faith leaders' increased activities is community members' reflections on it. Interviews with community members show that they have begun to appreciate and internalise what is being shared by the faith leaders. They all felt that the sessions conducted by the faith leaders and gender champions are changing how people see men and women, as well as the relationships between men and women. For example, three male community members' explanations of how the faith leaders' activities had changed their relationships and their own perpetration of violence are noted below:

I felt very good because I am not without knowledge of this. I, myself was also in one of these cases of violence; I was also in part in [sic] that violence. So, exactly as they were giving explanations about it; I realised that I had fallen into that too because at home for example or within the community for example, or anywhere, one cannot always be unfair; there are times when we must also let go. I felt that I found it beneficial that such people go to villages as it can put someone on the right path, just like that.

I was abusive on economic violence aspect; even physical violence. After that teaching I live in peace with my wife at home.

(CMm14)

When I heard the teaching, first of all, I felt that it is a good teaching as for my family it helps to make sure we help each other ... What touched me is that when you are a father in a family you must not let anger control you; and don't have a habit of beating people physically. Also, you should not react in a way that can harm somebody physically. Well, I saw that it can be a good thing helping people to live in peace in marriage.

(CMm10)

Why is the ToT model working in Rethy? Over the past ten years I have studied and evaluated various faith-based models of GBV-intervention, most of which relied on some form of the ToT model. And so very often it fails, for one of two reasons. Firstly, faith leaders are unmotivated to do trainings within the communities citing their busy schedules or lack of payment as reasons. Or there is a 'broken telephone' effect with the complex 
gender messaging that is communicated at the original training gradually becoming more and more distorted as it is passed on to the community.

These two issues are also what much of the literature identifies as problematic with the ToT model. The "broken telephone" effect is a common complaint; the information that is transferred may be diluted, or even skewed when delivered by intermediate trainers. ${ }^{39}$ Some scholars have argued that this happens where trainings are conducted in a purely transmissive mode and that active participation and mode of training - which are experiential and reflective - are needed at all levels in order for the cascade approach to work. ${ }^{40}$ Thus, it appears that it is the linear nature of the model with its implicit assumptions of a unidirectional flow of information, which often challenges the effectiveness of the model. ${ }^{41}$ Furthermore, fidelity of implementation is a challenge as trainers do not always strictly adhere to the curriculum and training protocol. ${ }^{42}$ At the same time, expecting those trained to adhere rigidly to the curriculum and protocol can potentially jeopardise their willingness to undergo, and their effectiveness in, training. ${ }^{43}$

As seen in the previous section, there is a "broken telephone" effect in Rethy. This is possibly because the training that the faith leaders received is not intensive enough. While these faith leaders have shown remarkable change and activity within their communities, there remain concerning beliefs on the relative value of men and women (as discussed earlier). Tearfund and HEAL Africa have recognised these and are in the process of organising added training sessions. However, it is clear that in the case of issues as embedded and sensitive as gender equality and gendered violence, training should continue over an extended period. In Rethy, the faith leaders have been meeting with a mentor at least once a month and this has provided support and to some extent educational follow-up for them. More in-depth training and guidance are needed as some of these faith leaders themselves struggle with issues that they are expected to teach on in their communities.

Sadly, trainers refusing to train is a universal complaint. In a study by Hahn et al., less than half of the trainers who were trained went on to conduct trainings. ${ }^{44}$ This appears to be - across the different fields in which the ToT model is used - one of the biggest challenges, leading to the strong recommendation from many programmes that trainers should be supported through educational follow-up, assistance in marketing and logistics and compensation or some form of incentivising. ${ }^{45}$ Surprisingly, very few trained faith leaders on the panel are unwilling to train their community members. Why is this so? The research will explore this further in the coming months, but for now it offers the following tentative suggestions.

Firstly, the intervention is being implemented in an isolated, rural, resource-poor setting affected by conflict. The message that is offered is thus fresh and novel. Could that be the reason that the faith leaders are willing and eager to spread it and the community members 
are particularly receptive? When comparing what is happening in Rethy to where a ToT model has been implemented in settings where multiple organisations are doing training and education around GBV, it appears that the ToT model is most effective when it is implemented in a setting where there is low-saturation of the message being conveyed.

It could also be that faith leaders in such communities are positioned and see themselves and their roles differently compared to faith leaders in more urban settings. The trained faith leaders in Rethy are not being paid to conduct these sessions and only receive a stipend to cover their travel costs. Moreover, they are not less busy than faith leaders in urban areas. On the contrary, almost all of them have other jobs and land to farm as well. Could it be that the cohesiveness of the community makes a difference since these are smaller, isolated communities where people know each better? Does a sense of community cohesion increase faith leaders' willingness to conduct such awareness raising as they themselves are aware of the value of the message and want to improve the community? These are some of the issues that will be explored further in future.

\section{Change - Being Realistic}

Sustainable Development Goal 5 calls for the world to "achieve gender equality and empower all women and girls" ${ }^{46}$ While this is, of course, what interventions around gender inequality and gender-based violence should strive to achieve, making this goal the standard around which the effectiveness of all interventions are judged is arguably unfair and irresponsible. One has to take the context in which an intervention is based into account and be realistic in terms of the change that can and should be expected, especially given the timeframe of an intervention. The issue of wife-beating in Rethy illustrates this.

The training and mentoring that faith leaders have received has been progressive and consistent in terms of content - decidedly opposed to all forms of violence against women, convincingly explaining and arguing for gender equality and engaging with Scripture to oppose VAWG and argue for gender equality. Yet, 18 months into the intervention, some of the faith leaders were still making statements that support violence and gender inequality when they explained how they counsel couples on wife-beating. For example:

I gave them advice. I told them that: 'You are not supposed to make use of violence. Your wife is not a drum that you can beat. As for you, the wife, you should behave and be obedient to your husband. That's not a sin. If you had listened to what he had told you, none of this would have happened.'

(FLf18, PV3)

(In advising a couple where the man was beating his wife because she complained about his infidelity) That man said, he loves both of them, I told him it is good to love two women. Just remain with one wife only, it is enough. You can create conflict like that between the two.

(FLf23, PV3) 
It is demoralising! Has the intervention achieved nothing - why are they still saying that women must behave and be obedient, why are they still blaming women, why is it still acceptable for men to be unfaithful? However, this knee-jerk reaction only shows the importance of having realistic expectations in order not to be blinded to positive changes. Yes, these quotes can be interpreted as showing that patriarchy and victim-blaming are alive and well, because they are. However, they can also be read as signalling tremendous change. In the first quote, the female faith leader used to strongly support wife-beating, but now she is strongly opposed to it. The female faith leader in the second quote also used to support wife-beating, but now she opposes it. It is true that she still sees it as acceptable for a husband to be adulterous, but now she counsels the man not to beat his wife. We need to keep in mind the "starting point" and not just the ultimate end-goal.

SGD \#5 is an excellent goal and it is what one should strive towards. However, it is also important to be sensitive to context. Evaluating impact has to take into account local realities: be cognisant of the lenses worn while working with change agents, as well as of the expectations that result from it. Otherwise, there is the risk of being blind to the positive changes that have actually begun.

\section{Conclusion}

It is extremely challenging to counter VAWG in settings affected by armed conflict. The resources needed to do so holistically are always limited and often non-existent. This is why engaging with local faith communities is potentially an effective way of producing change. Many African societies affected by armed conflicts are poor, agrarian societies where local faith communities such as churches and mosques fulfil an important role in giving support, guidance and social structure to the community. Local faith communities are thus positioned to influence and take the lead in issues and problems with which they are not traditionally associated.

Tearfund and HEAL Africa's intervention in Rethy, DRC is showing that local faith communities, particularly the faith leaders of these communities, can be effective agents of introducing new ideas about gender equality and non-violence to the broader community. Despite the infrastructural challenges and the limited resources, despite how common and accepted VAWG and specifically IPV are and despite how culturally and religiously engrained ideas about male power and female submissiveness are, these faith leaders have begun to influence their communities. By studying how and why they do so in an area affected by armed conflict, one learns valuable lessons about engaging with faith leaders as change agents around gender equality and non-violence in general. The findings suggest that male faith leaders might at times be more receptive change agents than their female counterparts and that this needs to be taken into account in programme planning. 
Furthermore, the effectiveness of a ToT intervention could be due to the previous low saturation of gender messaging and the existence of social cohesion within a community. Therefore, the nature of change should be evaluated based on the starting point and not on the ultimate goal of an intervention.

The last year of the qualitative research, and especially the endline household survey, are key to a deeper understanding of how and why this intervention is making an impact on these 15 communities in Rethy. Indeed, much has already been learned about how faith leaders can be change agents in their communities.

\section{Bibliography}

Abrahams, Naeemah and Jewkes, Rachel. "Effects of South African Men's Having Witnessed Abuse of Their Mothers during Childhood on Their Levels of Violence in Adulthood." American Journal of Public Health 95 (2005): 1811 -1816. https://doi.org/10.2105/AJPH.2003.035006

Akina Mama wa Afrika. "Country Research: Democratic Republic of Congo (DRC)." 15-42. Cited 10 January 2014. Online: http://www.google.co.za/url? sa $=t \& r c t=j \& q=\& e s r c=s \& f r m=1 \&$ source $=$ web\&cd $=1 \& v e d=0 C C g$ QFiAA\&url=http\%3A\%2F\%2Fwww.akinamamawaafrika.org\%2Findex.php\%2Fpublications\%2Fannualreport\%2Fdoc_download\%2F40-country-research-democratic-republic-of-congodrc\&ei=6MPPUtnyCoP1。 ATglYGgAg\&usg=AFQjCNEllqthXCQ6M7p7fkt2vlY8_jfRmw\&bvm=bv.59026428,d.cGU

Akoko, Robert M. and Oben, Timothy M. "Christian Churches and the Democratization Conundrum in Cameroon." Africa Today 52 (2006): 25-48. https://doi.org/10.2979/AFT.2006.52.3.24

CAFCO. "Security Council Resolution 1325: Civil Society Monitoring Report, Democratic Republic of Congo." No Pages. Cited 15 July 2014. Online: http://www.gnwp.org/wpcontent/uploads/2010/02/DRC.pdf

Casey, Sara E.; Gallagher, Meghan C.; Makanda, Babou R.; Meyers, Janet L.; Vinas, Mereia C. and Austin, Judy. "Care-seeking Behavior by Survivors of Sexual Assault in the Democratic Republic of the Congo." American Journal of Public Health 101 (2011): 1054-1055. https://doi.org/10.2105/ AJPH.2010.300045

Garcia-Moreno, Claudia; Jansen, Henrica A.F.M.; Ellsberg, Mary; Heise, Lori and Watts, Charlotte H. "Prevalence of Intimate Partner Violence: Findings from the WHO Multicountry Study on Women's Health and Domestic Violence." The Lancet 368 (2006): 1260-1269. https://doi.org/10. 1016/S0140-6736(06)69523-8

Gifford, Paul. "Trajectories in African Christianity." International Journal for the Study of the Christian Church 8 (2008): 275-289. https://doi.org/10.1080/14742250802347935

Goldstein, Joshua S. War and Gender: How Gender Shapes the War System and Vice Versa. Cambridge: Cambridge University Press, 2001.

Hahn, Ellen J.; Powers Noland, Melody; Rayens, Mary K. and Myers Christie, Dawn. "Efficacy of Training and Fidelity of Implementation of the Life Skills Training Program." Journal of School Health 72 (2002): 282-287. https://doi.org/10.1111/j.1746-1561.2002.tb01333.x

Hayes, David. "Cascade Training and Teachers' Professional Development." ELT Journal 54 (2000): 135-145. https://doi.org/10.1093/elt/54.2.135

Horn, Rebecca; Puffer, Eve S.; Roesch, Elisabeth and Lehmann, Heidi. "Women's Perceptions of Effects of War on Intimate Partner Violence and Gender Roles in Two Post-conflict West African Countries: Consequences and Unexpected Opportunities." Conflict and Health 8 (2014): 1-13. https://doi.org/10.1 186/17521505-8-12

Jones, Nicola; Cooper, Janice; Presler-Marshall, Elizabeth and Walker, David. "The Fallout of Rape as a Weapon of War: The Life-long and Intergenerational Impacts of Sexual Violence in Conflict." No Pages. Cited 5 July 2014. Online: http://www.odi.org/sites/odi.org.uk/files/odi-assets/publicationsopinionfiles/8990.pdf

Koenig, Michael A.; Stephenson, Rob; Ahmed, Saifuddin; Jejeebhoy, Shireen J. and Campbell, Jacquelyn. "Individual and Contextual Determinants of Domestic Violence in North India." American Journal of Public Health 96 (2006): 132-138. https://doi.org/10.2105/AJPH.2004.050872 
Krienert, Jessie L. "Masculinity and Crime: A Quantitative Exploration of Messerschmidt's Hypothesis." No Pages. Cited 15 July 2014. Online: http://www.sociology.org/content/vol7.2/01_krienert.html

Le Roux, Elisabet and Bowers-Du Toit, Nadine. "Men and Women in Partnership: Mobilizing Faith Communities to Address Gender-based Violence." Diaconia 8 (2017): 23-37. https://doi.org/10.13109/ diac.2017.8.1.23

Lwambo, Desiree. "'Before the War, I Was a Man': Men and Masculinities in the Eastern Democratic Republic of Congo." Gender \& Development 21 (2013): 47-66. https://doi.org/10.1080/13552074.2013.769771

Mbambi, Annie M. and Faray-Kele, Marie-Claire. "Gender Inequality and Social Institutions in the D.R. Congo." No Pages. Cited 10 January 2014. Online: http://www.peacewomen.org/assets/file/Resources/NGO/ hrinst_genderinequalityinthedrc_wilpf_december2010english.pdf

McLean, Lyndsay. "TA Visit to Tearfund DRC Project: 20th-28th February 2017." Unpublished Report. Tearfund, 2017.

Meer, Shamim. "Feminist Contributions, Challenges and Claims." Agenda 27 (2013): 90-99. https://doi.org/ 10.1080/10130950.2013.798958

Meger, Sara. "Rape of the Congo: Understanding Sexual Violence in the Conflict in the Democratic Republic of Congo." Journal of Contemporary African Studies 28 (2010): 1 19-135. https://doi.org/10.1080/02 589001003736728

Messerschmidt, James W. Masculinities and Crime: Critique and Reconceptualization of Theory. Lanham, MD: Rowman \& Littlefield Publishers, 1993.

Mosher, Donald L. and Sirkin, Mark. "Measuring a Macho Personality Constellation." Journal of Research in Personality 18 (1984): 150-163. https://doi.org/10.1016/0092-6566(84)90026-6

Nadar, Sarojini and Potgieter, Cheryl. "Living It out. Liberated through Submission? The Worthy Woman's Conference as a Case Study of Formenism." Journal of Feminist Studies in Religion 26 (2010):141-151. https://doi.org/10.2979/fsr.2010.26.2.141

Neef, Nancy A. "Research on Training Trainers in Program Implementation: An Introduction and Future Directions." Journal of Applied Behavior Analysis 28 (1995): 297-299. https://doi.org/10.1901/jaba. 1995.28-297

Orfaly, Rebecca A.; Frances, Joshua C.; Campbell, Paul; Whittemore, Becky; Joly, Brenda and Koh, Howard. "Train-the-trainer as an Educational Model in Public Health Preparedness." Journal of Public Health Management Practice (2005): S123-S127. https://doi.org/10.1097/00124784-20051 1001-00021

Péclard, Didier. "Religion and Politics in Angola: The Church, the Colonial State and the Emergence of Angolan Nationalism, 1940-1961." Journal of Religion in Africa 28 (1998): 160-186. https://doi.org/ $10.2307 / 1581711$

Peterman, Amber; Palermo, Tia and Bredenkamp, Caryn. "Estimates and Determinants of Sexual Violence against Women in the Democratic Republic of Congo." American Journal of Public Health 101 (2011): 1060-1067. https://doi.org/10.2105/AJPH.2010.300070

Pfeiffer, James. "Civil Society, NGOs, and the Holy Spirit in Mozambique." Human Organization 63 (2004): 359-372. https://doi.org/10.17730/humo.63.3.wrOrc09qeyafn84l

Ross, Kenneth R. "'Worrisome Trends': The Voice of the Churches in Malawi's Third Term Debate." African Affairs 103 (2004): 91-107. https://doi.org/10.1093/afraf/adh001

Sabar-Friedman, Galia. "Church and State in Kenya, 1986-1992: The Churches' Involvement in the 'Game of Change'." African Affairs 96 (1997): 25-52. https://doi.org/10.1093/oxfordjournals.afraf.a007819

Sandilands, Maggie; Jewkes, Rachel and Scott, Nigel. "Engaging with Faith Groups to Prevent Violence against Women and Girls in Conflict-affected Communities: Baseline Findings from the Democratic Republic of Congo." Tearfund, UK, 2017.

Taylor, Jenny. "Taking Spirituality Seriously: Northern Uganda and Britain's 'Break the Silence' Campaign." The Round Table 94 (2005): 559-574. https://doi.org/10.1080/00358530500303668

United Nations. "Goal 5: Achieve Gender Equality and Empower All Women and Girls." No Pages. Cited 13 June 2017. Online: http://www.un.org/sustainabledevelopment/gender-equality/

US Department of State. "Background Note: Democratic Republic of the Congo." No Pages. Cited 31 October 2012. Online: http://www.state.gov/r/pa/ei/bgn/2823.htm

Walsh, Shannon. "Addressing Sexual Violence and Rape Culture: Issues and Interventions Targeting Boys and Men." Agenda 29 (2015): 134-141. https://doi.org/10.1080/10130950.2015.1050817

Willett, Susan. "Introduction: Security Council Resolution 1325: Assessing the Impact on Women, Peace and Security." International Peacekeeping 17 (2010):142-158. https://doi.org/10.1080/13533311 003625043 


\section{Endnotes}

1 Naeemah Abrahams and Rachel Jewkes, "Effects of South African Men's Having Witnessed Abuse of Their Mothers during Childhood on Their Levels of Violence in Adulthood," American Journal of Public Health 95 (2005): 181 1-1816. Michael A. Koenig et al., "Individual and Contextual Determinants of Domestic Violence in North India," American Journal of Public Health 96 (2006): 132-138. Claudia Garcia-Moreno et al., "Prevalence of Intimate Partner Violence: Findings from the WHO Multicountry Study on Women's Health and Domestic Violence," The Lancet 368 (2006): 1260-1269.

2 Rebecca Horn et al., "Women's Perceptions of Effects of War on Intimate Partner Violence and Gender Roles in Two Post-conflict West African Countries: Consequences and Unexpected Opportunities," Conflict and Health 8 (2014): 1-13, 2.

3 Nicola Jones et al., "The Fallout of Rape as a Weapon of War: The Life-long and Intergenerational Impacts of Sexual Violence in Conflict," n.p. Cited 5 July 2014]. Online: http://www.odi.org/sites/odi. org.uk/files/odi-assets/publications-opinionfiles/8990.pdf

4 Galia Sabar-Friedman, "Church and State in Kenya, 1986-1992: The Churches' Involvement in the 'Game of Change'," African Affairs 96 (1997): 25-52. Péclard Didier, "Religion and Politics in Angola: The Church, the Colonial State and the Emergence of Angolan Nationalism, 1940-1961," Journal of Religion in Africa 28 (1998): 160-186. James Pfeiffer, "Civil Society, NGOs, and the Holy Spirit in Mozambique," Human Organization 63 (2004): 359-372. Kenneth R. Ross, "'Worrisome Trends': The Voice of the Churches in Malawi's Third Term Debate," African Affairs 103 (2004): 91-107. Jenny Taylor, "Taking Spirituality Seriously: Northern Uganda and Britain's 'Break the Silence' Campaign," The Round Table 94 (2005): 559-574. Robert M. Akoko and Timothy M. Oben, "Christian Churches and the Democratization Conundrum in Cameroon," Africa Today 52 (2006):25-48. Paul Gifford, "Trajectories in African Christianity," International Journal for the Study of the Christian Church 8 (2008): 275-289.

5 CAFCO, "Security Council Resolution 1325: Civil Society Monitoring Report, Democratic Republic of Congo," (2010), n.p. Cited 15 July 2014. Online: http://www.gnwp.org/wpcontent/uploads/2010/ 02/DRC.pdf

6 The term is used to indicate the continued existence of violence, even though peace is declared formally.

7 US Department of State, "Background Note: Democratic Republic of the Congo," (2012), n.p.

Cited 31 October 2012. Online: http://www.state.gov/r/pa/ei/bgn/2823.htm

8 CAFCO, "Security Counsel," n.p.; US Department of State, "Background Note." Amber Peterman, Tia Palermo and Caryn Bredenkamp, "Estimates and Determinants of Sexual Violence against Women in the Democratic Republic of Congo," American Journal of Public Health 101 (2011): 1060-1067, 1060.

9 CAFCO, "Security Counsel," n.p.

10 This study was funded by UK aid from the UK government; however, the views expressed do not necessarily reflect the UK government's official policies.

11 Tearfund and HEAL Africa provided data from the Engaging with Faith Groups to Prevent Violence against Women and Girls in Conflict-affected Communities project, funded by What Works.

12 Annie M. Mbambi and Marie-Claire Faray-Kele, "Gender Inequality and Social Institutions in the D.R. Congo," (2010), n.p. Cited 10 January 2014. Online: http://www.peacewomen.org/assets/file/ Resources/NGO/hrinst_genderinequalityinthedrc_wilpf_december2010english.pdf. Sara E. Casey et al., "Care-seeking Behavior by Survivors of Sexual Assault in the Democratic Republic of the Congo," American Journal of Public Health 101 (2011): 1054-1055. Sara Meger, "Rape of the Congo: Understanding Sexual Violence in the Conflict in the Democratic Republic of Congo," Journal of Contemporary African Studies 28 (2010): 119-135. Peterman et al., "Estimates and Determinants," 1060.

13 Lyndsay McLean, "TA Visit to Tearfund DRC Project: 20th-28th February 2017," Unpublished Report, Tearfund, 2017.

14 McLean, "TA Visit," n.p.

15 Maggie Sandilands, Rachel, Jewkes and Nigel Scott, "Engaging with Faith Groups to Prevent Violence against Women and Girls in Conflict-affected Communities: Baseline Findings from the Democratic Republic of Congo," Unpublished Report, Tearfund, 2017.

16 Ibid, 31

17 Horn et al., "Women's Perceptions," 10.

18 lbid, 10.

19 James W. Messerschmidt, Masculinities and Crime: Critique and Reconceptualization of Theory (Lanham, MD: Rowman \& Littlefield Publishers, 1993), 85.

20 lbid, 149. 
21 Jessie L. Krienert, "Masculinity and Crime: A Quantitative Exploration of Messerschmidt's Hypothesis," (2003), n.p. Cited 15 July 2014. Online: http://www.sociology.org/content/vol7.2/01_krienert.html

22 Meger, "Rape of the Congo," 122.

23 Ibid, 122. Susan Willett, "Introduction: Security Council Resolution 1325: Assessing the Impact on Women, Peace and Security," International Peacekeeping 17 (2010): 142-158.

24 Joshua S. Goldstein, War and Gender: How Gender Shapes the War System and Vice Versa (Cambridge: Cambridge University Press, 2001).

25 Donald L. Mosher and Mark Sirkin, "Measuring a Macho Personality Constellation," Journal of Research in Personality 18 (1984): 150-163.

26 Desiree Lwambo, "'Before the War, I Was a Man': Men and Masculinities in the Eastern Democratic Republic of Congo," Gender \& Development 21 (2013): 47-66.

27 Meger, "Rape of the Congo," 129. Akina Mama wa Afrika, "Country Research: Democratic Republic of Congo (DRC)," 15-42. Cited 10 January 2014. Online: http://www.google.co.za/url? sa=t\&rct=i\&q= \&esrc $=s \& f r m=1 \&$ source $=$ web\&cd $=1 \&$ ved $=0 C C g Q F j A A \& u r l=h+t p \% 3 A \% 2 F \% 2 F w w w . a k i n a m a m a w a$ afrika.org\%2Findex.php\%2Fpublications\%2Fannual-report\%2Fdoc_download\%2F40-country-researchdemocratic-republic-of-congodrc\&ei $=6 \mathrm{MPPU}$ tnyCoP1 oATglYGgAḡ\&usg =AFQjCNEllqthXCQ6M7p7fkt2v IY8_jfRmw\&bvm=bv.59026428,d.cGU

28 Akina Mama wa Afrika, "Country Research," 21.

29 Shannon Walsh, "Addressing Sexual Violence and Rape Culture: Issues and Interventions Targeting Boys and Men," Agenda 29 (2015): 134-141.

30 Ibid, 138-139. Shamim Meer, "Feminist Contributions, Challenges and Claims," Agenda 27 (2013): 90-99.

31 Elisabet le Roux and Nadine Bowers-Du Toit, "Men and Women in Partnership: Mobilizing Faith Communities to Address Gender-based Violence," Diaconia 8 (2017): 23-37.

32 Sarojini Nadar and Cheryl Potgieter, "Living It Out. Liberated through Submission? The Worthy Woman's Conference as a Case Study of Formenism," Journal of Feminist Studies in Religion 26 (2010): 141-151.

33 lbid, 148-151.

34 Ibid, 151

35 Fuambai S. Ahmadu and Richard A. Shweder, "Disputing the Myth of the Sexual Dysfunction of Circumcised Women: An Interview with Fuambai S. Ahmadu by Richard A. Shweder," Anthropology Today 25 (2009): 14-17.

36 David Hayes, "Cascade Training and Teachers' Professional Development," ELT Journal 54 (2000): 135- 145.

37 Rebecca A. Orfaly et al., "Train-the-trainer as an Educational Model in Public Health Preparedness," Journal of Public Health Management Practice (2005): S123-S127.

38 lbid, S124.

39 Ibid, S124. Hayes, "Cascade Training," 137.

40 Ibid, 137.

41 Nancy A. Neef, "Research on Training Trainers in Program Implementation: An Introduction and Future Directions," Journal of Applied Behavior Analysis 28 (1995): 297-299.

42 Orfaly et al., "Train-the-trainer," S124.

43 Hayes, "Cascade Training," 138.

44 Ellen J. Hahn et al., "Efficacy of Training and Fidelity of Implementation of the Life Skills Training Program," Journal of School Health 72 (2002): 282-287.

45 Orfaly et al., "Train-the-trainer," S124, S126.

46 United Nations, "Goal 5: Achieve Gender Equality and Empower All Women and Girls," n.p.

Cited 13 June 2017. Online: http://www.un.org/sustainabledevelopment/gender-equality/ 


\section{LIST OF CONTRIBUTORS

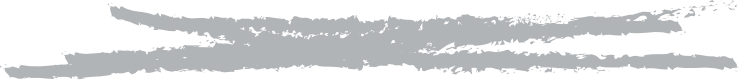

Prof. Cheryl B. Anderson is Professor of Old Testament at Garrett-Evangelical Theological Seminary in Evanston, Illinois, and an ordained elder in The United Methodist Church (Baltimore-Washington Conference). She earned her doctoral degree from Vanderbilt University and earlier in her career, she practised law in Washington, D.C. for nearly ten years. Her current research interests involve contextual and liberationist readings of Scripture in the age of HIV and AIDS. Her publications include two books: Women, Ideology, and Violence: Critical Theory and the Construction of Gender in the Book of the Covenant and the Deuteronomic Law (T \& T Clark, 2004), and Ancient Laws and Contemporary Controversies: The Need for Inclusive Biblical Interpretation (Oxford University Press, 2009).

Michelle BoonzaAier is a minister of the Dutch Reformed Church. She completed the MTh Gender and Health at Stellenbosch University in 2017 with the research assignment titled "Creating Transformative Spaces through Dialogue: Partnership between Inclusive and Affirming Ministries and the Faculty of Theology at The University of Stellenbosch". Michelle works for Inclusive Affirming Ministries (IAM), an LGBTI advocacy organisation. IAM works with faith communities in Africa that are welcoming and affirming so that LGBTI people can participate fully and be strengthened in their spiritual, psychological and sexual identity as human beings.

Prof. L. Juliana Claassens is Professor of Old Testament and Chair of the Department of Old and New Testament at the Faculty of Theology, Stellenbosch University. She moreover serves as the Head of the Gender Unit at the Faculty of Theology. Her most recent book, Claiming Her Dignity: Female Resistance in the Old Testament, was published with Liturgical Press (2016). She is also the author of Mourner, Mother, Midwife: Reimagining God's Liberating Presence (Westminster John Knox, 2012) and The God who Provides: Biblical Images of Divine Nourishment (Abingdon, 2004).

Prof. Pumla Gobodo-Madikizela is Professor and Research Chair for Historical Trauma and Transformation at the Faculty of Arts and Social Sciences, Stellenbosch University. Her critically acclaimed book, A Human Being Died that Night: A South African Story of Forgiveness (2003/2004), explores the interweaving of guilt, shame and remorse on the one hand, and trauma and forgiveness on the other. The book won the Christopher Award in the United States and the Alan Paton Prize in South Africa. It has been published seven times, including translations in Dutch, German, Italian and Korean. She has co-edited the following volumes: Memory, Narrative and Forgiveness: Perspectives on the Unfinished Journeys of 
the Past (2009) and A Reflexive Inquiry into Gender Research: Towards a New Paradigm of Knowledge Production (2015). She is also the editor of Breaking Intergenerational Cycles of Repetition: A Global Dialogue on Historical Trauma and Memory (2016); and a co-author of Narrating our Healing: Perspectives on Healing Trauma (2007).

Prof. Beverley Haddad is Senior Research Associate at the School Religion, Philosophy and Classics, University of KwaZulu-Natal. She is also an ordained priest in the Anglican Church of Southern Africa and a member of the Circle of Concerned African Women Theologians. She has published widely in the field of HIV and AIDS, gender and development, and the role of the church in social transformation and is the editor of the landmark volume, Religion and HIV and AIDS: Charting the Terrain (Pietermaritzburg, UKZN Press, 2011).

Dr Elisabet le Roux is Research Director at the interdisciplinary Unit for Religion and Development Research at Stellenbosch University in South Africa. She is a sociologist working within the field of faith and development, mainly within the Global South. Doing research internationally for governments and global faith-based organisations, she has a particular interest in the intersection between religion and sexual violence. Her work internationally includes the study of faith community responses to developmental issues in conflict-affected settings, patriarchy within faith communities and interfaith peace and conflict.

Dr Funlola O. Olojede is a researcher with the Gender Unit of the Faculty of Theology, Stellenbosch University. A linguist by training, she later obtained her doctoral degree in Old Testament from Stellenbosch University, South Africa. Her research focus includes Gender and Feminist Hermeneutics, Old Testament Studies, Wisdom Literature and African Biblical Interpretation. Some of her writings are available at https://www.researchgate.net/profile/ Funlola_Olojede/contributions.

Dr Selina Palm is Senior Researcher at the interdisciplinary Unit for Religion and Development Research at Stellenbosch University in South Africa. Her research focuses on the intersections between religion and social violence. She delivers faith and development research internationally for a range of organisations and holds a $\mathrm{PhD}$ in Theology and Development, with master's degrees in human rights and in systematic theology. Her work explores the links between human rights and religion in African contexts, the role of hope in social transformation and feminist approaches to sex-work. She is also a lay church leader and a theology lecturer developing creative youth pedagogies for transformation.

Prof. Charlene van der Walt has until recently been appointed in the Department of Old and New Testament at the Faculty of Theology at Stellenbosch University as the Research and Programme Coordinator of the Gender Unit. Her monograph Toward a Communal Reading of 2 Samuel 13: Power and Ideology within the Intercultural Bible Reading Process was published in 2014 as the second volume in the new Intercultural Biblical Hermeneutics Series (Elkhart, IN: AMBS). In August 2017, Charlene relocated to the University of 
KwaZulu-Natal in order to take up an Associate Professor position in Gender and Religion within the School of Religion, Philosophy and Classics. Charlene also serves as the African Coordinator for the Network SRHR.

Renate van der Westhuizen is a principal at Apex High School, a new no-fee parallelmedium public high school. She completed her Master's in Theology with the focus on Gender and Health in March 2016 at the Faculty of Theology, Stellenbosch University and is currently enrolled in a $\mathrm{PhD}$ programme at the University of the Western Cape with a focus on rape culture in the South African educational system.

DR TANYA VAN WYK is a senior lecturer in Systematic Theology, Spirituality and Ethics at the Faculty of Theology and Religion, University of Pretoria. Her PhD thesis (2013) was titled "Church as Heterotopian Space: A Trinitarian Ecclesiology for the Third Millennium." Her research foci include political theology, feminist theology and Trinitarian theology. She is an ordained minister of the Netherdutch Reformed Church (NRCA).

Prof. Gerald O. West is Professor of Old Testament/Hebrew Bible and African Biblical Hermeneutics in the School of Religion, Philosophy and Classics at the University of KwaZulu-Natal, South Africa. He is also Director of the Ujamaa Centre for Community Development and Research, a project in which socially engaged biblical scholars and ordinary African readers of the Bible from poor, working-class and marginalised communities collaborate for social transformation. His most recent publication is The Stolen Bible: From Tool of Imperialism to African Icon (Leiden and Pietermaritzburg: Brill and Cluster Publications, 2016). 